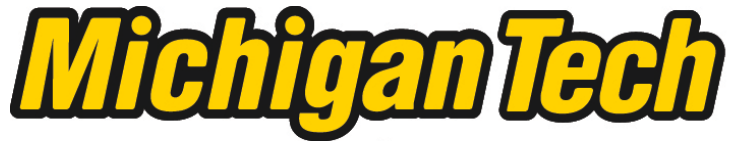 \\ Michigan Technological University Create the Future Digital Commons @ Michigan Tech
}

2015

\section{BIOGEOCHEMICAL CYCLING IN LAKE SUPERIOR TRIBUTARIES: SEASONALITY, QUANTITY AND QUALITY OF EXPORT}

Ashley Anne Coble

Michigan Technological University

Follow this and additional works at: https://digitalcommons.mtu.edu/etds

Part of the Biogeochemistry Commons, and the Ecology and Evolutionary Biology Commons Copyright 2015 Ashley Anne Coble

\section{Recommended Citation}

Coble, Ashley Anne, "BIOGEOCHEMICAL CYCLING IN LAKE SUPERIOR TRIBUTARIES: SEASONALITY, QUANTITY AND QUALITY OF EXPORT", Dissertation, Michigan Technological University, 2015.

https://doi.org/10.37099/mtu.dc.etds/965

Follow this and additional works at: https://digitalcommons.mtu.edu/etds

Part of the Biogeochemistry Commons, and the Ecology and Evolutionary Biology Commons 
BIOGEOCHEMICAL CYCLING IN LAKE SUPERIOR TRIBUTARIES: SEASONALITY, QUANTITY AND QUALITY OF EXPORT

\author{
By \\ Ashley Anne Coble \\ A DISSERTATION \\ Submitted in partial fulfillment of the requirements for the degree of \\ DOCTOR OF PHILOSOPHY \\ In Biological Sciences
}

MICHIGAN TECHNOLOGICAL UNIVERSITY

2015

(C)2015 Ashley A. Coble 
This dissertation has been approved in partial fulfillment of the requirements for the Degree of DOCTOR OF PHILOSOPHY in Biological Sciences

Department of Biological Sciences

Dissertation Advisor: Amy M. Marcarelli, Ph.D.

Committee Member: Casey J. Huckins, Ph.D.

Committee Member: Evan S. Kane, Ph.D.

Committee Member: Veronica L. Webster, Ph.D.

Department Chair: Chandrashekhar P. Joshi, Ph.D. 


\section{Table of Contents}

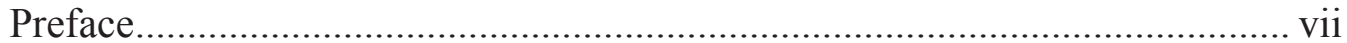

Acknowledgements ................................................................................ viii

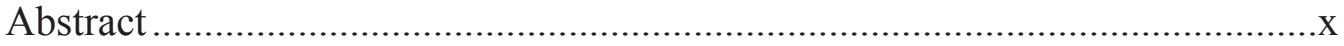

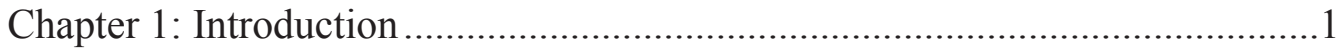

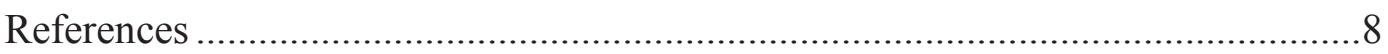

Chapter 2: Nutrient limitation of dissolved organic carbon mineralization in a Lake

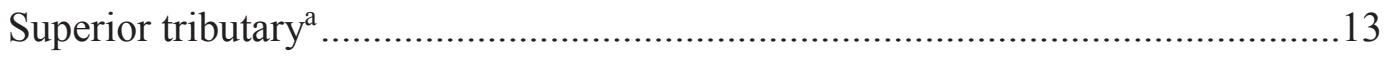

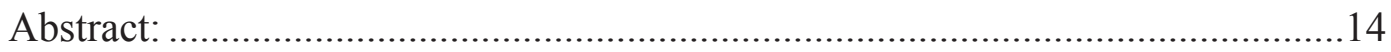

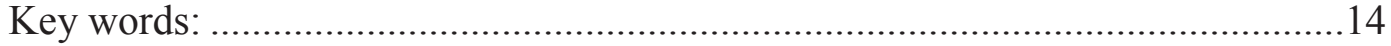

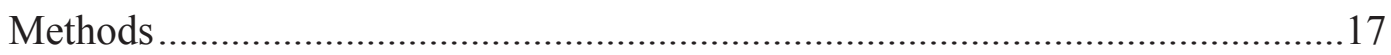

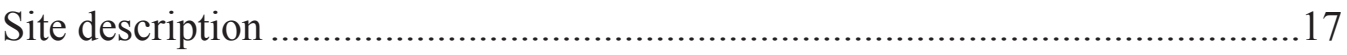

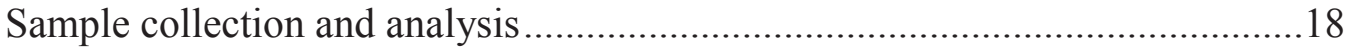

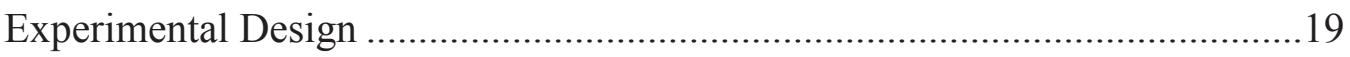

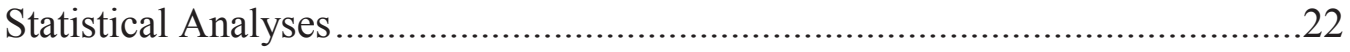

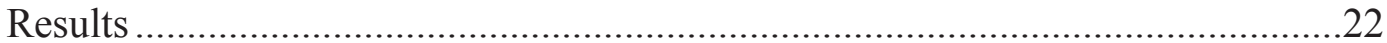

Nutrient amendments and microbial $\mathrm{CO}_{2}$ production over time .....................22

Temporal variability of biodegradable DOC \& stream conditions ...................24

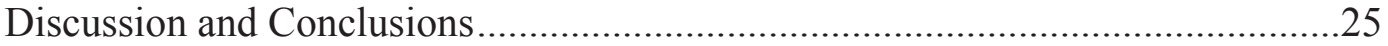

$\mathrm{NH}_{4}$ and labile $\mathrm{C}$ amendments stimulate DOC mineralization rates.................25

Comparison of \%BDOC estimates to other studies.......................................27

Potential for $\%$ BDOC export to Lake Superior .............................................28

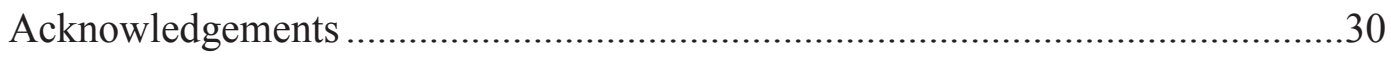

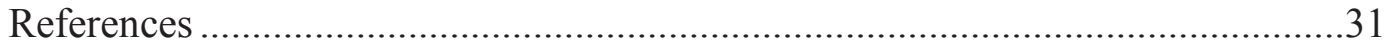

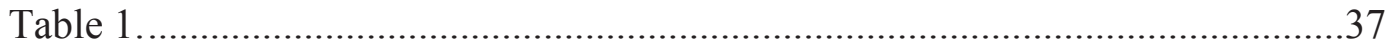

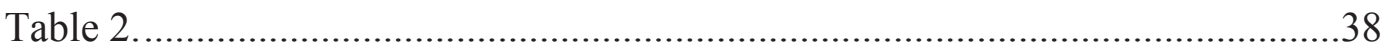

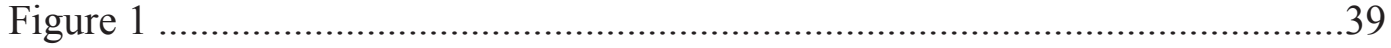

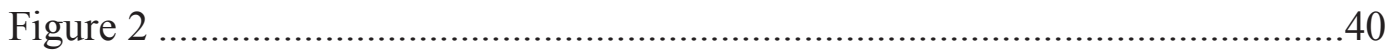


Chapter 3: Seasonal patterns of dissolved organic matter biodegradability are similar across three northern temperate rivers ${ }^{\mathrm{a}}$

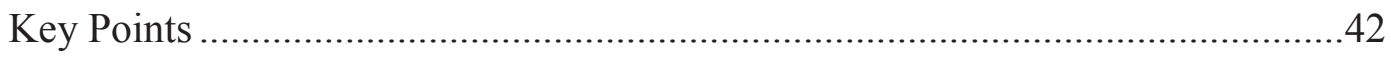

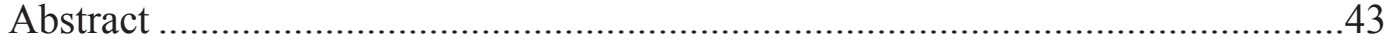

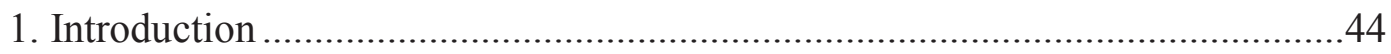

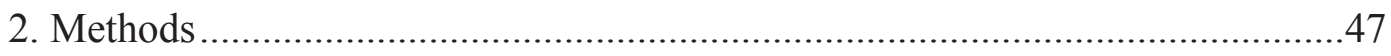

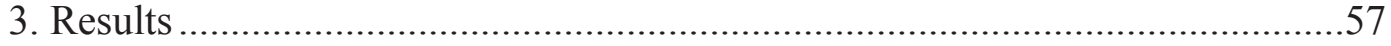

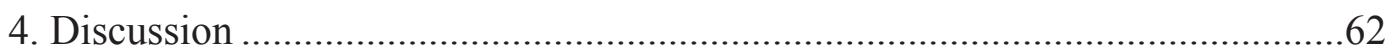

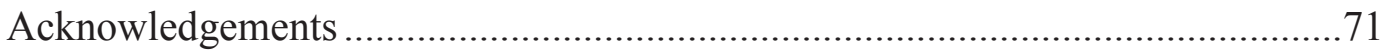

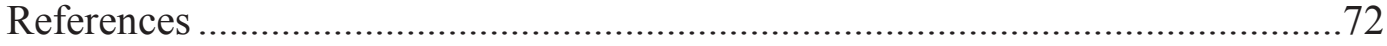

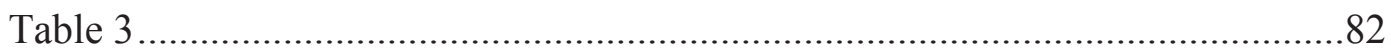

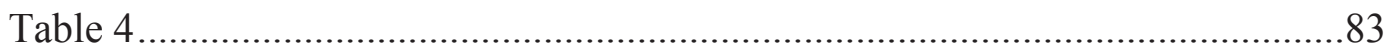

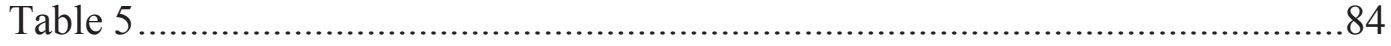

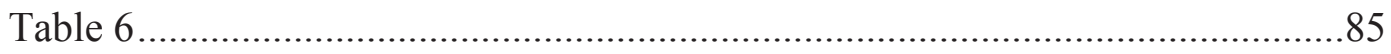

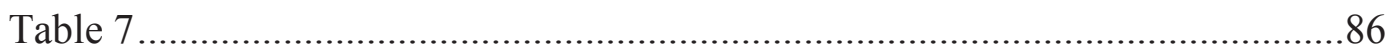

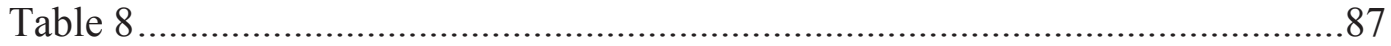

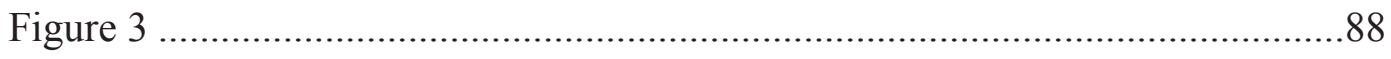

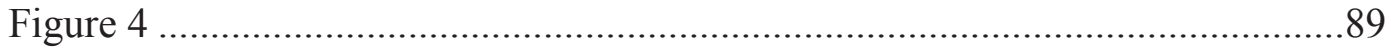

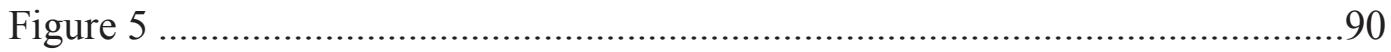

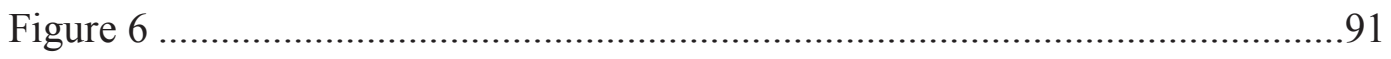

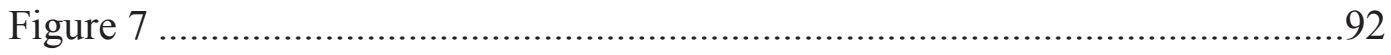

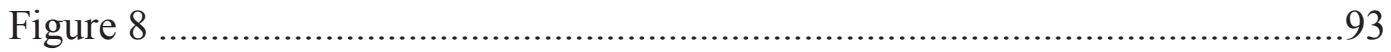

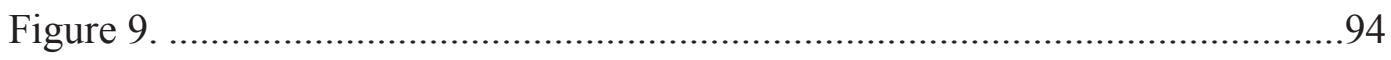

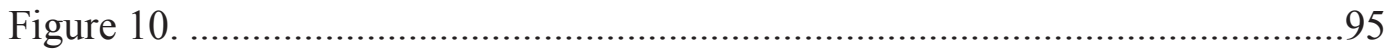

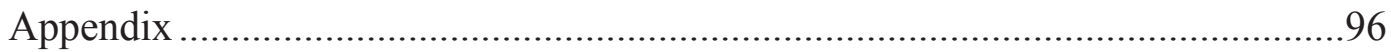

Chapter 4: Linkages among watershed characteristics, DOM composition, and uptake of nitrogen, phosphorus, and carbon in rivers ${ }^{\mathrm{a}}$..................................... 103

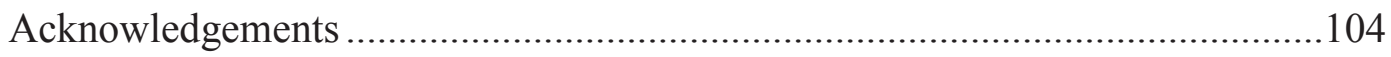

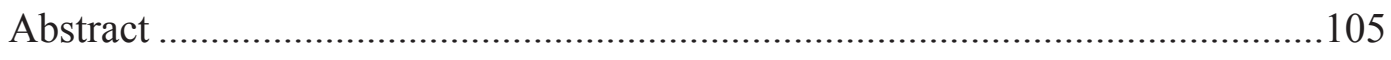

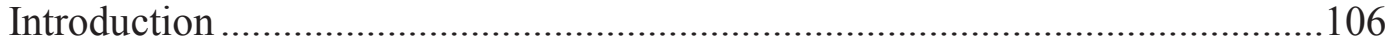

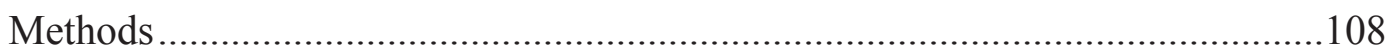




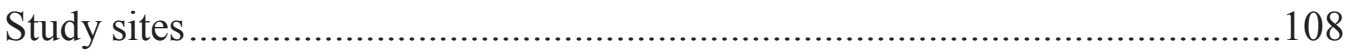

Watershed characteristics and stream chemistry ………………………...........109

Dissolved organic matter character ................................................................111

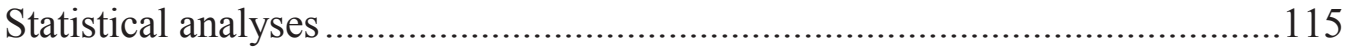

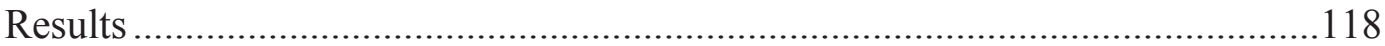

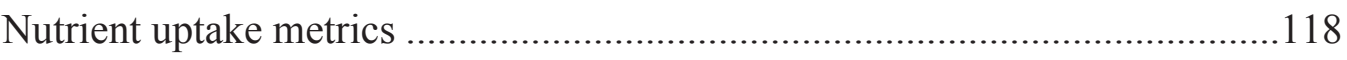

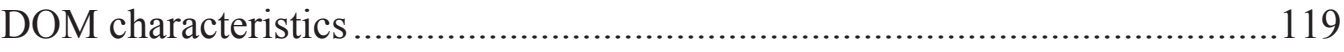

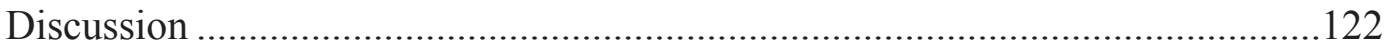

Drivers of nutrient uptake and linkages between C, N, and P.........................123

Variability in nutrient uptake among watersheds and years.............................126

Export of solutes to downstream ecosystems ....................................................128

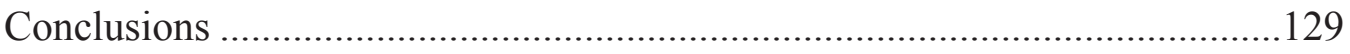

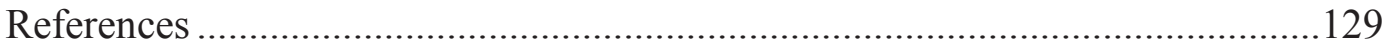

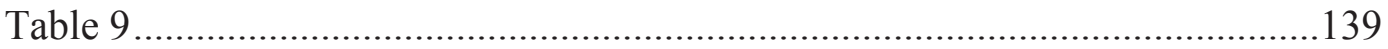

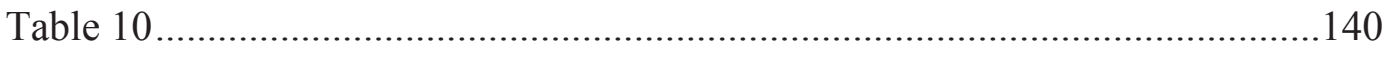

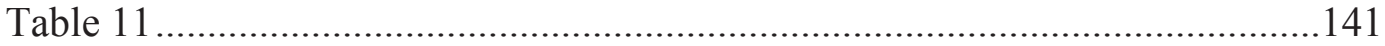

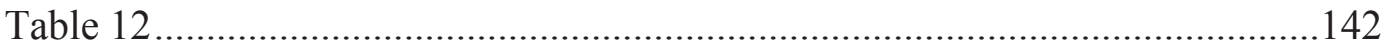

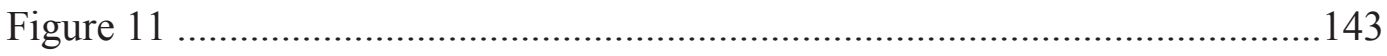

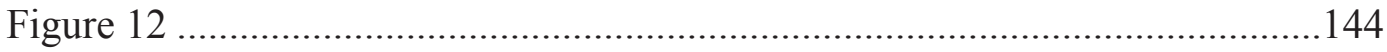

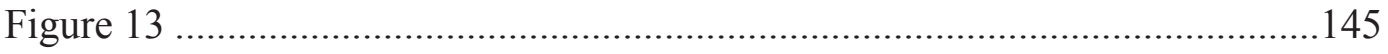

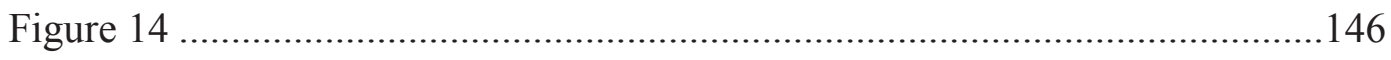

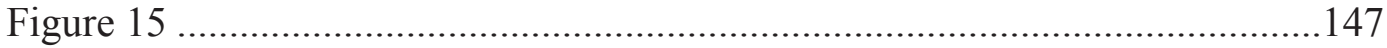

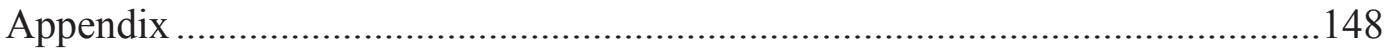

Chapter 5: Year-round measurements of nutrient uptake in a snowmelt-driven

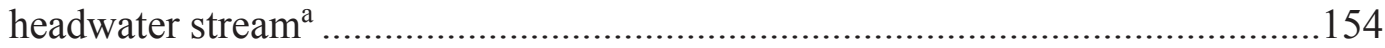

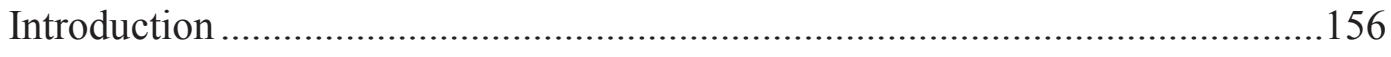

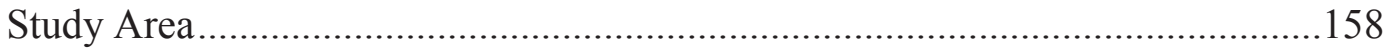

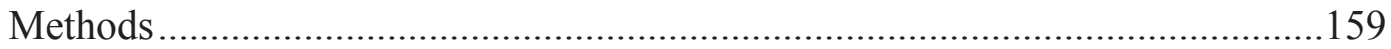

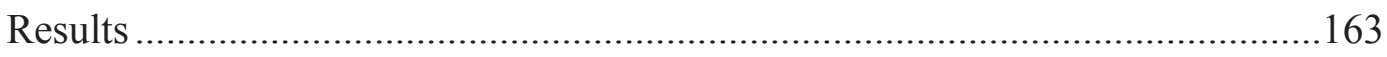

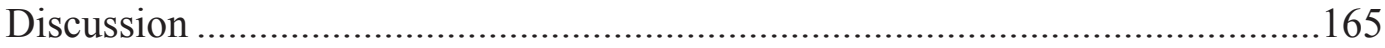




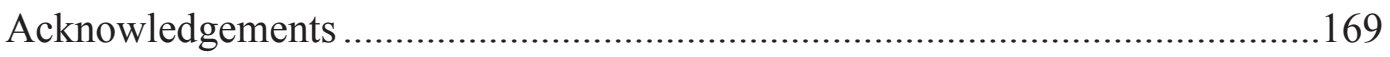

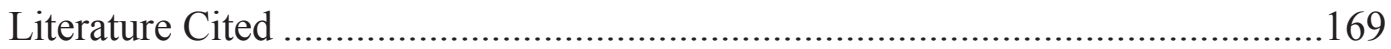

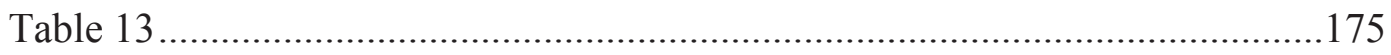

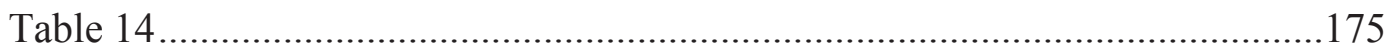

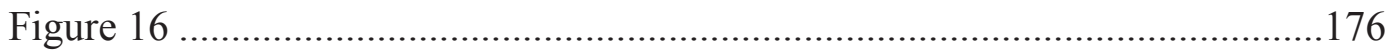

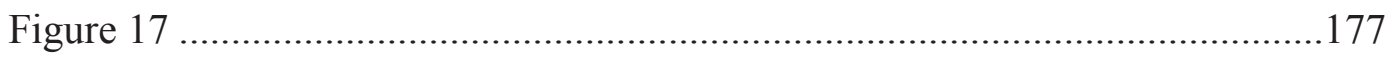

Appendix A: Nutrient uptake measurements ............................................. 178

Appendix B: Chlorophyll a and ash-free dry mass ........................................ 184

Appendix C: Leaf area index and diffuse non-interceptance ............................186

Appendix D: Dissolved organic matter characterization ................................. 187

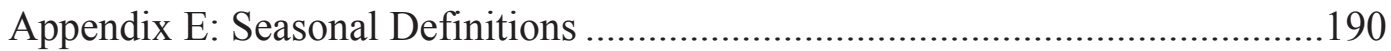




\section{Preface}

This dissertation has been written as a collection of four articles, which will be submitted for publication in scientific journals. For all chapters, I led all aspects of the research (study design, field data collection, laboratory analysis, data analysis, and interpretation of the data) and am the primary author. Chapter 2 is in consideration for publication in the Journal of Great Lakes Research and was written in collaboration with Amy M. Marcarelli and Evan S. Kane. Drs. Marcarelli and Kane contributed to study design, acquisition of funding, data analysis, and writing of the manuscript. Chapter 3 will be submitted to the Journal of Geophysical Research and was written with coauthors Amy M. Marcarelli, Evan S. Kane, Robert Stottlemyer, and David Toczydlowski. Drs. Marcarelli and Kane contributed to study design, acquisition of funding, and writing of the manuscript. Dr. Stottlemyer and Mr. Toczydlowski contributed long-term monitoring data and assisted with editing of the manuscript. Chapter 4 will be submitted to Limnnology and Oceanography and was written in collaboration with Amy M. Marcarelli, Evan S. Kane, and Casey J. Huckins. Drs. Marcarelli, Kane, and Huckins assisted with acquisition of funding, study design, data analysis and writing of the manuscript. Chapter 5 has been prepared as a report for Ecology and was written in collaboration with Amy M. Marcarelli and Evan S. Kane, both of whom contributed to the study design, acquisition of funding and manuscript writing. 


\section{Acknowledgements}

Funding for this research was provided by: Huron Mountain Wildlife Foundation, Michigan Technological University's Center for Water and Society, Michigan Technological University's Ecosystem Science Center, National Science Foundation GK12 Global Watershed program (award DGE-0841073), Michigan Technological University’s Research Excellence Fund, NASA Michigan Space Grant Consortium, University of Michigan Water Center with funds from the Fred A. and Barbara M. Erb Family Foundation, and USDA McIntire-Stennis Fund

To my advisor, Dr. Amy Marcarelli, I would like to express my gratitude for the countless hours she has spent providing advice and support; without her substantial contributions and expertise this work would not have been possible. I greatly appreciate the assistance of Dr. Evan Kane for his support, guidance, and expertise that were critical in initiating and carrying out this research. I would like to thank Dr. Casey Huckins for his guidance in identifying research sites, collaboration on multiple projects, and providing ideas to initiate this research. I also would like to thank Dr. Veronica Webster for lending her time and expertise to improve this body of research.

Completion of this research required field and laboratory assistance from numerous researchers whom I would like to thank: J. Bontrager, B. Borowitz, A.P. Coble, E. Collins, B. Danhoff, J. Ebel, J. Eikenberry, D. Fenlon, K. Heiden, J. Kiiskila, T. Matthys, K. Meingast, A. Mills, J. Olson, J. Ortiz, K. Price, R. Van Goethem, A. Struthers, and T. Veverica. A special thanks to those who braved the extremely cold and snowy Upper Peninsula weather to collect field data throughout the winter: J. Bontrager, E. Collins, and K. Heiden. Thank you to M. Cavaleri for providing use of field 
equipment. Thanks to R. Stottlemyer and D. Toczydlowski for their continued monitoring of watershed biogeochemistry, sharing of long-term monitoring data, and support, all of which made my research efforts at Calumet watershed possible.

I would like to acknowledge my family, whose support was critical to my successful completion of this degree: To my incredibly amazing and supportive husband, Adam Coble, his scientific expertise has been invaluable to my work but his encouragement and support has allowed me to achieve more than I had thought possible. To our son, whom we love dearly; it is with eager anticipation of his arrival that has provided me with the necessary motivation to write my dissertation. To my parents for their encouragement and support that have allowed me to pursue my passion. 


\begin{abstract}
Seasonal and spatial variability in environmental factors may affect dissolved organic matter composition and nutrient transformation and retention in streams. The objective of this research was to quantify and describe seasonality, quantity, and quality of nutrient processing and export of ammonium $\left(\mathrm{NH}_{4}\right)$, soluble reactive phosphate (SRP), and dissolved organic carbon (DOC) into Lake Superior through intensive study in a small $1^{\text {st }}$ order watershed coupled with snapshot measurements across 12 tributaries that varied in size, location, and wetland coverage. Our results suggest biodegradable $\mathrm{C}$ is exported from a small headwater stream year-round and that DOC mineralization rates can be stimulated by additions of $\mathrm{NH}_{4}$ and labile $\mathrm{C}$ (Chapter 2$)$. We found that biodegradable DOC varied synchronously among 3 rivers that varied in size by three orders of magnitude. Furthermore, these rivers exported 9 to $17 \%$ of annual DOC in biodegradable form, which may then fuel biological activity in nearshore zones of Lake Superior. Modeling of historical loads of DOC suggests that spring loads of DOC have increased and fall loads have decreased over a 26 year period, but annual loads have not (Chapter 3). Across eleven tributaries variability in $\mathrm{NH}_{4}$ uptake velocity was explained by watershed area, discharge, and fluorescence index of DOC (indicator of microbial and terrestrial sources; Chapter 4). Temporally detailed measurements (every 2 to 4 weeks for 3 years) of nutrient uptake in a small headwater stream indicated light availability, algal and periphyton biomass, solute concentrations, and $\mathrm{pH}$ were important predictors of $\mathrm{NH}_{4}$ uptake velocity (Chapter 5). We found a similar magnitude of $\mathrm{NH}_{4}$ uptake velocity during winter and summer measurements while SRP uptake velocity was greater in summer than winter (Chapter 5). Overall the greatest uptake velocities were observed in
\end{abstract}


spring and fall for $\mathrm{NH}_{4}$, in spring for SRP and in fall for DOC (Chapter 5). Collectively, this research demonstrates the temporally dynamic nature of biodegradable carbon and nutrient uptake, the tight coupling of $\mathrm{C}$ and $\mathrm{N}$ cycling, and the role of DOM composition in stream nutrient uptake in northern temperate forested streams. 


\section{Chapter 1: Introduction}

In aquatic ecosystems, dissolved organic carbon (DOC) plays an integral role in biogeochemical cycling because it provides an energy source for aquatic organisms, alters $\mathrm{pH}$, affects light penetration, and binds elements (e.g., Maranger and Pullin 2003; Laudon et al. 2004). Global estimates reveal terrestrial ecosystems deliver at least $1.9 \mathrm{Pg}$

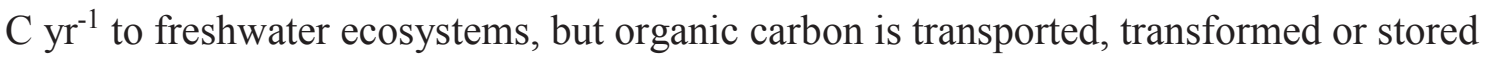
in streams, rivers and lakes to the extent that only half of this amount of $\mathrm{C}$ is ultimately delivered to the ocean (Cole et al. 2007). A significant pathway of C loss, which was not originally incorporated into Cole et al. (2007)'s C budget, also occurs as carbon dioxide $\left(\mathrm{CO}_{2}\right)$ evasion from streams and rivers (Buffam et al. 2011; Butman and Raymond 2011), with the greatest $\mathrm{CO}_{2}$ evasion rates occurring in the smallest $\left(1^{\text {st }}\right.$ order) streams (Butman and Raymond 2011). Small streams have also been shown to have a disproportionate role in nutrient cycling of nitrogen $(\mathrm{N})$ compared to larger tributaries (Alexander et al. 2000; Peterson et al. 2001), and the smallest streams alone comprise $48 \%$ of the total stream length in a typical stream network due to their high density (Leopold et al. 1964). To estimate nutrient export from streams to downstream ecosystems it is important to incorporate a range of stream sizes to account for variability in input and in-stream processing rates.

$\mathrm{C}, \mathrm{N}$, and phosphorus $(\mathrm{P})$ provide essential nutrients and energy sources to aquatic organisms, and among these elements, researchers have previously demonstrated the tight relationship between $\mathrm{C}$ and $\mathrm{N}$ cycling in streams (Bernhardt and Likens 2002; Sobczak et al. 2003; Johnson et al. 2009). DOC availability can increase the assimilative demand for 
nitrogen, as has been demonstrated by nutrient injections into streams (e.g., Johnson et al. 2009) and laboratory incubation experiments (e.g., Sobczak et al. 2003). For example, Sobczak et al. (2003) incubated stream water from Neversink River and found that an increase in bioavailable DOC increased stream $\mathrm{N}$ retention. Any natural variations in seasonal DOC availability or composition will likely affect stream $\mathrm{N}$ retention, as well as uptake of DOC.

Autochthonous (aquatic primary production) and allochthonous (terrestrial organic matter) inputs provide DOC to streams, and the variability of these inputs affects stream DOC concentrations and chemical composition (Bertilsson and Jones 2003; McKnight et al. 2003; Mulholland 2003). Dissolved organic matter (DOM), from which DOC is derived, is a chemically heterogeneous compound. In a typical river fulvic acids comprise the greatest percentage of DOM, but humic acids, transphilic acids, high and low molecular weight acids, neutrals, and bases each comprise small fractions of the remaining portion of DOM (Thurman 1985). DOC concentrations from Lake Superior tributaries range from 2.8 to $36 \mathrm{mg} \mathrm{L}^{-1}$ (Maier and Swain 1978; Back et al. 2002; Urban et al. 2005) and are positively correlated with physicochemical properties (e.g. molecular weight, spectral indices), which are indicators of bioavailability and DOM transformations (Frost et al. 2006). The percent of wetlands in a watershed is an important predictor of surface water DOC concentrations (Mulholland 2003) and has also been positively correlated with DOM physicochemical properties (Frost et al. 2006). Due to the prevalence of wetlands and variability of their coverage within the Great Lakes region, spatial variability in DOC concentrations and composition likely exists among Great Lakes tributaries. 
Seasonal changes in environmental factors (e.g., light availability, temperature, or nutrient inputs) may affect nutrient transformation and retention (e.g., Mulholland et al. 1985; Hoellein et al. 2007). However, few studies have examined in-stream processing in the winter, particularly in regions where snow represents a significant amount of the annual precipitation. Several studies have found high nutrient uptake velocities in spring for ammonium $\left(\mathrm{NH}_{4}\right)\left(\right.$ Hoellein et al. 2007, Johnson et al. 2009), nitrate $\left(\mathrm{NO}_{3}\right)($ Hoellein et al. 2007, Hall et al. 2009), and soluble reactive phosphorus (SRP) (Hoellein et al. 2007). A previous study conducted in southwest Michigan found stream uptake of labile DOC did not vary seasonally among spring, summer, or fall seasons, but found that DOC uptake can be as high as $\mathrm{NH}_{4}$ uptake (Johnson et al. 2009). Of these studies, none were able to collect continuous measurements throughout the winter. For example, Hoellein et al. (2007) was unable to measure nutrient uptake from January through March, due to excessive snowpack limiting site accessibility. Without an understanding of how instream biogeochemical cycling varies year-round in snow-dominated regions it is uncertain how climate change will affect nutrient export to downstream ecosystems.

Climate change is expected to alter temperature and precipitation globally, and may have pronounced effects on terrestrial and aquatic ecosystems in the Great Lakes region. Global climate predictions indicate that in regions currently receiving snow, warming will alter stream flow such that winter flows will increase and summer flows will decrease (IPCC 2007). Warming air temperatures have already been observed in long-term monitoring records in the Great Lakes region (Schindler et al. 1997; Stottlemyer and Toczdlowski 2006; NOAA 2012). At Calumet watershed, a $1^{\text {st }}$ order tributary of Lake Superior, monitoring over a 30-year period has identified a decreased 
duration of snowpack, increased stream spring DOC and total dissolved $\mathrm{N}$ export, and increased ratio of winter runoff to precipitation with time (Stottlemyer and Toczdlowski 2006; Stottlemyer and Toczdlowski 2011). A global analysis of extreme temperature collected over a similar 30-year period (1981-2010) compared with a reference (19511980) concluded dramatic increases in seasonal mean temperature anomalies were due to climate change (Hansen et al. 2012). If observed regional trends continue, we could expect altered nutrient export, and magnitude and timing of discharge from streams in the Great Lakes region, which would have consequences for nutrient budgets of downstream ecosystems. For example, reduced duration of snowpack may result in frozen soils (e.g., Groffman et al. 2001), which would prevent precipitation or runoff from infiltrating the soil (i.e., reduce soil microbial processing) prior to entering the stream channel. Determining which environmental factors drive seasonal patterns of stream nutrient cycling and how biodegradable DOC loads have changed over the past 30 years will improve our ability to identify potential impacts of climate change on freshwater aquatic ecosystems in the Great Lakes region.

My dissertation research sought to improve our understanding of temporal and spatial variability of in-stream N, P, and C dynamics among Lake Superior tributaries. In the first study (Chapter 2) we determined if DOC mineralization rates were limited by availability of $\mathrm{N}$ or labile $\mathrm{C}$ in a small tributary of Lake Superior by conducting experimental additions of $\mathrm{N}$ and $\mathrm{C}$ to stream water in 28 day incubations and measuring DOC mineralization rates on four dates corresponding to seasons. We found that DOC mineralization rates were stimulated by $\mathrm{NH}_{4}$ on 3 of the 4 dates (summer, fall and spring but not winter) and by labile $\mathrm{C}$ on all 4 dates, and that biodegradable $\mathrm{DOC}$ was greater in 
spring than fall and winter, but did not differ from spring. These results suggest that biodegradable $\mathrm{C}$ is exported from this small headwater stream year-round and that DOC mineralization rates can be stimulated by additions of $\mathrm{NH}_{4}$ and labile $\mathrm{C}$.

In the second study we examined whether biodegradability of DOC varies temporally in northern temperate watersheds by measuring BDOC via incubation assays on eleven dates throughout a one-year period in three tributaries that vary in size by three orders of magnitude (Chapter 3). We found that BDOC was seasonally synchronous across these watersheds, and that DOC composition varied the most among tributaries in summer, but was remarkably similar during fall, spring and winter. We further quantified that these rivers export 9 to $17 \%$ of annual DOC in biodegradable form. Modeling of historical loads of DOC does not suggest exports have changed on an annual basis to date, but does suggest that spring loads of DOC have increased and fall loads have decreased over the past 26 years. Together, these results suggest that future hydrologic and climatic changes may alter export of BDOC if they change the timing of major runoff events like snowmelt and storms.

In the third study, we aimed to identify important drivers of $\mathrm{N}, \mathrm{P}$, and $\mathrm{C}$ uptake by measuring in-stream nutrient spiraling, DOM composition, and watershed characteristics across eleven Lake Superior tributaries (Chapter 4). We found watershed area, discharge, and fluorescence index were all highly influential variables explaining variability in $\mathrm{NH}_{4}$ uptake velocity across sites, and that DOM composition and DOC concentration may be important predictors of nutrient uptake in streams, but they are often overlooked in studies of nutrient spiraling. Fluorescence index identifies the source of fulvic acids (microbial versus terrestrial; McKnight et al. 2001). Furthermore, our measurements 
suggest that DOC and SRP are likely exported from many Lake Superior tributaries without measureable uptake during summer baseflow, and may be important nutrient and energy sources to the near-shore region of Lake Superior.

In the fourth study, we aimed to quantify how nutrient uptake varies temporally and identify environmental drivers of this temporal variability by measuring in-stream nutrient spiraling of $\mathrm{N}, \mathrm{P}$, and $\mathrm{C}$ in a small first order tributary in fine temporal detail (2-4 week intervals over a 3 year period) (Chapter 5). We found similar magnitude of $\mathrm{NH}_{4}$ uptake velocity during winter and summer, while SRP uptake velocity was greater in summer than winter. Overall the greatest uptake velocities were observed in spring and fall for $\mathrm{NH}_{4}$, in spring for SRP and in fall for DOC. We identified that light availability, biofilm chlorophyll a and ash-free dry mass, conductivity, $\mathrm{DOC}, \mathrm{NH}_{4}$, and $\mathrm{pH}$ were important predictors of $\mathrm{NH}_{4}$ uptake velocity. Our results suggest that any future alteration to the timing of these important variables could alter nutrient export to downstream ecosystems.

Collectively these four research chapters reveal that concentrations of biodegradable $\mathrm{C}$ and rates of nutrient uptake were temporally dynamic in Lake Superior tributaries, that the cycling of $\mathrm{C}$ and $\mathrm{N}$ were tightly coupled in northern temperate rivers, and that dissolved organic matter composition can control rates of in-stream nutrient uptake. Furthermore, by investigating drivers of nutrient uptake we found that temporally detailed, year-round measurements revealed different predictors of nutrient uptake than when compared spatially among different tributaries during summer base flow. For example, we found light availability was an important driver on an annual scale within a single stream but not among rivers. Clearly, utilizing a combination of 
spatial and temporal measurements can provide additional insight into mechanisms that control in-stream biogeochemical processes in northern temperate streams. 


\section{References}

Alexander R.B., Smith R.A., and Schwarz G.E. 2000. Effect of stream channel size on the delivery of nitrogen to the Gulf of Mexico. Nature 403:758-761

Back R.C., Hurley J.P., and Rolfhus K.R. 2002. Watershed influences on the transport, fate, and bioavailability of mercury in Lake Superior: field measurements and modeling approaches. Lakes and Reservoirs: Research and Management 7:201206

Bernhardt E.S., and Likens G.E. 2002. Dissolved organic carbon enrichment alters nitrogen dynamics in a forest stream. Ecology 83(6):1689-1700

Bertilsson S., and Jones J.B. Jr. 2003. Supply of dissolved organic matter to aquatic ecosystems: autochthonous sources. In: Aquatic ecosytems interactivity of dissolved organic matter. Editors: Findlay S.E., and Sinsabaugh R.L. Academic Press, San Diego

Buffam I., Turner M.G., Desai A.R., Hanson P.C., Rusaks J.A., Lottig N.R., Stanley E.H., Carpenter S.R. 2011. Integrating aquatic and terrestrial components to construct a complete carbon budget for a north temperate lake district. Global Change Biology 17:1193-1211, doi:10.1111/j.1365-2486.2010.02313.x

Butman D., and Raymond P.A. 2011. Significant efflux of carbon dioxide from streams and rivers in the United States. Nature Geoscience 4:829-842

Cole J.J., Prairie Y.T., Caraco N.F., McDowell W.H., Trnvik L.J., Striegl R.G., Duarte C.M., Kortelainen P., Downing J.A., Middelburg J.J., and Melack J. 2007. Plumbing the Global Carbon cycle: integrating inland waters in to the terrestrial carbon budget. Ecosystems 10:171-184, doi:10.1007/s10021-006-9013-8 
Frost P.C., Larson J.H., Johnston C.A., Young K.C., Maurice P.A., Lamberti G.A., and Bridgham S.D. 2006. Landscape predictors of stream dissolved organic matter concentration and physicochemistry in a Lake Superior river watershed. Aquatic Science 68:40-51

Groffman P.M., Driscoll C.T., Fahey T.J., Hardy J.P., Fitzhugh R.D., and Tierney G.L. 2001. Colder soils in a warmer world: a snow manipulation study in a northern hardwood forest ecosystem. Biogeochemistry 56(2): 135-150

Hall R.O., Baker M.A., Arp C.D., and Koch B.J. 2009. Hydrologic control of nitrogen removal, storage, and export in a mountain stream. Limnology and Oceanography 54: 2128-2142.

Hansen, J., Sato, M., and Ruedy, R. 2012. Perception of climate change. Proceedings of the National Academy of Sciences 109(37), E2415-E2423, www.pnas.org/cgi/doi/10.1073/pnas.1205276109

Hoellein T.J., Tank J.L., Rosi-Marshall E.J., Entrekin S.A., and Lamberti G.A.2007. Controls on spatial and temporal variation of nutrient uptake in three Michigan headwater streams. Limnology and Oceanography 52(5):1964-1977

Intergovernmental Panel on Climate Change. 2007. Climate Change 2007: Impacts, Adaptation and Vulnerability. Contribution of Working Group II to the Fourth Assessment Report of the Intergovernmental Panel on Climate Change. M.L. Parry, O.F. Canziani, J.P. Palutikof, P.J. van der Linden, and C.E. Hanson, Eds., Cambridge University Press, Cambridge, UK, 976pp. 
Johnson L.T., Tank J.L, and Arango C.P. 2009. The effect of land use on dissolved organic carbon and nitrogen uptake in streams. Freshwater Biology 54(11):23352350, doi:10.1111/j.1365-2427.2009.02261

Laudon H., Köhler S., and Buffam I. 2004. Seasonal TOC export from seven boreal catchments in northern Sweden. Aquatic Sciences-Research Across Boundaries $66(2): 223-230$

Leopold L.B., Wolman M.G., Miller J.P. 1964, 1992. Fluvial processes in geomorphology, $2^{\text {nd }}$ edition. New York: Dover Publishers 522pp.

Maranger R., and Pullen M.J. 2003. Elemental complexation by dissolved organic matter in lakes: implications for Fe speciation and the bioavailability of Fe and P. In: Aquatic ecosytems interactivity of dissolved organic matter. Editors: Findlay S.E., and Sinsabaugh R.L. Academic Press, San Diego

Maier W.J., and Swain W.R.. 1978. Lake Superior organic carbon budget. Water Resources 12: 403-412

McKnight D.M., Boyer E.W., Westerhoff P.K., Doran P.T., Kulbe T., and Anderson D.T. 2001. Spectrofluorometric characterization of dissolved organic matter for indication of precursor organic material and aromaticity. Limnology and Oceanography 46: 38-48, doi:10.4319/1o.2001.46.1.0038

McKnight D.M., Hood E., and Klapper L. 2003. Trace organic moieties of dissolved organic material in natural waters. In: Aquatic ecosytems interactivity of dissolved organic matter. Editors: Findlay S.E., and Sinsabaugh R.L. Academic Press, San Diego 
Mulholland P.J. 2003. Large-scale patterns in dissolved organic carbon concentration, flux, and sources. In: Aquatic ecosytems interactivity of dissolved organic matter. Editors: Findlay S.E., and Sinsabaugh R.L. Academic Press, San Diego

Mulholland P.J., Newbold J.D., Elwood J.W., and Ferren L.A.1985. Phosphorus spiraling in a woodland stream: seasonal variations. Ecology 66(3)1012-1023

NOAA. 2012. Data from national Climate Data Center. http://www.ncdc.noaa.gov. Accessed on: 8 November 2012

Peterson B.J., Wollheim W.M., Mulholland P.J., Webster J.R., Meyer J.L., Tank J.L., Marti E., Bowden W.B., Valett H.M., Hershey A.E., McDowell W.H., Dodds W.K., Hamilton S.K., Gregory S., Morrall D.D. 2001. Control of nitrogen export from watersheds by headwater streams. Science 292:86-90

Schindler D.W., Curtis P.J., Bayley S.E., Parker B.R., Beaty K.G., and Stainton M.P. 1997. Climate-induced changes in the dissolved organic carbon budgets of boreal lakes. Biogeochemistry 36:9-28

Sobczak W.V., Findlay S., and Dye S. 2003. Relationships between DOC bioavailability and nitrate removal in an upland stream: an experimental approach. Biogeochemistry 62(3): 309-327.

Stottlemyer R., and Toczydlowski D. 2006. Effect of reduced winter precipitation and increased temperature on watershed solute flux, 1988-2002, Northern Michigan. Biogeochemistry 77:409-440, doi 10.1007/s10533-005-1810-1

Stottlemyer R., and Toczydlowski D. 2011. 2010 annual report for the Calumet watershed; trends 1980-2010. Michigan Technological University. 
Thurman E.M. 1985. Geochemistry of soil humic substances. In "Humic Substances in Soil, Sediment and Water: Geochemistry, Isolations, and Characterization" Editors Aiken G.R., McKnight D.M., Weshaw R.L., MacCarthy P. pp. 105-146 Wiley, New York.

Urban N.R., Auer M.T., Green S.A., Lu, X., Apui, D.S., Powell, K.D., Bub, L. 2005. Carbon cycling in Lake Superior. Journal of Geophysical Research 110:C06S90, doi:10.1029/2003JC002230 
Chapter 2: Nutrient limitation of dissolved organic carbon mineralization in a Lake Superior tributary ${ }^{\mathrm{a}}$

Ashley A. Coble ${ }^{1, *}$, Amy M. Marcarelli' ${ }^{1}$ Evan S. Kane ${ }^{2,3}$

${ }^{1}$ Department of Biological Sciences, Michigan Technological University, 1400 Townsend Drive, Houghton, Michigan 49931 USA; Phone: 620200 7696, Fax: 9064873167

${ }^{2}$ School of Forest Resources and Environmental Science, Michigan Technological University, Houghton, Michigan 49931 USA

${ }^{3}$ U.S. Forest Service, Northern Research Station, 410 MacInnes, Houghton, Michigan 49931 USA

*Corresponding author

E-mail addresses: aacoble@mtu.edu (A.A. Coble), ammarcar@mtu.edu (A.M.

Marcarelli), eskane@mtu.edu (E.S. Kane)

${ }^{\mathrm{a}}$ Chapter 2 is currently in review by the Journal of Great Lakes Research 


\begin{abstract}
Dissolved organic carbon (DOC) plays an integral role in the biogeochemical cycles of aquatic ecosystems, and rates of DOC mineralization can be affected by nitrogen $(\mathrm{N})$ availability and carbon $(\mathrm{C})$ quality in the water column. To determine if DOC mineralization rates were limited by availability of $\mathrm{N}$ or labile $\mathrm{C}$ in a small tributary of Lake Superior, we conducted 28-day laboratory experiments where we amended stream water with ammonium $\left(\mathrm{NH}_{4}\right)$ and/or glucose in a full factorial design $(\mathrm{N}, \mathrm{C}, \mathrm{C}+\mathrm{N}$, no amendment). We repeated these experiments on four dates (July, October, January, April), as we expected nutrient limitation to vary with temporal changes in sources of DOC and nutrients. DOC mineralization rates were stimulated by additions of $\mathrm{NH}_{4}$ in three of the four experiments and by glucose in all four experiments, even in October when carbon inputs to the stream via leaf litter were greatest. Mean $\%$ BDOC was greater in July $(40.6 \%, \pm 5.4)$ than October $(10.2 \% \pm 0.9)$ or January $(9.6 \% \pm 10.9)$, but did not differ from April (18.4\% \pm 0.7$)$, which suggests the quality of DOC varies temporally. Our results suggest that biodegradable $\mathrm{C}$ is exported from this forested stream to nearshore Lake Superior throughout the year, but DOC mineralization can be stimulated by additions of both carbon and nitrogen. Nutrient enrichment may alter in-stream processing of DOC in small forested tributary streams, in turn reducing export of high quality DOC to near-shore regions of the Great Lakes, where it fuels microbial production.
\end{abstract}

Key words: biodegradable dissolved organic carbon, tributary stream, nutrient limitation, temporal variability, Lake Superior 
It is well recognized that dissolved organic carbon (DOC) is an important component of biogeochemical cycling in aquatic ecosystems (Sholkovitz, 1976; Buffam et al., 2001; Aiken et al., 2011), but C cycling in freshwaters has only recently emerged as an important, but previously overlooked, component of the global carbon cycle (e.g., Cole et al., 2007). Carbon dioxide $\left(\mathrm{CO}_{2}\right)$ evasion from streams and rivers driven by heterotrophic bacterial decomposition of organic $\mathrm{C}$ is a significant pathway of $\mathrm{C}$ loss (Jonsson et al., 2003; Karlsson et al., 2007; McCallister and del Giorgio, 2008), and among surface waters, the greatest amount of cumulative $\mathrm{CO}_{2}$ evasion occurs from the smallest streams (Butman and Raymond, 2011; Wallin et al., 2013). In turn, bacterial metabolism in streams, including respiration and demand for inorganic nutrients, can be affected by changes in dissolved organic matter (DOM) sources and composition (Findlay, 2003), which vary temporally (e.g., Mulholland and Hill, 1997). Some research suggests that $\mathrm{C}$ quality is positively correlated with DOM or DOC concentrations (Buffam et al., 2001; Frost et al., 2006; Wilson et al., 2013). For example, Wilson et al. (2013) found that the percent of biodegradable DOC (\%BDOC, the fraction of DOC that can be mineralized by heterotrophic microbes within days to months), increased with increasing DOC concentrations in a small temperate stream. Seasonal variability also exerts strong controls over the susceptibility of DOC to photochemical degradation in tributaries of the Great Lakes (MacDonald and Minor, 2013), further affecting DOC composition.

Terrestrial subsidies of $\mathrm{C}$ delivered via rivers and groundwater may supply an important source of C to large lakes (e.g. Lake Michigan, Bidanda and Cotner, 2002; Lake Baikal, Yoshioka et al., 2002), yet our understanding of DOC biodegradability in 
Great Lakes tributaries is limited. For example, of the estimated 0.4 to $0.9 \mathrm{Tg} \mathrm{C}$ exported from tributaries to Lake Superior (Urban et al., 2005), the labile fraction of the tributary DOC pool remains unknown. A recent study modeling Lake Superior C processing relied on estimates of biodegradable DOC from Arctic tributaries due to the lack of information available from the Great Lakes region (Bennington et al., 2012). Improving our understanding of $\mathrm{C}$ biodegradability in Great Lakes tributaries will enhance our understanding of near-shore microbial processing and our ability to create robust $\mathrm{C}$ models of these dynamic freshwater ecosystems.

Nitrogen and carbon cycles are tightly coupled in streams (Bernhardt and Likens, 2002; Johnson et al., 2012). As such, $\mathrm{N}$ availability or stoichiometric C:N ratios may limit microbial breakdown of DOC in some aquatic systems, presumably due to $\mathrm{N}$ limitation of microbial growth (Holmes et al., 2008; Wickland et al, 2012). Previous studies conducted in temperate streams have found that additions of labile DOC to streams resulted in increased $\mathrm{N}$ removal by stimulating microbial processing (Bernhardt and Likens, 2002; Sobczak et al., 2003; Johnson et al. 2012). Bernhardt and Likens (2002) also found that labile DOC additions resulted in shortened uptake lengths of $\mathrm{NH}_{4}$ and nitrate $\left(\mathrm{NO}_{3}\right)$, suggesting a concomitant increase in inorganic $\mathrm{N}$ demand with increasing DOC bioavailability. In another experiment, additions of $\mathrm{N}$ and $\mathrm{P}$ to a stream for 5-years resulted in an increase in microbial (fungal and bacterial) production, a decrease in leaf standing crop, and an increase in leaf decomposition rates, suggesting $\mathrm{N}$ and $\mathrm{P}$ alter in-stream processing of particulate organic C (Greenwood et al., 2007; Suberkropp et al., 2010). Therefore, $\mathrm{C}$ mineralization rates may be limited by the availability of $\mathrm{C}$ or $\mathrm{N}$, and these limitations may change in light of temporal changes in 
DOM inputs and quality. To our knowledge, no studies have examined whether DOC mineralization or bioavailablity is limited by either $\mathrm{C}$ or $\mathrm{N}$ availability in Great Lakes tributaries.

Despite the potential for high rates of DOC processing in small streams, we know little about these rates in Great Lakes tributary streams or the relative importance of elemental limitations on DOC mineralization throughout the year. The objective of this study was to determine whether DOC mineralization rates or \%BDOC exhibited elemental limitations in a forested Lake Superior tributary stream, and whether limitation varied within a year based on changes in watershed $\mathrm{C}$ and $\mathrm{N}$ inputs. We conducted nutrient amendment experiments using laboratory incubations of stream water to determine whether the rate of $\mathrm{DOC}$ mineralization or the \% $\mathrm{BDOC}$ was stimulated by additions of labile $\mathrm{C}$ and $\mathrm{N}$. Because elemental limitation may exhibit temporal variability, we repeated these experiments on four dates (April, January, July, October). Through these experiments we sought to better understand the role of in-stream DOC processing over an annual cycle, and the consequences for export to Lake Superior.

\section{Methods}

\section{Site description}

These experiments were conducted with stream water from Calumet watershed $\left(1.76 \mathrm{~km}^{2}\right)$, a small temperate tributary located on the south shore of Lake Superior in Michigan's Upper Peninsula, USA (lat $47^{\circ} 17^{\prime \prime}$ N, long $88^{\circ} 34^{\prime}$ W). This watershed has been continuously monitored since 1979 and research at this site has included study of terrestrial ecosystem processes, snowpack dynamics, and stream water chemistry 
(Stottlemyer and Toczdylowski, 2006). Stream water discharge is continuously monitored near the mouth of the watershed by a Parshall flume equipped with a Stevens pressure transducer (Stevens Water Monitoring Systems Inc., Portland, Oregon) and LiCor datalogger (Li-Cor, Lincoln, Nebraska) installed approximately $100 \mathrm{~m}$ upstream from Lake Superior (Stottlemyer and Toczdylowski, 2006). Dominant overstory vegetation consists primarily of sugar maple (Acer saccharum Marsh.) and white birch (Betula papyrifera Marsh.); bedrock consists primarily of Cambrian Freda sandstones, alkaline till and old beach deposits (Stottlemyer and Toczdylowski, 2006); and mean annual precipitation is $80 \pm 20 \mathrm{~cm}$ (Stottlemyer and Toczydlowski, 1996) with up to $50 \%$ occurring as snowfall (Stottlemyer, 1997).

\section{Sample collection and analysis}

Stream water was collected once per season with sampling dates selected to target characteristic environmental conditions: July, during leaf-out; October, during leaf senescence; January, during snow cover; and April, during snow-melt. Stream water samples were pooled from multiple locations within a $200 \mathrm{~m}$ reach located immediately upstream of the flume, filtered through $0.45 \mu \mathrm{m}$ nylon membrane filters within $4 \mathrm{~h}$ of collection, and kept at a temperature of $4^{\circ} \mathrm{C}$ until the experiment was set up, which occurred within 24 hours. Three of the four experiments were conducted during a oneyear period in 2012-2013 (July 2012, October 2012, and April 2013). Due to analytical problems during a January 2012-2013 experiment, the January experiment was repeated in 2013-2014, and only data from this later period is reported. 
Initial stream water characteristics were analyzed for each experiment. Stream water temperature, conductivity, $\mathrm{pH}$, turbidity, and dissolved oxygen were measured using a YSI 6920 multiparameter sonde (YSI Incorporated, Yellow Springs, Ohio); during October 2012, these measurements were taken 13 days following sample collection due to equipment issues. Initial stream $\mathrm{NH}_{4}$ concentrations were determined using the fluorometric method (Holmes et al. 1999, Taylor et al. 2007) and analyzed with an Aquafluor handheld fluorometer (Turner Designs, Sunnyvale, California). Initial DOC and total dissolved nitrogen (TDN) concentrations were determined on acidified samples and analyzed using a TOC-5000A analyzer (Shimadzu Scientific Instruments, Columbia, Maryland). DOC quality was characterized using specific ultra violet absorbance measured with a GENESYS ${ }^{\mathrm{TM}}$ 10s UV-Vis spectrophotometer (Thermo Scientific, Waltham, Massachusetts). SUVA 254 , which is defined as the specific absorbance at $\lambda=254 \mathrm{~nm}$ divided by the DOC concentration, was calculated as an indicator of DOC aromaticity (Weishaar et al., 2003).

\section{Experimental Design}

To determine whether DOC mineralization rates were limited by availability of labile nitrogen or labile carbon, we utilized a full factorial experimental design, amending with $\mathrm{N}$ as $\mathrm{NH}_{4} \mathrm{Cl}$, labile DOC as glucose, a combination of $\mathrm{N}\left(\mathrm{NH}_{4} \mathrm{Cl}\right)$ and labile DOC (glucose), or MilliQ water as a no-nutrient control. Each treatment was applied to 12 replicate bottles, resulting in 48 bottles total in each experiment. Amendments increased ambient DOC by $1 \mathrm{mg} / \mathrm{L}$ and ambient $\mathrm{NH}_{4}$ by $5 \mu \mathrm{g} \mathrm{N} / \mathrm{L}$, resulting in 0.1 to $0.2 \mathrm{X}$ increases in background DOC concentrations and 1.8 to $4.9 \mathrm{X}$ increases in background 
$\mathrm{NH}_{4}-\mathrm{N}$ concentrations. Although the degree of $\mathrm{N}$ enrichment appears to be much greater than that we used for C, it should be noted that most of the background DOC present in the stream on any given date is resistant to degradation. Therefore, our addition of labile $\mathrm{C}$ relative to the initial amount of labile $\mathrm{C}$ present in the stream may actually be much greater than that reflected by total DOC concentrations.

To initialize each experiment, $120 \mathrm{~mL}$ amber glass serum bottles (48 total) were filled with $50 \mathrm{~mL}$ of filtered ( $0.45 \mu \mathrm{m}$ Nylon membrane) stream water and inoculated with $1 \mathrm{~mL}$ of a mixture of unfiltered stream water and stream sediment to introduce a microbial assemblage of organisms from the water column and the benthos. For the inoculum, three sediment cores $(2 \mathrm{~cm}$ diameter) were collected to a depth of $1 \mathrm{~cm}$ on each sampling date, covered with parafilm to reduce evaporation, and kept cold until the experiment was initiated (within 24 hours). To make the inoculum, one g of sediment (maintaining field moisture conditions) from each core was measured and added to 500 $\mathrm{mL}$ of unfiltered stream water. We used different inoccula for the experiments to mimic in situ stream conditions on a particular sampling date. However, because each inoculum was different, any changes in DOC mineralization rates observed among experiments may be due to either differences in the microbial community or DOC composition. Following inoculation, the bottles were sealed with butyl rubber septa, placed on a shaker in the dark, and incubated at room temperature $\left(21^{\circ} \mathrm{C} \pm 3^{\circ}\right)$.

On day $0,1,3,5,7,14$ and $28, \mathrm{CO}_{2}$ was measured in all vials by withdrawing 1 $\mathrm{mL}$ aliquots of the equilibrated headspace and analyzing using a SRI $8610 \mathrm{C}$ gas chromatograph (SRI Instruments, Torrance, California; TCD detector, He carrier gas, Hayesep D packed column, column temperature $62^{\circ} \mathrm{C}$ ). The volume of headspace 
removed was replaced with an equal amount of $\mathrm{N}_{2}$ or air. When air was added, the amount of $\mathrm{CO}_{2}$ generated over the course of the experiment was corrected to account for $\mathrm{CO}_{2}$ introduced. On one date (July experiment day 7) analytical issues prevented sample analysis on the day that headspace aliquots were collected, and these samples have been excluded from further analysis. Calibration curves were created with 1000 ppm $\mathrm{CO}_{2}$ standard. Following headspace analysis on days 0 and 28, 3 replicate bottles per treatment were acidified with $2 \mathrm{~mL}$ of $43.5 \% \mathrm{H}_{3} \mathrm{PO}_{4}$ to convert all dissolved inorganic carbon (DIC) to $\mathrm{CO}_{2}$ and the headspace was analyzed again for $\mathrm{CO}_{2}$ as described above. On days 0,14 and 28, water from an additional 3 replicate bottles per treatment were analyzed for DOC, TDN and $\mathrm{SUVA}_{254}$ as described above.

Percent BDOC was calculated using the following equation from Wickland et al. (2012):

$$
\% \text { BDOC }=\frac{\text { DIC }_{\text {final }}-\mathrm{DIC}_{\text {initial }}}{\text { DOC }_{\text {initial }}}
$$

where DIC and DOC are expressed in $\mathrm{mg}$ C. Using DIC produced over the incubation period to determine $\mathrm{CO}_{2}$ production accounts for any changes in DIC form due to changes in $\mathrm{pH}$ during the incubation and assumes the change in DIC is completely due to respiration of DOC (Wickland et al., 2007). For these calculations, DOC initial was adjusted for the $\mathrm{C}$ added to treatment vials such that $1 \mathrm{mg} \mathrm{C} / \mathrm{L}$ was added to the initial stream water DOC concentration measured prior to experiment intialization. 


\section{Statistical Analyses}

To assess whether $\mathrm{C}$ or $\mathrm{N}$ treatments affected rates of DOC mineralization we analyzed the dataset in two ways: 1) using the measured $\mathrm{CO}_{2}$ concentration on each sampling date (days $0,1,3,5,7,14,21,28)$; and 2) using the percent BDOC. To determine whether $\mathrm{CO}_{2}$ production differed among day, $\mathrm{C}$ amendment, or $\mathrm{N}$ amendment on each date we used a three-way repeated measures analysis of variance (ANOVA) with $\mathrm{C}, \mathrm{N}$, and day as factors. To determine if \%BDOC differed among $\mathrm{C}$ amendment or $\mathrm{N}$ amendment on each date we used a two-way ANOVA with $\mathrm{C}$ and $\mathrm{N}$ as factors. To assess whether DOC mineralization varied temporally we used a one-way analysis of variance of \%BDOC in control vials with date as the factor. Data were log-transformed when necessary to meet assumptions of normality. For all statistical analyses, alpha was set $a$ priori at 0.05 . All statistical analyses were conducted with SAS version 9.2 (SAS Institute, Cary, North Carolina).

\section{Results}

Nutrient amendments and microbial $\mathrm{CO}_{2}$ production over time

Our results support the hypothesis that $\mathrm{N}$ or $\mathrm{C}$ additions affect DOC mineralization rates in a small northern hardwood forest stream. Analysis of microbial $\mathrm{CO}_{2}$ production over the incubation period revealed significant differences among time and treatments within each of the four experiments (Fig. 1). Labile $\mathrm{C}$ additions alone or in combination with $\mathrm{N}$ increased $\mathrm{CO}_{2}$ production in all four experiments. $\mathrm{NH}_{4}$ additions alone or in combination with $\mathrm{C}$ increased $\mathrm{CO}_{2}$ production in July, October and April experiments, but not in the January experiment (Fig. 1). 
During the July experiment (Fig. 1a), there was a significant interaction of C $\mathrm{x}$ day $\left(F_{(6,120)}=5.7, p<0.001\right), \mathrm{N} \times$ day $\left(F_{(6,120)}=3.1, p=0.007\right)$, and $\mathrm{C} \times \mathrm{N}\left(F_{(1,20)}=13.6\right.$, $p=0.002)$ on $\mathrm{CO}_{2}$ concentration. The interactive effect of $\mathrm{C}$ and $\mathrm{N}$ in the July experiment resulted in the greatest production of $\mathrm{CO}_{2}$ in the $\mathrm{CN}$ treatment relative to other treatments. The July mean $\mathrm{CO}_{2}$ production on day 28 was $1.10 \mathrm{X}$ greater in the $\mathrm{CN}$ treatment than the control treatment, but $\mathrm{CO}_{2}$ production in $\mathrm{C}$ and $\mathrm{N}$ alone treatments were $0.95 \mathrm{X}$ and $0.98 \mathrm{X}$ below that of the control, respectively (Fig.1).

Microbial $\mathrm{CO}_{2}$ production also varied significantly in the October experiment (Fig. 1b) with a significant interaction of $\mathrm{C} x$ day $\left(F_{(7,135)}=5.8, p<0.001\right)$ and $\mathrm{N} \mathrm{x}$ day $\left(F_{(7,135)}=3.2, p=0.004\right)$. Mean $\mathrm{CO}_{2}$ production on day 28 in the $\mathrm{C}$ treatment was $1.27 \mathrm{X}$ the $\mathrm{CO}_{2}$ production in the control, the $\mathrm{N}$ treatment was $1.17 \mathrm{X}$ the control, and the $\mathrm{CN}$ treatment was $1.47 \mathrm{X}$ the control.

In the January experiment (Fig. 1c) there was only a significant interaction of $\mathrm{C} \mathrm{x}$ day $\left(F_{(7,140)}=60.4, p<0.001\right)$. Mean $\mathrm{CO}_{2}$ production on day 28 in the $\mathrm{C}$ treatment was 1.52X greater than the control and the $\mathrm{CN}$ treatment was $1.47 \mathrm{X}$ greater than the control. In the April experiment (Fig. 1d) there was a significant interaction of $\mathrm{C} \mathrm{x}$ day $\left(F_{(7,140)}=25.8, p<0.001\right)$ and $\mathrm{C} \mathrm{x} \mathrm{N}\left(F_{(1,20)}=4.7, p=0.04\right)$. Mean $\mathrm{CO}_{2}$ production on day 28 in the $\mathrm{C}$ treatment was $1.29 \mathrm{X}$ greater than the $\mathrm{CO}_{2}$ production in the control, the $\mathrm{N}$ treatment was $1.12 \mathrm{X}$ greater than the control, and the $\mathrm{CN}$ treatment was $1.30 \mathrm{X}$ greater than the control.

Analysis of \%BDOC also showed that additions of $\mathrm{N}$ in the October experiment increased DOC mineralization rates, agreeing with the observations of $\mathrm{CO}_{2}$ production through time (Fig 2). The \%BDOC differed significantly among treatments in October 
(overall ANOVA $\left.F_{(3,8)}=7.1, p=0.01\right)$ with a significant effect of $\mathrm{N}\left(F_{(1,8)}=14.5, p=\right.$ 0.005 ). October mean $\% \mathrm{BDOC}$ was $1.5 \mathrm{x}$ greater in the $\mathrm{N}$ treatment and $2.4 \mathrm{x}$ greater in the $\mathrm{CN}$ treatment compared to the control (Fig. 2). The \%BDOC did not differ among treatments in July $\left(F_{(3,8)}=1.3, p=0.33\right)$, January $\left(F_{(3,8)}=0.8, p=0.55\right)$, or April $\left(F_{(3,8)}=\right.$ $2.7, p=0.12)$.

To determine whether consumption of $\mathrm{C}$ in this experiment exceeded the amount of labile $\mathrm{C}$ added to incubation vials, we first assumed that labile $\mathrm{C}$ would have been completely consumed before any of the background $\mathrm{C}$ present in the stream water at the initiation of the experiment. We then calculated the total $\mathrm{C}$ consumed based on $\mathrm{CO}_{2}$ produced by day 28 of each experiment in each C-amended treatment, and compared the amount of $\mathrm{C}$ consumed to the $\mathrm{C}$ added. Using this approach, we estimated that the maximum percent of the labile $\mathrm{C}$ added that could have been consumed ranged from 52.2 to $81.1 \%$ in $\mathrm{C}$ amendments and 42.9 to $81.0 \%$ in $\mathrm{CN}$ amendments (Table 1). Therefore, while our addition rate of labile $\mathrm{C}$ was conservative, the labile $\mathrm{C}$ added was not completely consumed during any of the four experiments.

\section{Temporal variability of biodegradable DOC \& stream conditions}

Our results revealed that $\% \mathrm{BDOC}$ varied among sampling dates with significantly greater $\% \mathrm{BDOC}$ in control treatments in July (40.6\%) than in October $(10.2 \%)$ or January (9.6\%), but July \%BDOC did not differ from April $\left(18.4 \% ; F_{(3,8)}=5.7, p=\right.$ 0.02). The lowest DOC concentrations were observed in October and January, which were at least $2 \mathrm{mg} \mathrm{C} / \mathrm{L}$ below concentrations observed in July and April (Table 2). Three of the four experiments occurred during base flow conditions; only the April experiment 
occurred under elevated discharge (Table 2). The greatest initial SUVA254 values, an indicator of $\mathrm{C}$ aromaticity, were observed in October and the lowest $\mathrm{SUVA}_{254}$ values were observed in January (Table 2).

\section{Discussion and Conclusions}

The results of our experiments show that $\mathrm{NH}_{4}$ and labile $\mathrm{C}$ additions can stimulate DOC mineralization rates throughout the year in a small Lake Superior tributary. Interestingly, we found that $\mathrm{NH}_{4}$ and labile $\mathrm{C}$ additions can stimulate $\mathrm{C}$ mineralization rates in October, at a time when leaf litter inputs already supply a substantial C subsidy to forested streams surrounding Lake Superior's shores. To our knowledge, this is the first study to identify elemental limitation of DOC mineralization rates and quantify \%BDOC in any tributaries of Lake Superior. Our results suggest that small headwater streams supply high quality biodegradable C to Lake Superior year-round.

\section{$\mathrm{NH}_{4}$ and labile $\mathrm{C}$ amendments stimulate DOC mineralization rates}

The results of our nutrient amendment experiments suggest that $\mathrm{NH}_{4}$ availability can limit $\mathrm{C}$ mineralization rates during much of the year in forested tributaries of the Great Lakes, and particularly during leaf-fall. Furthermore, additions of $\mathrm{NH}_{4}$ and labile C stimulated DOC mineralization in both April and July when stream \%BDOC is greatest, suggesting the relatively high quality $\mathrm{C}$ found at these times could be further mineralized with increased supply of $\mathrm{NH}_{4}$ or labile $\mathrm{C}$. The only experiment where $\mathrm{NH}_{4}$ amendments did not increase $\mathrm{C}$ mineralization rates was in January, when only labile $\mathrm{C}$ additions increased $\mathrm{CO}_{2}$ production. The temporal variability in $\mathrm{NH}_{4}$ limitation in our 
experiments could be explained by the availability of $\mathrm{C}$ and $\mathrm{N}$ in stream water at the start of each experiment. The ratio of DOC:TDN was lowest at the start of the January experiment (17.06), which was the only season when $\mathrm{NH}_{4}$ was not limiting or colimiting, and greatest for the October experiment (24.21) relative to April (20.48) and July (18.74). Furthermore, background $\mathrm{NH}_{4}$ concentrations were elevated in the January experiment relative to the others, which appears to have alleviated $\mathrm{NH}_{4}$ limitation during this experiment (Table 2). In Alaskan rivers, Wickland et al. (2012) found the lowest DOC:DIN molar ratios occurred in winter relative to spring and summer, but they also found the greatest $\% \mathrm{BDOC}$ in winter. In contrast, the low DOC:TDN ratio in our January experiment did not correspond with the greatest \%BDOC. Low stream water temperatures, the presence of stream ice cover, or variability in the microbial community during January could contribute to the low \%BDOC we observed.

Our results revealed an increase in DOC mineralization when labile $\mathrm{C}$ was added, and further revealed that there can be $\mathrm{C}$ limitation of DOC mineralization in October, when leaf litter subsidies to the stream are highest. Upon leaf litter entering the stream, rapid leaching of DOM occurs within a matter of days (McDowell and Fisher, 1976; Meyer et al., 1998). As leaf litter is broken down, DOC is also generated through chemical leaching, microbial breakdown, and invertebrate feeding (Meyer and O'Hop, 1983; Meyer et al., 1998). Water collection for our October experiment (10/7/2012) likely occurred during a period of rapid DOC leaching from newly fallen leaves, as the majority of leaves had fallen in the watershed immediately preceding that sample date (58\% of the total input of deciduous leaves occurred between 9/29/2012 and 10/5/2012, Coble unpublished data). Furthermore, the greater $\mathrm{SUVA}_{254}$ values observed in October 
suggest greater aromaticity of stream DOC during October than on other dates, which could explain the observed response to labile $\mathrm{C}$ additions during this experiment. However, the lowest SUVA254 values, indicating lower aromaticity of DOC, were observed in the January experiment, which also responded positively to labile C additions. Despite the presence of leaf litter in the stream and potential DOC generation from leaf litter breakdown, our results reveal that DOC mineralization in October can still be limited by the availability of labile $\mathrm{C}$.

\section{Comparison of \%BDOC estimates to other studies}

Variability in \%BDOC can be as great within a single lake (Weiss and Simon, 1999) or stream (Volk et al. 1997) as among aquatic ecosystems (e.g. Søndergaard and Middelboe, 1995). In our study, $\%$ BDOC varied from $10 \%$ to $41 \%$ within a single stream. In comparison, Volk et al. (1997) measured \%BDOC on 25 different dates between January and April of a single year from a small stream draining an agricultural watershed in southeastern Pennsylvania and found \%BDOC ranged from 16.5 to $34.4 \%$. Other studies examining the $\%$ BDOC among streams of varying sizes found $\%$ BDOC did not vary among streams in Alaska (drainage areas: 3,315 to $831,386 \mathrm{~km}^{2}$; Wickland et al., 2012) or streams in the eastern United States (drainage areas: $0.46 \mathrm{~km}^{2}$ to $36,260 \mathrm{~km}^{2}$; Wiegner et al. 2006). Despite the lack of differences among stream sizes, a high degree of temporal variability (4 to 53\%) was observed in \%BDOC measured from Alaskan streams between January and September (Wickland et al., 2012). Caution must be used when comparing \%BDOC values among studies because differences in methodologies (microbial inoculum, incubation temperatures, and incubation time) may affect these 
values. Notwithstanding, our estimates of \%BDOC are in agreement with previous studies and suggest that temporal variability in biodegradable carbon export likely occurs in northern temperate streams, like those draining into Lake Superior.

\section{Potential for \%BDOC export to Lake Superior}

Although previous studies have discussed potential seasonal variations in DOC lability in Lake Superior streams, they have largely relied on proxy estimates of \%BDOC from Arctic tributaries. For example, in their model of Lake Superior's carbon budget, Bennington et al. (2012) assumed, based on Arctic measurements from Holmes et al. (2008), that $15 \%$ of DOC was biodegradable for the 9 largest tributaries of Lake Superior, and they considered this to be a relatively high estimate of lability. By comparison, our study revealed that \%BDOC in a small Lake Superior tributary averaged 19.7\% among the four experiment dates, and the proximity of our study site to Lake Superior ( $\sim 100 \mathrm{~m}$ from the mouth) suggests this BDOC is most likely exported directly to the near-shore environment. Applying our estimate of 19.7\% BDOC and assuming that similar \%BDOC occurs across all Lake Superior tributaries, we estimate that of the 0.4 to $0.9 \mathrm{Tg}$ C/yr exported from Lake Superior tributaries (Urban et al., 2005), 0.08 to $0.18 \mathrm{Tg}$ $\mathrm{C} / \mathrm{yr}$ is in biodegradable form.

The fate of the BDOC exported from tributaries to nearshore Lake Superior may depend on the timing of export. In our study, \%BDOC varied from 10 to $41 \%$ (but note that January \%BDOC could be negligible due to the high standard error observed; Table 2). Therefore, at times, stream $\% \mathrm{BDOC}$ will be substantially greater than the $15 \%$ estimated by Bennington et al. (2012) and the 19.7\% we used in our annual estimate 
above. Relatively high quality DOC exported during July provides DOC at a time when downstream water temperatures are elevated. Bidanda and Cotner (2002) found that bacterial respiration in Lake Michigan was much greater in summer than in winter, supporting the concept that elevated temperatures increase maintenance costs and reduce bacterial growth efficiency. Thus, high quality riverine $\mathrm{C}$ exported to the near-shore region of Lake Superior may support greater rates of bacterial respiration in the summer when temperatures are elevated.

Our results also have implications for understanding how C loads to Lake Superior may scale across tributaries and how they may change through time. The $\mathrm{C}$ budget for Lake Superior remains imbalanced, with respiration losses that greatly exceed primary production (Urban et al., 2005; Bennington et al., 2012). Our results suggests that the abundance of small streams surrounding Lake Superior's shorelines may provide important inputs of biodegradable C to Lake Superior that, when considered cumulatively and annually, may help explain this imbalance. Spring snowmelt represents a significant proportion of the hydrologic budget of Lake Superior tributaries and also accounts for a substantial amount of annual DOC loads (Stottlemyer et al., 1998; Stottlemyer and Toczydlowski, 2006). Our results suggest that spring snowmelt may transport large quantities of relatively high quality ( $18 \% \mathrm{BDOC}) \mathrm{DOC}$ from small headwater streams to Lake Superior. Furthermore, this export of high quality DOC occurs within the same season that has exhibited increasing DOC concentrations over a 15 -year period (Stottlemyer and Toczydlowski, 2006). As such, future export of \%BDOC during snowmelt may change if export of DOC continues to increase. Finally, although anthropogenic $\mathrm{N}$ enrichment is not a major concern for Lake Superior tributaries, our 
results suggest that any increase in $\mathrm{N}$ availability in Great Lakes tributaries may enhance C mineralization rates, affect in-stream DOC processing, and ultimately alter export of biodegradable $\mathrm{C}$ to the Great Lakes.

\section{Acknowledgements}

This research was funded by a Research Seed Grant from Michigan

Technological University's Research Excellence Fund and by the USDA-funded

McIntire-Stennis program. Ashley Coble was supported by the NSF GK-12 Global

Watershed Program at Michigan Technological University program (award DGE-

0841073). We thank Jennifer Eikenberry, Kellie Heiden, Jeffrey Kiiskila, Jade Ortiz, and Kyle Price for laboratory assistance. We thank Robert Stottlemyer and David Toczydlowski for establishing this long-term study site on Lake Superior's south shore. 


\section{References}

Aiken, G.R., Hsu-Kim, H., Ryan, J.N., 2011. Influence of dissolved organic matter on the environmental fate of metals, nanoparticles, and colloids. Environ. Sci. Technol. 45, 3196-3201.

Bennington, V., McKinley, G.A., Urban, N.R., McDonald, C.P., 2012. Can spatial heterogeneity explain the perceived imbalance in Lake Superior's carbon budget? A model study. J. Geophys. Res. 117, G03020.

Bernhardt, E.S., Likens, G.E., 2002. Dissolved organic carbon enrichment alters nitrogen dynamics in a forest stream. Ecology 83, 1689-1700.

Biddanda, B.A., Cotner, J.B., 2002. Love handles in aquatic ecosystems: the role of dissolved organic carbon drawdown, resuspended sediments, and terrigenous inputs in the carbon balance of Lake Michigan. Ecosystems 5, 431-445.

Buffam, I., Galloway, J.N., Blum, L.K., McGlathery, K.J., 2001. A stormflow/baseflow comparison of dissolved organic matter concentrations and bioavailability in an Appalachian stream. Biogeochemistry 53, 269-306.

Butman, D., Raymond, P.A., 2011. Significant efflux of carbon dioxide from streams and rivers in the United States. Nat. Geosci. 4, 829-842.

Cole, J. J., Prairie, Y.T., Caraco, N.R., McDowell, W.H., Tranvik, L.J., Striegl, R.G., Duarte, C.M., Kortelainen, P., Downing, J.A., Middelburg, J.J., Melack, J., 2007. Plumbing the Global Carbon cycle: integrating inland waters in to the terrestrial carbon budget. Ecosystems 10, 171-184. 
Findlay, S.E.G., 2003. Bacterial response to variation in dissolved organic matter, in: S. E. G. Findlay and R. L. Sinsabaugh (Eds.), Aquatic ecosystems: interactivity of dissolved organic matter. Academic Press, San Diego, California, pp. 363-377.

Frost, P.C., Larson, J.H., Johnston, C.A., Young, K.C., Maurice, P.A., Lamberti, G.A., Bridgham, S.D., 2006. Landscape predictors of stream dissolved organic matter concentration and physicochemistry in a Lake Superior river watershed. Aquat. Sci. 68, 40-51.

Greenwood, J.L., Rosemond, A.D., Wallace, J.B., Cross, W.F., Weyers, H.S., 2007. Nutrients stimulate leaf breakdown rates and detritivore biomass: bottom-up effects via heterotrophic pathways. Oecologia 151, 1088-1093.

Holmes, R.M., Aminot, A., Kerouel, R., Hooker, B.A., Peterson, B.J., 1999. A simple and precise method for measuring ammonium in marine and freshwater ecosystems. Can. J. Fish. Aquat. Sci. 56, 1801-1808.

Holmes, R.M., McClelland, J.W., Raymond, P.A., Frazer, B.B., Peterson, B.J., Stieglitz, M., 2008. Lability of DOC transported by Alaskan rivers to the Arctic Ocean. Geophys. Res. Lett. 35, L03402.

Johnson, L.T., Royer, T.V., Edgerton, J.M., Leff, L.G., 2012. Manipulation of the dissolved organic carbon pool in an agricultural stream: responses in microbial community structure, denitrification, and assimilatory nitrogen uptake.

Ecosystems 15, 1027-1038.

Jonsson, A., Karlsson, J., Jansson, M., 2003. Sources of carbon dioxide supersaturation in clearwater and humic lakes in northern Sweden. Ecosystems 6, 224-235. 
Karlsson, J., Jansson, M., Jonsson, A. 2007. Respiration of allochthonous organic carbon in unproductive forest lakes determined by the Keeling plot method. Limnol. Oceanogr. 52, 603-608.

Macdonald, M.J., Minor, E.C., 2013. Photochemical degradation of dissolved organic matter from streams in the western Lake Superior watershed. Aquat. Sci. 75, 509522.

McCallister, S.L., del Giorgio, P.A., 2008. Direct measurement of the ${ }^{13} \mathrm{C}$ signature of carbon respired by bacteria in lakes: linkages to potential carbon sources, ecosystem baseline metabolism, and $\mathrm{CO}_{2}$ fluxes. Limnol. Oceanogr. 53, 1204 1216.

McDowell, W.H., Fisher, S.G., 1976. Autumnal processing of dissolved organic matter in a small woodland stream ecosystem. Ecology 57, 561-569.

Meyer, J.L., O'Hop, J., 1983. Leaf-shredding insects as a source of dissolved organic carbon in headwater streams. Am. Midl. Nat. 109, 175-183.

Meyer, J.L., Wallace, B.J., Eggert, S.L., 1998. Leaf litter as a source of dissolved organic carbon in streams. Ecosystems 1, 240-249.

Mulholland, P. J., Hill, W.R., 1997. Seasonal patterns in streamwater nutrient and dissolved organic carbon concentrations: separating catchment flow path and instream effects. Water Resour. Res. 33, 1297-1306.

Sobczak,W. V., Findlay, S., Dye, S., 2003. Relationships between DOC bioavailability and nitrate removal in an upland stream: an experimental approach. Biogeochemistry 62, 309-327. 
Sholkovitz, E.R., 1976. Flocculation of dissolved organic and inorganic matter during mixing of river water and seawater. Geochim. Cosmochim. Ac. 40, 831-845.

Søndergaard, M., Middelboe, M., 1995. A cross-system analysis of labile dissolved organic carbon. Mar. Ecol. Prog. Ser. 118, 283-294.

Stottlemyer, R., Toczydlowski, D., Herrmann, R., 1998. Biogeochemistry of a mature boreal ecosystem: Isle Royale National Park, Michigan. Scientific monograph NPR/NRUSGS/NRSM-98/01. United States Department of the Interior, National Park Service, Fort Collins, Colorado.

Stottlemyer, R., 1997. Streamwater chemistry in watersheds receiving different atmospheric inputs of $\mathrm{H}^{+}, \mathrm{NH}_{4}{ }^{+}, \mathrm{NO}_{3}{ }^{-}$, and $\mathrm{SO}_{4}{ }^{2-}$. J.Am. Water Resour. As. 33, $767-780$.

Stottlemyer, R., Toczydlowski, D., 1996. Modification of snowmelt chemistry by forest floor and mineral soil, Northern Michigan. J. Environ. Qual. 25, 828-836.

Stottlemyer, R., Toczydlowski, D., 2006. Effect of reduced winter precipitation and increased temperature on watershed solute flux, 1988-2002, Northern Michigan. Biogeochemistry 77, 409-440.

Suberkropp, K., Gulis, V., Rosemond, A.D., Benstead, J.P., 2010. Ecosystem and physiological scales of microbial responses to nutrients in a detritus-based stream: results of a 5-year continuous experiment. Limnol. Oceanogr. 55, 149-160.

Taylor, B.W., Keep, C.F., Hall, R.O., Koch, B.J., Tronstad, L.M., Flecker, A.S., Ulseth, A.J., 2007. Improving the fluorometric ammonium method: matrix effects, background fluorescence, and standard additions. J. N. Am. Benthol. Soc. 26, $167-177$. 
Urban, N.R., Auer, M.T., Green, S.A., Lu, X., Apui, D.S., Powell, K.D., Bub, L., 2005. Carbon cycling in Lake Superior. J.Geophys. Res. 110, C06S90.

Volk, C.J., Volk, C.B., Kaplan, L.A., 1997. Chemical composition of biodegradable dissolved organic matter in streamwater. Limnol. Oceanogr. 42, 39-44.

Wallin, M.B., Grabs, T., Buffam, I., Laudon, H., Ågren, A., Öquist, M.G., Bishop, K., 2013. Evasion of $\mathrm{CO}_{2}$ from streams - The dominant component of the carbon export through the aquatic conduit in a boreal landscape. Glob. Change Biol. 19, $785-797$.

Weishaar, J.L., Aiken, G.R, Bergamaschi, B.A., Fram, M.S., Fujii, R., 2003. Evaluation of specific ultraviolet absorbance as an indicator of the chemical composition and reactivity of dissolved organic carbon. Environ. Sci. Technol. 37, 4702-4708.

Weiss, M., Simon, M., 1999. Consumption of labile dissolved organic matter by limnetic bacterioplankton: the relative significance of amino acids and carbohydrates. Aquat. Microb. Ecol. 17, 1-12.

Wickland, K.P., Neff, J.C., Aiken, G.R., 2007. Dissolved organic carbon in Alaskan boreal forest: sources, chemical characteristics and biodegradability. Ecosystems $10,1323-1340$.

Wickland, K.P., Aiken, G.R., Butler, K., Dornblaser, M.M., Spencer, R.G.M., Striegl, R.G., 2012. Biodegradability of dissolved organic carbon in the Yukon River and its tributaries: seasonality and importance of inorganic nitrogen. Glob. Biogeochem. Cycles 26, GBOE03. 
Wiegner, T.N., Seitzinger, S.P., Glibert, P.M., Bronk, D.A., 2006. Bioavailability of dissolved organic nitrogen and carbon from nine rivers in the eastern United States. Aquat. Microb. Ecol. 43, 277-287.

Wilson, H.F., Saiers, J.E., Raymond, P.A., Sobczak, W.V., 2013. Hydrologic drivers and seasonality of dissolved organic carbon concentration, nitrogen content, bioavailability, and export in a forested New England stream. Ecosystems 16, $604-616$.

Yoshioka, T., Ueda, S., Khodzher, T., Bashenkhaeva, N., Korovyakova, I., Sorokovikova, L., Gorbunova, L., 2002. Distribution of dissolved organic carbon in Lake Baikal and its watershed. Limnology 3, 159-168 
Table 1. Maximum amount of added labile $\mathrm{C}$ consumed in each experiment, estimated by comparing to total $\mathrm{CO}_{2}$ production over the 28 day incubation period and assuming that the $1 \mathrm{mg} / \mathrm{L}$ of labile $\mathrm{C}$ added would be consumed before background $\mathrm{C}$ present.

\begin{tabular}{rrr}
\hline Date & \multicolumn{2}{c}{$\begin{array}{c}\text { Maximum consumption of } \\
\text { added labile C (\%) }\end{array}$} \\
\cline { 2 - 3 } & $\mathrm{C}$ & \multicolumn{2}{c}{$\mathrm{CN}$} \\
& amendment & amendment \\
\hline 16 Jul 2012 & 52.2 & 42.9 \\
7 Oct 2012 & 72.6 & 56.4 \\
5 Jan 2014 & 64.3 & 68.1 \\
26 Apr 2013 & 81.1 & 81.0 \\
\hline
\end{tabular}




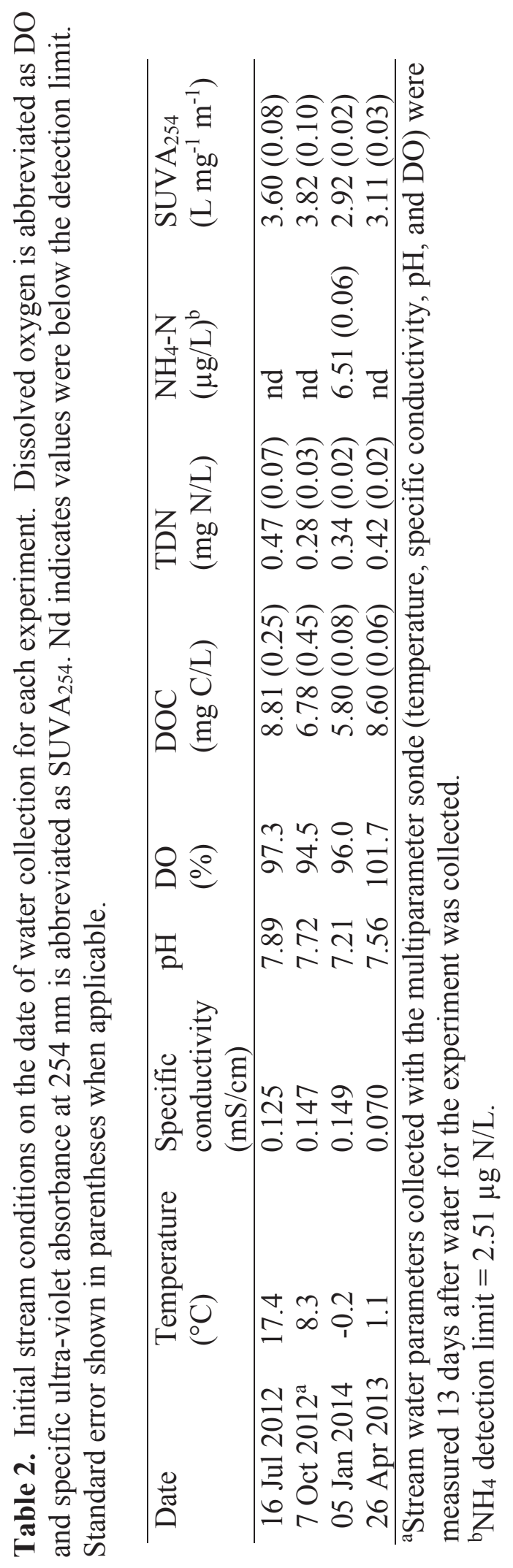




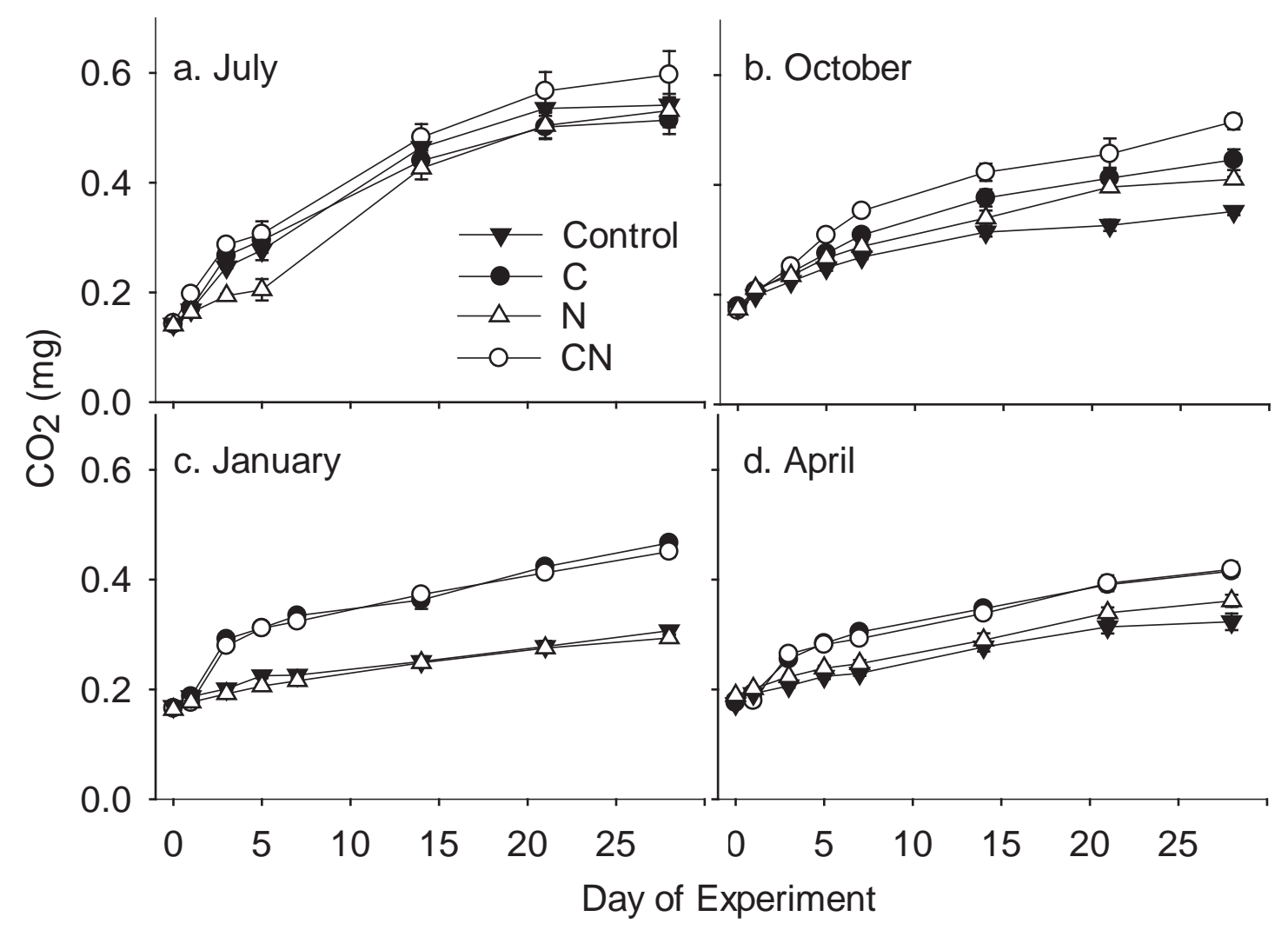

Figure 1. Mean $\mathrm{CO}_{2}$ production versus day during the 28 day period for the four experiments conducted in (a) July (b) October (c) January and (d) April. Error bars represent \pm 1 standard error ( $n=6$ for each point). Note that during the July experiment, day 7 samples and standards were excluded due to methodological issues as explained in the methods. 


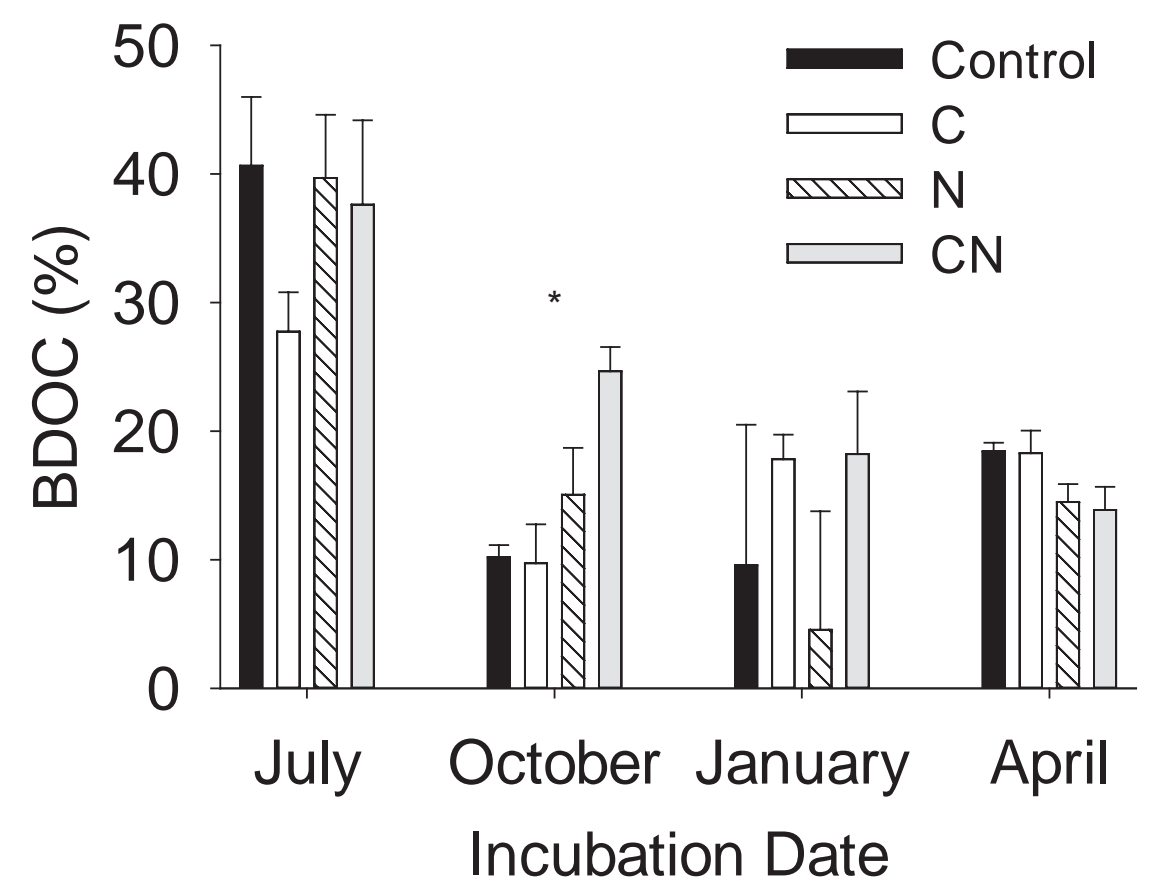

Figure 2. Percent biodegradable DOC (\%BDOC) measured in each treatment for the four experiments. Asterisk denotes significant differences among treatments within each season as determined with a two-way analysis of variance. Error bars represent \pm 1 standard error ( $n=3$ for each point). 
Chapter 3: Seasonal patterns of dissolved organic matter biodegradability are similar across three northern temperate rivers ${ }^{a}$

Authors

Ashley A. Coble ${ }^{1 *}$, Amy M. Marcarelli ${ }^{1}$, Evan S. Kane ${ }^{2,3}$, Robert Stottlemyer ${ }^{1}$, David Toczydlowski ${ }^{1}$

* corresponding author, Email: aacoble@mtu.edu, Phone: 620200 7696, Fax: 906487

3167

${ }^{1}$ Department of Biological Sciences, Michigan Technological University, 1400 Townsend

Drive, Houghton, Michigan 49931

${ }^{2}$ School of Forest Resources and Environmental Science, Michigan Technological

University, Houghton, Michigan 49931

${ }^{3}$ U.S. Forest Service, Northern Research Station, 410 MacInnes; Houghton, Michigan 49931

${ }^{a}$ This chapter was formatted to be submitted to the Journal of Geophysical Research Biogeosciences 


\section{Key Points}

DOM biodegradability varies synchronously among watersheds varying in size

DOM composition was only distinct among different watersheds during stormflow

$14 \%$ of average annual DOC export from these watersheds was biodegradable 


\begin{abstract}
Dissolved organic matter (DOM) composition may be an important determinant of its fate, but little is known about temporal variability in DOM composition and the biodegradability of dissolved organic carbon (BDOC) in northern temperate watersheds, which export $23 \%$ of total organic carbon globally. We measured BDOC via incubation assays and DOM composition using optical indices on eleven dates in 3 Lake Superior tributaries. BDOC was seasonally synchronous across these watersheds that vary in size by orders of magnitude (1.7 to $3400 \mathrm{~km}^{2}$ ), even during an August storm event when DOM composition greatly differed among sites. BDOC also varied within seasons; for example, BDOC on 2 different dates in winter when ice covered the rivers were among the highest and lowest BDOC observed. DOM composition varied the most among tributaries during a summer storm event, but was remarkably similar during fall, spring and winter. Multivariate models identified humic-like and tryptophan-like fluorophores as predictors of BDOC, but DOM composition only described $21 \%$ of the overall variation in BDOC. Collectively, we estimate that these three rivers export $18.12 \mathrm{Gg} \mathrm{C}$

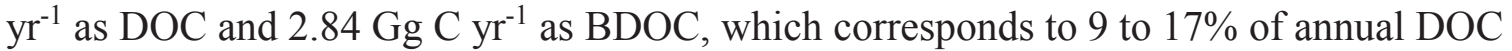
exported in biodegradable form. Modeling of historical (26 years) DOC and BDOC loads do not suggest that annual exports have changed to date, although spring loads of DOC and BDOC have increased. Future hydrologic and climatic changes may alter export of BDOC if they change the timing of major seasonal and hydrologic events like storms.
\end{abstract}




\section{Introduction}

Dissolved organic carbon (DOC) plays an integral role in biogeochemical cycling in aquatic ecosystems because it provides an energy source for aquatic organisms, alters pH, affects light penetration, and binds elements [Maranger and Pullen, 2003; Laudon et al., 2004]. Streams can supply a large amount of DOC to downstream ecosystems [e.g., Schindler et al., 1997], and much of the spatial variability in riverine DOM concentration and character can be attributed to watershed land cover characteristics such as percentage of wetland cover, wetland type, and agricultural land use [Gergel et al., 1999; Frost et al., 2006; Wilson and Xenopoulos, 2008; Yamashita et al., 2011]. However, streams are not simply conduits from terrestrial environments to downstream ecosystems [Bernhardt et al., 2005]; in-stream processing of terrestrial DOC can transform or mineralize terrestrially-derived organic $\mathrm{C}$ before it reaches downstream ecosystems [Frazier et al., 2005; Hall and Meyer, 1998; Butman and Raymond, 2011]. Photodegradation and autochthonous production of DOM in aquatic systems can also alter the quantity and chemical composition of DOM [Kaplan and Bott, 1982; Larson et al., 2007], further contributing to spatial variability of DOM composition.

Variation in DOM composition among watersheds is important because it may determine the biodegradability of the DOC (BDOC) pool that is found within or exported from rivers, and biodegradability will determine the ultimate fate of DOC - e.g., whether it is respired by microbes and released as $\mathrm{CO}_{2}$ or stored in freshwater or marine ecosystems. DOM composition has been linked with BDOC across a wide range of ecosystems including temperate soils [Marschner and Kalbitz, 2003] and freshwater and marine ecosystems [Benner, 2003]. For example, some studies suggest that some humic 
fractions of DOM may be important contributors to BDOC [Moran and Hodson, 1990; Volk et al., 1997]. However, a wide range of low molecular weight humic substances with varying susceptibility to degradation can be found in aquatic ecosystems and their contributions to the BDOC pool may also vary. Furthermore, proteins, carbohydrates, and organic acids have also been linked with high BDOC [Marschner and Kalbitz, 2003].

Temperate rivers alone account for $23 \%$ of global total organic carbon export, trailing only tropical rivers [Meybeck, 1982], yet we know little about how composition and biodegrability of that carbon may vary temporally. Although studies have shown the BDOC in temperate streams may differ depending on season [Coble et al. in review] or over several months [Volk et al., 1997], we lack a comprehensive understanding of how $\mathrm{BDOC}$ varies at the week to month scale across an entire year in these streams and rivers. In contrast, studies of temporal variability in BDOC in Arctic rivers demonstrated a high fraction of labile DOC was exported during winter and the spring freshet and attributed this variability to changes in $\mathrm{N}$ availability, DOM chemical composition, and flowpaths [Holmes et al., 2008; Wickland et al., 2012]. We may expect distinct seasonal patterns in BDOC in northern temperate regions versus those observed in arctic systems due to differing rates of winter and spring DOM processing and hydrologic flowpaths. In the arctic during the spring freshet, frozen soils can restrict runoff to surface or shallow soil flowpaths, which allows runoff to leach the upper organic rich layers [Striegl et al., 2005; Finlay et al., 2006]. By comparison, in northern temperate regions without permafrost, shallow flowpaths also persist during snowmelt [Kendall et al., 1999] and deep snowpack can insulate temperate soils during the winter [Stottlemyer,1987; Stottleyer and 
Rutkowski, 1990], preventing soil freezing and allowing winter microbial processing of organic matter beneath the snowpack.

Alterations in the intensity or quantity of freeze thaw cycles, as are predicted for this region in climate projections [e.g. Henry, 2008], can alter soil DOM pools [Schmitt et al., 2008] and subsurface flowpaths [Stottlemyer and Toczydlowski, 2006] in temperate forests, which should influence stream DOM composition and BDOC. Following a severe soil freeze event in Hubbard Brook, the watersheds retained more $\mathrm{NO}_{3}$ than in previous years [Judd et al., 2011] suggesting future climate change may, at least in part, alter watershed $\mathrm{N}$ dynamics, which could influence biodegradability of DOC. Projected future alterations to the intensity [e.g. Groisman et al., 2004] or type of precipitation [snow vs. rain; e.g. Mortsch and Quinn, 1996] received in northern temperate regions may also have consequences for quantity, quality, and timing of DOC entering rivers. It is possible that some of these changes are already underway, although they are likely to accelerate into the future.

The overall goal of our study was to examine how variability in DOC sources may alter the biodegradability of DOC in northern temperate aquatic ecosystems, and how these changes may alter seasonal patterns of DOC in a changing climate. We measured DOC concentrations and conducted short (28 day) incubations approximately monthly over a full year to determine DOC biodegradability and estimate annual DOC and BDOC export in three temperate hardwood forested rivers that vary in watershed size by three orders of magnitude. Our specific objectives were to: 1) determine the percent of total annual DOC exported from these 3 rivers to Lake Superior that is present in biodegradable form and whether biodegradability varies temporally, 2) determine how 
DOM composition affects BDOC in these rivers; and 3) quantify current and historical total annual DOC export from these rivers to Lake Superior.

\section{Methods}

\subsection{Study Sites}

All three study tributaries are located on the south shore of Lake Superior in Michigan's Upper Peninsula (Figure 3). Calumet watershed is located in Houghton County, drains a $1.76 \mathrm{~km}^{2}$ watershed area [Stottlemyer and Toczdylowski, 2006], and comprises $0.001 \%$ of Lake Superior's drainage area (total drainage area for Lake Superior 127,700 $\mathrm{km}^{2}$ ). The Salmon Trout River is located in Marquette County, drains a $127 \mathrm{~km}^{2}$ watershed area [Bullen 1988], and comprises approximately $0.1 \%$ of Lake Superior's drainage area. The Ontonagon River is located in Ontonagon County Michigan, drains a 3,470 $\mathrm{km}^{2}$ watershed area [Thompson, 1978], and comprises $2.6 \%$ of Lake Superior's drainage area. In this region mean annual precipitation is $\sim 80 \mathrm{~cm}$ (National Atmospheric Deposition Program (NADP), station MI99, Chassell Michigan, available from: http://nadp.sws.uiuc.edu.data/) with up to 50\% received as snow [Stottlemyer and Toczdylowski, 2006]. Bedrock within Calumet watershed is comprised of Freda sandstone, Copper Harbor conglomerate and Nonesuch formation, within the Salmon Trout watershed bedrock includes: Archean granitic and gneissic, Michigamme formation, and Jacobsville sandstone, and within the Ontonagon watershed bedrock includes: Jacobsville sandstone, Michigamme formation, and granite and gneissic 
bedrock. Wetland area within each watershed is: Calumet watershed: $30 \%$, Salmon Trout River: 9.9\%, and Ontonagon River: 20\%.

\subsection{Sample Collection and Analysis}

To determine DOC biodegradability we collected stream water twice per season at each of the three tributaries. In spring we collected stream water on two additional dates for a total of four dates because we expected that BDOC may change rapidly during spring snowmelt and runoff [e.g. Wickland et al., 2012]. For these four spring dates, we targeted two collections on the rising limb or at the peak of the hydrograph and two collections on the falling limb, which was achieved at the Calumet and Ontonagon watersheds, while we only captured the falling limb at the Salmon Trout River (Figure 4).

On each sampling date, stream water was filtered within 4 hours of collection, and then stored at $4^{\circ} \mathrm{C}$ until the experiment was set up, which occurred within 24 hours. An additional sample was filtered on site for analysis of DOC concentration and characterization. Initial stream water temperature, conductivity, $\mathrm{pH}$, turbidity, and dissolved oxygen were measured by deploying a YSI 6920 multiparameter sonde (YSI Incorporated, Yellow Springs, Ohio) in the streams on each sampling date. Because inorganic nutrients have been previously linked with BDOC [e.g. Wickland et al., 2012, Coble et al. in review], we also collected water samples to measure dissolved inorganic nitrogen (DIN) concentrations as ammonium $\left(\mathrm{NH}_{4}\right)$ and nitrate $\left(\mathrm{NO}_{3}\right)$, and phosphorus as soluble reactive P (SRP) and total P (TP). Finally, we collected stream sediment from each site by extracting three $1 \mathrm{~cm}$ deep cores $(2 \mathrm{~cm}$ diameter) from the stream channel to use as a microbial inoculum for the BDOC incubations as described below. 
DOC and total dissolved nitrogen (TDN) concentrations were determined using a TOC-5000A analyzer (Shumadzu Scientific Instruments, Columbia Maryland). $\mathrm{NH}_{4}$ analyses were conducted on a Turner Trilogy fluorometer (Turner Designs, Palo Alto, California) and followed Taylor et al. [2007], adapted from Holmes et al. [1999]. Nitrate was analyzed on a Dionex ICS-900 Ion Chromatograph (Dionex, Sunnyvale California). SRP analyses were conducted using the ascorbic acid method [APHA, 2005] on a Thermo Scientific 10s UV-Vis spectrophotometer. Total P analysis followed the same analysis as SRP preceded by an ammonium persulfate digestion [APHA, 2005].

\subsection{BDOC}

To determine DOC biodegradability, 28 day laboratory incubation experiments were conducted by placing $50 \mathrm{~mL}$ of stream water filtered through $0.45 \mu \mathrm{m}$ nylon membrane filters into 15 replicate $100 \mathrm{~mL}$ amber glass serum bottles for each site on each date. A mixture of unfiltered stream water and stream sediment collected from each site on each date was used as a common inoculum, and $1 \mathrm{~mL}$ of inoculum was added to each bottle to introduce a microbial assemblage from the water column and from the benthos [e.g., Coble et al. in review]. The inoculum was site- and date-specific to better mimic in situ stream conditions and to account for seasonal variability in the microbial assemblage.

The serum bottles were sealed, and then $\mathrm{CO}_{2}$ was analyzed for all bottles in $1 \mathrm{~mL}$ aliquots of equilibrated headspace using gas chromatography (model SRI 8610C; He carrier gas; Hayesep D packed column; column temperature $62^{\circ} \mathrm{C}$ ). Calibration curves were created with five standard dilutions of $1000 \mathrm{ppm} \mathrm{CO}_{2}$ standard (Scotty analytical gas, Supelco Analytical, Bellefonte PA). To calculate $\mathrm{CO}_{2}$ concentrations we used $\mathrm{CO}_{2}$ 
equilibrium constants and corrections for temperature and pressure [Plummer and Busenberg, 1982; Striegl et al., 2001]. The volume of headspace removed was replaced with an equal amount of $\mathrm{N}_{2}$.

Following the initial $\mathrm{CO}_{2}$ measurements on day 0 , three replicate bottles per stream were acidified with $2 \mathrm{~mL} 43.5 \% \mathrm{H}_{3} \mathrm{PO}_{4}$ and the headspace was analyzed for dissolved inorganic carbon (DIC) by measuring $\mathrm{CO}_{2}$ as described above. Three additional replicate bottles per stream were analyzed for DOC concentration as described above and DOM composition as described below. The 9 remaining bottles per stream were then placed on a shaker table in the dark at a temperature of $21^{\circ} \mathrm{C}$ to control for temperature among seasons. After 28 days, all replicate bottles were analyzed for headspace $\mathrm{CO}_{2}$ concentrations, then six replicates were acidified and analyzed for DIC, and the final three replicates were analyzed for DOC concentration and composition. For each incubation, the percent BDOC (hereafter referred to as BDOC) was calculated as follows [Wickland et al., 2012]:

$$
\text { BDOC }=\frac{\text { DIC }_{\text {final }}-\text { DIC }_{\text {initial }}}{\text { DOC }_{\text {initial }}}
$$

Three of the BDOC values (Salmon Trout River January 2014, Calumet Watershed July 2014, and Ontonagon River July 10, 2014) were negative, but standard error estimates suggest these values are within the range of $0 \% \mathrm{BDOC}$ and therefore below our detection ability using these assays.

To determine if BDOC varied temporally, we conducted a repeated measures analysis of variance (rm ANOVA) for each stream with date as the repeated factor and BDOC as the response variable with SAS version 9.4 (SAS Institute, Cary, North Carolina, USA). BDOC data were arcsin transformed to meet assumptions of normality. 
Because we were unable to sample the Ontonagon River in winter we conducted two separate rm ANOVA analyses 1) excluding Ontonagon River samples; 2) excluding winter samples to determine whether BDOC varied among sample dates or sites. For all statistical analyses alpha was set a priori at 0.05 .

\subsection{DOC characterization and PARAFAC modeling}

We characterized DOM character using UV-Vis spectrophotometric and fluorescence methods. Specific ultraviolet absorbance at $254 \mathrm{~nm}\left(\mathrm{SUVA}_{254}\right)$, an indicator of C aromaticity, was measured using a GENESYSTM 10s UV-Vis spectrophotometer (Thermo Scientific, Waltham, Massachusetts), and determined by dividing the UV absorbance at $254 \mathrm{~nm}$ wavelength by the DOC concentration [Weishaar et al., 2003]. Fluorescence excitation-emission matrices (EEMs) of stream water and incubation samples were determined with a Horiba Aqualog (Jobin Yvon Horiba, France) at $3 \mathrm{~nm}$ excitation wavelength intervals between 240 and $600 \mathrm{~nm}$, and at emission wavelength coverage between 212 and $620 \mathrm{~nm}$ with $3.28 \mathrm{~nm}$ increments. Fluorescence spectra were corrected for inner filter effects, accounting for the absorption of both emission and excitation light by the DOM sample. To remove the Raman signal, a Raman-normalized Milli-Q water sample was removed from each fluorescence spectrum. All EEMs are then expressed in Raman Units (R.U.; nm ${ }^{-1}$ ). Fluorescence index (FI), which distinguishes between microbial and terrestrial-derived sources, was identified from corrected EEMs as the ratio of the emission intensity at $450 \mathrm{~nm}$ to $550 \mathrm{~nm}$ acquired with an excitation of $370 \mathrm{~nm}$ [McKnight et al., 2001]. 
In addition, fluorescence EEMs were analyzed using the multivariate modeling technique parallel factor analysis (PARAFAC), a three way decomposition method [Stedmon et al., 2003]. PARAFAC modeling was completed using MATLAB software $\left(\right.$ MATLAB $^{\circledR}$, The Mathworks, Natick, USA) and the PLS-toolbox (Eigenvector Research Inc., Wenatchee, WA USA) on 374 samples collected in Michigan's Upper Peninsula comprised primarily of river samples, but also including near-shore Lake Superior samples, snow samples, and soil lysimeter samples from study sites. This analysis validated six components, and split-half analysis following Stedmon et al. [2003] and Stedmon and Bro [2008] revealed that splits were 92.5\% similar. All of the six components identified by the model have been previously described for aquatic systems (Table 1). Component 1 (C1) was identified as a fulvic-like peak, and components 2 (C2), 3 (C3), and 5 (C5) were identified as humic-like peaks (Table 3). Component 4 (C4) was identified as humic-like and fulvic-like (Table 3). One protein-like component, component 6 (C6), was identified as tryptophan in our data set, but tyrosine, another protein-like component commonly observed in aquatic ecosystems, was not identified. The fluorescence intensity of each component is expressed as a percentage of the total intensity of all components identified.

\subsection{Multivariate analysis of BDOC and DOM character}

To determine how DOM composition affects DOC biodegradability, we first used a principal components analysis (PCA) to examine relationships among the six fluorescence components identified by PARAFAC and other measurements of DOC characteristics including: FI, SUVA 254 , and [DOC]. For this analysis we included only stream water samples from day 0 of the incubation. To further identify which DOC 
characteristics influenced BDOC across sites and dates, we used a partial least squares (PLS) with BDOC (y response variable) and all of the measured DOC characteristics ( $\mathrm{x}$ predictor variables). The importance of each $\mathrm{X}$ variable was determined by the variable importance on the projection scores (VIP) with a value $\geq 1$ considered highly influential, between 0.8 and 1 as moderately influential, and $<0.8$ as less influential. Cross validation of the data set was performed with 10 splits. The number of components included in the model was determined by assessing eigenvalues and the root mean square error of the cross validation (RMSECV). Outliers were identified using the Hotelling's $\mathrm{T}^{2}$ analysis if they exceeded the $95 \%$ confidence limit. PCA and PLS analyses were performed using MATLAB (MATLAB ${ }^{\circledR}$ ) with the PLS Toolbox (Eigenvector Research Inc., Wenatchee, WA USA). Following PLS analysis, we used linear regression to test for relationships between BDOC and the most influential components identified with the PLS model. We also explored the relationship between BDOC and [DOC]:[DIN] using linear regression [c.f., Wickland et al., 2012].

\subsection{Load modeling and time series analysis}

To quantify current and historical DOC export from streams to Lake Superior we calculated annual DOC loads from the 3 study tributaries. Water samples to measure DOC concentrations were collected at least monthly across a variety of flow and environmental conditions. At the Ontonagon River, we were unable to collect water during the winter because ice cover prevented safe access to the water column. The other two study rivers were also ice covered during the winter, but we were able to safely 
access the water beneath the ice. Samples were filtered and analyzed for DOC and TDN concentrations, $\mathrm{SUVA}_{254}$, and FI as described above.

To calculate the total annual and monthly DOC loads from these Lake Superior tributaries we used the FORTRAN load estimator (LOADEST) program [Runkel et al., 2004]. LOADEST requires at least 12 measurements of DOC concentrations, thus we used $>12$ measurements of DOC at each site to calibrate the LOADEST model. Additionally, we used daily discharge measurements from each site to calculate monthly and annual loads.

Discharge at Calumet watershed is continuously monitored with a Parshall flume, Stevens pressure transducer (Stevens Water Monitoring Systems Inc., Portland, Oregon) and Li-Cor datalogger (Li-Cor, Lincoln, Nebraska) installed at the site [Stottlemyer and Toczdylowski, 2006]. Discharge of the Salmon Trout and Ontonagon Rivers is gauged by the USGS (http:/waterdata.usgs.gov); discharge records were obtained for station 04043238, located in the headwaters of the Salmon Trout River, and for station 04040000, located on the Ontonagon River near Rockland, MI. Our study location at the Salmon Trout River was downstream of the gauging station; to relate discharge at the downstream site to the upstream USGS discharge measurements, we deployed a level logger downstream and measured discharge under a variety of flow conditions to identify the time lag between upstream and downstream discharge measurements. To measure discharge we set up a transect [Gordon et al., 2004] and measured velocity in at least 10 locations along the transect using a Flomate flow meter and wading rod. During high flow conditions (e.g., spring runoff) discharge was measured with a StreamPro Acoustic Doppler Current Profiler (ADCP; Teledyne RDI, Poway, California). A logarithmic 
regression of discharge measurements from 2012 through 2014 was used to estimate discharge downstream based on the upstream gauge data $\left(\mathrm{Q}_{\text {downstream }}=82.484 *\right.$ $\ln \left(\mathrm{Q}_{\text {upstream }}\right)$ - 89.519, $\left.\mathrm{n}=20, \mathrm{r}^{2}=0.49, \mathrm{p}=0.0006, \mathrm{~F}_{(1,18)}=17.46\right)$.

To estimate BDOC loads from the study rivers we multiplied the monthly loads of DOC obtained from LOADEST by the BDOC measured within that month. When $\mathrm{BDOC}$ was not measured in that month then the nearest month or an average of the nearest months were applied. The BDOC values were applied within the season it was measured. The August stormflow BDOC measurement was not applied to the August estimate, but was applied to specific days when stormflow events occurred in summer and fall as identified by examining the hydrograph.

To calculate historical DOC loads from Calumet watershed we used water chemistry and stream flow data that have been collected continuously from 1988 to 2014 [Stottlemyer and Toczdlowski, 2006]. We applied current BDOC measurements to historical DOC load estimates to estimate historic BDOC loads, assuming that the proportion of the DOC load that is biodegradable has remained constant through time. We used LOADEST to estimate load contributions for each one-year period. Thus, the model was calibrated independently for each year to facilitate analysis of temporal variability.

To examine the rate and trajectory of change in monthly DOC and BDOC loads from Calumet watershed through time we used a univariate autoregressive integrated moving average (ARIMA) model [Box and Jenkins, 1970]. Time-series analysis is more appropriate than regression to analyze data with temporal autocorrelation. ARIMA modeling was conducted on: 1) monthly DOC loads from July1988 through June 2014; 
and 2) monthly BDOC from July 1988 through June 2014. Additionally, we analyzed mean seasonal loads separately because previous research at our study site found an increase in winter/spring loads suggesting there may be seasonal differences in DOC export over time [Stottlemyer and Toczdlowski, 2006]. Seasons were defined as: Summer $=$ June, July, August; Fall = September, October, November; Winter $=$ December, January, February; Spring = March, April, May. For this analysis we averaged the three months for each season to obtain a single value for each year. Seasonal ARIMA model structure is denoted by $(p, d, q)(P, D, Q)[m]$ where $p=$ nonseasonal number of autoregressive parameters, $\mathrm{d}=$ non-seasonal order of differencing, $\mathrm{q}$ $=$ non-seasonal number of moving average parameters, $\mathrm{P}=$ seasonal number of autoregressive parameters, $\mathrm{D}=$ seasonal order of differencing, $\mathrm{Q}=$ seasonal number of moving average parameters, $\mathrm{m}=$ number of periods per season. The data were assessed for stationarity (constant mean, variance and autocorrelation); if data are non-stationary then the data must be detrended by differencing [Cryer and Chan, 2008]. Models were assessed by examining autocorrelation and partial autocorrelation plots to ensure the model had accounted for all autocorrelation [e.g. Zuur et al., 2009], and final model selection was determined by Akaike Information Criterion [AIC; Akaike, 1973]. All ARIMA modeling was completed using $\mathrm{R}$ (version 3.1.2, $\mathrm{R}$ core development team) using the Arima function [R package forecast; Hyndman; 2013]. 


\section{Results}

\subsection{Biodegradable DOC Incubations: Spatial and Temporal Variability}

BDOC in these streams exhibited temporal variability, and some of this variability occurred within seasons (Figure 5). Summer measurements of BDOC ranged from negligible (Calumet Watershed and Ontonagon River, 10 July 2014), to moderate (all sites, 2 July 2013), to exceptionally high during a summer storm event (all sites, 26 August 2013). The greatest BDOC value overall was observed during the summer storm event in the Ontonagon River. While BDOC was also elevated during this storm at the other two sites, the greatest BDOC at the Salmon Trout River and Calumet Watershed occurred in winter, on 28 February 2014. However, BDOC was low to negligible a month earlier at both sites on 15 January 2014, in spite of ice cover over both rivers from December until late April. Within-season variability in BDOC was not as pronounced in fall and spring. From October to November there was an increase in BDOC at the smallest and largest watersheds (Calumet and Ontonagon), but a decline in BDOC in the intermediately-sized watershed (Salmon Trout). We did not observe a relationship between BDOC and position on the hydrograph during spring snowmelt; however, we were unable to capture the rising and falling limb at all sites due to variability in the timing of snowmelt and amount of snow among these three watersheds (Figure 4). Pearson correlation coefficients of BDOC among sites suggest that BDOC is synchronous across sites (Calumet and Ontonagon: $\mathrm{r}=0.89, \mathrm{p}=0.001$; Salmon Trout and Ontonagon: $\mathrm{r}=0.87, \mathrm{p}=0.003$; Calumet and Salmon Trout: $\mathrm{r}=0.87, \mathrm{p}<0.001$; Figure 6). Analysis of BDOC among sample dates revealed significant effects of site and date, and a significant interaction of site $\mathrm{x}$ date when the Ontonagon River was excluded (site 
$\left(\mathrm{F}_{(1,38.7)}=32.81, \mathrm{p}<0.001\right)$, date $\left(\mathrm{F}_{(10,37.4)}=54.31, \mathrm{p}<0.001\right)$, site $\mathrm{x}$ date $\left(\mathrm{F}_{(10,37.4)}=16.72\right.$, $\mathrm{p}<0.001)$ and when winter was excluded ( $\operatorname{site}\left(\mathrm{F}_{(2,47)}=47.0, \mathrm{p}<0.001\right)$, date $\left(\mathrm{F}_{(8,51.1)}=\right.$ $131.70, \mathrm{p}<0.001)$, site $x$ date $\left(\mathrm{F}_{(10,37.4)}=16.72, \mathrm{p}<0.001\right)$.

The three sites showed similar temporal patterns in discharge, temperature, and conductivity (Appendix Table 1). Inorganic N and SRP values were often below our detection limit (Appendix Table 2). DOC concentrations ranged from 5.63 to $18.96 \mathrm{mg}$ $\mathrm{L}^{-1}$ at Calumet Watershed, 2.73 to $11.14 \mathrm{mg} \mathrm{L}^{-1}$ at the Salmon Trout River, 7.85 to 14.85 $\mathrm{mg} \mathrm{L}^{-1}$ at the Ontonagon River (Appendix Table 2).

\subsection{DOM composition}

\subsubsection{Relationships among DOM concentration and composition}

The PCA of DOC concentration and DOM composition metrics resulted in four principal components that together explained $94 \%$ of the variance in DOM. The first two principle components alone explained $78 \%$ of the variance in DOM. Loadings for the first PCA axis, which explained $65 \%$ of the variability in the model, were most strongly positively affected by $\mathrm{C} 4$ (humic-like), $\mathrm{C} 1$ (fulvic-like), DOC concentration, and C5 (humic-like) and negatively by C2 (humic-like; Appendix Figure 1). Loadings for the second PCA axis, which explained $13 \%$ of the variability in the model, were positively affected by C3 (humic-like fluorophore) and negatively by C6 (tryptophan-like fluorescence), indicating a gradient from allochthonous to autochthonous influence.

\subsubsection{Predictors of BDOC}

We used a PLS analysis and subsequent linear regression to determine the influence of DOC characteristics on riverine BDOC across all sites and dates. The PLS 
model provided information about potential factors affecting BDOC and identified 4 latent variables (LV); Table 4). The model explained $88 \%$ of the variability in the DOM composition (X variables) and $17 \%$ of the variability in BDOC ( $\mathrm{Y}$ variable). The model's ability to fit the data $(\mathrm{RMSEC}=12.49)$ was similar to the model's ability to predict samples that were not used in model building (RMSECV $=15.39$; [Wise et al., 2006]. Analysis of Q residuals (11.8\%) and Hotelling $\mathrm{T}^{2}$ value (88.2\%) indicate each sample conformed well to the model and revealed little variation in each sample within the model [Wise et al., 2006].

To best illustrate the differences among DOM composition (X variables) we display only two LVs, LV1 and LV2. The first component (LV1) explained 64\% of the variability in $\mathrm{X}$ variables (DOM composition), $6 \%$ of the variability in the $\mathrm{Y}$ variable (BDOC), and represented a gradient of aromaticity; DOC concentration, $\mathrm{SUVA}_{254}, \mathrm{C} 1$, C4, and C5 (humic and fulvic like-fluorophores) had negative loadings and C2, C3 (humic-like fluorophores), C6 (tryptophan-like fluorophore), and FI had positive loadings (Figure 7). The second component axis explained $15 \%$ of the variability in $\mathrm{X}$ variables and $7 \%$ of the variability in the $\mathrm{Y}$ variable and represented a gradient from a humic-like fluorophore (C3) to a tryptophan-like fluorophore (C6; Figure 7).

Based on VIP scores, C6 and C1 (ordered from greatest to least VIP score) were identified as highly influential predictors of BDOC in the model, $\mathrm{SUVA}_{254}$ and $\mathrm{C} 3$ were moderately influential, and all other variables were less influential (Figure 7). Of these highly influential predictors, tryptophan-like fluorescence (C6) was positively related to BDOC shown by its positioning near BDOC on the PLS bi-plot and the fulvic-like fluorophore $(\mathrm{C} 1)$ was negatively related to $\mathrm{BDOC}$ shown by their positioning opposite 
BDOC on the PLS bi-plot (Figure 7). Linear regression analysis indicated that individually none of the components (C1-C6), DOC concentration, SUVA 254 , FI, nor [DOC]:[DIN] were significant predictors of BDOC (Table 3). DOC concentration, $\mathrm{SUVA}_{254}, \mathrm{FI}$, and [DOC]:[DIN] were not significant predictors of BDOC (Table 5). Collectively these analyses reveal limited predictive ability of BDOC by these DOM composition variables reflecting relative aromaticity and autochthony.

\subsubsection{Temporal variability in DOM concentration and composition}

The PLS analysis also provides insight into how the composition of DOM relative to BDOC changed through time in the 3 study rivers. During summer base flow, DOM composition shifted from greater fulvic and humic-like fluorophores (C4, C1, C5), DOC concentration, and aromaticity (SUVA 254 ) in July 2013 to greater humic-like fluorophore (C2, C3), FI, and tryptophan-like fluorescence (C6) in July 2014 (Figure 8a), which was associated with a decline in BDOC from July 2013 to July 2014 (Figure 5). DOM composition during the summer storm flow event was distinct for each of the three sites, with all sites spread from smallest to largest along the first axis (LV1, Figure 6 along a gradient of decreasing $\mathrm{C} 4, \mathrm{C} 1, \mathrm{C} 5, \mathrm{DOC}$, and aromaticity, and increasing $\mathrm{C} 2, \mathrm{C} 3, \mathrm{C} 6$ and FI. However, despite the high degree of variability in composition expressed along the LV1 axis, similarly high BDOC values were observed across all three sites during this storm event (Figure 5).

In fall, DOM composition shifted along LV 1 toward greater $\mathrm{C} 4, \mathrm{C} 1, \mathrm{C}$, DOC, and aromaticity from 13 October 2013 to 14 November 2013, and also shifted towards greater \% tryptophan along LV2 (Figure 8b), which was associated with an increase in BDOC at Calumet Watershed and the Ontonagon River and a decrease at the Salmon 
Trout River. At Calumet winter DOM composition was similar to the fall season. At the Salmon Trout River winter DOM had greater humic-like fluorescence (C2), FI, and \%tryptophan (C6) observed along LV1 and greater C6 (tryptophan) observed along LV2 relative to fall (Figure 8c). Despite the similar DOM composition among winter measurements, winter BDOC was variable with extremely high and low BDOC observed.

In spring, all sites were found on the negative side of LV1, indicating DOM was comprised of greater $\mathrm{C} 4, \mathrm{C} 1, \mathrm{C} 5, \mathrm{DOC}$, and aromaticity for all sites except for the Salmon Trout River in late May, suggesting that DOM composition in that river had returned to similar composition observed during baseflow (Figure 8d). All other sites and dates revealed markedly similar positioning along LV1 across spring dates and varied mainly along the LV2 axis suggesting that the amount of tryptophan (C6) versus humiclike fluorescence (C3) varied among dates. Consistency in DOM composition among spring dates concurs with the consistent BDOC values observed for all study sites and dates (Figure 5).

\subsection{DOC and BDOC loads}

As expected, magnitudes of the annual DOC and BDOC loads from these three rivers in 2013-2014 were reflective of watershed size and annual discharge (Table 6). The 2013-2014 DOC load at Calumet watershed was on the higher end of the range in DOC loads observed at this site since 1988 (Figure 9). A majority of the annual DOC loads were exported in the months of April and May, which alone comprised $62.9 \%$ of total annual DOC loads at Calumet watershed, $43.3 \%$ at the Salmon Trout River, and $62.5 \%$ at the Ontonagon River. Annual loads of BDOC exported from each of these rivers ranged from 422 to $2,788,000 \mathrm{~kg} \mathrm{C} \mathrm{yr}^{-1}$ (Table 6). The percent of the annual DOC 
load that was biodegradable was comparable for the two larger rivers $(17 \%$ and $16 \%)$ and lower for the smallest river (9\%). We estimated that collectively, the three rivers

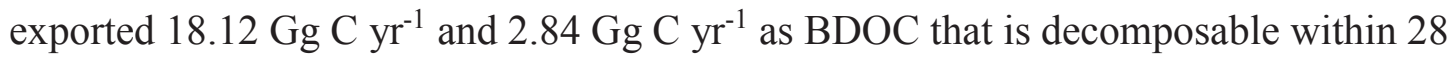
days, which corresponds with $15.7 \%$ of annual export from these tributaries (Table 6).

The selected ARIMA model of monthly DOC loads at Calumet Watershed from 1988 to 2014 required no differencing and suggests that the model is stationary at the annual time scale over the observed period $(\operatorname{ARIMA}(0,0,0)(1,0,1)[12]$; Table 7$)$.

Similarly, the selected ARIMA model for monthly BDOC loads from 1988 to 2014 was $\operatorname{ARIMA}(0,0,0)(1,0,1)[12]$ and suggests that the model is stationary at the annual timescale (Table 7). Both DOC and BDOC loads display clear seasonal patterns with loads peaking each spring (Figure 9). BDOC loads followed similar patterns to DOC (Figure 9). DOC loads became more variable after 1996 when loads exceeded $1500 \mathrm{~kg}$ $\mathrm{mo}^{-1}$ in some years (Figure 9). ARIMA models of mean seasonal loads indicated the same model structure $(\operatorname{ARIMA}(0,1,1)$ with drift) for each of the four seasons, which indicates one order of differencing which suggest the data had a constant rate of change within each season (Table 8; Figure 10). The drift components indicate an increasing trend in DOC loads over time for 3 seasons, but a decreasing trend in DOC loads over time within the fall season (Table 8).

\section{Discussion}

BDOC appears to vary synchronously across three northern temperate rivers despite large variability in watershed size and location. DOM composition, particularly compounds containing tryptophan and humic-like fluorophores, was identified as a 
predictor of BDOC but only explained a small amount of the total variation in BDOC.

The synchronous pattern of BDOC cannot be explained by DOM composition alone; for example, we observed large variation in DOM composition among study sites during a summer storm event described by fluorometric and spectrophotometric indices, however we observed very little variation in BDOC among these rivers on any given date. On average, $14 \%$ of $\mathrm{C}$ that is exported to Lake Superior from these rivers is relatively labile and large contributions of labile $\mathrm{C}$ can be exported during much of the year, particularly during stormflow events. Historical load modeling over a 26 year period suggest that loads of DOC and BDOC are increasing in the spring during snowmelt, and that DOC and BDOC loads are not consistently increasing at an annual time scale. Given this apparent dependence of BDOC on hydrologic events like stormflow and spring runoff, future changes in climate that alter the timing of seasons or increase the frequency or severity of storms may alter the quantity and timing of BDOC exported from temperate rivers, with potential consequences for productivity in downstream rivers, lakes, and oceans.

\subsection{DOM composition and synchronous biodegradability of DOC}

Consistent with previous studies of riverine DOM [Fellman et al., 2010a, Mann et al., 2012, Wickland et al., 2012], we found DOM composition was an influential predictor of $\mathrm{BDOC}$, but it explained only $17 \%$ of the variability in BDOC across these rivers. Evidence from several studies has indicated that terrestrially-derived humic DOM may be an important component of the stream BDOC pool [Moran and Hodson, 1990, Volk et al., 1997]; however, in our study we did not find humic fluorophores to strongly influence variability in BDOC although a fulvic flourophore was an influential predictor. 
Tryptophan-like fluorescence, the only autochthonous DOM source identified in our PARAFAC model, was also an influential predictor of BDOC which is consistent with previous studies [Fellman et al., 2009a; Balcarczyk et al., 2009; Wickland et al., 2012,]. In contrast to previous studies [e.g. Wickland et al., 2012], we did not find any relationships between $\mathrm{BDOC}$ and nutrient concentrations, $\mathrm{SUVA}_{254}$ (an indicator of C aromaticity) or FI (an indicator of sources of fulvic acids). Therefore, the majority of the variability (79\%) of BDOC in our study cannot be accounted for by DOM composition, source, or stoichiometry.

DOM composition was remarkably similar among watersheds that vary in size by orders of magnitude and in wetland area (10 to 30\%). However, DOM composition during a summer storm event was extremely variable among watersheds, and our results demonstrate that a wide range of DOC concentrations, \% protein like fluorophores, and $\%$ humic like fluorophores can yield high BDOC during storm events across a range in river sizes. In contrast, another study measuring BDOC during storm events did not find that different DOM composition yielded similar responses of BDOC [Fellman et al., 2009b] nor did storm events yield variability in DOM composition among streams [Singh et al., 2014]. Singh et al. [2014] investigated the effects of stream size on DOM composition during storm events and found that DOM composition was similar across a narrow range of stream sizes in nested watersheds $\left(0.035\right.$ to $\left.0.79 \mathrm{~km}^{2}\right)$. Apparently a greater range in river size and spatial independence among rivers led to greater variability in DOM composition among our study rivers during a storm event. McGuire et al. (2005) found that flowpath length and gradient were correlated with residence time and that these topographic characteristics influenced watershed scale transport more than 
watershed size. We suggest that perhaps storm events allow for differences in flow paths and residence times among watersheds (e.g. McGuire et al. 2005; Uchida et al. 2006) to become more pronounced because at other times of the year DOM composition was remarkably similar. Singh et al [2014] suggested that hydrologic flow paths and wetland coverage may also be influential factors for concentration and composition of DOM during storm events. Regardless of the mechanism controlling variability in DOM composition among during storm events biodegradability did not differ, suggesting that DOM may be rapidly decomposed and/or respired by microbes in recipient aquatic ecosystems.

Although the biodegradability of DOC in our study rivers varied minimally as a function of size, it varied greatly as a function of time. Jaffe et al. [2008] analyzed variability in DOM composition as determined from UV-visible absorbance and fluorescence spectra from streams, lakes, and estuaries across 12 Long Term Ecological Research sites distributed throughout the United States. Theyfound that DOM composition varied both temporally at monthly scales in Florida Bay and that DOM composition can vary spatially among biogeographic regions. During fall and spring seasons, consistent nutrient inputs and hydrologic drivers across our study sites (e.g., leaf litter in fall and snowmelt in spring) likely drive the consistency in DOM pool composition across our study rivers except during storm events. Across the three rivers, BDOC followed similar trends, suggesting that temporal variability may exert a greater control over BDOC than watershed size. For example, all sites exhibited minimal BDOC in January and July 2014, maximal BDOC in February and during a summer storm event, and moderate BDOC in spring. In the Yukon River basin in Alaska, 
Wickland et al. [2012] observed similar trends in BDOC among a gradient of river size and suggested that hydrology was an important control on BDOC across river size by minimizing DOM processing during transport. Across our study sites DOM processing is likely also minimized due to cold water temperatures during much of the year and reduced photodegradation due to canopy cover. Seasonal variability in biological factors, such as microbial community composition, or physical factors, such as stream water temperature and light availability, may be more important in determining BDOC than watershed size across these northern temperate forested rivers.

Intriguingly, our data also suggest that similar compositions of DOM can have different biodegradability depending on the time of year. Summer baseflow measurements demonstrate similarities in DOM composition but differences in biodegradability across dates (BDOC was greater in July 2013 than in July 2014). Additionally, autochthonous sources of DOM were most prevalent in winter on both experimental dates in the winter, as indicated by higher $\%$ of tryptophan-like components and higher FI values, yet the biodegradability of DOC varied dramatically between January and February. Other studies measuring BDOC beneath ice in rivers have found the greatest \% tryptophan in their samples occurred in winter in the Yukon River [Wickland et al., 2012] or the pre-spring freshet in the Kolyma River [Mann et al., 2012], but the response of BDOC differed between these two rivers. In the Yukon River the percent BDOC was high (41 to 53\%) but in the Kolyma River BDOC was very low (0.1\%) [Wickland et al., 2012; Mann et al., 2012]. Monthly measurements of chlorophyll a from our smallest study stream, Calumet watershed, indicate an increase in periphytic biomass in winter relative to other seasons [Coble et al., in preparation], suggesting that 
autochthonous production of DOC may be greatest during this season. However, other factors may be important in regulating BDOC during this season, and more intensive sampling and BDOC analysis during the winter months is needed to understand the high amount of variability observed.

\subsection{Fate of terrigenous DOM}

It is important to understand the fate of terrigenous DOM because it is essential for aquatic productivity, energy budgets, and a changing climate. We estimate that annually $14 \%$ of DOC exported from rivers to Lake Superior is biodegradable within 28 days. Despite the elevated BDOC observed in storm event or winter sampling periods, 23 to $73 \%$ of BDOC is exported in spring across these rivers. This is not because the DOC pool is particularly susceptible to biodegradation during this time, but rather because the majority of annual DOC was exported in spring (40 to 63\%) due to high river

discharges. During this snow-melt period, high water velocity leads to low river residence time, suggesting that much of this highly labile $\mathrm{C}$ is likely exported to Lake Superior rather than stored or processed in tributary streams.

It is widely acknowledged that storm-flow events can provide "hot moments" when large DOC pulses occur in rivers [e.g. Raymond and Saiers, 2010], and some studies have shown BDOC also increases during storm events [Kaplan and Newbold, 1995; Buffam et al., 2001]. Our results support the concept that these hot moments are important in exporting not only high quantity DOC but also high quality DOC, and further show that across a range in river sizes a substantial amount of BDOC can be exported from temperate forested watersheds during storm events. 


\subsection{DOC, N, and BDOC loads across the Lake Superior basin}

Annual estimates of DOC and BDOC loads in our three study sites highlight the role of stream size in total DOC export. Clearly, the largest of these rivers accounts for a considerably larger proportion of loads exported from these rivers. Using stream data layers from Michigan, Wisconsin, Minnesota, and Ontario (Canada), we estimate that there are 1550 tributaries surrounding Lake Superior's shorelines (Figure 3). Streams from Isle Royale National Park were not included in the state stream layers and it is likely that many of the smaller first-order streams were not included in these stream layers. Therefore, the actual number of streams may be even greater. Of these 1550 streams, 1544 of them are smaller than the Ontonagon River, the $6^{\text {th }}$ largest tributary of Lake Superior. Thus, DOC and BDOC export in the majority of these streams is likely more reflective of the smaller tributaries included in the current study.

To compare the DOC concentrations and DOM composition of our study sites with other regional streams, we measured DOC concentrations in 33 additional south shore Lake Superior tributaries (not including our three study sites) and found they ranged from 2.0 to $9.30 \mathrm{mg} \mathrm{L}^{-1}$ during baseflow conditions and from 6.46 to $19.42 \mathrm{mg} \mathrm{L}^{-1}$ during spring snow-melt (Appendix Table 4). By comparison, DOC concentrations at our three study sites ranged from 2.73 to $18.96 \mathrm{mg} \mathrm{L}^{-1}$ (Appendix Table 2), and all of our measurements are within the range of previously reported concentrations for Lake Superior tributaries: 2.8 to $34 \mathrm{mg} \mathrm{L}^{-1}$ [Back et al., 2002; Urban et al., 2005; Frost et al., 2006; Minor and Stephens, 2008].

Our study sites represent a relatively small fraction $(\sim 2.8 \%)$ of the total watershed size of Lake Superior $\left(127,700 \mathrm{~km}^{2}\right)$. By making a crude assumption that similar DOC 
and BDOC loads are exported from all Lake Superior tributaries, we scaled our

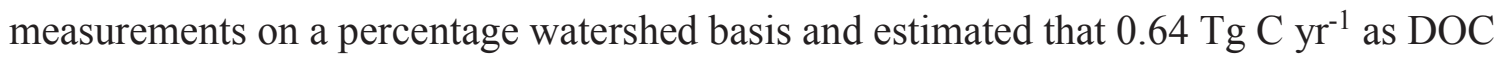

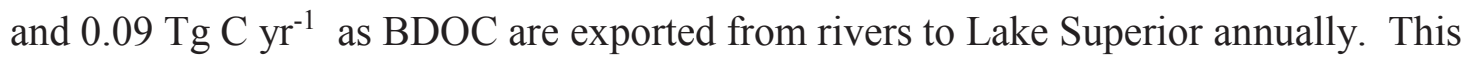
scaled up estimate is within the range of previously estimated riverine export of $\mathrm{C}$ from

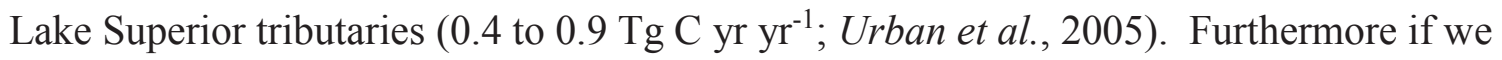
apply the mean of our annual BDOC estimates $(9,17,16 \%$ BDOC; mean $=14 \%)$ observed across the three sites to Urban et al.'s [2005] estimate of C export, together with the assumption that all Lake Superior tributaries exhibit similar percentages of

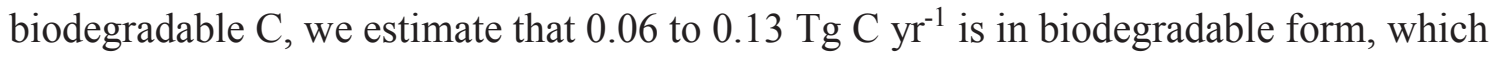
is also consistent with the estimate calculated on a percentage watershed basis above. Our results suggest that a large amount of $\mathrm{C}$ that is exported to Lake Superior is relatively labile, and large contributions of labile $\mathrm{C}$ can be exported during much of the year, particularly during summer stormflow events, late winter, and spring snowmelt. Given the large percentage of $\mathrm{C}$ exported by temperate streams globally, our results suggest large amounts of this $\mathrm{C}$ is likely relatively labile, resulting in pulses of labile DOC exported during storm events or during snowmelt, in regions where snowpack occurs.

\subsection{Historical loads at Calumet watershed and implications for future export}

Long-term monitoring at Calumet watershed has provided a unique dataset of watershed solute export to Lake Superior, and allowed us to compare current measurements of DOC and BDOC to historical records to identify whether previous export has changed over time. Historical annual load modeling of $\mathrm{C}$ suggested that past export of BDOC has not changed over a 26 year period. When modeling historical 
BDOC loads we assumed that seasonal patterns of BDOC have remained constant over time, but with climate change it is likely that these patterns may vary. Exploration of long-term variability within each season individually suggests that there is variability in DOC loads within each season that is not apparent on an annual scale. Stottlemyer and Toczdylowski [2006] previously observed a decrease in the amount of snowmelt over time at Calumet watershed, and future reductions in the quantity or timing of snowmelt may have consequences for stream flow in late summer and fall as water demands from evapotranspiration reduce surface water quantity. If this pattern continues we may expect to further observe a reduction in fall DOC loads as was indicated by the long-term record. The observed long-term increase in winter and spring DOC loads suggests that the winter/spring snowmelt season may be a critical season for biogeochemical change in these aquatic systems, which corresponds to a time of peak BDOC export and unique DOM composition relative to baseflow. Our results suggest that any future increase in spring DOC export will result in greater annual export of BDOC due to the magnitude of DOC export during this season. Substantial snowpack enables belowground soil microbial processing to occur in winter in northern temperate ecosystems, and microbial processing ultimately influences the composition of runoff delivered to rivers [e.g. Semkin et al., 2002]. Projected future changes in the amount of winter precipitation and increases in air temperature may affect the type of precipitation received in winter [Wuebbles and Hayhoe, 2004] and potential for soil freeze-thaw cycles [e.g. Henry, 2008], and any alteration in quantity of snowpack or timing of snowmelt may affect seasonal DOC export and annual BDOC export from rivers. 


\section{Acknowledgements}

Funding for this research was provided by NASA Michigan Space Grant Consortium, U.S.D.A. McIntire-Stennis funding received by Michigan Technological University, a Research Seed Grant from Michigan Technological University’s Research Excellence Fund, the Huron Mountain Wildlife Foundation, and the Michigan Tech Ecosystem Science Center. A.A.C. was also supported with a fellowship from the National Science Foundation's GK-12 Global Watershed program (award DGE0841073). We thank E. Collins, B. Danhoff, K. Heiden, and T. Matthys for assistance in the field and lab, and T. Veverica and K. Meingast for assistance with analysis of fluorescence characteristics. 


\section{References}

Akaike, H. (1973) Maximum likelihood identification Gaussian auto-regressive moving average models. Biometrika, 60, 255-266.

APHA (2005) Standard methods for the examination of water and wastewater. American Public Health Association, American Water Works Association, and Water Environment Federation.

Back, R.C., Hurley, J.P., and Rolfhus, K.R. (2002) Watershed influences on the transport, fate, and bioavailability of mercury in Lake Superior: field measurements and modeling approaches. Lakes Reserv Res Manage, 7, 201-206.

Balcarczyk, K.L., Jones, J.B., Jaffe, R., Maie, N. (2009) Stream dissolved organic matter bioavailability and composition in watersheds underlain with discontinuous permafrost. Biogeochemistry, 94, 255-270.

Benner, R. (2003) Molecular indicators of the bioavailability of dissolved organic matter. In: Aquatic ecosytems interactivity of dissolved organic matter. Editors: Findlay S.E., and Sinsabaugh R.L. Academic Press, San Diego

Bernhardt, E.S., Likens, G.E., Hal, R.O., Buso, D.C., Fisher, S.G., Burton, T.M., Meyer, J.L., McDowell, W.H., Mayer, M.S., Bowden, W.B., Finslay, S.E.G., Macneale, K.H., Stelzer, R.S., and Lowe, W.H. (2005) Can't see the forest for the stream? Instream processing and terrestrial nitrogen exports. Bioscience 55(3), 219-230.

Box, G., and Jenkins, G.M. (1970) Time series analysis: forecasting and control. HoldenDay, San Francisco, California 
Buffam, I., Galloway, J. N., Blum, L. K., and McGlathery, K. J. (2001) A stormflow/baseflow comparison of dissolved organic matter concentrations and bioavailability in an Appalachian stream, Biogeochemistry, 53, 269-306.

. $\mathrm{X}$

Bullen, W.H. (1988) Fisheries management plan for the Salmon Trout River. Marquette County, Michigan: Michigan Department of Natural Resources Fisheries Division. Technical Report 88 (7).

Butman, D., and Raymond, P.A. (2011) Significant efflux of carbon dioxide from streams and rivers in the United States. Nat. Geosci., 4, 829-842.

Coble, A.A., Marcarelli, A.M., and Kane, E.S. (in review) Nutrient limitation of dissolved organic carbon mineralization in a Lake Superior tributary, J.Great Lakes Res.

Cryer, J.D., and Chan, K.S. (2008) Time series analysis with applications in R. $2^{\text {nd }}$ edition. Springer, New York.

Fellman, J.B., Spencer, R.G.M., Hernes, P.J., Edwards, R.T., D’Amore, D.V., Hood, E. (2010) The impact of glacier runoff on the biodegradability and biochemical composition of terrigenous dissolved organic matter in near-shore marine ecosystems. Mar. Chem. 121, 112-122, doi: 10.1016/j.marchem.2010.03.009.

Fellman, J.B., Hood, E., D’Amore, D.V., Edwards, R.T., White, D. (2009a) Seasonal changes in the chemical quality and biodegradability of dissolved organic matter exported from soils to streams in coastal temperate rainforest watersheds. Biogeochemistry, 95, 277-293. doi:10.1007/s10533-009-9336-6. 
Fellman, J.B., Hood, E., Edwards, R.T., and D'Amore, D.V.D. (2009b) Changes in the concentration, biodegradability, and fluorescent properties of dissolved organic matter during stormflows in coastal temperate watershed. J.Geophys.. Res. 114, G01021, doi: 10.1029/2008JG000790.

Finlay, J., Neff, J., Zimov, S., Davydova, A., and Davydov, S. (2006) Snowmelt dominance of dissolved organic carbon in high-latitude watersheds: implications for characterization and flux of river DOC. Geophys. Res. Lett., 33, L10401, doi:10.1029/2006GL025754.

Frazier, S. W., Kaplan, L. A., and Hatcher, P. G. (2005) Molecular characterization of biodegradable dissolved organic matter using bioreactors and [12C/13C] tetramethylammonium hydroxide thermochemolysis GC-MS. Environ. Sci.Technol., 39(6), 1479-1491.

Frost, P. C., et al. (2006) Landscape predictors of stream dissolved organic matter concentration and physicochemistry in a Lake Superior river watershed, Aquat. Sci., $68,40-51$.

Gergel, S. E., Turner, M. G., and Kratz, T. K. (1999) Dissolved organic carbon as an indicator of the scale of watershed influence on lakes and rivers, Ecol. Appl., 9(4), $1377-1390$.

Gordon, N.D., McMahon, T. A., Finlayson, B.L., Gippel, C. J., and Nathan, R. J. (2004) Stream hydrology: an introduction for ecologists. John Wiley \& Sons Ltd.: West Sussex, $448 \mathrm{pp}$. 
Groisman, P.Y., Knight, R.W., Karl, T.R., Easterline, D.R., Sun, B., and Lawrimore, J.H. (2004) Contemporary changes of the hydrological cycle over the contiguous United States: trends derived from in situ observations. J. Hydrometeor., 5: 64-85.

Hall, R. O. Jr, and Meyer, J. L. (1998) The trophic significance of bacteria in a detritusbased stream food web. Ecology, 79(6), 1995-2012.

Henry, H.A.L. (2008) Climate change and soil freezing dynamics: historical trends and projected changes. Clim. Chang., 87, 421-434.

Holmes, R.M., Aminot, A., Kerouel, R., Hooker, B.A., and Peterson, B.J. (1999) A simple and precise method for measuring ammonium in marine and freshwater ecosystems. Can.J. Fish. Aquat. Sci., 56, 1801-1808.

Holmes, R. M., McClelland, J.W., Raymond, P.A., Frazer, B.B., Peterson, B.J., and Stieglitz, M. (2008) Lability of DOC transported by Alaskan rivers to the Arctic Ocean. Geophys. Res. Lett. 35, L03402, doi:10.1029/2007GL032837.

Hyndman, R. J. (2015) forecast: forecasting functions for time series and linear models. R package Version 5.8. Available at http:cran.rproject.org/web/packages/forecast/index.html

Jaffe, R., McKnight, D., Maie, N., Cory, R., McDowell, W.H., and Campbell, J.L. (2008) Spatial and temporal variations in DOM composition in ecosystems: the importance of long-term monitoring of optical properties. J. Geophys. Res., 113, G04032, doi:10.1029/2008JG000683.

Judd, K. E., Likens, G.E., Buso, D.C., and Bailey, A.S. (2011) Minimal response in watershed nitrate export to severe soil frost raises questions about nutrient dynamics 
in the Hubbard Brook experimental forest. Biogeochemistry 106, 443-459, doi 10.1007/s10533-010-9524-4.

Kaplan, L.A., and Bott, T.L. (1982) Diel fluctuations of DOC generated by algae in a piedmont stream. Limnol. Oceangr. 27, 1091-1100.

Kaplan, L.A. , and Newbold, J.D. (1995) Measurement of streamwater biodegradable dissolved organic carbon with a plug-flow bioreactor. Wat. Res., 29(12), 2696-2706.

Kendall, K.A., Shanley, J.B., and McDonnell, J.J. (1999) A hydrometric and geochemical approach to test the transmissivity feedback hypothesis during snowmelt. J. Hydrol. 219, 188-205.

Larson, J.H., Frost, P.C., Lodge, D.M., and Lamberti, G.A. (2007) Photodegradation of dissolved organic matter in forested streams of the northern Great Lakes region. $J . N$. Am Benthol Soc, 26(3), 416-425.

Laudon, H., Köhler, S., and Buffam, I. (2004) Seasonal TOC export from seven boreal catchments in northern Sweden. Aquat. Sci., 66(2), 223-230.

Mann, P.J., et al. (2012) Controls on the composition and lability of dissolved organic matter in Siberia's Kolyma River basin. J. Geophys. Res., 117, G01028, doi:10.1029/2011JG001798

Maranger, R., and Pullen, M.J. (2003) Elemental complexation by dissolved organic matter in lakes: implications for Fe speciation and the bioavailability of Fe and P. In: Aquatic ecosytems interactivity of dissolved organic matter. Editors: Findlay S.E., and Sinsabaugh R.L. Academic Press, San Diego

Marschner, B., and Kalbitz, K. (2003) Controls of bioavailability and biodegradability of dissolved organic matter in soils. Geoderma 113, 211-235. 
McGuire, K. J., J. J. McDonnell, M. Weiler, C. Kendall, B. L. McGlynn, J. M. Welker, and J. Seibert. 2005. The role of topography on catchment-scale water residence time. Water Resour. Res., 41, W05002, doi: 10.1029/2004WR003657.

McKnight, D.M., Boyer, E.W., Westerhoff, P.K., Doran, P.T., Kulbe, T., and Anderson, D.T. (2001) Spectrofluorometric characterization of dissolved organic matter for indication of precursor organic material and aromaticity. Limnol. Oceanogr., 46, 3848, doi:10.4319/1o.2001.46.1.0038.

Meybeck, M. (1982) Carbon, nitrogen, and phosphorus transport by World Rivers. American J.Sci. 282, 401-450.

Minor, R., and Stephens, B. (2008) Dissolved organic matter characteristics within the Lake Superior watershed. Org. Geochem., 39, 1489-1501.

Moran, M.A., and Hodson, R.E. (1990) Bacterial production on humic and nonhumic components of dissolved organic carbon. Limnol. Oceanogr., 35(8), 1744-1756.

Mortsch, L.D., and Quinn, F.H. (1996) Climate change scenarios for Great Lakes Basin ecosystem studies. Limnol. Oceanogr., 41(5), 903-911.

Olefeldt, D., Teretsky, M.R., and Blodau, C. (2013) Altered composition and microbial versus UV-mediated degradation of dissolved organic matter in boreal soils following wildfire. Ecosystems, 16, 1396-1412.

Plummer, L.N. and Busenberg, E. (1982) The solubilities of calcite, aragonite and vaterite in $\mathrm{CO}_{2}-\mathrm{H}_{2} \mathrm{O}$ solutions between 0 and $90^{\circ} \mathrm{C}$, and an evaluation of the aqueous model for the system $\mathrm{CaCO}_{3}-\mathrm{CO}_{2}-\mathrm{H}_{2} \mathrm{O}$. Geochim. Cosmochim. Ac., 46, 1011-1040, doi:10.1016/0016-7037(82)90056-4. 
Raymond, P. A., and Saiers, J. E. (2010) Event controlled DOC export from forested watersheds. Biogeochemistry, 100, 197-209, doi: 10.1007/s10533-010-9416-7.

Runkel, R. L., Crawford, C. G., and Cohn, T. A. (2004) Load Estimator (LOADEST): A FORTRAN program for estimating constituent loads in streams and rivers. US Department of the Interior, US Geological Survey.

Schindler, D.W., Curtis, P.J., Bayley, S.E., Parker, B.R., Beaty, K.G., and Stainton, M.P. (1997) Climate-induced changes in the dissolved organic carbon budgets of boreal lakes. Biogeochemistry, 36, 9-28.

Schmitt, A., Glaser, B., Borken, W., and Matzner, E. (2008) Repeated freeze-thaw cycles changed organic matter quality in a temperate forest soil. J. Plant Nutr. Soil Sc., 171, 707-718, doi: 10.1002/jpln.200700334.

Semkin, R.G., Hazlett, P.W., Beall, F.D., and Jeffries, D.S. (2002) Development of stream water chemistry during spring melt in a northern hardwood forest. Water Air Soil Poll, 2, 37-61.

Singh, S., Inamdar, I., and Mitchell, M. (2014) Changes in dissolved organic matter (DOM) amount and composition along nested headwater stream locations during baseflow and stormflow. Hydrol. Process., doi: 10.1002/hyp/10286.

Stedmon, C.A., Markager, S., and Bro, R. (2003) Tracing dissolved organic matter in aquatic environments using a new approach to fluorescence spectroscopy. Mar. Chem., 82, 239-254, doi:10.1016/S0304-4203(03)00072-0.

Stedmon, C.A., and Bro, R. (2008) Characterizing dissolved organic matter fluorescence with parallel factor analysis: a tutorial. Limnol. Oceanogr., 6, 572-579, doi:10.4319/lom.2008.6.572. 
Stedmon, C.A., and Markager, S. (2005a) Resolving the variability in dissolved organic matter fluorescence in a temperate estuary and its catchment using PARAFAC analysis. Limnol. Oceanogr, 50, 686-697.

Stedmon, C. A., and Markager, S. (2005b). Tracing the production and degradation of autochthonous fractions of dissolved organic matter by fluorescence analysis. Limnol. Oceanogr, 50,1415-1426

Stottlemyer, R (1987) Snowpack ion accumulation and loss in a Lake Superior Basin watershed. Can.J. Fish. Aquat. Sci., 44, 1812-1819

Stottlemyer, R., and Rutkowski, D. (1990) Multi-year trends in snowpack ion accumulation and loss, Northern Michigan. Water Resour. Res. 26, 721-737.

Stottlemyer, R., and Toczydlowski, D. (2006) Effect of reduced winter precipitation and increased temperature on watershed solute flux, Biogeochemistry, 77, 409-440, doi 10.1007/s10533-005-1810-1.

Striegl, R.G., Aiken, G.R., Dornblaser, M.M., Raymond, P.A., Wickland, K.P. (2005) A decrease in discharge-normalized DOC export by the Yukon River during summer through autumn. Geophys. Res. Lett., 32, L21413.

Striegl, R.G., Kortelainen, P., Chanton, J.P., Wickland, K.P., Bugna, G.C., and Rantakari, M. (2001) Carbon dioxide partial pressure and 13C content of north temperate and boreal lakes at spring ice melt. Limnol.Oceanogr., 46, 941-945, doi:10.4319/1o/2001.46.4.0941.

Taylor, B.W., Keep, C.F., Hall, R.O., Koch, B.J., Tronstad, L.M., Flecker, A.S., and Ulseth, A.J. (2007) Improving the fluorometric ammonium method: matrix effects, 
background fluorescence, and standard additions. J. N. Am. Benthol.Soc., 26(2), 167177.

Thompson, M. E. (1978), Major ion loadings to Lake Superior, J. Great Lakes Res., 4(34), 361-369, doi:10.1016/S0380-1330(78)72206-9.

Uchida, T., J. J. McDonnell, and Y. Asano (2006) Functional intercomparison of hillslopes and small catchments by examining water source, flowpath and mean residence time. J. Hydrol., 327, 627-642.

Urban, N. R., M. T. Auer, S. A. Green, X. Lu, D. S. Apul, K. D. Powell, and L. Bub (2005), Carbon cycling in Lake Superior, J. Geophys. Res., 110, C06S90, doi:10.1029/2003JC002230.

Volk, C.J., Volk, C.B., and Kaplan, L.A. (1997) Chemical composition of biodegradable dissolved organic matter in streamwater. Limnol. Oceanogr. 42, 39-44

Weishaar, J.L., Aiken, G.R., Bergamaschi, B.A., Fram, M.S., and Fujii, R. (2003) Evaluation of specific ultraviolet absorbance as an indicator of the chemical composition and reactivity of dissolved organic carbon. Environ. Sci.Technol. 37, 4702-4708, doi:10.1021/es030360x.

Wickland, K. P., et al. (2012), Biodegradability of dissolved organic carbon in the Yukon River and its tributaries: seasonality and importance of inorganic nitrogen, Global Biogeochem. Cycles 26, GBOE03, doi:10.1029/2012GB004342.

Wilson, H. F., and Xenopoulos, M.A. (2008) Effects of agricultural land use on the composition of fluvial dissolved organic matter. Nat. Geosci., 2, 37-41, doi: 10.1038/ngeo391. 
Wise, B. M., Shaver, J.M., Gallagher, N.B., Windig, W., Bro, R., and Koch, R.S. Manual PLS_Toolbox, Version 4.0., Eigenvector Research Inc, Wenatchee, USA, 2006

Wuebbles, D.J., and Hayhoe, K. (2004) Climate change projections for the United States Midwest. Mitig. Adapt. Strategies Glob. Chang., 9, 335-363.

Yamashita, Y., Kloeppel, B. D., Knoepp, J., Zausen, G.L., and Jaffe', R. (2011) Effects of watershed history on dissolved organic matter characteristics in headwater streams. Ecosystems 14, 110-1122, doi: 10.1007/s10021-011-9469-z.

Yamashita, Y., Tanoue, E. (2003) Chemical characterization of protein-like fluorophores in DOM in relation to aromatic acids. Mar. Chem. 82, 255-271.

Yamashita, Y., Tanoue, E. (2004) Chemical characteristics of amino acid-containing dissolved organic matter in seawater. Org. Geochem., 35, 679-692.

Zuur, A.F., Leno, E.N., Walker, J.J., Saveliev, A.A., and Smith, G.M. (2009) Mixed effects models and extensions in ecology with R. Springer, New York. 


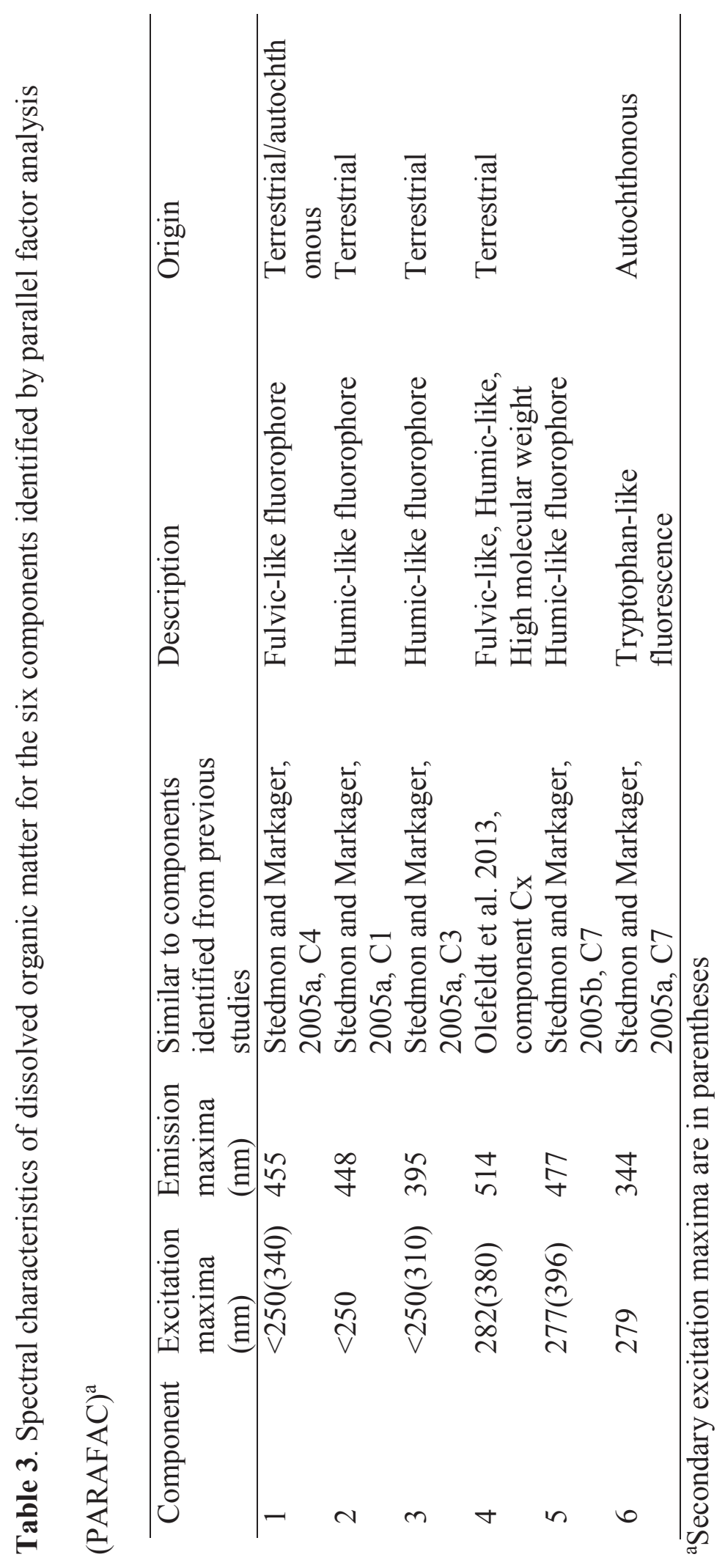


Table 4: Partial least squares model performance as a function of the number of latent variables.

\begin{tabular}{llrl}
\hline $\begin{array}{l}\text { Latent } \\
\text { Variable }\end{array}$ & $\begin{array}{l}\text { X } \\
\text { cumulative } \\
\text { variance } \\
\text { explained } \\
(\%)\end{array}$ & $\begin{array}{l}\text { Y } \\
\text { cumulative } \\
\text { variance } \\
\text { explained } \\
(\%)\end{array}$ & RMSECV \\
\hline 1 & 64.01 & 5.92 & 14.22 \\
2 & 78.53 & 13.22 & 14.83 \\
3 & 84.69 & 15.25 & 15.45 \\
4 & 94.20 & 16.95 & 15.39 \\
\hline
\end{tabular}


Table 5. Linear regressions of biodegradable dissolved organic carbon (BDOC) versus DOM characteristics $^{\mathrm{a}}$

\begin{tabular}{llrcr}
\hline Variable & Equation & $\mathrm{r}^{2}$ & $\mathrm{~F}$ & $\mathrm{p}$ \\
\hline $\mathrm{C} 1$ & $\mathrm{~ns}$ & 0.02 & 1.52 & 0.22 \\
$\mathrm{C} 2$ & $\mathrm{~ns}$ & 0.01 & 0.41 & 0.52 \\
$\mathrm{C} 3$ & $\mathrm{~ns}$ & 0.00 & 0.03 & 0.86 \\
$\mathrm{C} 4$ & $\mathrm{~ns}$ & 0.00 & 0.21 & 0.65 \\
$\mathrm{C} 5$ & $\mathrm{~ns}$ & 0.01 & 0.46 & 0.50 \\
$\mathrm{C} 6$ & $\mathrm{~ns}$ & 0.02 & 1.62 & 0.21 \\
DOC & $\mathrm{ns}$ & 0.01 & 0.52 & 0.47 \\
SUVA & $\mathrm{ns}$ & 0.01 & 0.44 & 0.51 \\
FI & $\mathrm{ns}$ & 0.00 & 0.00 & 0.95 \\
DOC:DIN & $\mathrm{ns}$ & 0.02 & 0.63 & 0.43 \\
${ }_{\text {nns indicates }}$ linear regression was not significant at $\mathrm{p}<0.05$
\end{tabular}


Table 6: Watershed area $\left(\mathrm{km}^{2}\right)$, annual DOC $\left(\mathrm{kg} \mathrm{yr}^{-1}\right)$ and annual BDOC loads $\left(\mathrm{kg} \mathrm{yr}^{-1}\right)$ for each river for the period of sampling (July 1 2013-June 30 2014).

\begin{tabular}{lrrr}
\hline River & $\begin{array}{l}\text { Watershed } \\
\text { Area }\left(\mathrm{km}^{2}\right)\end{array}$ & $\begin{array}{l}\text { DOC load } \\
\left(\mathrm{kg} \mathrm{yr}^{-1}\right)\end{array}$ & \multicolumn{2}{l}{$\begin{array}{l}\text { BDOC load } \\
\left(\mathrm{kg} \mathrm{yr}^{-1}\right)\end{array}$} \\
\hline Calumet Watershed & $1.76^{\mathrm{a}}$ & 4,899 & 422 \\
Salmon Trout River & $127^{\mathrm{b}}$ & 310,100 & 52,440 \\
Ontonagon River & $3,470^{\mathrm{c}}$ & $17,810,000$ & $2,788,000$ \\
\hline
\end{tabular}

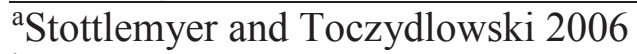

${ }^{b}$ Bullen 1988

${ }^{\mathrm{c}}$ Thompson 1978 
Table 7: Structure of the autoregressive integrated moving average (ARIMA) model for monthly DOC and BDOC (1988-2014) loads exported from Calumet watershed ${ }^{\mathrm{a}}$.

\begin{tabular}{lllll}
\hline Response & \multicolumn{2}{l}{ Model structure } & \multicolumn{3}{l}{ Coefficients } \\
\hline \multirow{2}{*}{ DOC } & $(0,0,0)(1,0,1)[12]$ & 1.00 & -0.97 & 323.21 \\
& & $(0.00)$ & $(0.05)$ & $(106.43)$ \\
BDOC & $(0,0,0)(1,0,1)[12]$ & 1.00 & 0.99 & 29.91 \\
& & $(0.00)$ & $(0.01)$ & $(10.49)$
\end{tabular}

a SAR is the seasonal autoregressive coefficient, SMA is the seasonal moving average coefficient 
Table 8: Structure of the autoregressive integrated moving average (ARIMA) model for mean seasonal DOC (1988-2014) loads exported from Calumet watershed ${ }^{\mathrm{a}}$.

\begin{tabular}{llll}
\hline Season & & ma & drift \\
Spring & $(0,1,1)$ & $-1.00(0.12)$ & $7.32(7.02)$ \\
Summer & $(0,1,1)$ & $-1.00(0.16)$ & $1.71(3.11)$ \\
Fall & $(0,1,1)$ & $-1.00(0.13)$ & $-2.02(3.25)$ \\
Winter & $(0,1,1)$ & $-1.00(0.16)$ & $0.89(1.06)$ \\
\hline
\end{tabular}

${ }^{\mathrm{a}} \mathrm{MA}$ is the moving average coefficient 


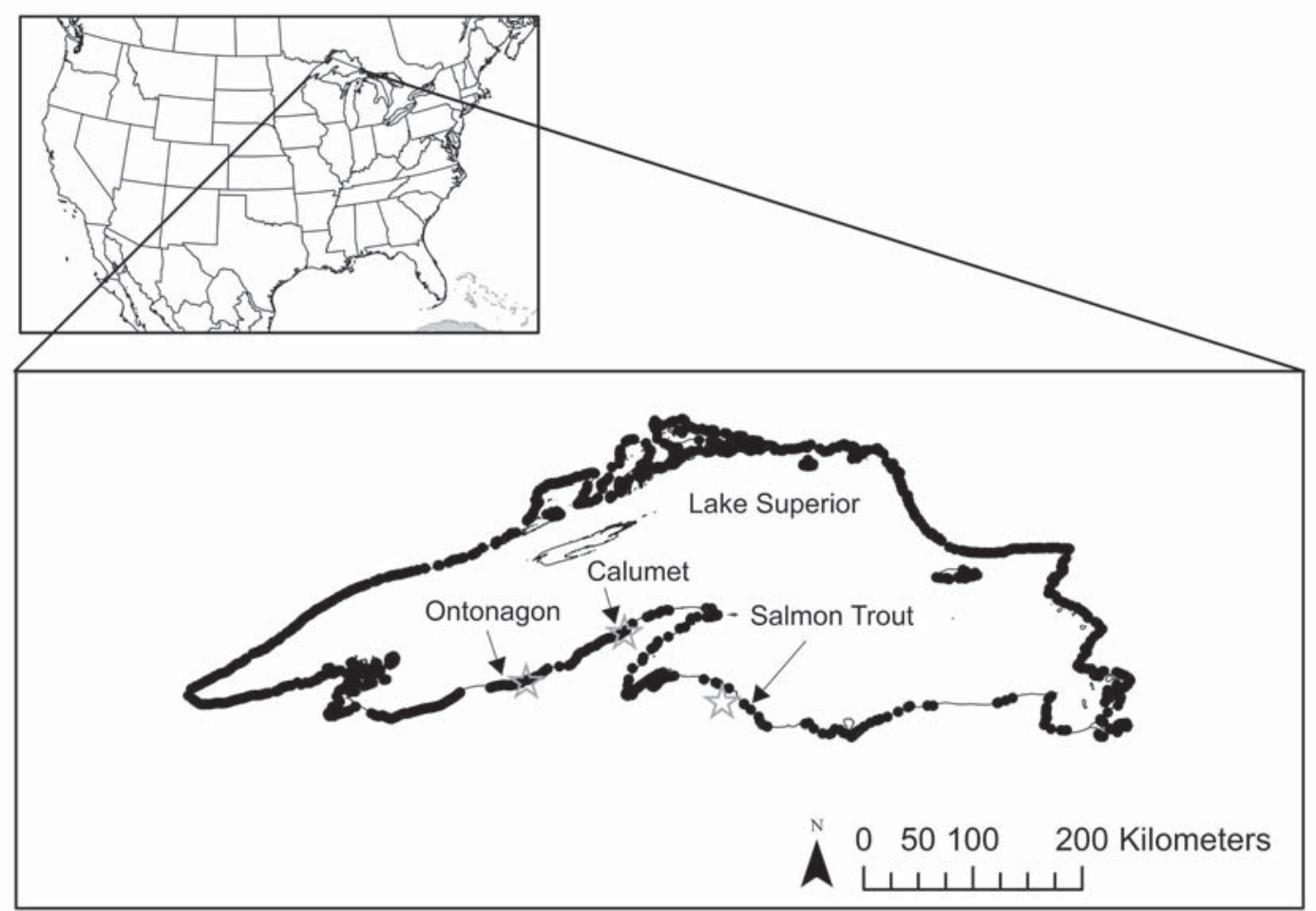

Figure 3. Map of the tributaries of Lake Superior with the location of the three study sites indicated. Tributaries for the United States identified from National Hydrography Dataset and tributaries for Canada identified from Ontario Hydro Network. 


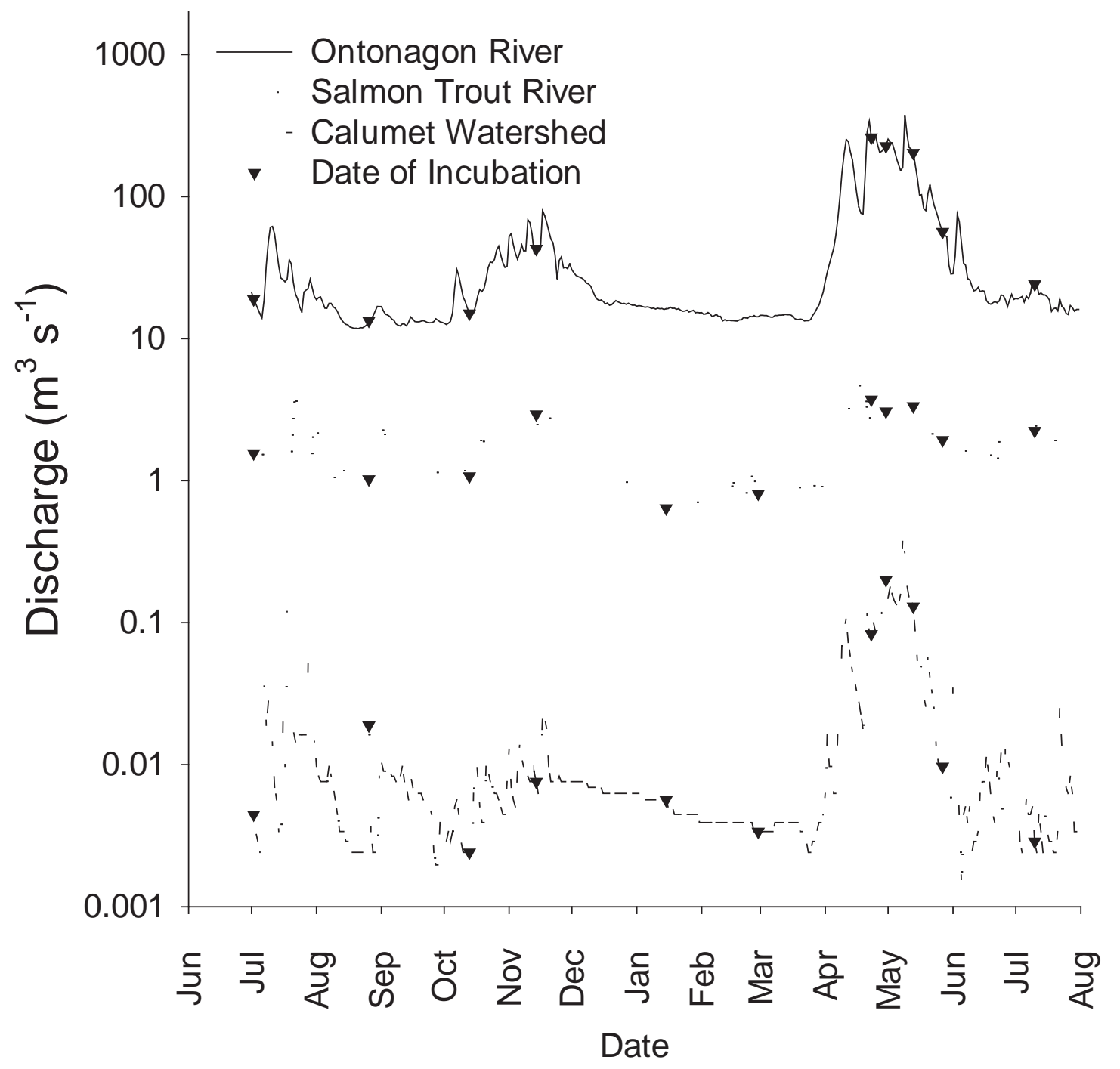

Figure 4. Annual discharge from July 1, 2013- July 31, 2014 for Calumet Watershed, Salmon Trout River, and Ontonagon River. Downward triangles indicate sampling dates. 


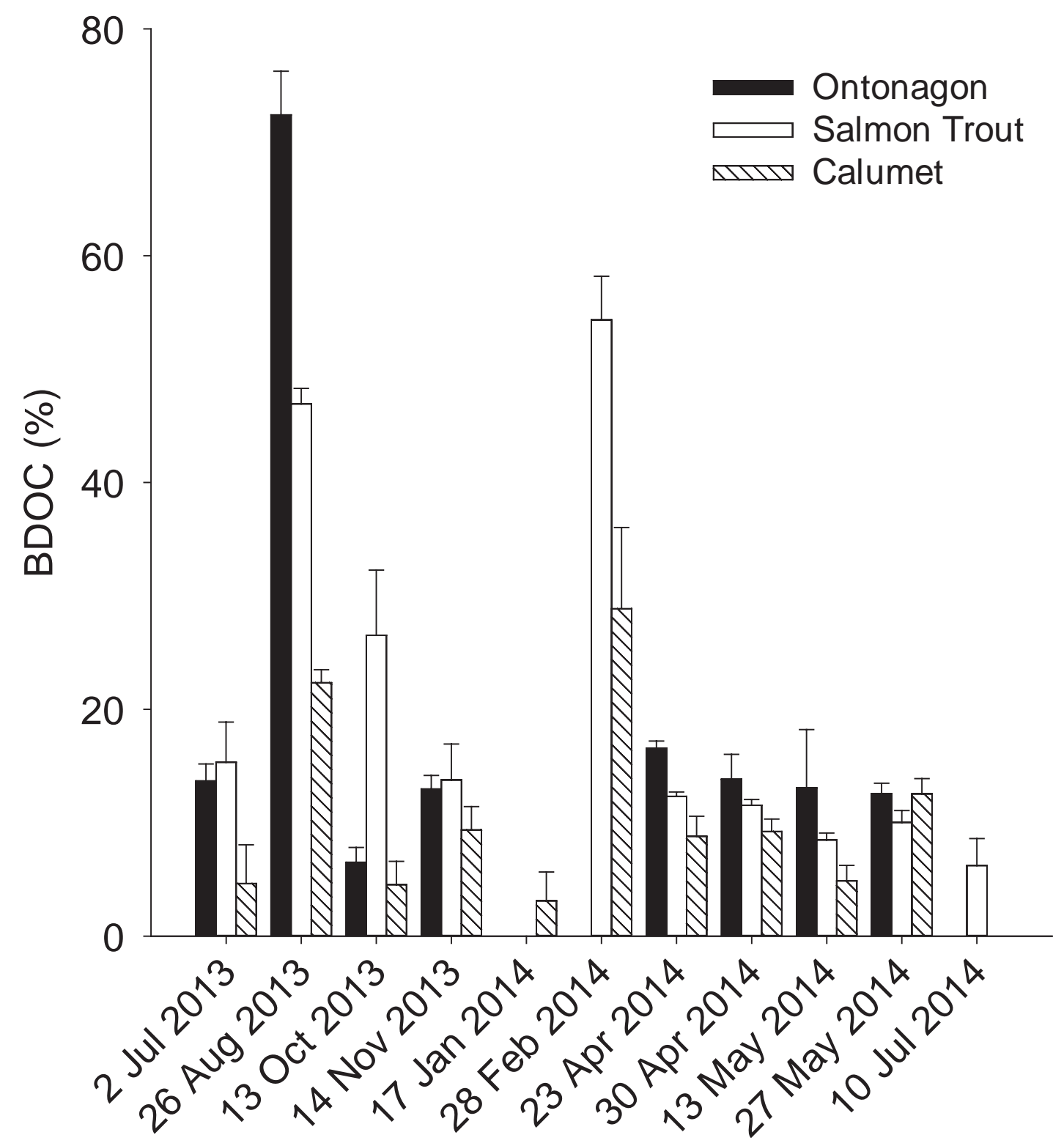

Figure 5. Percent of biodegradable dissolved organic carbon (BDOC) measured in each of three rivers: Calumet Watershed, Salmon Trout River, and Ontonagon River on sampling dates in 2013-2014. Error bars represent standard error. Values below zero were replaced with a zero value, although BDOC values were not altered for statistical analysis. 

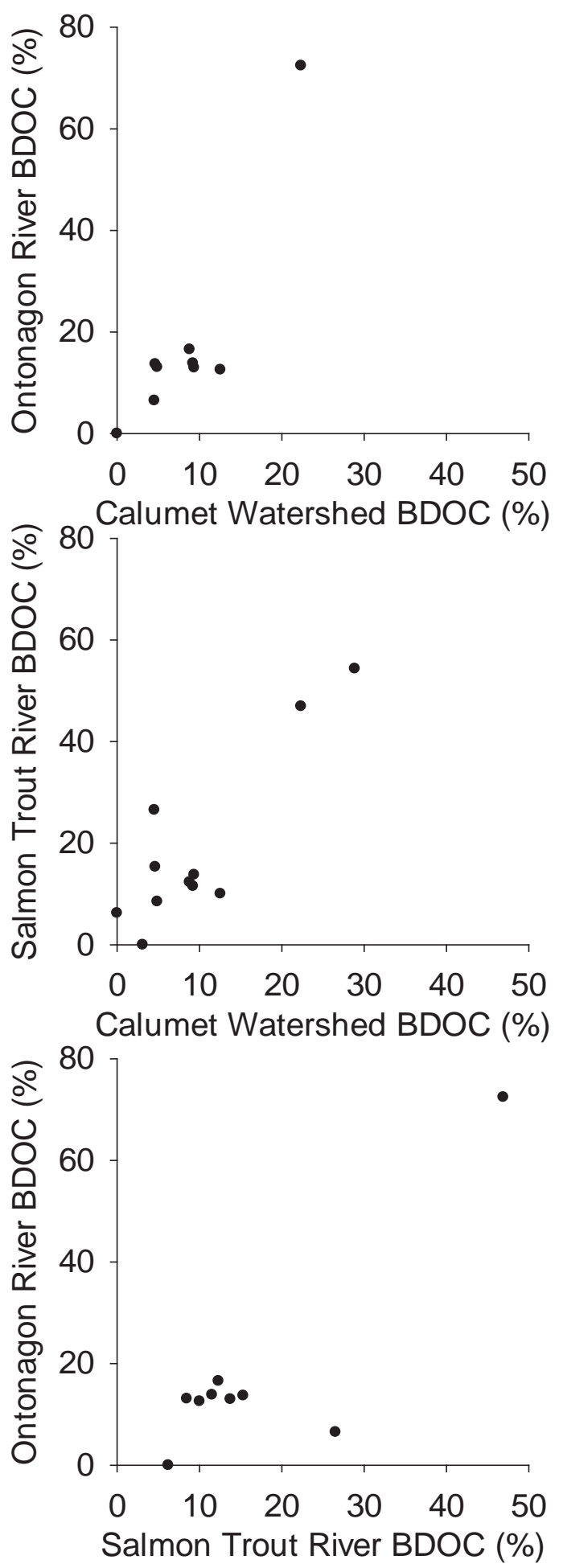

Figure 6. Correlation of BDOC among sites with regression line displayed. 


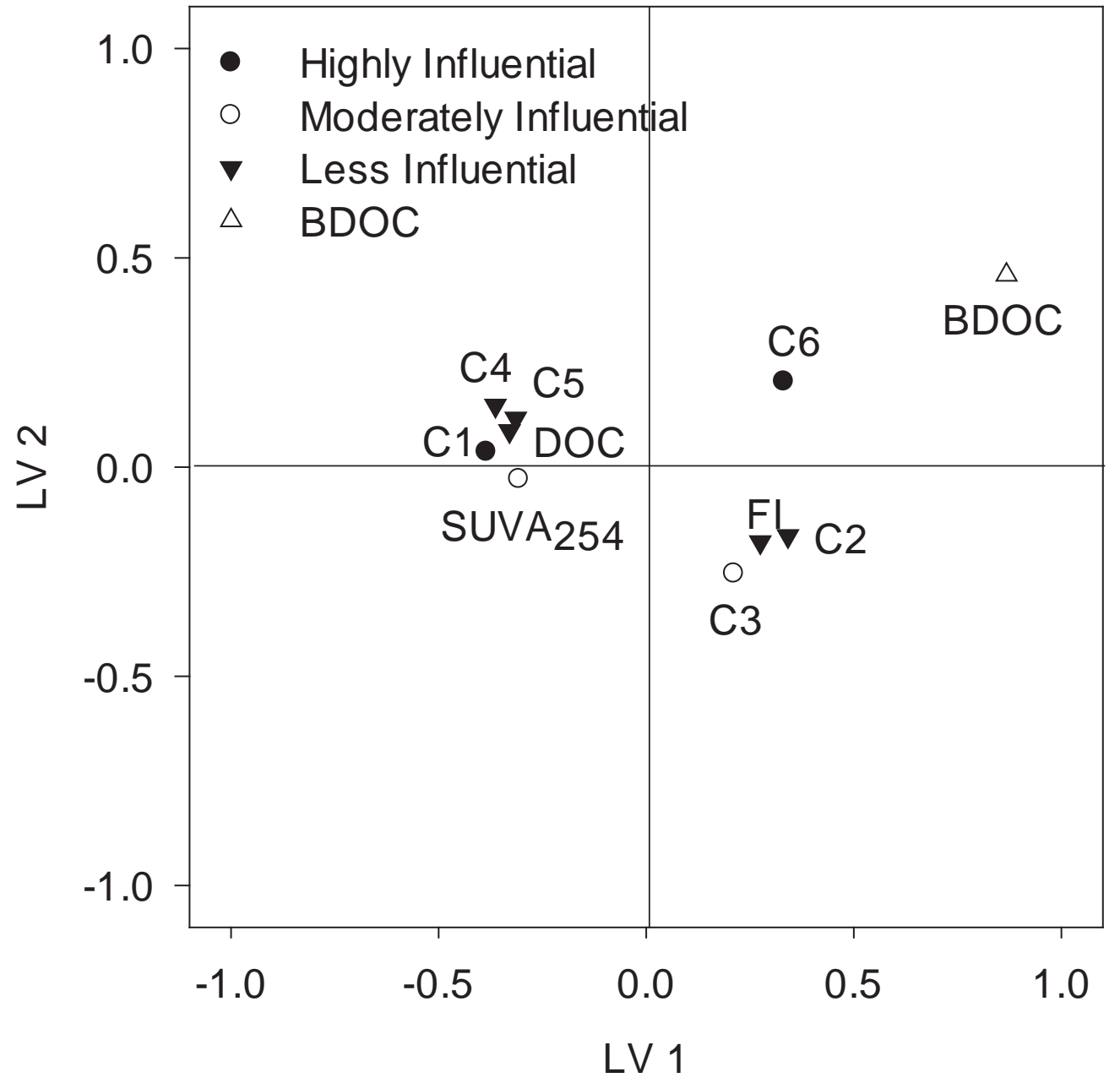

Figure 7. Property-property plots for the first and third latent variable loadings from the partial least squares (PLS) analysis for DOC concentration and DOM characteristics (X variables) and BDOC (Y variable). 


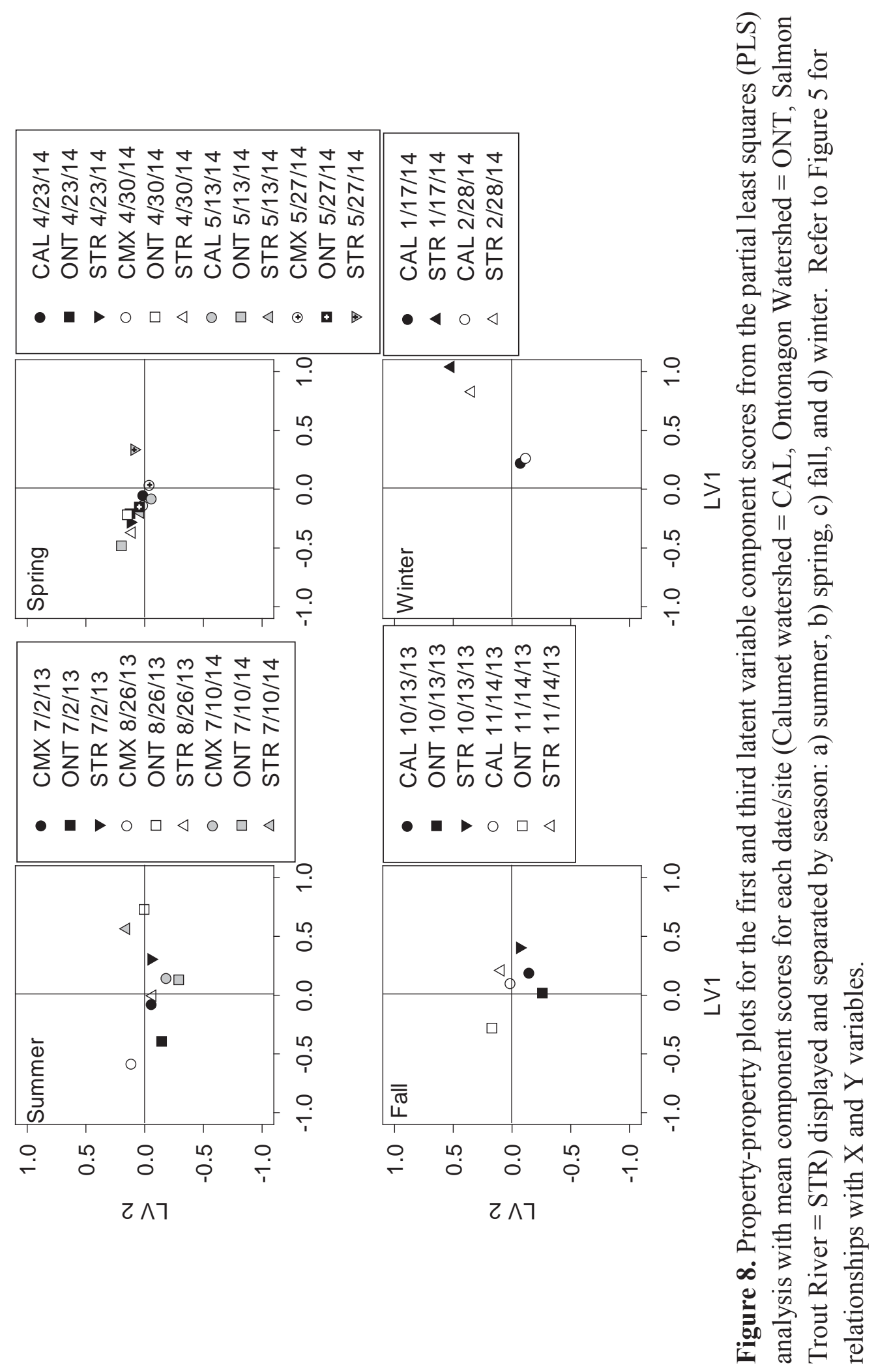



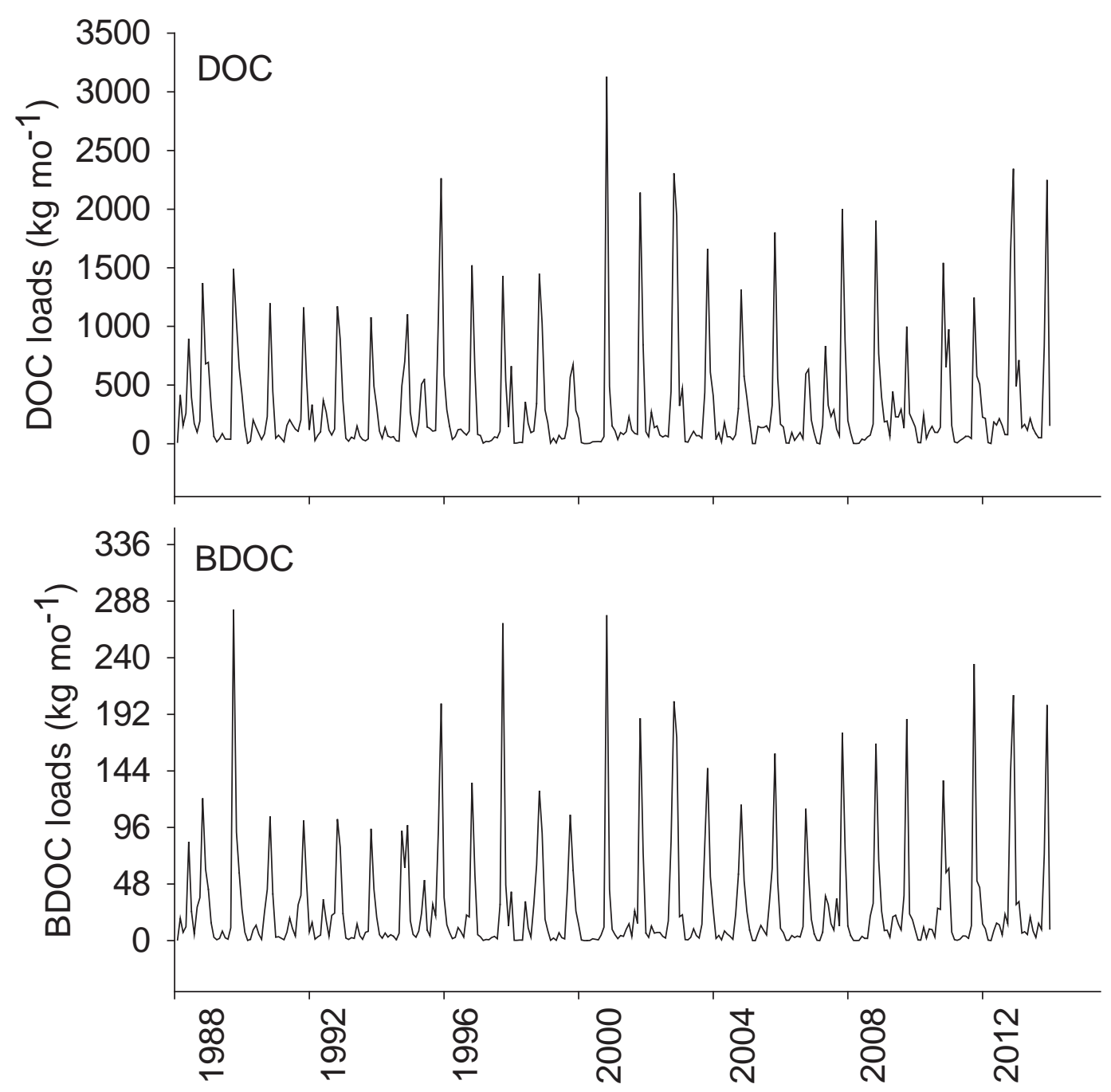

Figure 9. Time series of monthly loads for the Calumet Watershed from July 1988 through June 2014 for: a.) dissolved organic carbon (DOC) and b) BDOC. 


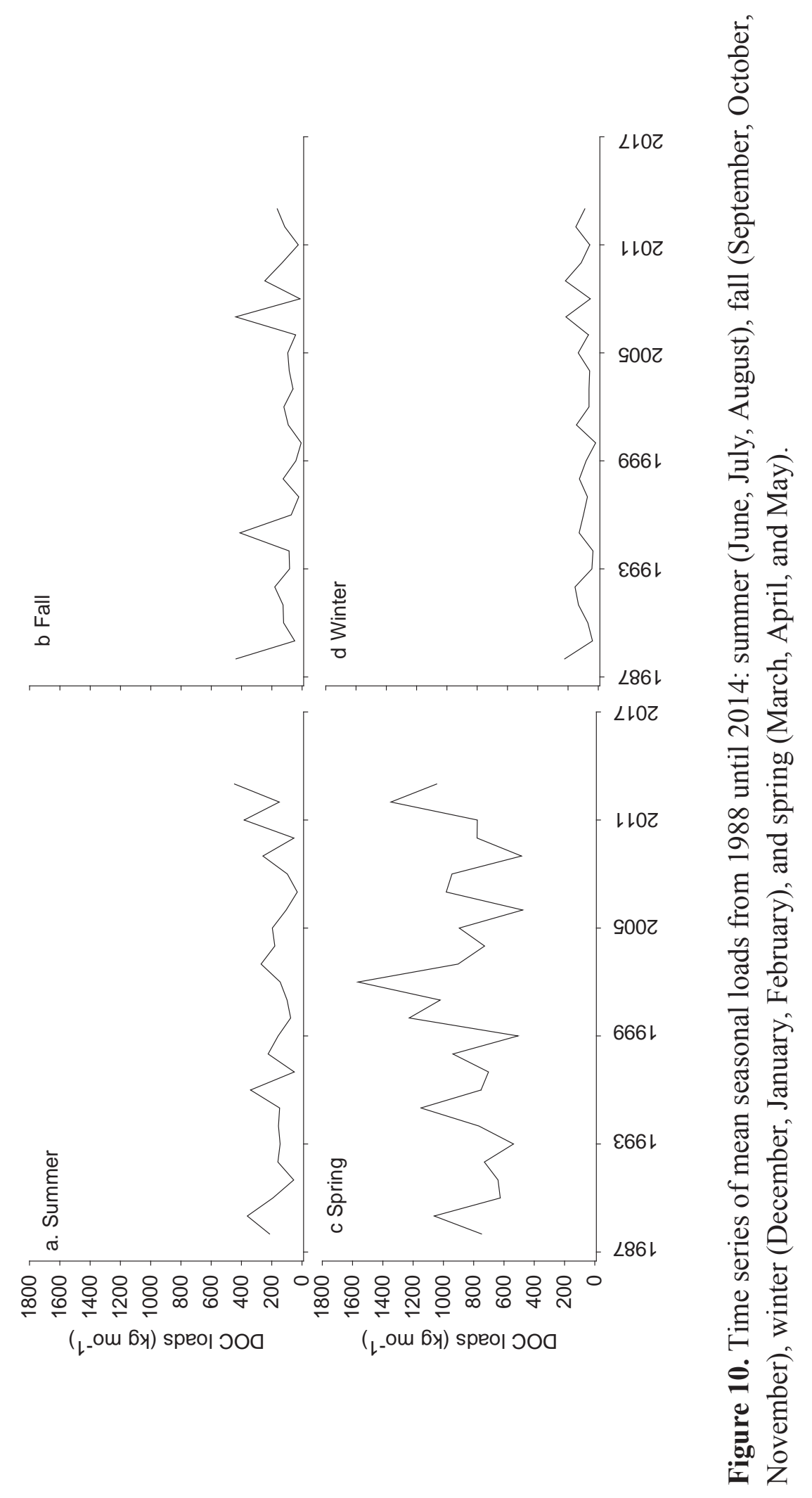




\section{Appendix}

Appendix Table 1. Initial Stream Conditions on Dates of Stream Water Collection for Incubation Experiments ${ }^{\mathrm{a}}$

\begin{tabular}{|c|c|c|c|c|c|c|}
\hline Site & Date & $\begin{array}{l}\text { Discharge } \\
\left(\mathrm{m}^{3} \mathrm{sec}^{-1}\right)\end{array}$ & $\begin{array}{l}\text { Temperature } \\
\left({ }^{\circ} \mathrm{C}\right)\end{array}$ & $\begin{array}{l}\text { Conductivity } \\
\left(\mathrm{mS} \mathrm{cm}^{-1}\right)\end{array}$ & $\mathrm{pH}$ & $\begin{array}{l}\mathrm{DO} \\
(\%) \\
\end{array}$ \\
\hline \multirow[t]{11}{*}{ Calumet } & $07 / 02 / 13$ & 0.005 & 12.15 & 0.109 & 8.35 & 95.6 \\
\hline & $08 / 26 / 13$ & 0.019 & 18.32 & 0.121 & 7.81 & 95.9 \\
\hline & $10 / 13 / 13$ & 0.002 & 10.87 & 0.164 & 8.00 & 96.2 \\
\hline & $11 / 14 / 13$ & 0.008 & 3.72 & 0.132 & 7.89 & 94.2 \\
\hline & $01 / 15 / 14$ & 0.006 & 0.12 & 0.134 & 8.37 & 88.1 \\
\hline & $02 / 28 / 14$ & 0.004 & -0.22 & 0.08 & 8.80 & 95.3 \\
\hline & $04 / 23 / 14$ & 0.084 & 1.33 & 0.07 & 8.47 & 99.2 \\
\hline & $04 / 30 / 14$ & 0.201 & 0.97 & 0.06 & 8.51 & 97.6 \\
\hline & $05 / 13 / 14$ & 0.131 & 4.48 & 0.06 & 8.58 & 75.5 \\
\hline & $05 / 27 / 14$ & 0.010 & 12.40 & 0.09 & 8.03 & 96.1 \\
\hline & $07 / 10 / 14$ & 0.003 & 12.54 & 0.135 & 8.02 & 97.2 \\
\hline \multirow[t]{11}{*}{ Salmon Trout } & $07 / 02 / 13$ & 1.571 & 13.61 & 0.148 & 7.46 & 95.1 \\
\hline & $08 / 26 / 13$ & 1.029 & 19.65 & 0.105 & 8.14 & 95.2 \\
\hline & $10 / 13 / 13$ & 1.081 & 11.57 & 0.141 & 7.77 & 98.8 \\
\hline & $11 / 14 / 13$ & 2.950 & 2.28 & 0.124 & 7.81 & 93.3 \\
\hline & $01 / 15 / 14$ & 0.644 & 0.35 & 0.149 & 8.06 & 95.2 \\
\hline & $02 / 28 / 14$ & 0.817 & 0.06 & 0.160 & 8.41 & NA \\
\hline & $04 / 23 / 14$ & 3.751 & 1.12 & 0.060 & 7.93 & 97.8 \\
\hline & $04 / 30 / 14$ & 3.093 & 1.44 & 0.054 & 7.74 & 99.5 \\
\hline & $05 / 13 / 14$ & 3.364 & 8.18 & 0.076 & 8.69 & 96.5 \\
\hline & $05 / 27 / 14$ & 1.947 & 15.08 & 0.118 & 8.46 & 97.5 \\
\hline & $07 / 10 / 14$ & 2.259 & 16.94 & 0.135 & 7.80 & 97.2 \\
\hline \multirow[t]{7}{*}{ Ontonagon } & $07 / 02 / 13$ & 21.188 & 23.38 & 0.152 & 8.36 & 91.2 \\
\hline & $08 / 26 / 13$ & 13.473 & 23.85 & 0.189 & 8.13 & 89.5 \\
\hline & $10 / 13 / 13$ & 15.148 & 12.81 & 0.159 & 7.83 & 92.0 \\
\hline & $11 / 14 / 13$ & 43.400 & 1.28 & 0.115 & 8.07 & 94.7 \\
\hline & $04 / 23 / 14$ & 263.056 & 0.73 & 0.067 & 8.2 & 98.5 \\
\hline & $04 / 30 / 14$ & 228.793 & 2.83 & 0.071 & 8.03 & 97.2 \\
\hline & $05 / 13 / 14$ & 205.291 & 9.74 & 0.094 & 8.79 & 95.8 \\
\hline
\end{tabular}




\section{Appendix Table 1. Continued}

\begin{tabular}{llrrrrl}
\hline Site & Date & $\begin{array}{l}\text { Discharge } \\
\left(\mathrm{m}^{3} \mathrm{sec}^{-1}\right)\end{array}$ & $\begin{array}{l}\text { Temperature } \\
\left({ }^{\circ} \mathrm{C}\right)\end{array}$ & $\begin{array}{l}\text { Conductivity } \\
\left(\mathrm{mS} \mathrm{cm}^{-1}\right)\end{array}$ & $\begin{array}{l}\mathrm{pO} \\
(\%)\end{array}$ \\
\hline Ontonagon & $05 / 27 / 14$ & 56.915 & 19.2 & 0.108 & 8.31 & 95.0 \\
& $07 / 10 / 14$ & 24.305 & 20.82 & 0.155 & 8.14 & 91.9 \\
\hline
\end{tabular}

${ }^{a}$ Temperature (Temp.), Conductivity, $\mathrm{pH}$, and Dissolved Oxygen (DO) were measured with YSI multiparameter sonde deployed in each river on the date of stream water collection. 
Appendix Table 2. Initial stream chemistry on dates of stream water collection for incubation experiments ${ }^{\mathrm{a}}$

\begin{tabular}{|c|c|c|c|c|c|c|c|c|c|}
\hline Site & Date & $\begin{array}{l}\mathrm{NH}_{4} \\
-\mathrm{N} \\
(\mu \mathrm{g} \\
\left.\mathrm{L}^{-1}\right)\end{array}$ & $\begin{array}{l}\mathrm{NO}_{3-} \\
\mathrm{N} \\
(\mathrm{mg} \\
\left.\mathrm{L}^{-1}\right)\end{array}$ & $\begin{array}{l}\text { SRP } \\
(\mu \mathrm{g} \\
\left.\mathrm{L}^{-1}\right)\end{array}$ & $\begin{array}{l}\text { Total } \\
\text { P }\end{array}$ & $\begin{array}{l}\text { DOC } \\
(\mathrm{mg} \\
\left.\mathrm{L}^{-1}\right)\end{array}$ & $\begin{array}{l}\text { TDN } \\
(\mathrm{mg} \\
\left.\mathrm{L}^{-1}\right)\end{array}$ & $\begin{array}{l}\text { SUVA } \\
254 \\
\left(\mathrm{~L} \mathrm{mg}^{-1}\right. \\
\left.\mathrm{m}^{-1}\right)\end{array}$ & FI \\
\hline \multirow[t]{11}{*}{ Calumet } & $7 / 02 / 13$ & 4.36 & 0.30 & bdl & 12.91 & 7.42 & 0.44 & 3.54 & 1.18 \\
\hline & $8 / 26 / 13$ & 2.16 & 0.16 & bdl & 30.40 & 18.96 & 0.78 & 3.33 & 1.17 \\
\hline & $10 / 13 / 13$ & 1.14 & bdl & bdl & 15.82 & 7.69 & 0.35 & 2.61 & 1.21 \\
\hline & $11 / 14 / 13$ & 3.20 & bdl & 3.20 & bdl & 8.97 & 0.43 & 2.88 & 1.20 \\
\hline & $1 / 15 / 14$ & 15.1 & 0.17 & bdl & bdl & 6.72 & 0.42 & 2.57 & 1.22 \\
\hline & $2 / 28 / 14$ & 22.0 & 0.15 & bdl & 15.82 & 5.63 & 0.42 & 2.94 & 1.22 \\
\hline & $4 / 23 / 14$ & bdl & 0.13 & bdl & 12.81 & 9.60 & 0.68 & 3.06 & 1.18 \\
\hline & $4 / 30 / 14$ & 2.66 & 0.11 & 3.20 & bdl & 9.43 & 0.51 & 3.45 & 1.16 \\
\hline & $5 / 13 / 14$ & bdl & bdl & bdl & 18.27 & 9.09 & 0.42 & 3.21 & 1.14 \\
\hline & $5 / 27 / 14$ & 0.20 & bdl & bdl & bdl & 8.76 & 0.41 & 2.85 & 1.18 \\
\hline & $7 / 10 / 14$ & bdl & bdl & bdl & 12.81 & 6.61 & 0.40 & 3.11 & 1.21 \\
\hline Salmon & $7 / 02 / 13$ & 17.5 & bdl & bdl & bdl & 4.45 & 0.37 & 3.45 & 1.17 \\
\hline \multirow[t]{10}{*}{ Trout } & $8 / 26 / 13$ & 1.15 & 0.17 & bdl & 15.82 & 9.54 & 0.58 & 3.38 & 1.17 \\
\hline & $10 / 13 / 13$ & 4.30 & bdl & bdl & bdl & 4.76 & 0.28 & 2.91 & 1.20 \\
\hline & $11 / 14 / 13$ & 3.66 & bdl & bdl & 12.91 & 6.56 & 0.36 & 3.09 & 1.19 \\
\hline & $1 / 15 / 14$ & bdl & 0.15 & bdl & 21.65 & 3.91 & 0.45 & 2.07 & 1.21 \\
\hline & $2 / 28 / 14$ & 7.51 & 0.14 & bdl & 21.65 & 2.73 & 0.3 & 2.61 & 1.20 \\
\hline & $4 / 23 / 14$ & 13.8 & 0.12 & bdl & bdl & 11.14 & 0.65 & 3.58 & 1.14 \\
\hline & $4 / 30 / 14$ & 2.26 & 0.10 & bdl & 15.54 & 10.71 & 0.5 & 2.83 & 1.14 \\
\hline & $5 / 13 / 14$ & bdl & bdl & bdl & 26.46 & 9.77 & 0.48 & 2.67 & 1.14 \\
\hline & $5 / 27 / 14$ & bdl & bdl & bdl & 16.54 & 6.98 & 0.43 & 2.97 & $1.1 \hat{4}$ \\
\hline & 7/10/14 & 4.16 & bdl & bdl & 18.27 & 4.90 & 0.47 & 3.49 & $1.1 \overline{8}$ \\
\hline \multirow[t]{7}{*}{ Ontonagon } & $7 / 02 / 13$ & 24.0 & 0.31 & 9.70 & 24.57 & 13.39 & 0.87 & 3.91 & 1.15 \\
\hline & $8 / 26 / 13$ & $2.0 \overline{4}$ & bdl & 3.20 & 18.74 & 7.85 & 0.42 & 2.53 & 1.17 \\
\hline & $10 / 13 / 13$ & 22.5 & bdl & 4.26 & 33.32 & 11.16 & 0.57 & 3.19 & 1.20 \\
\hline & $11 / 14 / 13$ & $40 . \hat{8}$ & 0.10 & 3.20 & 39.15 & 16.16 & 0.92 & 3.35 & 1.15 \\
\hline & $4 / 23 / 14$ & $19 . \hat{9}$ & 0.11 & 4.78 & 26.46 & 11.82 & 0.74 & 3.45 & 1.14 \\
\hline & $4 / 30 / 14$ & $9.4 \hat{5}$ & 0.11 & bdl & 26.46 & 11.43 & 0.75 & 3.76 & 1.13 \\
\hline & $5 / 13 / 14$ & 9.46 & bdl & 3.20 & 34.64 & 14.85 & 0.78 & 3.81 & 1.13 \\
\hline
\end{tabular}


$\overline{\text { Appendix Table } 2 \text {. Continued }}$

\begin{tabular}{|c|c|c|c|c|c|c|c|c|c|}
\hline Site & Date & $\begin{array}{l}\mathrm{NH}_{4} \\
-\mathrm{N} \\
(\mu \mathrm{g} \\
\left.\mathrm{L}^{-1}\right)\end{array}$ & $\begin{array}{l}\mathrm{NO}_{3-} \\
\mathrm{N} \\
(\mathrm{mg} \\
\left.\mathrm{L}^{-1}\right)\end{array}$ & $\begin{array}{l}\text { SRP } \\
(\mu g \\
\left.L^{-1}\right)\end{array}$ & $\begin{array}{l}\text { Total } \\
\mathrm{P}\end{array}$ & $\begin{array}{l}\mathrm{DOC} \\
(\mathrm{mg} \\
\left.\mathrm{L}^{-1}\right)\end{array}$ & $\begin{array}{l}\mathrm{TDN} \\
(\mathrm{mg} \\
\left.\mathrm{L}^{-1}\right)\end{array}$ & $\begin{array}{l}\text { SUVA } \\
254 \\
\left(\mathrm{~L} \mathrm{mg}^{-1}\right. \\
\left.\mathrm{m}^{-1}\right)\end{array}$ & FI \\
\hline Ontonagon & $5 / 27 / 14$ & bdl & bdl & bdl & 21.00 & 14.03 & 0.61 & 3.26 & 1.14 \\
\hline & $7 / 10 / 14$ & bdl & bdl & bdl & 18.27 & 9.27 & 0.51 & 3.53 & 1.16 \\
\hline
\end{tabular}


Appendix Table 3. Dissolved organic carbon (DOC), total dissolved nitrogen (TDN), and specific ultra-violet absorbance at $254 \mathrm{~nm}\left(\mathrm{SUVA}_{254}\right)$ for regional streams measured in summer and spring.

\begin{tabular}{|c|c|c|c|c|c|c|}
\hline Site & Season & Date & $\begin{array}{l}\mathrm{DOC} \\
\left(\mathrm{mg} \mathrm{L}^{-1}\right)\end{array}$ & $\begin{array}{l}\text { TDN } \\
\left(\mathrm{mg} \mathrm{L}^{-1}\right)\end{array}$ & $\begin{array}{l}\mathrm{SUVA}_{254} \\
\left(\mathrm{~L} \mathrm{mg}^{-1} \mathrm{~m}^{-1}\right)\end{array}$ & FI \\
\hline Black Creek & Summer & $8 / 13 / 13$ & 7.25 & 0.30 & 3.29 & 1.22 \\
\hline Gratiot River & Summer & $8 / 16 / 13$ & 6.54 & 0.34 & 3.58 & 1.21 \\
\hline Hills Creek & Summer & $8 / 15 / 13$ & 6.07 & 0.33 & 3.18 & 1.22 \\
\hline Little Garlic River & Summer & $7 / 14 / 13$ & 5.10 & 0.30 & 3.33 & 1.23 \\
\hline Big Pup Creek & Summer & $7 / 12 / 13$ & 2.00 & 0.33 & 3.07 & 1.23 \\
\hline East Branch Huron & Summer & $7 / 11 / 13$ & 9.30 & 0.44 & 3.90 & 1.17 \\
\hline Little Huron & Summer & $7 / 15 / 13$ & 4.30 & 0.33 & 3.89 & 1.19 \\
\hline Pine River & Summer & $7 / 26 / 13$ & 5.89 & 0.21 & 3.46 & 1.17 \\
\hline Mountain Stream & Summer & $7 / 27 / 13$ & 5.94 & 0.25 & 3.18 & 1.15 \\
\hline Ash & Spring & $4 / 26 / 14$ & 11.03 & 0.36 & 4.50 & 1.13 \\
\hline Mud & Spring & $4 / 26 / 14$ & 11.23 & 0.36 & 4.50 & 1.12 \\
\hline Big Cranberry & Spring & $4 / 26 / 14$ & 8.87 & 0.33 & 4.89 & 1.15 \\
\hline Big Iron & Spring & $4 / 26 / 14$ & 11.48 & 0.49 & 4.61 & 1.13 \\
\hline Dreiss & Spring & $4 / 26 / 14$ & 10.47 & 0.44 & 4.45 & 1.16 \\
\hline Duck & Spring & $4 / 26 / 14$ & 8.96 & 0.37 & 4.46 & 1.12 \\
\hline Flintsteel & Spring & $4 / 26 / 14$ & 9.09 & 0.36 & 4.27 & 1.17 \\
\hline Floodwood & Spring & $4 / 26 / 14$ & 9.57 & 0.38 & 4.33 & 1.15 \\
\hline Halfway & Spring & $4 / 26 / 14$ & 8.38 & 0.43 & 4.53 & 1.15 \\
\hline Little Cranberry & Spring & $4 / 26 / 14$ & 9.00 & 0.45 & 4.31 & 1.15 \\
\hline Little Iron & Spring & $4 / 26 / 14$ & 9.76 & 0.38 & 4.51 & 1.14 \\
\hline Mineral & Spring & $4 / 26 / 14$ & 8.29 & 0.39 & 4.17 & 1.15 \\
\hline Pine Creek & Spring & $4 / 26 / 14$ & 9.21 & 0.50 & 4.14 & 1.14 \\
\hline Potato & Spring & $4 / 26 / 14$ & 9.00 & 0.47 & 4.28 & 1.14 \\
\hline Townline & Spring & $4 / 26 / 14$ & 9.27 & 0.38 & 4.29 & 1.14 \\
\hline Union & Spring & $4 / 26 / 14$ & 8.15 & 0.36 & 4.38 & 1.12 \\
\hline Weigel & Spring & $4 / 26 / 14$ & 10.17 & 0.42 & 4.34 & 1.15 \\
\hline Gratiot & Spring & $5 / 2 / 14$ & 8.36 & 0.43 & 3.87 & 1.15 \\
\hline Jacob's Creek & Spring & $5 / 2 / 14$ & 6.46 & 0.63 & 3.80 & 1.17 \\
\hline Montreal River & Spring & $5 / 2 / 14$ & 8.55 & 0.44 & 3.92 & 1.15 \\
\hline Mud Lake Creek & Spring & $5 / 2 / 14$ & 19.52 & 0.49 & 4.32 & 1.14 \\
\hline
\end{tabular}


Appendix Table 3. Continued.

\begin{tabular}{lccrrrr}
\hline Site & Season & Date & \multicolumn{1}{c}{$\begin{array}{l}\text { DOC } \\
\left(\mathrm{mg} \mathrm{L}^{-1}\right)\end{array}$} & $\begin{array}{r}\text { TDN } \\
\left(\mathrm{mg} \mathrm{L}^{-1}\right)\end{array}$ & $\begin{array}{l}\mathrm{SUVA}_{254} \\
\left(\mathrm{~L} \mathrm{mg}^{-1} \mathrm{~m}^{-1}\right)\end{array}$ & FI \\
\hline Silver River & Spring & $5 / 2 / 14$ & 7.74 & 0.34 & 3.48 & 1.15 \\
Tobacco River & Spring & $5 / 2 / 14$ & 13.86 & 0.52 & 4.20 & 1.14 \\
Traverse River & Spring & $5 / 2 / 14$ & 15.88 & 0.46 & 4.30 & 1.11 \\
\hline
\end{tabular}



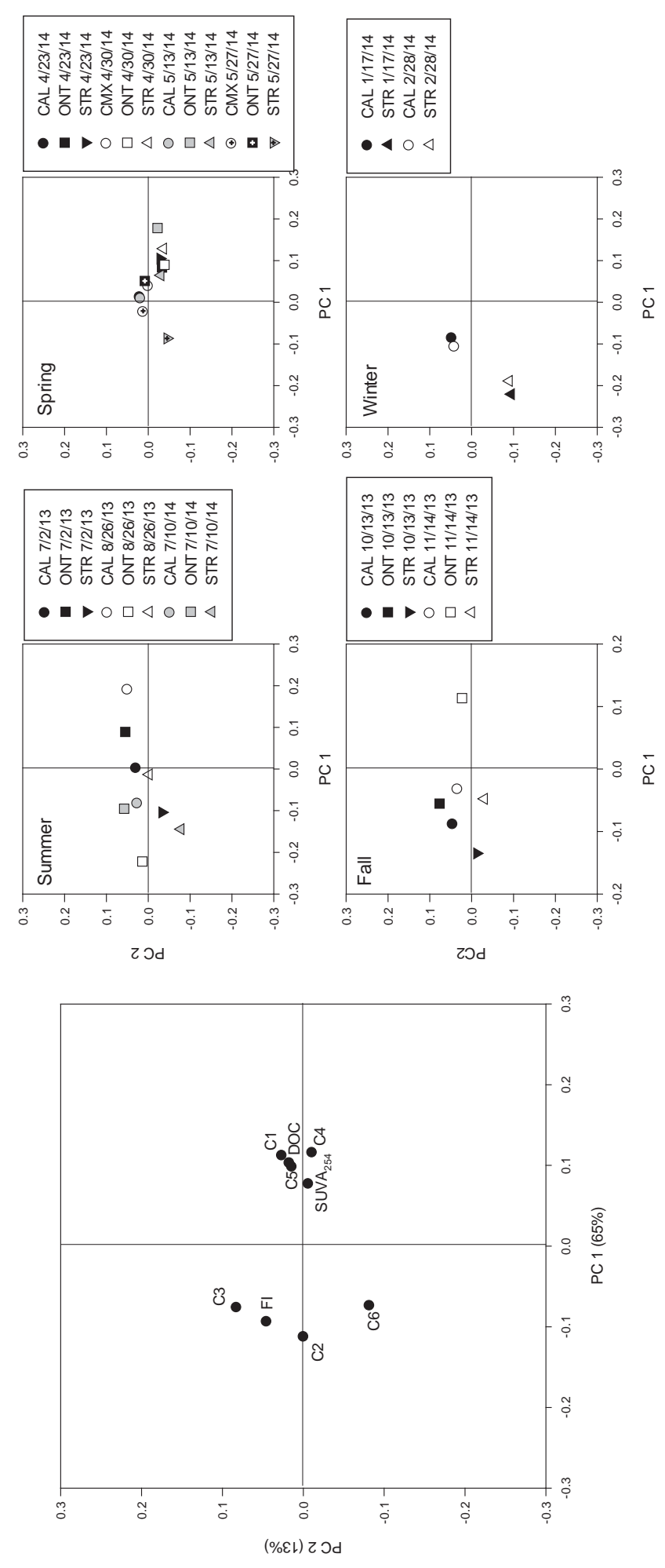

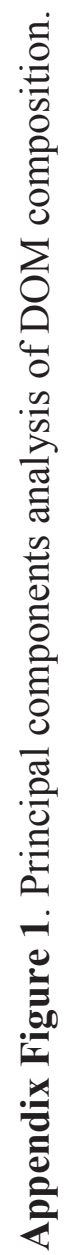


Chapter 4: Linkages among watershed characteristics, DOM composition, and uptake of nitrogen, phosphorus, and carbon in rivers ${ }^{a}$

\author{
Ashley A. Coble ${ }^{1 *}$, Amy M. Marcarelli', Evan S. Kane ${ }^{2,3}$, Casey J Huckins ${ }^{1}$ \\ * corresponding author, Email: aacoble@mtu.edu, Phone: 620200 7696, Fax: 906487 \\ 3167 \\ ${ }^{1}$ Department of Biological Sciences, Michigan Technological University, 1400 Townsend \\ Drive, Houghton, Michigan 49931 \\ ${ }^{2}$ School of Forest Resources and Environmental Science, Michigan Technological \\ University, Houghton, Michigan 49931 \\ ${ }^{3}$ U.S. Forest Service, Northern Research Station, 410 MacInnes; Houghton, Michigan \\ 49931
}

Running head: Nutrient uptake and DOM composition

${ }^{\text {a }}$ This chapter was formatted to be submitted to Limnology and Oceanography. 


\section{Acknowledgements}

We thank B. Borowitz, A.P. Coble, E. Collins, J. Eikenberry, K. Heiden, J.

Kiiskila, T. Matthys, K. Meingast, J. Olson, J. Ortiz, R. Van Goethem, and T. Veverica for field and laboratory assistance. This research was funded by Huron Mountain Wildlife Foundation, Michigan Technological University’s Research Excellence Fund, the USDA McIntire-Stennis Fund, the University of Michigan Water Center with funds from the Fred A. and Barbara M. Erb Family Foundation, and NASA Michigan Space Grant Consortium. A.A.C. was also supported by a fellowship from Michigan Technological University's GK12 Global Watershed program, funded by National Science Foundation award DGE-0841073. 


\begin{abstract}
It is widely acknowledged that cycling of nitrogen $(\mathrm{N})$ and carbon $(\mathrm{C})$ are tightly coupled in streams, yet it is unclear how dissolved organic matter (DOM) composition may alter nutrient uptake. The goal of this study was to determine how DOM composition and other watershed characteristics interacted to influence rates of ammonium $\left(\mathrm{NH}_{4}\right)$, soluble reactive phosphate (SRP), and dissolved organic carbon (DOC) uptake across 11 Lake Superior tributaries. Nutrient uptake velocities ranged from non-detectable to $11.7 \mathrm{~mm}$ $\mathrm{min}^{-1}$ for $\mathrm{NH}_{4}$, non-detectable to $7.2 \mathrm{~mm} \mathrm{~min}^{-1}$ for $\mathrm{SRP}$, and non-detectable to $3.1 \mathrm{~mm}$ $\min ^{-1}$ for DOC. Multiple linear regression models revealed that fluorescence index (FI), $\mathrm{NH}_{4}$ concentration, and canopy cover explained $69 \%$ of the variability in $\mathrm{NH}_{4}$ uptake velocities $\left(\mathrm{V}_{\mathrm{f}}\right)$, and DOC concentration explained $90 \%$ of the variability in SRP $\mathrm{V}_{\mathrm{f}}$. Multivariate analysis further identified FI as an important predictor of $\mathrm{NH}_{4} \mathrm{~V}_{\mathrm{f}}$ across these rivers, with increasing composition of terrestrially-derived DOM resulting in $\mathrm{NH}_{4}$ being taken up more quickly. Our results suggest that DOM composition along with DOC concentration may be important, yet often overlooked, predictors of $\mathrm{NH}_{4}$ and SRP uptake in streams. Moreover, our estimates of nutrient uptake lengths suggest that DOC and SRP are likely exported from our study streams to Lake Superior without measureable uptake, potentially supplying important nutrient and energy sources to the near-shore region.
\end{abstract}




\section{Introduction}

In aquatic ecosystems dissolved organic matter (DOM) exerts a strong influence on physical, chemical, and biological characteristics, all of which play an integral role in biogeochemical cycling (Maranger and Pullin 2003, Prairie 2008, Webster et al. 2008). For example, DOM can bind trace elements, affect water transparency, alter rates of metabolism, and undergo photodegradation and microbial processing. DOM is comprised of a complex mixture of organic acids and molecules and these components originate from a variety of organic matter pools, each of which can undergo biogeochemical transformations, further contributing to the complexity of DOM found within aquatic ecosystems (Thurman 1985, McKnight et al. 2003).

Watershed characteristics can also contribute to variability in river DOM concentration and character (Gergel et al. 1999, Frost et al. 2006, Yamashita et al. 2011). For example, Frost et al. (2006) found that DOM concentration was related to watershed morphology, landcover, and wetland type, but DOM physicochemical properties (e.g. molecular weight, spectral indices) were related to lake and wetland area. In another study, land cover and nutrient concentrations were more strongly related to DOC concentration than DOM composition, further supporting the concept that watershed characteristics may influence DOM concentration and composition differently (Larson et al. 2014). Clearly, watershed characteristics serve an important role in determining DOC concentration and composition in aquatic ecosystems.

Uptake and cycling of $\mathrm{C}$ and $\mathrm{N}$ are tightly coupled in small streams (Bernhardt and Likens 2002, Sobczak et al. 2003), yet studies do not typically consider DOM composition as a potential predictor of variability in nutrient uptake rates. Additions of 
labile $\mathrm{C}$ to a small temperate stream in the eastern U.S.A. resulted in shortened uptake lengths of both ammonium $\left(\mathrm{NH}_{4}\right)$ and nitrate $\left(\mathrm{NO}_{3}\right)$, suggesting that an increase in bioavailable C increases demand for inorganic N (Bernhardt and Likens 2002).

Furthermore, an experimental laboratory incubation of stream water with amendments of $\mathrm{NH}_{4}$ and labile $\mathrm{C}$ revealed $\mathrm{C}$ mineralization rates were limited by $\mathrm{NH}_{4}$ or co-limited by $\mathrm{NH}_{4}$ and labile $\mathrm{C}$ during much of the year (Coble et al., in review). Given the tight reciprocal coupling of $\mathrm{C}$ and $\mathrm{N}$ in streams, and the potential role of $\mathrm{C}$ quantity and quality in controlling $\mathrm{N}$ uptake, simultaneous measurements of both DOM composition and nutrient uptake metrics could, collectively, provide insight into mechanisms responsible for spatial variability in nutrient uptake among watersheds.

Variability in biological, physical, \& chemical characteristics among streams can directly or indirectly affect nutrient cycling. Previous studies of in-stream nutrient uptake of $\mathrm{N}$ and $\mathrm{P}$ have found that processing rates are influenced by a variety of characteristics in and among watersheds including: stream size (Peterson et al. 2001), riparian vegetation (Sabater et al. 2000), climate variability (Mulholland 1992), autotrophic activity (Hall and Tank 2003), and nutrient inputs (point source or eutrophication; Alexander et al. 2000; Marti et al. 2004). Furthermore, variability in biological, physical, and chemical characteristics could indirectly affect nutrient cycling through alteration of DOM concentration and composition. Existing variability in biological, physical, and chemical characteristics within watersheds likely contributes to variability in DOM composition, in-stream nutrient uptake, and ultimately the quality and form of elements exported to downstream rivers, lakes, and oceans. 
What is the role of DOM composition and other watershed characteristics in controlling among-stream variability in nutrient uptake rates? Here, we applied shortterm nutrient releases of $\mathrm{N}, \mathrm{P}$, and $\mathrm{C}$ to streams and characterized DOM composition to determine whether variability in DOM composition or other biological, physical and chemical characteristics are related to nutrient uptake in forested tributary streams of Lake Superior. In this study we address two overarching hypotheses: 1) watershed characteristics (defined as: watershed area, wetland percent, and discharge) influence variability in physical, chemical, and biological characteristics; and 2) physical, chemical, and biological characteristics (defined as: $\mathrm{NH}_{4}, \mathrm{SRP}, \mathrm{DOC}$, TDN concentrations, benthic chlorophyll a, percent canopy cover, stream water temperature, and $\mathrm{pH}$ ) and DOM character will influence nutrient uptake velocities.

\section{Methods}

Study sites-All study sites were located along the south shore of Lake Superior in Michigan's Upper Peninsula (Figure 11). We selected small to mid-size tributaries situated near the shoreline of Lake Superior exhibiting a range in watershed area from 1.7 to $124.2 \mathrm{~km}^{2}$ (Table 9) and where some previous measurements of riverine characteristics (e.g., discharge) have been conducted. Bedrock among these sites consists of Precambrian sedimentary and volcanic formations (Table 9) and overstory vegetation is predominately comprised of northern hardwood forests. Mean annual precipitation (1983-2013) in the region is $\sim 80 \mathrm{~cm}$ (National Atmospheric Deposition Program (NADP), station MI99, Chassell Michigan, available from: 
http://nadp.sws.uiuc.edu/data/) with up to $50 \%$ of annual precipitation received as snow (Stottlemyer 1997).

Watershed characteristics and stream chemistry-Watershed characteristics across the study sites varied in watershed area (2 to $124 \mathrm{~km}^{2}$ ), wetland percent (1 to $30 \%$ ), and riverine distance to Lake Superior (0.2 to $22.6 \mathrm{~km}$; Table 9). Background $\mathrm{NH}_{4}$ concentrations were relatively low across the study sites, and exceeded $10 \mu \mathrm{g} \mathrm{L}^{-1}$ at only two of the study sites (Little Huron and Salmon Trout; see Appendix Table 4). Background SRP concentrations were also low across all sites (below $4.2 \mu \mathrm{g} \mathrm{L}^{-1}$ ) and background DOC concentrations ranged from 2.0 to $9.3 \mathrm{mg} \mathrm{L}^{-1}$ (see Appendix Table 4). Additional biological, physical, and chemical stream characteristics are reported in the Web Appendix (see Appendix: Tables 4 and 5).

Nutrient uptake measurements-We quantified whole-stream uptake of $\mathrm{NH}_{4}$, soluble reactive phosphate (SRP), and DOC using nutrient spiraling techniques (Stream Solute Workshop 1990). Nutrient injections were conducted at six study sites in July 2012 and at eleven study sites in July or August 2013. Five additional sites were added in 2013 to increase the spatial distribution of our sampling. Reaches with little to no tributary inputs were selected to target a travel time of 40 minutes to one hour; reaches ranged in length from 200 to $1000 \mathrm{~m}$. At all sites we conducted a short-term release of both $\mathrm{NH}_{4}$ and $\mathrm{PO}_{4}$ (added together) by pumping a solution of nutrients as $\mathrm{NH}_{4} \mathrm{Cl}$ and $\mathrm{KH}_{2} \mathrm{PO}_{4}$ and a conservative tracer (rhodamine WT) continuously into the stream at a constant rate of $100 \mathrm{~mL} / \mathrm{min}$. In a subset of 6 streams (Calumet, Big Pup, Little Huron, Little Garlic, E. Branch Huron, Salmon Trout), we conducted a second addition of $\mathrm{C}\left(\mathrm{C}_{12} \mathrm{H}_{22} \mathrm{O}_{11}\right)$ and a conservative tracer (rhodamine WT) at least one hour (and in some cases more than one 
day) after the conclusion of the $\mathrm{NH}_{4}$ and $\mathrm{PO}_{4}$ injection. Our measurements of $\mathrm{C}$ uptake were limited by stream size and analytical ability to detect small differences in DOC concentrations. We targeted an increase in background nutrient concentrations of $12 \mu \mathrm{g}$ $\mathrm{L}^{-1}$ for $\mathrm{NH}_{4}$ and $\mathrm{PO}_{4}, 5 \mathrm{mg} \mathrm{L}^{-1}$ for DOC, and $7 \mu \mathrm{g} \mathrm{L}^{-1}$ for rhodamine WT; because we did not have background nutrient information prior to conducting injections for some study sites, this resulted in enrichment factors (enrichment/background concentrations) ranging from 1.4 to 5.9 for $\mathrm{NH}_{4}, 1.6$ to 6.6 for $\mathrm{SRP}$, and 1.2 to 2.8 for DOC. We only attempted to measure DOC uptake at the Salmon Trout River in 2012 because we were unable to achieve the desired $5 \mathrm{mg} \mathrm{L}^{-1}$ increase in DOC concentration due to its large size.

Within each study reach, seven or more sampling locations were established downstream of the site of the nutrient addition where replicate samples of filtered water $(0.45 \mu \mathrm{m})$ were collected for analysis of background concentrations of $\mathrm{N}, \mathrm{P}$, and $\mathrm{C}$ prior to the addition of nutrients. We then initiated the addition and after the conservative tracer reached a plateau concentration at the downstream end of the reach ( $\sim 40$ minutes to 1 hour), we again collected replicate samples from all sampling locations. Additional water samples were collected from above the nutrient addition site to confirm that background conditions did not change during the nutrient addition.

To determine nutrient uptake lengths $\left(\mathrm{S}_{\mathrm{w}}\right)$, background-corrected nutrient concentrations (plateau minus background concentration) were normalized for the conservative tracer concentrations and the natural log of these values were plotted against distance from the nutrient addition site (Stream Solute Workshop 1990). If the linear regression was significant $(\alpha=0.10), S_{\mathrm{w}}$ was then calculated as the inverse slope of the regression line (Stream Solute Workshop 1990) using the slope of the line $\left(\mathrm{k}_{\mathrm{w}}\right)$ : 


$$
S_{w}=\frac{1}{k_{w}}
$$

From $\mathrm{S}_{\mathrm{w}}$ we calculated uptake velocity $\left(\mathrm{V}_{\mathrm{f}} ;\right)$ :

$$
V_{f}=\frac{(u \times z)}{S_{w}}
$$

where $\mathrm{u}=$ velocity, $\mathrm{z}=$ depth.

We used $\mathrm{S}_{\mathrm{w}}$ to assess how far a nutrient travels before it is taken up in relation to the total stream distance prior to entering Lake Superior. Because $S_{\mathrm{w}}$ is highly influenced by discharge (Davis and Minshall 1999; Hall et al. 2002), we used $\mathrm{V}_{\mathrm{f}}$ to compare nutrient uptake among sites and years with varying discharge.

Dissolved organic matter character - For determination of DOM character filtered $(0.45$ $\mu \mathrm{m})$ water samples were collected on the dates of each nutrient injection and stored in a refrigerator $\left(1.6^{\circ} \mathrm{C}\right)$ until analyzed. As an indicator of $\mathrm{C}$ aromaticity, ultraviolet (UV) absorbance at $254 \mathrm{~nm}$ was determined on room temperature background water samples from all nutrient injections using a Thermo Scientific 10s UV-Vis spectrophotometer, and used to calculate specific ultraviolet absorbance (SUVA 254$)$, defined as the UV absorbance at $254 \mathrm{~nm}$ wavelength divided by the DOC concentration (Weishaar et al. 2003).

To characterize the chemical composition of DOC we determined fluorescence excitation-emission fluorescence matrices (EEM) with a Jobin-Yvon Horiba Fluoromax$3^{\mathrm{TM}}$ fluorometer in 2013 only (Jobin Yvon Horiba, France). EEMs were collected on room-temperature water samples every $3 \mathrm{~nm}$ over excitation wavelength intervals between 240 and $600 \mathrm{~nm}$, and every $3.28 \mathrm{~nm}$ over emission wavelength intervals between 212 and $620 \mathrm{~nm}$. Fluorescence spectra were corrected for the inner filter effect, and a 
Raman normalized Milli-Q water sample was removed from each fluorescence spectrum. Fluorescence index (FI), which can be used to distinguish sources of aquatic and fulvic acids, was defined as the ratio of the emission intensity at $450 \mathrm{~nm}$ to $550 \mathrm{~nm}$ acquired with an excitation of $370 \mathrm{~nm}$ (McKnight et al. 2001), and was identified from corrected sample EEMs.

Parallel factor analysis (PARAFAC) was used to further identify fluorescing components detected using EEMs (Stedmon et al. 2003, Cory and McKnight 2005), and was completed using the PLS-toolbox for Matlab (Eigenvector Research Inc.). In addition to samples from this study we used a variety of samples $(n=374)$ to develop a robust PARAFAC model (e.g., Stedmon and Bro 2008). Samples were comprised primarily of regional river samples, but also included samples from Lake Superior's near shore region, soil lysimeter samples, and precipitation samples collected within one of the study watersheds. The PARAFAC model was validated with split-half analysis and by examining residuals (Stedmon et al. 2003, Stedmon and Bro 2008). This analysis of the fluorescence spectra identified six components, and split-half analysis identified 92.5\% similarity among splits. Each of these six components ( $\mathrm{C} 1$ to $\mathrm{C} 6)$ has been previously described for aquatic systems (Table 10). C1 was identified as a fulvic-like peak, C2, C3, and $\mathrm{C} 5$ were identified as humic-like peaks, $\mathrm{C} 4$ was identified as containing both fulviclike and humic-like peaks, and C6 was identified as the protein-like component tryptophan (Table 10). C6 was the only autochthonous-derived component identified. Hereafter, reference to these six components will be expressed as a percentage of all fluorescent DOM. 
Watershed characteristics - To identify variability in watershed characteristics among our study sites, we used ESRI Arc Geographic Information System (GIS) Desktop, Version 10.1. Geospatial datasets were downloaded from the U.S. Geological Survey: the National Elevation Dataset (NED, http://ned.usgs.gov), the National Hydrography Dataset (NHD, http://nhd.usgs.gov), and the National Land Cover Dataset (NLCD, http://www.mrlc.gov). Wetlands polygons from the National Wetlands Inventory (NWI) were acquired from U.S. Fish and Wildlife Service (U.S. Fish and Wildlife Service, Division of Habitat and Resource Conservation, September 26, 2011, Washington D.C., http://www.fws.gov/wetlands/)

To delineate boundaries and calculate areas of watersheds for each study site, we used the Hydrology toolset found in Arc Toolbox under spatial analysis tools. We used sample points determined with Global Positioning System (GPS) at the downstream end of our sampling reach and the NED data to delineate the individual watersheds for each of our sample locations. Therefore, watershed area includes only the area above our sampling locations. Watershed boundaries were used to clip the NWI data to determine the percent total wetland area within each watershed. The length of the polyline in the NHD drainage networks was used to determine the distance from our study sites to Lake Superior. The NHD drainage networks did not include two of our study streams (Calumet watershed and Black Creek), thus we used flow accumulation data layers, which were derived from the NED and were created as part of the watershed delineation, to determine the distance from our study reach to Lake Superior. Reach-level chemical, physical, and biological characteristics-To identify potential factors that may affect variability in nutrient uptake and DOM character among sites we 
also measured discharge, canopy cover, water temperature, background nutrient concentrations, and periphyton biomass on each sampling date. Discharge was determined by measuring velocity along a transect within the nutrient uptake reach using a Flomate flow meter and wading rod. At Calumet watershed, discharge is continuously monitored using a Parshall flume equipped with a Li-Cor datalogger (Li-Cor, Lincoln, Nebraska) and Stevens pressure transducer (Stevens Water Monitoring Systems Inc., Portland Oregon; Stottlemyer and Toczdylowki 2006), and an established stage-discharge relationship allowed for on-site determination of discharge on each sampling date. We measured canopy cover as a proxy for light availability at $\geq 7$ locations along each stream reach using a densiometer. A YSI multiparameter sonde that measured water temperature, dissolved oxygen, turbidity, conductivity, and $\mathrm{pH}$ at one minute intervals was deployed upon arrival at the downstream end of the reach. Background nutrient concentrations of $\mathrm{NH}_{4}, \mathrm{SRP}$, and DOC were collected as part of nutrient uptake measurements and analyzed as described below.

To determine periphyton biomass as chlorophyll a, we collected samples at each of the water sampling locations $(\geq 7)$ at each stream. Chlorophyll a provides an estimate of algal biomass and can be used to differentiate algal biomass from other organic materials (Steinman et al. 2007). On the date of each nutrient injection we collected samples of the dominant substrate as either rocks or fine sediment at each sampling location. We collected the top $1 \mathrm{~cm}$ of sediment using a $2 \mathrm{~cm}$ diameter core. Rocks were scrubbed into approximately $150 \mathrm{~mL}$ of water and a subsample of the resulting slurry was filtered through pre-ashed GF/F filters. The filters were kept frozen until laboratory analysis. Periphyton chlorophyll a was analyzed using the spectrophotometric method 
(APHA 2005, Nusch 1980). After analysis, the planar rock shape was traced and weighed to determine the surface area of the rocks (Bergey and Getty 2006).

Ammonium was analyzed on the day of sample collection using a fluorometric method (Holmes et al. 1999, adapted by Taylor et al. 2007) and analyzed with either an Aquafluor handheld fluorometer or a Turner Trilogy fluorometer (Turner Designs, Sunnyvale, California). All SRP samples were frozen until laboratory analysis using the ascorbic acid method (APHA 2005) and analyzed on a Thermo Scientific Gensys10s UVVis spectrophotometer. DOC samples were kept $\operatorname{cool}\left(4^{\circ} \mathrm{C}\right)$ until laboratory analysis, when they were acidified with hydrochloric acid for quantification of DOC and total dissolved N (TDN) concentrations using a TOC-5000A analyzer (Shimadzu Scientific Instruments, Columbia Maryland). Rhodamine WT concentrations were analyzed with an Aquafluor handheld fluorometer (Turner Designs, Sunnyvale, California) within five hours of collection. To characterize additional stream water chemistry at each site we also analyzed fluoride $\left(\mathrm{F}^{-}\right)$, chloride $\left(\mathrm{Cl}^{-}\right)$, nitrite $\left(\mathrm{NO}_{2}^{-}\right)$, bromide $(\mathrm{Br})$, nitrate $\left(\mathrm{NO}_{3}^{-}\right)$, phosphate $\left(\mathrm{PO}_{4}{ }^{3-}\right)$, and sulfate $\left(\mathrm{SO}_{4}{ }^{2-}\right)$ on a Dionex Ion Chromatograph and total phosphorus by performing an ammonium persulfate digestion method followed by the ascorbic acid method (APHA 2005). When nutrient concentrations were below our detection limit they were replaced with a value of $1 / 2$ the detection limit for inclusion in models, and are reported as such in Appendix Table 4.

Statistical analyses - We used a principal components analysis (PCA) to examine relationships among watersheds and DOC characteristics. DOC characteristics included in this analysis were: the six fluorescence components identified by PARAFAC (C1-C6; expressed as a percentage of fluorescent DOM), DOC concentration, SUVA 254 , and FI. 
To further identify how DOC or watershed characteristics or chemical, physical, and biological variables perform as predictors of nutrient uptake we used partial least squares (PLS) with uptake velocity as the response variable and the following as predictor variables: watershed area, stream temperature, discharge, percent wetland area, canopy cover percent, conductivity, dissolved oxygen, $\mathrm{pH}$, benthic chlorophyll a, TDN, $\mathrm{NH}_{4}, \mathrm{SRP}, \mathrm{DOC}, \mathrm{FI}, \mathrm{SUVA}_{254}, \mathrm{C} 1, \mathrm{C} 2, \mathrm{C} 3, \mathrm{C} 4, \mathrm{C} 5$, and C6. PLS is a multivariate approach where variance in the predictors is used to explain variance in the response, and which is less sensitive than multiple regression to correlation among predictor variables and deviations from normality. Within a PLS biplot, the location of the variables indicates the correlation structure such that variables situated near each other are positively correlated, variables situated opposite each other are negatively correlated, and variables situated near the origin have very little influence on the overall model. Any variable situated a greater distance from the origin has a greater overall influence on the model (Kothawala et al. 2014). The importance of a variable on the overall model was determined by the variable importance on the prediction (VIP) scores. VIP scores $\geq 2$ were considered highly influential, between 1 and 2 as moderately influential, and $<1$ as less influential. Because SRP and DOC $\mathrm{V}_{\mathrm{f}}$ was not detectable at the majority of the sites sampled (see results below), we were only able to conduct this analysis with $\mathrm{NH}_{4} \mathrm{~V}_{\mathrm{f}}$. Two sites (Little Huron and the Salmon Trout) without significant $\mathrm{NH}_{4}$ uptake were excluded. For both PCA and PLS analysis we identified outliers as samples exceeding the $95 \%$ confidence limit in the Hotelling's $\mathrm{T}^{2}$ analysis. Internal cross validation was performed to test the repeatability of the analysis and validate the model. PCA and PLS 
analyses were performed using MATLAB $\left(\right.$ MATLAB $\left.^{\circledR}\right)$ with the PLS Toolbox (Eigenvector Research Inc.).

Multiple linear regression was also used to determine whether biological, chemical, or physical variables were significant predictors of uptake velocity of $\mathrm{NH}_{4}$ or SRP. Given the lack of significant uptake of DOC amongst many of our study sites we did not model predictors of DOC $\mathrm{V}_{\mathrm{f}}$. We expected watershed characteristics (watershed area, percent wetland area, and discharge) to affect physical (temperature, light) and chemical characteristics (nutrient concentrations, DOM character), which in turn affect nutrient uptake. Therefore, we excluded watershed characteristics which were highly correlated with other parameters from this modeling approach to isolate the effects of physical, chemical, and biological parameters on nutrient uptake velocity. Additionally some physical, chemical, and biological parameters were excluded due to correlations with other parameters. We measured or calculated the following variables for inclusion in regression models as potential predictors of nutrient uptake velocity $\left(\mathrm{V}_{\mathrm{f}}\right)$ : fluorescence index, $\mathrm{SUVA}_{254}$, canopy cover, stream water temperature, benthic chlorophyll a, $\mathrm{pH}$, and concentrations of DOC, $\mathrm{NH}_{4}, \mathrm{SRP}$, and $\mathrm{TDN}$. One covariate, $\mathrm{pH}$, was removed prior to model selection because it was significantly correlated $(p>0.05)$ with $\mathrm{SUVA}_{254}$. Due to our limited sample size, we a priori limited models to a maximum of three predictors for $\mathrm{NH}_{4} \mathrm{~V}_{\mathrm{f}}$ and one predictor for SRP $\mathrm{V}_{\mathrm{f}}$. Additionally, we only constructed regression models for 2013 because all streams were sampled and DOM characteristics were quantified in 2013 only. Only sites with significant uptake were included in this modeling approach, resulting in two sites excluded from the $\mathrm{NH}_{4}$ model and 7 sites excluded from the SRP model. Akaike's information criteria (AIC) were used to evaluate 
models. We identified the best model(s) based on the smallest AIC and we only considered models greater than two AIC units from the null model (Burnham and Anderson 2002).

\section{Results}

Nutrient uptake metrics - Across our study sites, $\mathrm{NH}_{4} \mathrm{~V}_{\mathrm{f}}$ ranged from non-detectable to $11.7 \mathrm{~mm} \mathrm{~min}^{-1}$ in 2013 and from non-detectable to $5.7 \mathrm{~mm} \mathrm{~min}^{-1}$ in 2012 . We observed significant uptake of $\mathrm{NH}_{4}$ at all of our study sites on at least one date except Little Huron (Fig. 12). There were similarities in $\mathrm{NH}_{4} \mathrm{~V}_{\mathrm{f}}$ among years (Fig. 12). For example, the East Branch of the Huron had the fastest $\mathrm{V}_{\mathrm{f}}$ measured among study sites in both years, while there was no significant uptake of $\mathrm{NH}_{4}$ in the Little Huron in either year. The Salmon Trout was the only site where uptake of $\mathrm{NH}_{4}$ was observed in 2012, but not 2013 (Fig. 12). Additional parameters of nutrient uptake can be found in Appendix Table 6. Across sites, SRP $V_{\text {f }}$ ranged from non-detectable to $7.2 \mathrm{~mm} \mathrm{~min}^{-1}$ in 2012 and from non-detectable to $1.2 \mathrm{~mm} \mathrm{~min}^{-1}$ in 2013. Significant uptake of SRP was observed at three sites in 2012 and four sites in 2013, but only one of these sites, Big Pup Creek, had significant uptake of SRP in both years (Fig. 12). Two sites with significant uptake of SRP, Black Creek and Hills Creek, were studied in 2013 only (Fig. 12). The observed SRP uptake velocities were 1.5 to $6 x$ greater in 2012 than in 2013, and at Big Pup SRP $V_{f}$ was $11 x$ greater in 2012 than in 2013.

Across sites and years, DOC $\mathrm{V}_{\mathrm{f}}$ ranged from non-detectable to $3.1 \mathrm{~mm} \mathrm{~min}^{-1}$, with a single measurement of $0.6 \mathrm{~mm} \mathrm{~min}^{-1}$ in 2012 and a range from 2.4 to $3.1 \mathrm{~mm} \mathrm{~min}^{-1}$ in 2013.We observed significant uptake of DOC at only one of the six sites in 2012 and two 
of the five sites in 2013. Significant uptake of $\mathrm{NH}_{4}, \mathrm{SRP}$, and DOC only occurred at one site, Big Pup Creek, and this occurred in both years. Additional parameters of nutrient uptake can be found in Appendix Table 7.

DOM characteristics - Quantifiable differences in $\mathrm{SUVA}_{254}$, FI, and fluorescing components identified by PARAFAC indicate variability in DOC chemical characteristics among sites. $\mathrm{SUVA}_{254}$, an indicator of $\mathrm{C}$ aromaticity, ranged from 2.43 to $3.75 \mathrm{~L} \mathrm{mg}^{-1} \mathrm{~m}^{-1}$ across study sites in 2012 and from 3.07 to $3.90 \mathrm{~L} \mathrm{mg}^{-1} \mathrm{~m}^{-1}$ in 2013 (see Appendix: Table 5). In both 2012 and 2013 the lowest SUVA254 values were observed at Big Pup and the greatest $\mathrm{SUVA}_{254}$ values were observed at East Branch of the Huron (see Appendix: Table 5). Fluorescence index (FI) ranged from 1.15 to 1.23 among sites in 2013; FI values below 1.2 are characteristic of terrestrially derived fulvic acids and FI values above 1.7 are characteristic of microbially-derived fulvic acids (McKnight et al. 2001). Although the observed values are tightly constrained and indicative of terrestrially derived fulvic acids, there is a trend of decreasing fluorescence index with increasing stream size $\left(F_{(1,9)}=7.8, p=0.02, r^{2}{ }_{\text {adj }}=0.40\right.$; Fig. 13).

The PCA model of DOM characteristics identified four principal components that collectively explained $97 \%$ of the variability in the model. DOM characteristics explained most of the variability along the first principal component axis, which explained $63.4 \%$ of the variability in the model: $\mathrm{C} 1$ (fulvic-like), $\mathrm{C} 4$ (fulvic and humiclike), and C5 (humic-like) all had strong positive loadings while C2 (humic-like), C3 (humic-like), and C6 (tryptophan-like) all had strong negative loadings (Table 11). Separation along the first axis generally corresponded to components with longer emission wavelengths positioned on the right $(\mathrm{C} 1, \mathrm{C} 4, \mathrm{C} 5)$ and components with shorter 
emission wavelengths positioned on the left (C3, C2, C6; Fig. 14). The exception to this was that $\mathrm{C} 1$ and $\mathrm{C} 2$, which were located on opposing ends of PC 1, had similar, midrange emission wavelengths. The second principal component explained $18.5 \%$ of the variability in the model, with fluorescence index with positive loadings and DOC concentration and $\mathrm{SUVA}_{254}$ with strong negative loading (Table 11). The third and fourth principal components explained $9 \%$ of the variability in the model with positive DOC loadings and $6 \%$ of the variability in the model with positive $\mathrm{SUVA}_{254}$ loadings (Table 11).

Three rivers with larger watershed areas (Mountain, Pine, and Salmon Trout) were located primarily in the lower left hand quadrant of the PCA, indicating greater percentages of C3 (humic-like), C2 (humic-like), C6 (tryptophan-like) DOM components and greater DOC concentration and $\mathrm{SUVA}_{254}$ compared to other sites (Fig. 4). However, the second largest river, the Salmon Trout River, was located near the origin, and therefore less influenced by the DOM composition characteristics $(\mathrm{C} 3, \mathrm{C} 3$, and $\mathrm{C} 6)$ than the other two sites. The third largest river, East Branch of the Huron, was located in the lower right quadrant, indicating high concentrations of DOC and SUVA 254 , but in contrast to the other large rivers DOM displayed greater C1 (fulvic-like), C4 (fulvic and humic-like), and C5 (humic-like). The smallest river, Calumet, was also in this quadrant, with DOM with high C1, C4, and C5. Most other sites (Little Garlic, Black, Gratiot, and Little Huron) displayed moderately positive loadings along the PC1 axis. One other site, Big Pup Creek, was found to have slightly negative loadings along the PC1 axis. This site also revealed the greatest positive loadings along the PC2 axis, indicating greater FI (Fig. 14). 
Predictors of nutrient uptake velocity - The PLS model provided information about potential factors driving $\mathrm{NH}_{4} \mathrm{~V}_{\mathrm{f}}$ and identified 4 latent variables (LV), which collectively explained $95.5 \%$ of the variance in $\mathrm{NH}_{4} \mathrm{~V}_{\mathrm{f}}\left(\mathrm{R}^{2} \mathrm{Y}=0.955\right)$ and $80.9 \%$ of the variance in the predictor variables $\left(\mathrm{R}^{2} \mathrm{X}=0.809\right)$. Here, we report the two $\mathrm{LVs}$ that explained the most variability. The first latent variable axis (LV1) explained $\sim 28 \%$ of the variability in the $\mathrm{X}$ variables and $79.8 \%$ of the variability in the $\mathrm{Y}$ variable $\left(\mathrm{NH}_{4} \mathrm{~V}_{\mathrm{f}}\right)$. LV1 was a function of watershed characteristics; discharge, watershed area, and water temperature were all tightly clustered with positive loadings, and FI, dissolved oxygen, and C5 had strong negative loadings (Fig. 15a). The second latent variable axis explained $\sim 34 \%$ of the variability in the $\mathrm{X}$ variables and $8.6 \%$ of the variability in the $\mathrm{Y}$ variable. Along the LV2 axis TDN, DOC, $\mathrm{C} 1$, and $\mathrm{C} 4$ all had positive loadings, and $\mathrm{C} 2$ and $\mathrm{C} 6$ had negative loadings (Fig. 15a).

PLS analysis identified discharge, watershed area, and FI as highly influential predictors of $\mathrm{NH}_{4} \mathrm{~V}_{\mathrm{f}}$. Conductivity, dissolved oxygen, SUVA, temperature, $\mathrm{SRP}$, and chlorophyll a were identified as moderately influential predictors, while all other factors were less influential predictors of $\mathrm{NH}_{4} \mathrm{~V}_{\mathrm{f}}$ (Fig. 15a). Positioning within the biplot suggests discharge and watershed area were positively correlated with $\mathrm{NH}_{4} \mathrm{~V}_{\mathrm{f}}$ and FI was negatively correlated with $\mathrm{NH}_{4} \mathrm{~V}_{\mathrm{f}}$ (Fig. 15). FI was also situated near conductivity indicating a strong positive correlation between these variables. Also apparent from the biplot of the PLS model is that watershed area and correlated variables (discharge and stream water temperature) were situated opposite of FI, indicating a strong negative correlation among these predictor variables. $\mathrm{NH}_{4}$ concentration was found at the origin, suggesting it did not have a strong overall influence on the model. 
Multiple regression models, which included only sites with detectable $\mathrm{NH}_{4}$ uptake and excluded highly correlated watershed characteristics, resulted in three significant models that predicted $\mathrm{NH}_{4}$ uptake velocity (Table 12). The best model explained $69 \%$ of the variance, had an Akaike weight of 0.58 , and included FI, $\mathrm{NH}_{4}$ concentration, and percent canopy cover as predictor variables (Table 12). The second best model included the predictors $\mathrm{FI}$ and $\mathrm{NH}_{4}$ concentration, which explained $65 \%$ of the variance in $\mathrm{NH}_{4} \mathrm{~V}_{\mathrm{f}}$ and had an Akaike weight of 0.42 (Table 12). The only significant single predictor model was for FI, which alone explained $44 \%$ of the variability in $\mathrm{NH}_{4} \mathrm{~V}_{\mathrm{f}}$. However, because its AIC was greater than 2 units from the best model, it was not considered one of the top models for predicting $\mathrm{NH}_{4} \mathrm{~V}_{\mathrm{f}}$ nor was it considered in calculation of Akiake weights.

There was one significant multiple regression model explaining the variability in SRP uptake velocity, which was a single predictor model with DOC concentration as a predictor variable (Table 12). This model explained $90 \%$ of the variability in SRP $\mathrm{V}_{\mathrm{f}}$ (Table 12).

\section{Discussion}

Despite wide acknowledgment of the linkages between $\mathrm{C}, \mathrm{N}$, and $\mathrm{P}$ cycling in aquatic ecosystems, no studies have incorporated DOM composition into studies of uptake of $\mathrm{N}, \mathrm{P}$, or $\mathrm{C}$ in streams and rivers. Here, we demonstrate that DOM character was an important explanatory variable of uptake of $\mathrm{N}$ and $\mathrm{P}$ in the forested streams included in our study. In turn, some of these DOM characteristics were influenced by watershed characteristics like size. Furthermore, our results indicate that $\mathrm{C}$ and $\mathrm{P}$ are likely exported from our study streams to Lake Superior without measureable uptake, 
potentially supplying important nutrient and energy sources to the near-shore region of Lake Superior. However, ammonium $\mathrm{N}$ is quickly taken up in streams, suggesting that in-stream dynamics may closely regulate the delivery of $\mathrm{N}$ to Lake Superior from its tributaries.

Drivers of nutrient uptake and linkages between $C, N$, and $P-$ Consistencies among the PLS and multiple regression analyses support our hypothesis that DOM composition is an important predictor of in-stream nutrient uptake but also highlights the role of watershed size and its effect on chemical and physical variables. Both the PLS and multiple regression analysis indicated that FI was an important predictor of $\mathrm{NH}_{4} \mathrm{~V}_{\mathrm{f}}$, along with watershed area and discharge. Multiple regressions also identified canopy cover and $\mathrm{NH}_{4}$ concentration as important predictors. Of these covariates, the multivariate analysis indicated $\mathrm{NH}_{4}$ concentrations did not have a strong overall influence on the PLS model. Canopy cover had a negative correlation with $\mathrm{NH}_{4} \mathrm{~V}_{\mathrm{f}}$; therefore, $\mathrm{NH}_{4} \mathrm{~V}_{\mathrm{f}}$ increased as light availability increased (and canopy cover decreased). This finding is consistent with a previous study that found an increase in light availability following riparian tree removal resulted in an increase in $\mathrm{NH}_{4}$ uptake (Sabater et al. 2000). Collectively our findings indicate that as watershed size and discharge increase, canopy cover and FI decrease, and $\mathrm{NH}_{4} \mathrm{~V}_{\mathrm{f}}$ increases.

To our knowledge no studies have specifically addressed the relationship among DOM composition and $\mathrm{P}$ uptake in streams, but previous research in Minnesota lakes suggests that an increase in labile $\mathrm{C}$ can increase bacterial uptake of $\mathrm{P}$ (Stets and Cotner 2008). In streams, seasonal increases in $P$ uptake (shortened uptake lengths) by stream biota have been observed when DOC concentrations are highest following leaf fall 
(Mulholland and Hill 1997) at Walker Branch in Tennessee and at Coweeta in North Carolina (Mulholland et al. 1985, D’Angelo and Webster 1991). However, among 17 Idaho streams no correlation was observed between DOC concentration and $\mathrm{PO}_{4}-\mathrm{P} \mathrm{V}_{\mathrm{f}}$ (Bechtold et al. 2012). Interestingly, the four sites (Big Pup, Hills, Little Garlic, Black) with significant SRP uptake all expressed similarities in DOM characteristics as identified from the PCA analysis, including greater FI, C5 (humic-like), and C2 (humiclike) than any of the other sites. Therefore $\mathrm{C}$ quality, rather than $\mathrm{C}$ quantity, may have a greater influence on whether $\mathrm{P}$ will be taken up in streams. Conclusions about the role of DOC concentration in SRP uptake from linear regression analysis alone are limited by the small number of streams with measureable SRP uptake $(n=4)$. However, the distinct DOM composition occurring at sites with significant SRP uptake compared with sites without detectable uptake as identified by PCA analysis provides further support that DOM character may be important in SRP uptake. While we sought to address how DOM composition may alter DOC uptake rates in our streams, undetectable DOC uptake at most sites in both years limited our ability to identify important drivers of DOC $\mathrm{V}_{\mathrm{f}}$.

Our study demonstrates that DOM composition can be an important driver of $\mathrm{NH}_{4}$ and SRP $V_{f}$, which is consistent with the concept of tight coupling between $\mathrm{C}$ and nutrient cycles in aquatic systems. In lake and marine ecosystems the addition of labile C sources can increase bacterial uptake of $\mathrm{N}$ or $\mathrm{P}$ by improving the ability of bacteria to compete with phytoplankton for inorganic nutrients (Joint et al. 2002, Hasegawa et al. 2005, Stets and Cotner 2008). Our methods did not identify whether autotrophic and/or heterotrophic communities utilized $\mathrm{N}$ or $\mathrm{P}$, but if altered community competition for $\mathrm{N}$ and $\mathrm{P}$ results in greater overall uptake in these rivers then our results suggest that 
variability in $\mathrm{V}_{\mathrm{f}}$ may due to the composition rather than the quantity of DOM. In contrast to previous studies that revealed that $\mathrm{N}$ uptake can increase as $\mathrm{C}$ concentrations increase (Bernhardt and Likens 2002, Johnson et al. 2009) we did not observe a relationship between DOC background concentrations and $\mathrm{NH}_{4} \mathrm{~V}_{\mathrm{f}}$, consistent with Bechtold et al. (2012). Rather, our results suggest that rivers with a greater contribution of terrestrial sources of DOC (i.e., lower FI) have greater $\mathrm{NH}_{4} \mathrm{~V}_{\mathrm{f}}$ than rivers with a greater contribution of microbial sources. A previous study has linked nutrient uptake to mineralization of organic matter and found that shorter nutrient uptake lengths in fall and winter were associated with greater abundance of course particulate organic matter abundance (Mulholland et al. 1985). Although FI values were tightly constrained across study sites, FI varied with watershed area and was a significant predictor of $\mathrm{NH}_{4} \mathrm{~V}_{\mathrm{f}}$, suggesting that even minor variations in FI may explain variability in nutrient uptake.

Our results suggest that variability in DOM composition was related to watershed size. The majority of the variability of DOM composition among rivers in our study was explained by the relative contributions of the six PARAFAC components to DOM. Three of the largest rivers had greater tryptophan-like fluorescence, an indicator of autochthonous-derived proteins, than smaller rivers. This may be explained by relatively open canopies or warmer water temperatures found in larger rivers, which can facilitate greater contributions from autochthonous sources (e.g. Hall 1971; Cummins 1974). Furthermore, the DOM molecules that fluoresce in this protein-derived region are biologically reactive (Lønborg et al. 2010, Guillamette and Del Giorgio 2011). Although tightly constrained, FI decreased with increasing watershed area across our study sites, suggesting that FI may be a function of watershed area and that a greater contribution of 
terrestrially-derived fulvic acids occurred in larger rivers. Wilson and Xenopoulos (2008) also found relationships between tightly constrained FI values (1.27 to 1.35 ) and land cover characteristics along an agricultural gradient in the Great Lakes region, where FI was negatively correlated with $\%$ wetland area and positively correlated with $\%$ cropland area. Although land cover characteristics were related to minor variations of FI within the watersheds in our study there was not a large gradient in land use among sites, which may suggest that watershed area is a proxy for another variable influencing variability in DOM character.

Variability in nutrient uptake among watersheds and years- $\mathrm{NH}_{4}$ is known to be highly bioreactive, and in our study sites we observed the greatest and most consistently detectable uptake velocities for $\mathrm{NH}_{4}$ relative to SRP and DOC. In Lake Superior tributaries both $\mathrm{N}$ and $\mathrm{P}$ can limit biomass of primary production (Allen and Hershey 1996; Wold and Hershey 1999), yet we generally observed rapid uptake of $\mathrm{NH}_{4}$ and not SRP. In contrast to $\mathrm{NH}_{4}$, which is predominately removed from the water column by autotrophic and heterotrophic organisms (Peterson et al. 2001), inorganic P uptake is regulated by physical and chemical processes as well as biological processes (Mulholland et al. 1990, Wither and Jarvie 2008). Multiple processes controlling uptake of inorganic P likely contributed to the variability in whether or how quickly SRP was taken up across sites and years. In 2012, but not 2013, SRP uptake velocities were greater than either $\mathrm{NH}_{4}$ or DOC. In southwestern Michigan streams labile DOC uptake (as acetate) was found to be greater than or equal to $\mathrm{NH}_{4}$ uptake (Johnson et al. 2009). At our sites, DOC uptake velocity never exceeded the greatest $\mathrm{NH}_{4}$ uptake velocities, yet when $\mathrm{DOC} \mathrm{V}_{\mathrm{f}}$ was 
detectable it was comparable to most $2013 \mathrm{NH}_{4}$ uptake velocities, and greater than all 2013 SRP uptake velocities.

Ammonium uptake was undetectable when $\mathrm{NH}_{4}$ background concentrations were elevated. Little Huron, where we did not detect $\mathrm{NH}_{4}$ uptake in either year, had the greatest background concentrations of $\mathrm{NH}_{4}$ of all sites $(20$ and $22 \mu \mathrm{g} \mathrm{L}-1)$ while background concentrations at the Salmon Trout rose from $8 \mu \mathrm{g} \mathrm{L}^{-1}$ in 2012, when $\mathrm{NH}_{4}$ uptake occurred, to $12 \mu \mathrm{g} \mathrm{L}^{-1}$ in 2013, when uptake was not detectable (Web appendix Table 1). Across all other sites $\mathrm{NH}_{4}$ background concentrations were below $7 \mu \mathrm{g} \mathrm{L} \mathrm{L}^{-1}$ and $\mathrm{NH}_{4}$ uptake was always detected. Undetectable uptake could be due to lower enrichment factors during the nutrient injections at these sites, which were targeted to increase background concentrations by 10 to $12 \mu \mathrm{g} \mathrm{L}^{-1}$ (2x increase at the Salmon Trout, $1.5 \mathrm{x}$ increase at the Little Huron) and resulted in actual enrichment factors ranging from 1.4 to 1.8 on dates when background concentrations were elevated. Alternatively, uptake of $\mathrm{NH}_{4}$ may be saturated on these dates such that there was not biological demand for the increased $\mathrm{NH}_{4}$ regardless of the enrichment factor. Regardless of the mechanism, the lack of $\mathrm{NH}_{4}$ uptake at these two sites appears to be affected by elevated background $\mathrm{NH}_{4}$ concentrations.

Ammonium and SRP uptake velocities in our study sites were similar to previous measurements across a variety of streams $\left(\mathrm{NH}_{4} \mathrm{~V}_{\mathrm{f}}=0\right.$ to $119 \mathrm{~mm} \mathrm{~min}^{-1}$, Tank et al. 2008; SRP Vf: 1.14 to $4.92 \mathrm{~mm} \mathrm{~min}^{-1}$, Bernot et al. 2006; $\mathrm{PO}_{4} \mathrm{~V}_{\mathrm{f}}$ : 0.9 to $11.6 \mathrm{~mm} \mathrm{~min}^{-1}$, Hall et al. 2002). Regionally, our study sites on the south shore of Lake Superior $\left(\mathrm{NH}_{4} \mathrm{~V}_{\mathrm{f}}: 0.9\right.$ $11.7 \mathrm{~mm} \mathrm{~min}^{-1}$; SRP $V_{\mathrm{f}}: 0.3-7.2 \mathrm{~mm} \mathrm{~min}^{-1}$ ) revealed lower uptake velocities than in some north shore streams $\left(\mathrm{NH}_{4} \mathrm{~V}_{\mathrm{f}}: 1.1-28.4 \mathrm{~mm} \mathrm{~min}^{-1} ; \mathrm{PO}_{4} \mathrm{~V}_{\mathrm{f}}: 0.75-15.7 \mathrm{~mm} \mathrm{~min}^{-1}\right.$ 
(Lehto and Hill 2013), but were similar with other measurements of inland Upper Peninsula streams ( $\mathrm{NH}_{4} \mathrm{~V}_{\mathrm{f}:}: 1.9$ to $7.6 \mathrm{~mm} \mathrm{~min}^{-1}$; $\mathrm{SRP} \mathrm{V}_{\mathrm{f}}: 1.1$ to $10.7 \mathrm{~mm} \mathrm{~min}^{-1}$ (Hoellein et al. 2007). DOC $\mathrm{V}_{\mathrm{f}}$ at our study sites (0.64 to $2.4 \mathrm{~mm} \mathrm{~min}^{-1}$ ) were also within the ranges of previous measurements of $\mathrm{C}$ uptake in streams (glucose $\mathrm{V}_{\mathrm{f}}: 1.4$ to $10.6 \mathrm{~mm} \mathrm{~min}^{-}$ ${ }^{1}$, Newbold et al. 2006; glucose $\mathrm{V}_{\mathrm{f}}$ : 0.6 to $4.5 \mathrm{~mm} \mathrm{~min}^{-1}$, Bechtold et al. 2012). It should be noted that in our study we measured total DOC rather than the specific form of carbon added (in this case, glucose), which may lead to underestimation of $\mathrm{V}_{\mathrm{f}}$ because a larger increase in background DOC concentration would be required to detect uptake (Mulholland et al. 2002, Johnson et al. 2009).

Export of solutes to downstream ecosystems - Ammonium was quickly taken up across most of our study streams, and likely cycled multiple times before being exported to Lake Superior. For most of our study sites, the distance $\mathrm{NH}_{4}$ traveled before being taken up was 30 to $98 \%$ shorter than the distance to Lake Superior and $\mathrm{NH}_{4}$ could be cycled up to 50 times in these streams before being exported. However, we did not account for the distance $\mathrm{NH}_{4}$ traveled in organic form after being taken up. Therefore, the total spiraling length could be much greater in these streams.

Our results suggest that these small to mid-size streams likely exported C and P directly to the downstream ecosystem, Lake Superior, without measureable uptake. For most of our study sites DOC uptake was either not detectable or DOC $S_{w}$ was greater than the distance to the downstream lake, suggesting that DOC may be exported to Lake Superior without being taken up. SRP uptake lengths indicate that SRP was only taken up before reaching Lake Superior in three of six streams in 2012 and two of eleven 
streams in 2013, and thus SRP likely is exported to downstream ecosystems without being taken up at the majority of our study sites. Although SRP concentrations are relatively low, riverine export of SRP could be important in fueling primary productivity in near shore regions of Lake Superior, where phytoplankton and bacterioplankton have been shown to be limited or co-limited by SRP (Sterner et al. 2004). Riverine export of $\mathrm{C}$ and $\mathrm{P}$ from the more than 1500 tributaries of Lake Superior (Coble et al., in preparation) may therefore supply important nutrient and energy sources to the nearshore region of the largest lake in the world, potentially fueling productivity in this oligotrophic downstream environment.

Conclusions-Our results provide strong support for the inclusion of DOM composition, and not only concentration, when deciphering and quantifying important relationships between uptake of $\mathrm{N}$ and $\mathrm{P}$ in aquatic ecosystems. Coupled cycling of $\mathrm{C}, \mathrm{N}$, and $\mathrm{P}$ occurs across aquatic ecosystems (e.g., marine, lake) and it is likely that DOM composition may also serve as important controls on biogeochemical cycling in those ecosystems. Recent studies of DOM variability across watersheds have paved the way for DOM composition to be integrated as a tool in aquatic biogeochemical studies. Furthermore, our results highlight the importance of stream-lake linkages in delivering essential nutrient and energy sources to downstream ecosystems.

\section{References}

Alexander, R. B., R. A. Smith, and G. E. Schwarz. 2000. Effect of stream channel size on the delivery of nitrogen to the Gulf of Mexico. Nature 403: 758-761 
Allen, N. S., and A.E. Hershey. 1996. Seasonal changes in chlorophyll a response to nutrient amendments in a north shore tributary of Lake Superior. J. N. Am. Benthol. Soc. 15: 170-178.

American Public Health Association [APHA]. 2005. Standard methods for the examination of water and wastewater. American Public Health Association.

Bechtold, H. A., A. M. Marcarelli, C. V. Baxter, and R. S. Inouye. 2012. Effects of N, $\mathrm{P}$, and organic carbon on stream biofilm nutrient limitation and uptake in a semiarid watershed. Limnol. Oceanogr. 57: 1544-1554, doi:

10.4319/lo.2012.57.5.1544

Bergey, E. A., and G. M. Getty. 2006. A review of methods for measuring the surface area of stream substrates. Hydrobiologia 556: 7-16.

Bernot, M. J., J. L. Tank, T. V. Royer, and M. B. David. 2006. Nutrient uptake in streams draining agricultural catchments of the midwestern United States. Freshwater Biology 51: 499-509.

Bernhardt, E. S., and G. E. Likens. 2002. Dissolved organic carbon enrichment alters nitrogen dynamics in a forest stream. . Ecology 83: 1689-1700.

Burnham, K. P., and D.R. Anderson. 2002. Model selection and multimodel inference: a practical information-theoretic approach. Second edition. Spring Science Business Media, New York, New York, USA

Coble, A. A., A. M. Marcarelli, and E. S. Kane. In review. Nutrient limitation of dissolved organic carbon mineralization in a Lake Superior tributary, J. Gt. Lakes Res. 
Coble, A. A., A. M. Marcarelli, E. S. Kane, R. S. Stottlemyer, D. Toczydlowski. In preparation. Seasonality, export, and biodegradability of dissolved oranic carbon in Lake Superior tributaries.

Cory, R. M., and D. M. Mcknight. 2005. Fluorescence spectroscopy reveals ubiquitous presence of oxidized and reduced quinones in dissolved organic matter. Environ. Sci. Technol. 39: 8142-8149.

Cummins, K. W. 1974. Structure and function of stream ecosystems. Bioscience 24: $631-641$

D'Angelo, D. J. and J. R. Webster. 1991. Phosphorus retention in streams draining pine and hardwood catchments in the southern Appalachian Mountains. Freshw. Biol. 26: $335-345$

Davis, J. C., and G. W. Minshall. 1999. Nitrogen and phosphorus uptake in two Idaho (USA) headwater wilderness streams. Oecologia 119: 247-255.

Frost, P. C., J. H. Larson, C. A. Johnston, K. C. Young, P. A. Maurice, G. A. Lamberti, and S. D. Bridgham, 2006 Landscape predictors of stream dissolved organic matter concentration and physicochemistry in a Lake Superior river watershed. Aquat. Sci. 68: 40-51.

Gergel, S. E., M. G. Turner, and T. K. Kratz. 1999. Dissolved organic carbon as an indicator of the scale of watershed influence on lakes and rivers. Ecol. Appl. 9: $1377-1390$.

Guillamete F., P. A. Del Giorgio. 2011. Reconstructing the various facets of dissolved organic carbon bioavailability in freshwater ecosystems. Limnol. .Oceanogr. 56: $734-748$ 
Hasegawa, T., H. Fukuda, and I. Koike. 2005. Effects of gluatmate and glucose on N cycling and the marine plankton community. Aquat. Microb. Ecol. 41: 125-130.

Hall, C. A. S. 1979. Migration and metabolism in a temperate stream ecosystem.

Ecology 53: 585-604

Hall, R. O., E. S. Bernhardt, and G. E. Likens. 2002. Relating nutrient uptake with transient storage in forested mountain streams. Limnol. .Oceanogr. 47: 255-265.

Hall, R. O., and J. L. Tank. 2003. Ecosystem metabolism controls nitrogen uptake in streams in Grand Teton National Park, Wyoming. Limnol. Oceanogr. 48: 11201128.

Hoellein, T. J., J. L. Tank, E. J. Rosi-Marshall, S. A. Entrekin, and G. A. Lamberti. 2007. Controls on spatial and temporal variation of nutrient uptake in three Michigan headwater streams. Limnol. Oceanogr. 52: 1964-1977.

Holmes, R. M., A. Aminot, R. Kérouel, B. A. Hooker, and B. J. Peterson. 1999. A simple and precise method for measuring ammonium in marine and freshwater ecosystems. Can. J. Fish. Aquat. Sci. 56: 1801-1808.

Johnson, L. T., J. L. Tank, and C. P. Arango. 2009. The effect of land use on dissovled organic carbon and nitrogen uptake in streams. Freshw. Biol. 54: 2335-2350.

Joint, I., P. Henriksen, G. A. Fonnes, D. Bourne, T. F. Thingstad, and B. Riemann. 2002. Competition for inorganic nutrients between phytoplankton and bacterioplankton in nutrient manipulated mesocosms. Aquat. Microb. Ecol. 29: 145-459.

Kothawala, D. N., C. A. Stedmon, R. A. Müller, G. A. Weyhenmeyer, S. J. Köhler, and L. J. Tranvik. 2014. Controls of dissolved organic matter quality: evidence from 
a large-scale boreal lake survey. Glob. Chang. Biol. 20: 1101-1114, doi:

$10.1111 / \mathrm{gcb} .12488$

Larson, J. H., P. C. Frost, M. A. Xenopoulos, C. J. Williams, A. M. Morales-Williams, J. M. Vallazza, J. C. Nelson, and W. B. Richardson. 2014. Relationships between land cover and dissolved organic matter change along the river to lake transition. Ecosystems 17: 1413-1425.

Lehto, L. L., and B. H. Hill. 2013. The effect of catchment urbanization on nutrient uptake and biofilm enzyme activity in Lake Superior (USA) tributary streams. Hydrobiologia 713: 35-51.

Lønborg, C., X. A. Alvarez-Salgado, K. Davidson, S. Martinez-Garcia, E. Teira. 2010. Assessing the microbial bioavailability and degradation rate constants of dissolved organic matter by fluorescence spectroscopy in the coastal upwelling system of the Ria de Vigo. Mar. Chem. 119: 121-129.

Maranger, R., and M. J. Pullen, 2003. Elemental complexation by dissolved organic matter in lakes: implications for Fe speciation and the bioavailability of Fe and P. p. 186-214. In S. E. Findlay and R. L. Sinsabaugh [eds.], Aquatic ecosystems interactivity of dissolved organic matter. Academic Press.

Marti, E., J. Aumatell, L. Gode, M. Poch, and F. Sabater. 2004. Nutrient retention efficiency in streams receiving inputs from wastewater treatment plants. J. Environ. Qual. 33: 285- 293.

McKnight, D.M., E. W. Boyer, P. K. Westerhoff, P. T. Doran, T. Kulbe, T., and D. T. Anderson. 2001. Spectrofluorometric characterization of dissolved organic matter 
for indication of precursor organic material and aromaticity. Limnol. Oceanogr. 46: 38-48, doi:10.4319/1o.2001.46.1.0038

McKnight, D. M., E. Hood, and L. Klapper. 2003. Trace organic moieties of dissolved organic material in natural waters, p. 71-96. In: S. E. Findlay, and R. L.

Sinsabaugh [eds.], Aquatic ecosytems interactivity of dissolved organic matter. Academic Press.

Michigan Department of Environmental Quality (MDEQ) Geologic Survey Division. 1987. Template - Bedrock Geology. MDEQ, Lansing, MI

Mulholland P. J. 1992. Regulation of nutrient concentrations in a temperate forest stream: roles of upland, riparian, and instream processes. Limnol. Oceanogr. 37: 15121526.

Mulholland, P. J., A. D. Steinman, and J. W. Elwood. 1990. Measurement of phosphorus uptake length in streams: comparison of radiotracer and stable PO4 releases. Can. J. Fish. Aquat. Sci. 47: 2351-2357.

Mulholland, P. J., J. D. Newbold, J. W. Elwood, and J. W. Webster. 1985. Phosphorus spiralling in a woodland stream: seasonal variations. Ecology 66: 1012-1023.

Mulholland P. J., J. L. Tank, J. R. Webster, W. B. Bowden, W. K. Dodds, S. V. Gregory, N. B. Grimm, S. K. Hamilton, S. L. Johnson, E. Marti, W. H. McDowell, J. L. Merriam, J. L. Meyer, B. J. Peterson, H. M. Valett, and W. M. Wollheim. 2002. Can uptake length in streams be determined by nutrient addition experiments? Results from an interbiome comparison study. J. N. Am. Benthol. Soc. 21: 544560. 
Mulholland, P. J., and W. R. Hill. 1997. Seasonal patterns in streamwater nutrient and dissolved organic carbon concentrations: separating catchment flow path and instream effects. Water Resour. Res. 33: 1297-1306.

Newbold J. D., J. W. Elwood, M. S. Schulze, R. W. Stark, and J. C. Barmeier. 1983. Continuous ammonium enrichment of a woodland stream: uptake kinetics, leaf decomposition, and nitrification. Freshw. Biol. 13: 193-204

Newbold J. D., T. L. Bott, L. A. Kaplan, C. L. Dow, J. K. Jackson, A. K. Aufdenkampe, L. A. Martin, D. J. Van Horn, and A. A. De Long. 2006. Uptake of nutrients and organic C in streams in New York City drinking-water-supply watersheds. J. N. Am. Benthol. Soc. 25: 998-1017.

Nusch, E. A. 1980. Comparison of different methods for chlorophyll and phaeopigment determination. Archiv für Hydrobiologie-Beiheft 14: 14-36.

Olefeldt D., M. R. Teretsky, and C. Blodau. 2013. Altered composition and microbial versus UV-mediated degradation of dissolved organic matter in boreal soils following wildfire. Ecosystems 16: 1396-1412.

Peterson B. J., W. M. Wollheim, P. J. Mulholland, J. R. Webster, J. L. Meyer, J. L. Tank, E. Marti, W. B. Bowden, H. M. Valett, A. E. Hershey, W. H. McDowell, W. K. Dodds, S. K. Hamilton, S. Gregory, D. D. Morrall. 2001. Control of nitrogen export from watersheds by headwater streams. Science 292:86-90.

Prairie, Y. T. 2008 Carbocentric limnology: looking back, looking forward. Can. J. Fish. Aquat. Sci. 65: 543-548. 
Sabater, F., A. Butturini, E. Martí, I. Muñoz, A. Romaní, J. Wray, and S. Sabater. 2000. Effects of riparian vegetation removal on nutrient retention in a Mediterranean stream. J. N. Am. Benthol. Soc. 19: 609-620.

Sobczak,W. V., Findlay, S., Dye, S., 2003. Relationships between DOC bioavailability and nitrate removal in an upland stream: an experimental approach.

Biogeochemistry 62: 309-327.

Stedmon, C.A., and R. Bro. 2008 Characterizing dissolved organic matter fluorescence with parallel factor analysis: a tutorial. Limnol. Oceanogr.-Meth.. 6: 572-579, doi:10.4319/lom.2008.6.572

Stedmon, C. A., and S. Markager. 2005a. Resolving the variability in dissolved organic matter fluorescence in a temperate estuary and its catchment using PARAFAC analysis. Limnol. Oceanogr. 50: 686-697.

Stedmon, C. A., and S. Markager. 2005b. Tracing the production and degradation of autochthonous fractions of dissolved organic matter by fluorescence analysis. Limnol. Oceanogr. 50: 1415-1426.

Stedmon, C. A., S. Markager, and R. Bro. 2003 Tracing dissolved organic matter in aquatic environments using a new approach to fluorescence spectroscopy. Mar. Chem. 82: 239-254, doi:10.1016/S0304-4203(03)00072-0

Steinman, A. D., G. A. Lamberti, and P. R. Leavitt. 2007. Biomass and pigments of benthic algae p. 357-379. In F. R. Hauer and G. A. Lamberti [eds.], Methods of Stream Ecology, $2^{\text {nd }}$ ed. Academic Press. 
Sterner, R. W., T. M. Smutka, R. M. L. McKay, Q. Xiaoming, E. T. Brown, and R. M. Sherrell. 2004. Phosphorus and trace metal limitation of algae and bacteria in Lake Superior. Limnol. Oceanogr. 49: 495-507.

Stets, E. G. and J. B. Cotner. 2008. The influence of dissolved organic carbon on bacterial phosphorus uptake and bacteria-phytoplankton dynamics in two Minnesota lakes. Limnol. Oceanogr. 53: 137-147.

Stottlemyer, R., 1997. Streamwater chemistry in watersheds receiving different atmospheric inputs of $\mathrm{H}^{+}, \mathrm{NH}_{4}{ }^{+}, \mathrm{NO}_{3}{ }^{-}$, and $\mathrm{SO}_{4}{ }^{2-}$. J.Am. Water Resour. As. 33: $767-780$.

Stottlemyer, R., and D. Toczydlowski. 2006. Effect of reduced winter precipitation and increased temperature on watershed solute flux. Biogeochemistry 77: 409-440, doi $10.1007 / \mathrm{s} 10533-005-1810-1$

Stream Solute Workshop. 1990. Concepts and methods for assessing solute dynamics in stream ecosystems. J. N. Am. Benthol. Soc. 9: 95-119.

Tank, J. L., E. J. Rosi-Marshall, M. A. Baker, and R. O. Hall. 2008. Are rivers just big streams? A pulse method to quantify nitrogen demand in a large river. Ecology 89: $2935-2945$.

Taylor, B. W. and others 2007. Improving the fluorometric ammonium method: matrix effects, background fluorescence, and standard additions. J. N. Am. Benthol. Soc. 26: $167-177$

Thurman, M., ed. Organic geochemistry of natural waters. Vol. 2. Springer, 1985. 
Webster, K. E., P. A. Soranno, K. S. Cheruvelil, M. T. Bremigan, J. A. Downing, P. D. Vaux, T. R. Asplund, L. C. Bacon, and J. Connor. 2008. An empirical evaluation of the nutrient-color paradigm for lakes. Limnol. Oceanogr. 53: 1137-1148.

Weishaar, J. L., G. R. Aiken, B. A. Bergamaschi, M. S. Fram, R. Fujii, and K. Mopper. 2003. Evaluation of specific ultraviolet absorbance as an indicator of the chemical composition and reactivity of dissolved organic carbon. Environ. Sci. Technol. 37: 4702-4708.

Wilson, H. F., and M. A. Xenopoulos. 2008. Effects of agricultural land use on the composition of fluvial dissolved organic matter. Nat. Geosci. 2: 37-41, doi: $10.1038 /$ ngeo391

Withers, P. J. A., and H. P. Jarvie. 2008. Delivery and cycling of phosphorus in rivers: a review. Sci. Total Environ. 400: 379-395.

Wold, A. P., and A.E. Hershey. 1999. Spatial and temporal variability of nutrient limitation in 6 north shore tributaries to Lake Superior. J. N. Am. Benthol. Soc.18: 2-14.

Yamashita, Y., B. D. Kloeppel, J. Knoepp, G. L. Zausen, and R. Jaffe'. 2011. Effects of watershed history on dissolved organic matter characteristics in headwater streams. Ecosystems 14: 110-1122, doi: 10.1007/s10021-011-9469-z 


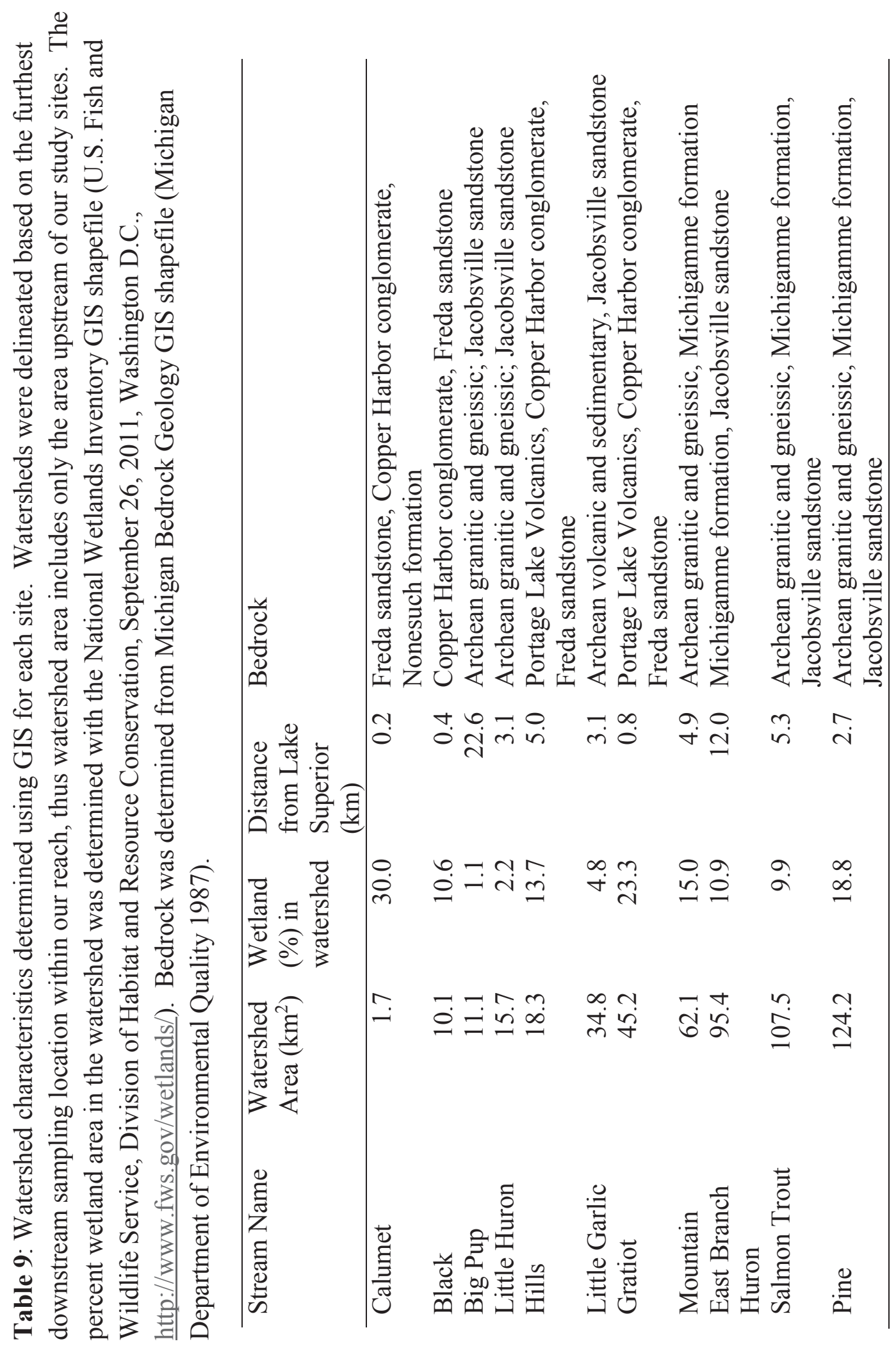




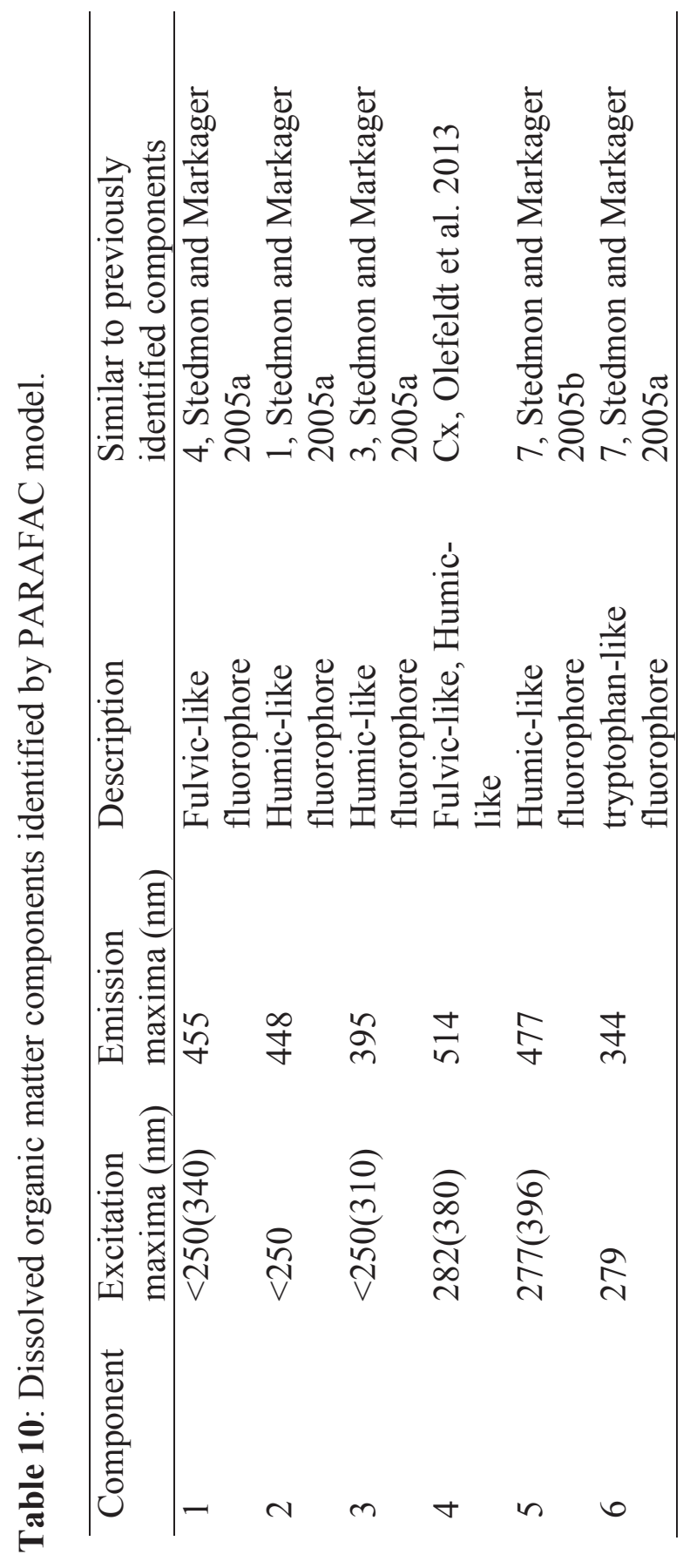


Table 11: Loadings for the four principal components identified in the PCA model of DOM composition and concentration. Percent variability explained by each component listed in parentheses.

\begin{tabular}{lrrrr}
\hline Variable & \multicolumn{1}{l}{$\begin{array}{l}\text { PC 1 } \\
(63.4 \%)\end{array}$} & $\begin{array}{l}\text { PC2 } \\
(18.5 \%)\end{array}$ & \multicolumn{1}{l}{$\begin{array}{l}\text { PC3 } \\
(9 \%)\end{array}$} & \multicolumn{1}{l}{$\begin{array}{l}\text { PC4 } \\
(6 \%)\end{array}$} \\
\hline SUVA & 0.14 & -0.19 & -0.14 & 0.16 \\
DOC & 0.17 & -0.20 & 0.18 & -0.01 \\
FI & 0.08 & 0.26 & 0.10 & 0.13 \\
\%C1 & 0.31 & -0.05 & 0.03 & 0.04 \\
\%C2 & -0.30 & 0.06 & -0.06 & 0.01 \\
\%C3 & -0.27 & -0.08 & 0.13 & 0.05 \\
\%C4 & 0.29 & 0.01 & -0.04 & -0.11 \\
\%C5 & 0.30 & 0.10 & -0.02 & -0.01 \\
\%C6 & -0.29 & -0.06 & -0.03 & -0.02 \\
\hline
\end{tabular}


Table 12: Multiple regression model results of uptake velocity of ammonium $\left(\mathrm{NH}_{4}\right)$ and soluble reactive phosphate (SRP) as response variables and a variety of biological, chemical, and physical variables as predictors. Only sites with significant uptake were included in the models $\left(\mathrm{NH}_{4} \mathrm{~V}_{\mathrm{f}}\right.$ model, $\mathrm{n}=9$; $\mathrm{SRP} \mathrm{V}_{\mathrm{f}}$ model, $\left.\mathrm{n}=4\right)$. We used AIC to identify and select the most important predictors. We selected models with AIC lower than two units below that of the Null model of complete randomness, and $>0.01$ Akaike weight (Burnham and Anderson 2002). One significant single predictor model is shown here for comparison but this model was not considered for Akaike weight calculations because $\triangle \mathrm{AIC}$ was greater than 2 units from the best model. All of the models are based on the following covariates, except for the NULL model which assumes a constant rate: $\mathrm{DOC}=$ dissolved organic carbon concentration $\left(\mathrm{mg} \mathrm{L}^{-1}\right), \mathrm{FI}=$ fluorescence index, $\mathrm{NH}_{4}=$ ammonium concentration $\left(\mu \mathrm{g} \mathrm{L}^{-1}\right)$ CanopyCover = canopy cover $(\%)$,

\begin{tabular}{lllllll}
\hline Response & Model & AIC & p-value & $\mathrm{R}^{2}$ adj & w & $\Delta$ AIC \\
\hline $\mathrm{NH}_{4}$ Vf & $\log \mathrm{FI}+\mathrm{NH}_{4}+$ Canopy & 45.23 & 0.03 & 0.69 & 0.58 & 0 \\
& Cover & & & & & \\
& $\log \mathrm{FI}+\mathrm{NH}_{4}$ & 45.84 & 0.02 & 0.65 & 0.42 & 0.61 \\
& $\log \mathrm{FI}$ & 49.50 & 0.03 & 0.44 & & 4.26 \\
& Null & 53.86 & - & - & - & 8.63 \\
\hline SRP Vf & $\log$ DOC & -1.48 & 0.03 & 0.90 & 1 & 0 \\
& Null & 7.24 & & & & 8.72 \\
\hline
\end{tabular}




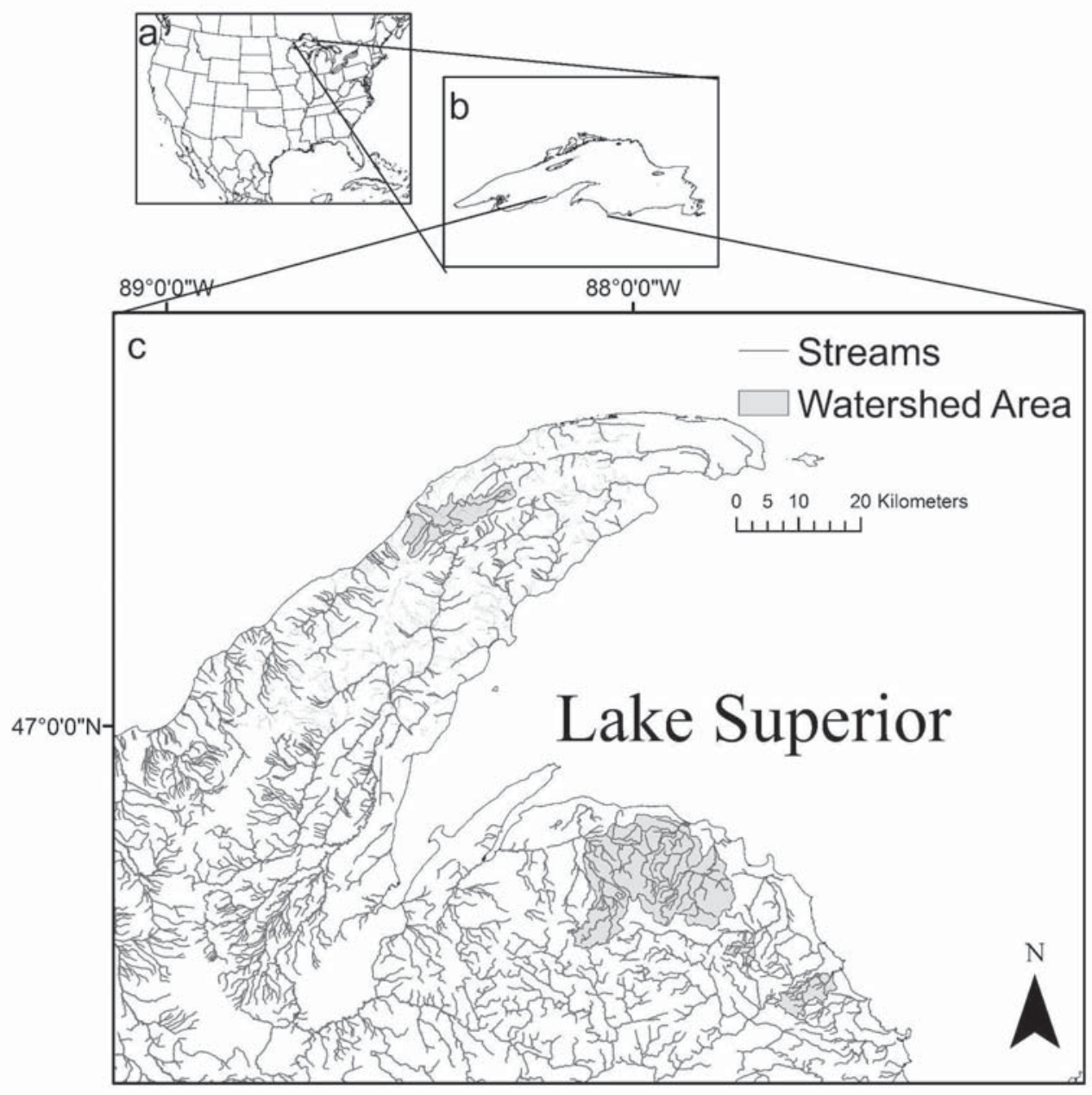

Figure 11. a. Location of Laurentian Great Lakes watersheds shown in relation to the contiguous United States of America. b. Location of Lake Superior watersheds in relation to the Laurentian Great Lakes. c. Location of study sites and their delineated watersheds. 


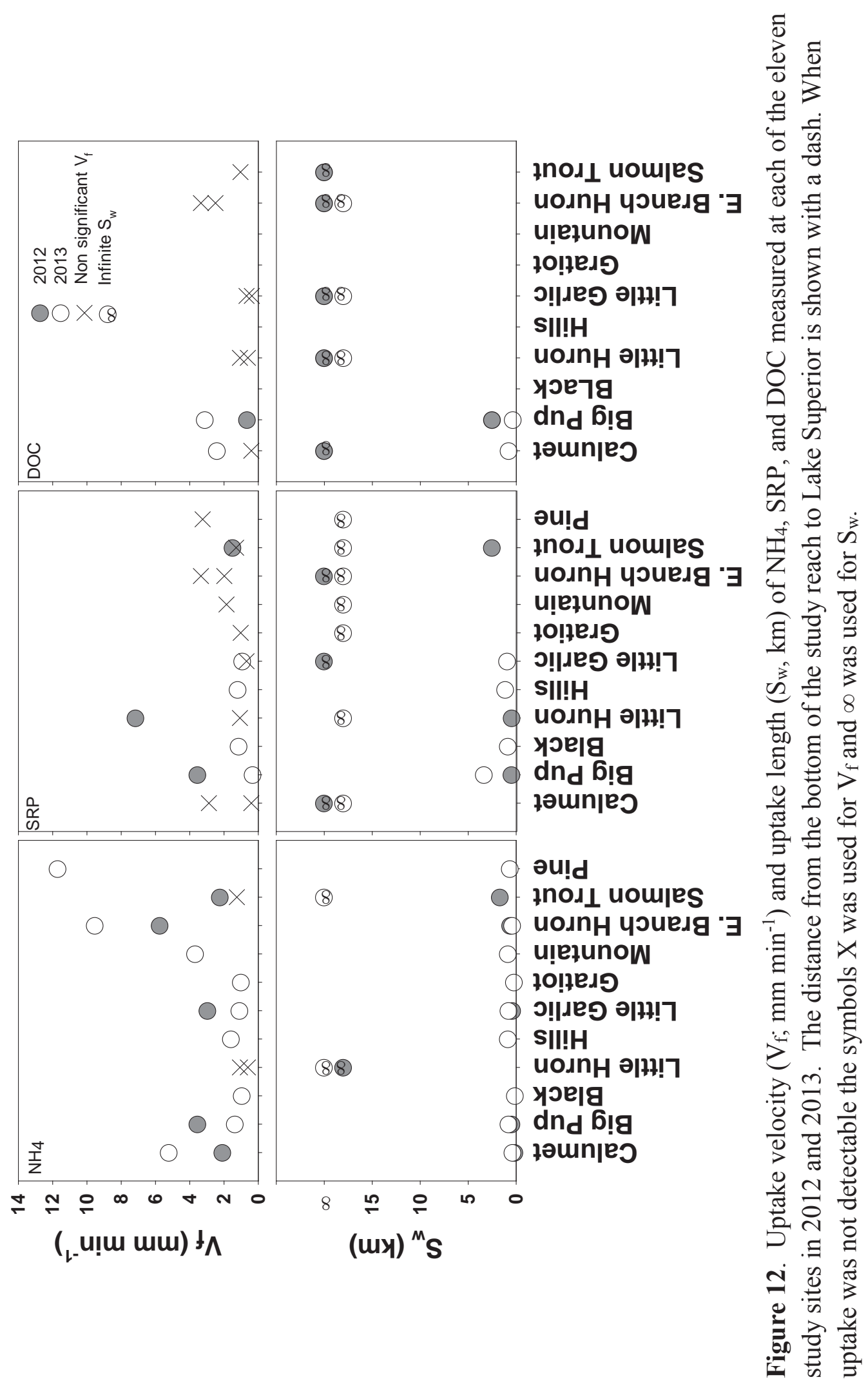




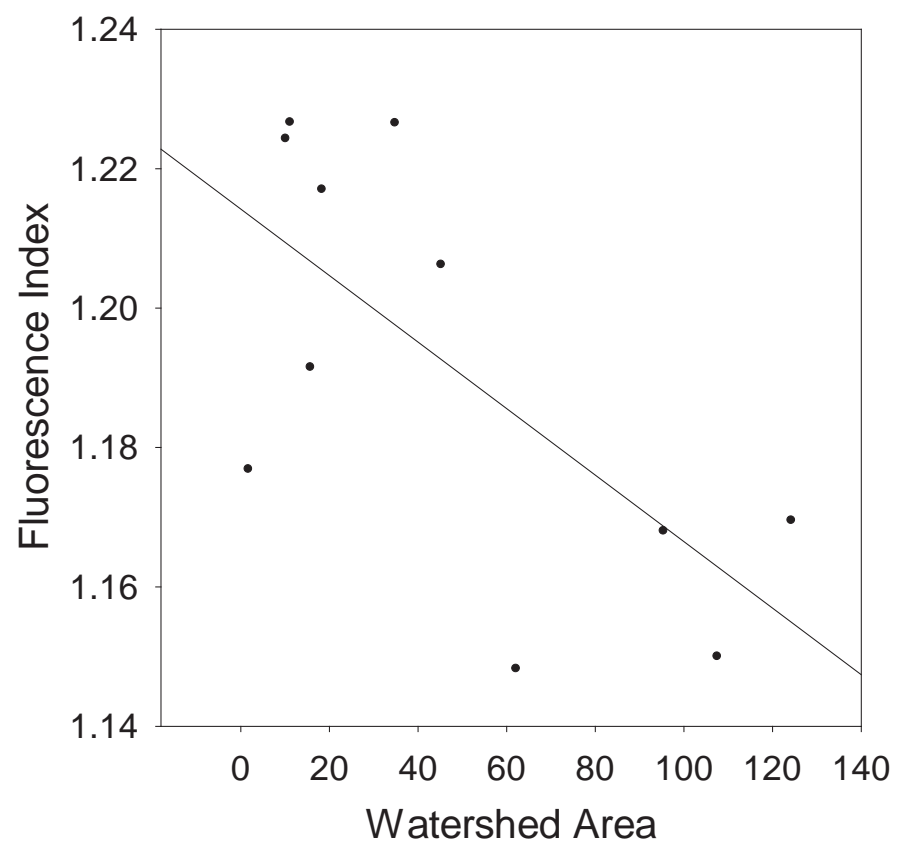

Figure 13. Watershed Area was a significant predictor of Fluorescence Index (FI) across the eleven study sites sampled in $2013\left(\mathrm{~F}_{(1,9)}=7.788, \mathrm{p}=0.02103, \mathrm{r}^{2}{ }_{\text {adj }}=0.4043\right)$. 


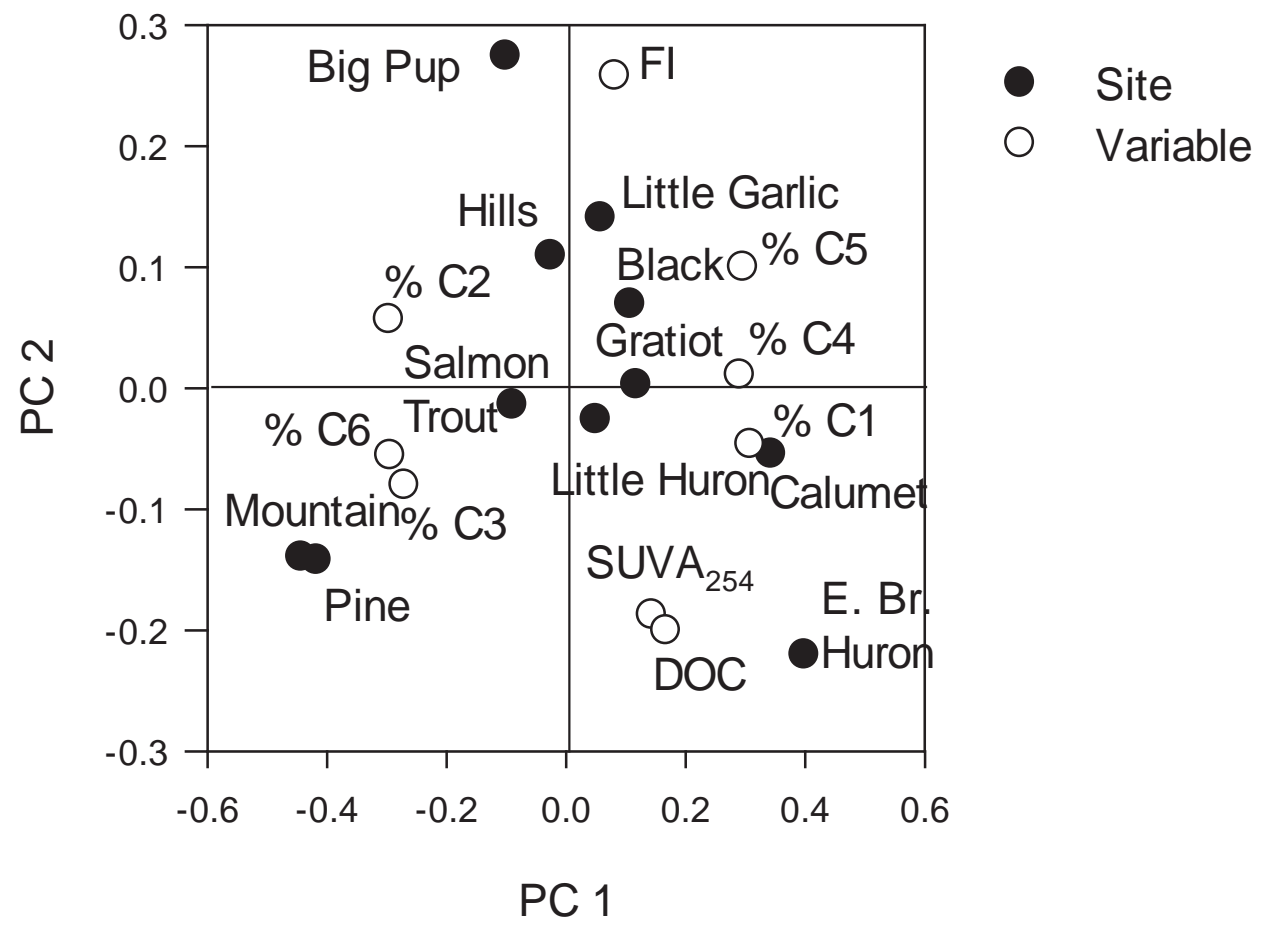

Figure 14. Principal components analysis loading plot of the first two principal components displaying DOC characteristics and sites. 

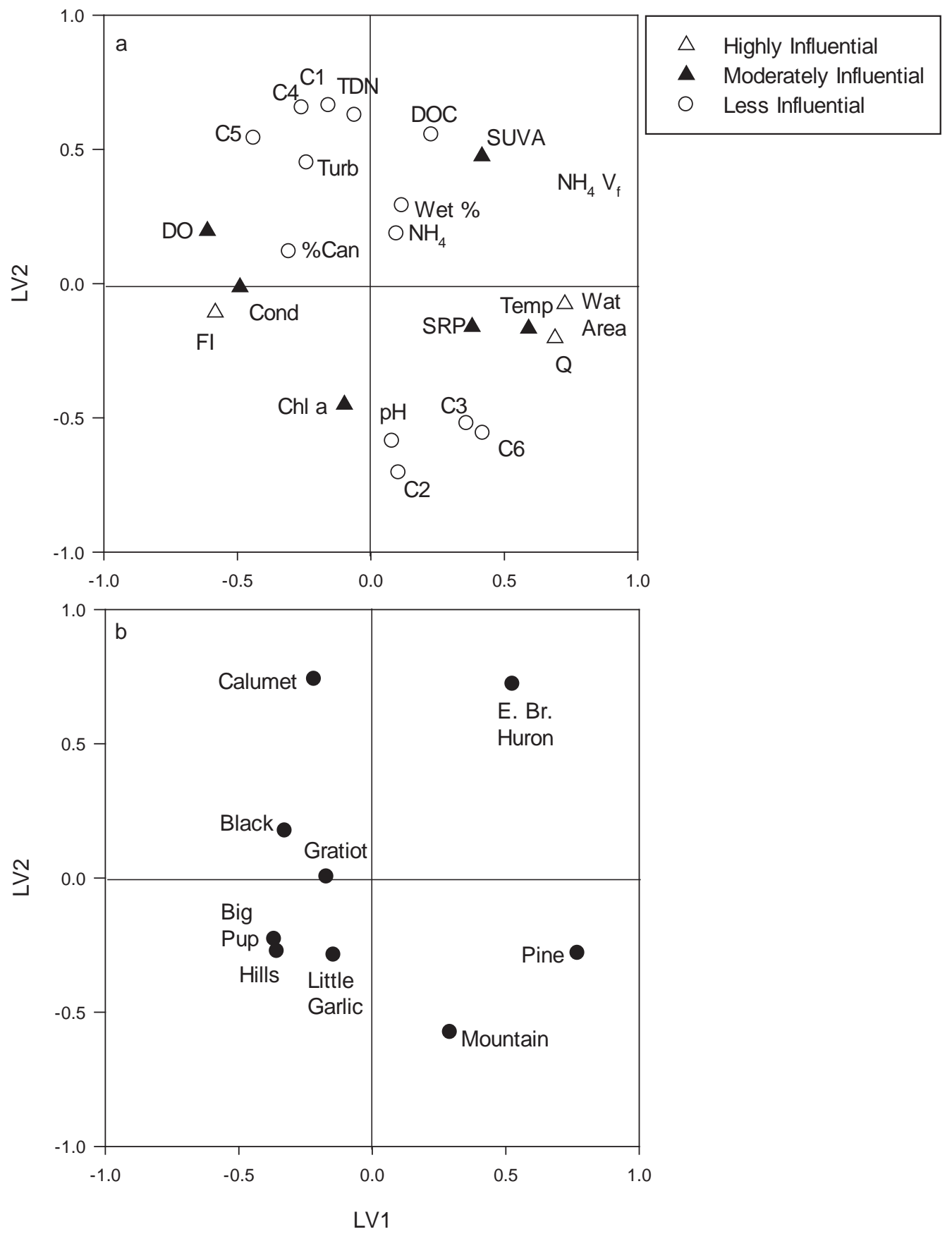

Figure 15. Partial least squares loading plot predicting the variability of ammonium uptake velocity $\left(\mathrm{NH}_{4} \mathrm{~V}_{\text {f; }}\right.$; response variable) with biological, chemical, and physical characteristics as predictors (predictor variable): a) all predictor and response variables b) sites only. Little Huron and the Salmon Trout River were excluded from analysis because $\mathrm{NH}_{4} \mathrm{~V}_{\mathrm{f}}$ was undetectable. 


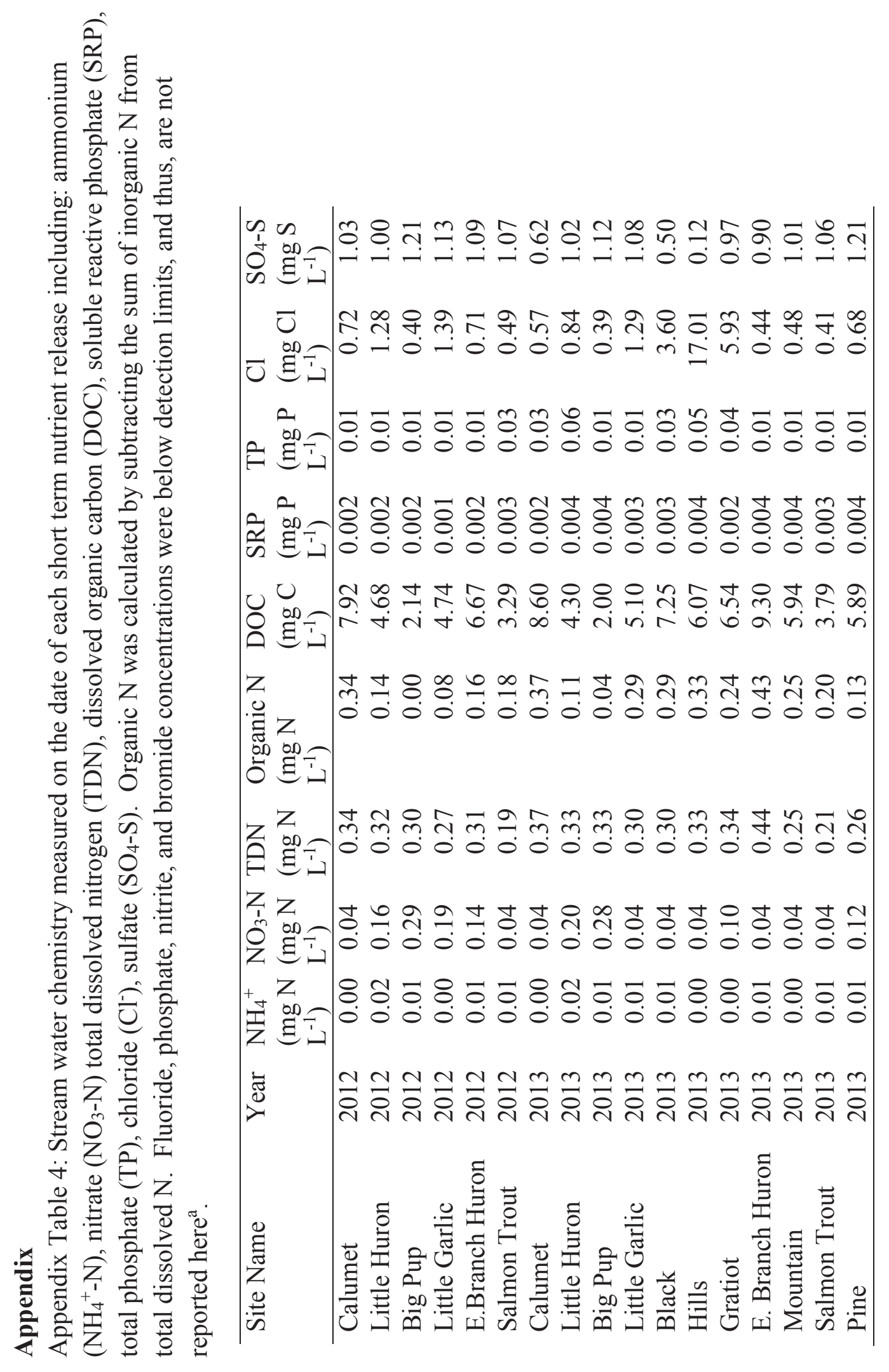




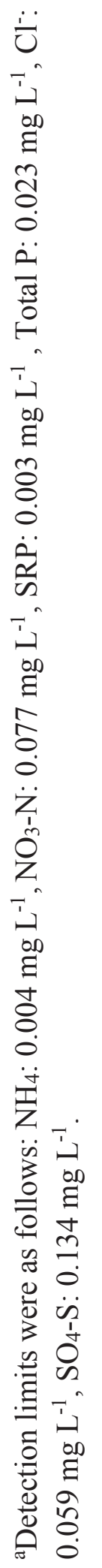




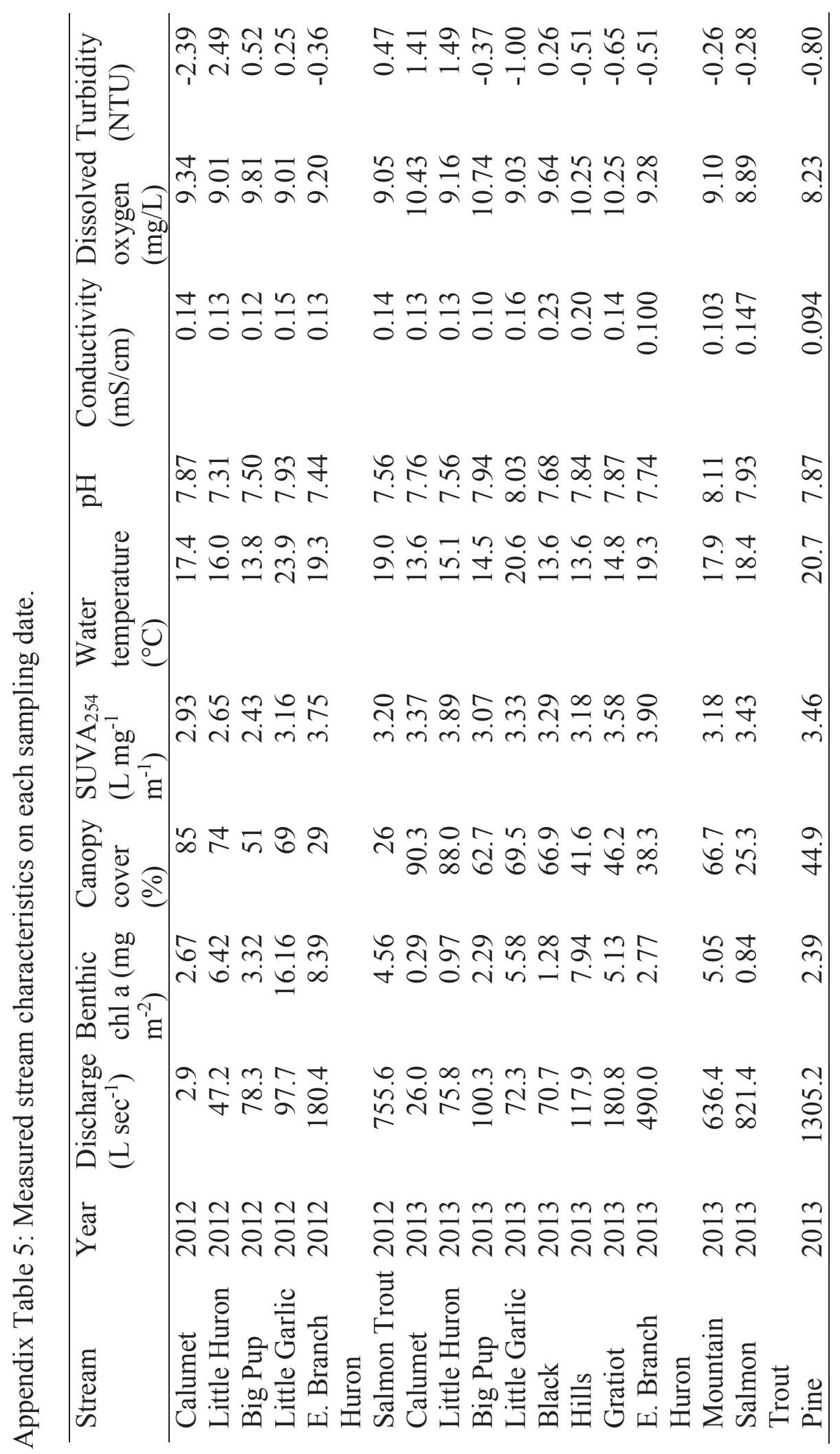


.

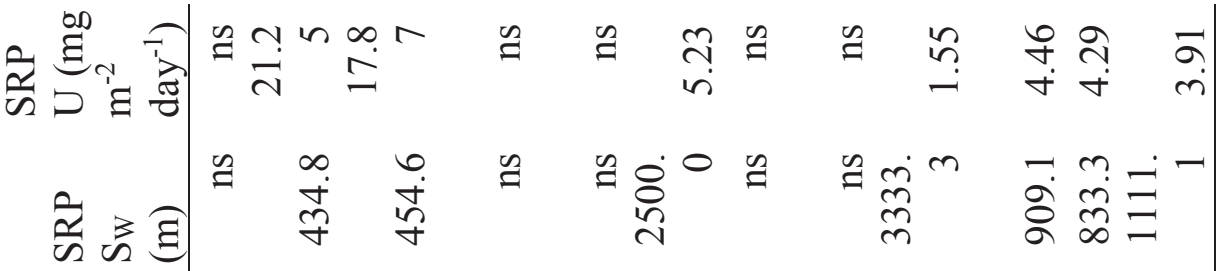

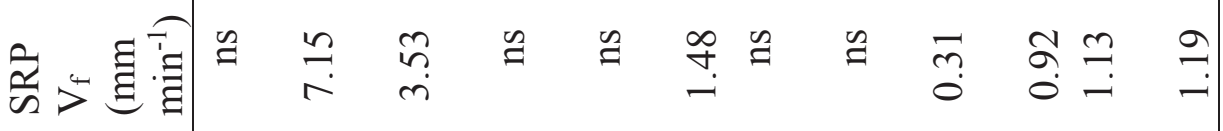

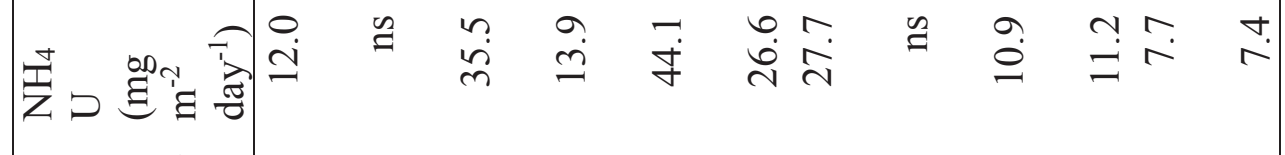

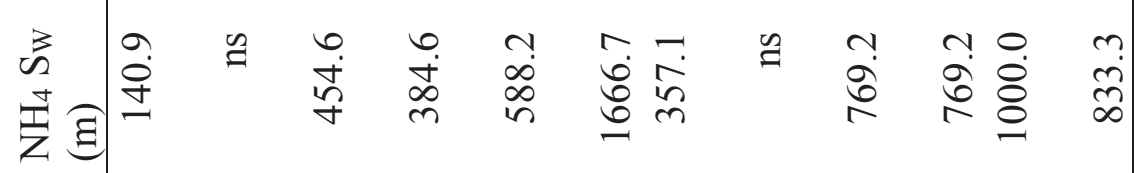

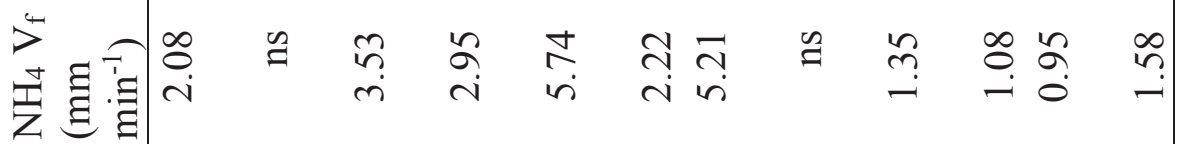
ฉ

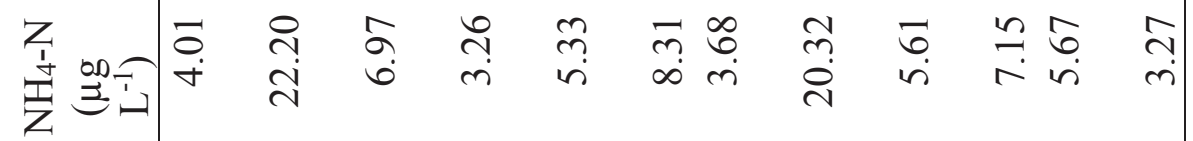

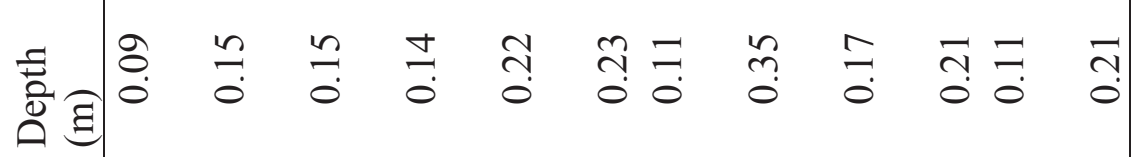

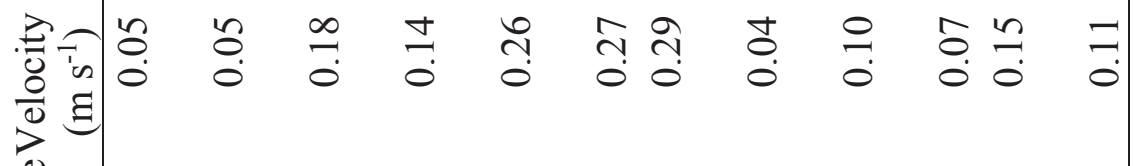




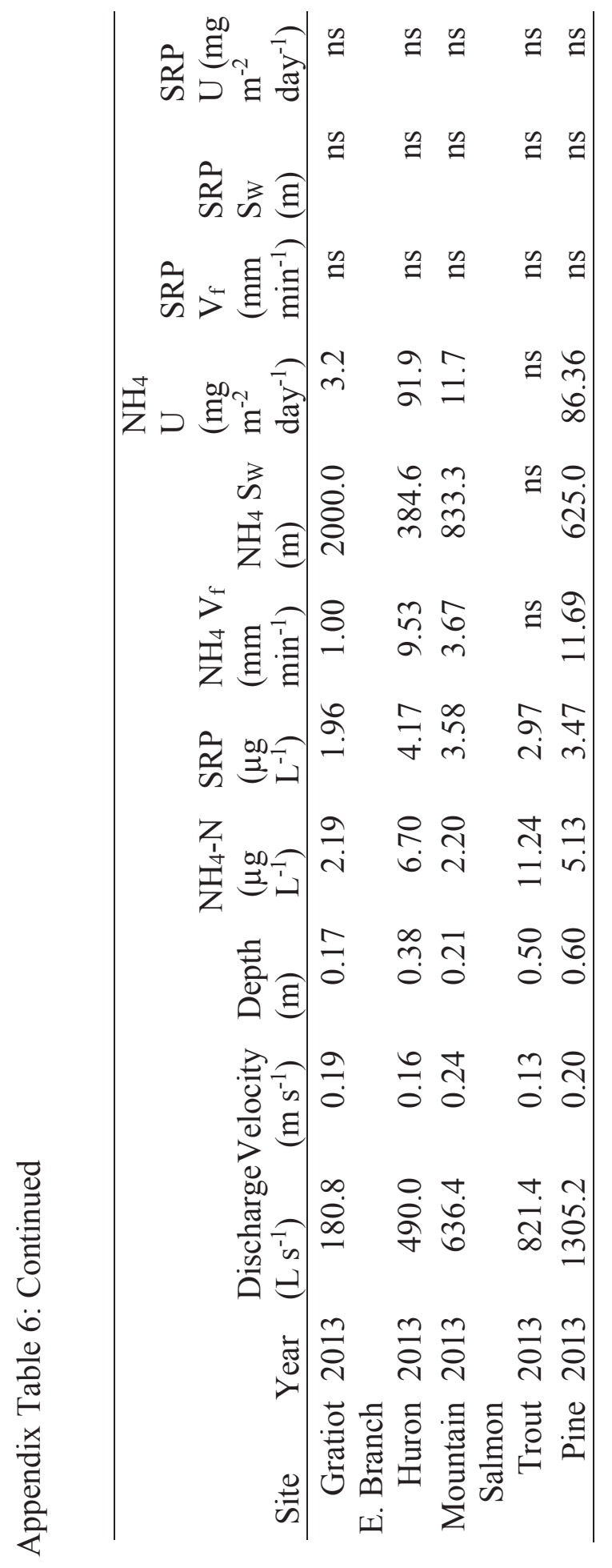




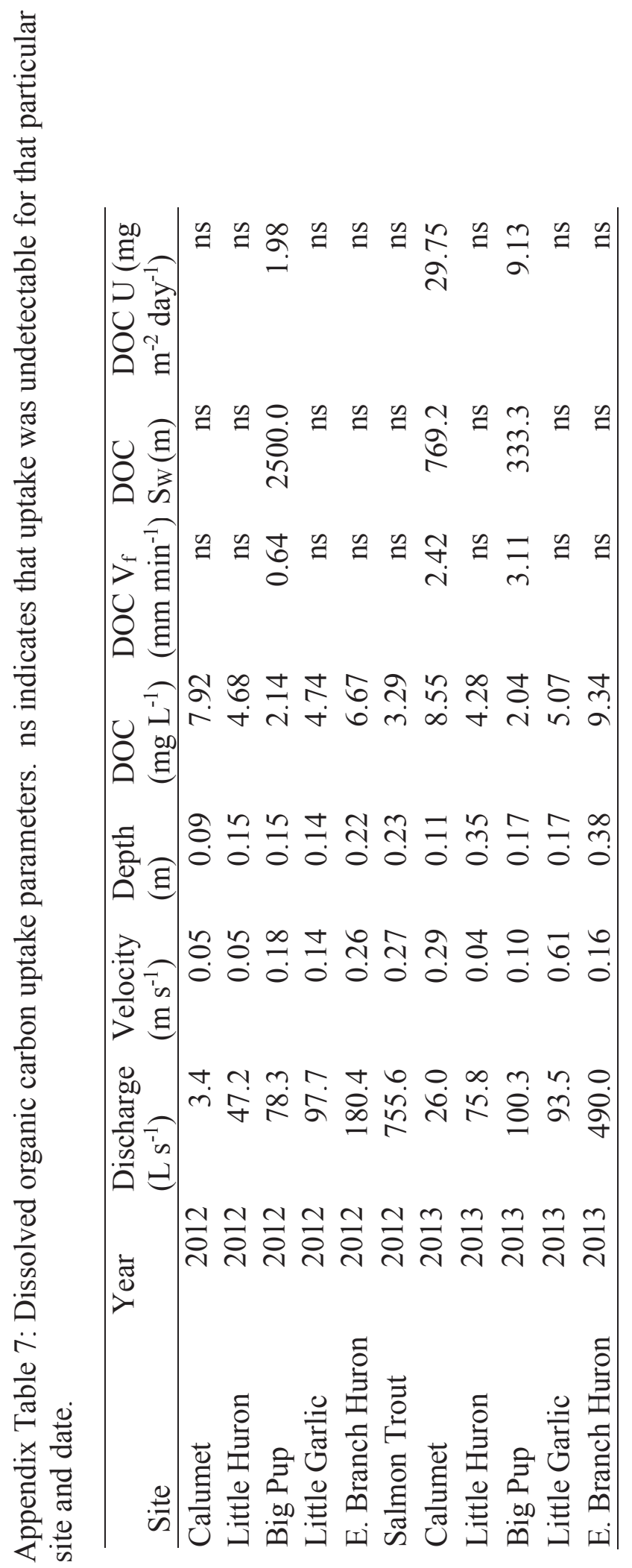




\section{Chapter 5: Year-round measurements of nutrient uptake in a snowmelt-driven}

headwater stream ${ }^{\mathrm{a}}$

Running Head: Temporal variability of nutrient uptake

Title

Year-round measurements of nutrient uptake in a snowmelt-driven headwater stream

Authors

Ashley A. Coble*1, Amy M. Marcarelli ${ }^{1}$, Evan S. Kane ${ }^{2,3}$

*corresponding author, Email: aacoble@mtu.edu, Phone: 620200 7696, Fax: 906487

3167

${ }^{1}$ Department of Biological Sciences, Michigan Technological University, 1400 Townsend

Drive, Houghton, Michigan 49931

${ }^{2}$ School of Forest Resources and Environmental Science, Michigan Technological

University, Houghton, Michigan 49931

${ }^{3}$ U.S. Forest Service, Northern Research Station, 410 MacInnes; Houghton, Michigan 49931

${ }^{\text {a }}$ This chapter was formatted to be submitted as a report to Ecology 
Abstract

It is uncertain how climate change may affect export of essential nutrients to downstream ecosystems in regions that host substantial winter snowpack because nutrient uptake is rarely quantified in snow and ice covered streams and rivers. To evaluate how nutrient uptake varied year-round in relation to temporal variability in biofilm standing crop, light availability, nutrient and organic matter availability, and hydrology we measured nutrient uptake of ammonium $\left(\mathrm{NH}_{4}\right)$ and soluble reactive phosphate (SRP) at 2 to 4 week intervals for three years and dissolved organic carbon (DOC) for two years. The greatest uptake velocities $\left(\mathrm{V}_{\mathrm{f}}\right)$ were observed in spring and fall for $\mathrm{NH}_{4}$, spring for $\mathrm{SRP}$, and fall for DOC. Winter $\mathrm{NH}_{4} \mathrm{~V}_{\mathrm{f}}$ were similar to and $\mathrm{SRP} \mathrm{V}_{\mathrm{f}}$, were greater than summer baseflow measurements, but DOC $\mathrm{V}_{\mathrm{f}}$ was undetectable in winter. Using partial least squares and multiple regression analysis we found that light availability, benthic chlorophyll a, benthic ash-free dry mass, solute concentrations, and $\mathrm{pH}$ collectively were important predictors of $\mathrm{NH}_{4} \mathrm{~V}_{\mathrm{f}}$. These results suggest that any future alteration to the timing of these key chemical and biological variables may alter nutrient export to downstream ecosystems. Furthermore, our results suggest that in-stream winter processing cannot be ignored.

Key Words: nutrient uptake, nitrogen, phosphorus, dissolved organic matter, headwater, seasonality, Michigan Upper Peninsula 


\section{Introduction}

Watershed mass-balance studies have historically regarded streams as a mechanism to deliver nutrients from watersheds, and ignored in-stream processing of nutrients (e.g., Vitousek and Reiners 1975, Goodale and Aber 2001). Yet, in-stream retention and transformation of nitrogen, phosphorus, and carbon controls nutrient and carbon export across a variety of geographic regions (Alexander et al. 2000, Peterson et al. 2001, Bernhardt et al. 2005, Withers and Jarvie 2008, Johnson et al. 2009, Bechtold et al. 2012). Assimilation by autotrophic and heterotrophic organisms is a dominant process responsible for the removal of inorganic nitrogen in headwater streams (Peterson et al. 2001). Inorganic P uptake is influenced by biological assimilation and by physical and chemical processes (Mulholland et al. 1990, Withers and Jarvie 2008). Therefore, variability in biological, physical and chemical parameters alters in-stream nutrient uptake, in-turn affecting export nutrients or carbon from the watershed to downstream ecosystems.

Stream nutrient processing can vary temporally (Mulholland et al. 1985, Hoellein et al. 2007, Roberts and Mulholland 2007; Hall et al. 2009) yet little is known about the factors that control seasonal variability in uptake rates due largely to a paucity of studies. The suite of variables that influence biotic activity in the stream (e.g., light availability, temperature, discharge, or nutrient inputs) vary seasonally, thus some combination of these environmental characteristics should influence seasonal variability in nutrient uptake. Measurements of nutrient uptake across seasons not typically sampled, such as winter and spring, can provide new insight into controls on stream nutrient uptake (e.g., Hoellein et al. 2007, Hall et al. 2009). Studies including winter or spring measurements 
have found the greatest uptake of phosphate $\left(\mathrm{PO}_{4}^{-}\right)$occurred in fall (Mulholland et al. 1985), high levels of $\mathrm{N}$ retention occurred during both snowmelt and baseflow conditions in an Idaho stream (Hall et al. 2009), and the greatest $\mathrm{N}$ uptake velocity was observed in spring in 4 Michigan streams (Hoellein et al. 2007).

Climate change is expected to alter hydrology throughout the United States (Groisman et al. 2004), and in northern temperate regions winter snowpack is likely to decrease with important potential consequences for biogeochemical cycling in streams. Changes in the intensity or quantity of freeze thaw cycles (Henry 2008) can alter concentrations of solutes entering streams (Mitchell et al. 1996, Watmough et al. 2004), hydrological flowpaths to streams (Stottlemyer and Toczdlowski 2006), and nutrient export from streams (Judd et al. 2011). Additionally, variability in the intensity or type of precipitation received could further alter delivery of nutrients or $\mathrm{C}$ inputs into streams (Groisman et al. 2004, Mortsch and Quinn 1996) potentially affecting in-stream nutrient uptake. However, before we can predict how stream biogeochemical cycling may respond to climate change we must first understand how in-stream nutrient cycling varies seasonally in response to major environmental drivers.

Few studies have examined in-stream processing of nutrients throughout the entire year, particularly in regions where snow represents a significant amount of the annual precipitation. Before we can begin to understand how climate change may affect nutrient cycling in the vast freshwater resources found in northern climates, it is necessary to identify how in-stream processing varies in streams across the full annual cycle including during snow/ice cover and spring runoff. To address this knowledge gap we measured in-stream nutrient uptake and environmental characteristics at 2-4 week 
intervals for three years in a headwater stream. We addressed the following research questions: 1) How does nutrient uptake of $\mathrm{N}, \mathrm{P}$, and $\mathrm{C}$ vary temporally in regions with snow-dominated hydrographs? 2) Does uptake of $\mathrm{N}, \mathrm{P}$, and $\mathrm{C}$ occur in winter when ice/snow cover often covers the stream? 3) Which physical and chemical drivers influence temporal variability in nutrient uptake? We hypothesized: that in-stream nutrient spiraling would vary seasonally, due to increased light availability and nutrient pulses contributed by snowmelt in spring and leaf litter in fall relative to winter and summer when light and nutrient inputs would be minimal.

\section{Study Area}

This research was conducted at Calumet watershed, a 1st order watershed (1.76 $\mathrm{km}^{2}$ ) located on the southern shore of Lake Superior near Calumet, Michigan. Mean annual precipitation at Calumet watershed is $80 \pm 20 \mathrm{~cm}$ (Stottlemyer and Toczydlowki 1996 ) with up to $50 \%$ occurring as snowfall (Stottlemyer 1997). Overstory vegetation within the watershed is primarily comprised of: sugar maple (Acer saccharum Marsh) and white birch (Betula papyrifera March). There has been ongoing research in the Calumet watershed since 1979 and it is one of only two long-term observational study watersheds that discharge directly into Lake Superior (Stottlemyer and Toczydlowski 2006). A Parshall flume equipped with a Stevens pressure transducer (Stevens Water Monitoring Systems Inc., Portland, Oregon) and Li-Cor datalogger (Li-Cor, Lincoln, Nebraska) is installed near the mouth of the watershed to continuously monitor discharge (Stottlemyer and Toczdylowski, 2006). 


\section{Methods}

In-stream spiraling of $\mathrm{NH}_{4}$ and $\mathrm{SRP}$ was measured at least monthly for three years and DOC for two years. In spring measurements were measured at two week intervals because we expected nutrient uptake would vary in response to rapidly changing environmental conditions following snow-melt. We used short-term continuous injections of $\mathrm{NH}_{4}\left(\mathrm{NH}_{4} \mathrm{Cl}\right)$, phosphate $\left(\mathrm{KH}_{2} \mathrm{PO}_{4}\right)$, and glucose $\left(\mathrm{C}_{6} \mathrm{H}_{12} \mathrm{O}_{6}\right)$ with $\mathrm{NaCl}$ or Rhodamine WT dye as conservative tracers. $\mathrm{NH}_{4}$ and $\mathrm{PO}_{4}$ were added together and a separate glucose injection was conducted after at least two hours or often more than one day. We set up a $200 \mathrm{~m}$ stream reach to achieve a target travel time of 30 minutes to 1 hour, although travel time varied depending on season/discharge. We targeted an enrichment of 10 to $12 \mu \mathrm{g} \mathrm{L}^{-1}$ above background for $\mathrm{NH}_{4}$ and SRP and $5 \mathrm{mg} \mathrm{L}^{-1}$ above background for DOC. Background water samples were collected and filtered $(0.45 \mu \mathrm{m})$ immediately before nutrient addition at 7 locations downstream of the nutrient injection point, and water samples were again collected when conservative tracer concentrations at the downstream end of the reach reached plateau levels. For each date we calculated nutrient spiraling metrics following standard approaches (Newbold et al. 1981; Appendix A). Here, we report nutrient uptake velocity $\left(V_{\mathrm{f}}\right)$, the rate of biotic demand by stream biota (Newbold et al. 1981), because it standardizes for discharge allowing for comparisons among dates with variable flow conditions (Davis and Minshall 1999).

Ammonium was analyzed using the fluorometric method (Holmes et al. 1999, modified by Taylor et al. 2007) on an Aquafluor handheld fluorometer (Turner Designs, Sunnyvale, California) on the date of collection. Rhodamine WT concentrations were determined within 5 hours of collection also using the Aquafluor handheld fluorometer. 
SRP samples were frozen prior to analysis following the ascorbic acid method (APHA 2005) on a spectrophotometer (Thermo Scientific GENESYSTM 10s UV-Vis spectrophotometer, Waltham, MA, USA). To determine DOC and TDN concentrations, samples were acidified and analyzed using a TOC-5000A analyzer (Shimadzu Scientific Instruments, Columbia, Maryland). Chloride was determined using ion chromatography (Dionex ICS-900 Ion Chromatograph, Sunnyvale, CA, USA).

To identify potential factors that may affect variability in nutrient uptake we measured biofilm chlorophyll a and ash-free dry mass (AFDM), canopy cover, water temperature, background nutrient concentrations and DOM composition, and discharge on each sampling date. Because biofilms can be responsible for the removal of nutrients from the water column we measured biofilm chlorophyll a and AFDM (Appendix B). Chlorophyll a provides an estimate of algal biomass (Steinman et al. 2007) and AFDM represents the total living and dead organic material present (Appendix B). Light availability controls autotrophic organism activity; as a proxy for light availability, we determined the percent canopy cover by using a densiometer on each date at each of the 7 sampling locations along the reach. In winter we determined the percent ice/snow cover rather than canopy cover. Additionally, on one summer date we estimated leaf area index (LAI, $\mathrm{m}^{2}$ leaf $\mathrm{m}^{-2}$ ground) and diffuse non-interceptance (DIFN \%), or canopy openness, along the reach (Appendix C).

Water chemistry metrics can affect biotic activity; to determine water chemistry metrics (water temperature, dissolved oxygen, turbidity, conductivity, and $\mathrm{pH}$ ) we deployed a YSI multiparameter sonde at the downstream end of the reach during each injection. Nutrient limitation of essential nutrients may limit autotrophic or heterotrophic 
activity, thus to determine whether background nutrient concentrations $\left(\mathrm{NH}_{4}, \mathrm{SRP}, \mathrm{DOC}\right.$, and TDN) were predictors of $\mathrm{V}_{\mathrm{f}}$ we measured concentrations on each sampling date as described above.

The quality of DOM can be an important factor controlling heterotrophic activity. To determine DOM composition filtered $(0.45 \mu \mathrm{m})$ water samples were collected at least monthly in 2013 and 2014 only, with more frequent collection in spring and fall. To determine $\mathrm{SUVA}_{254}$, an indicator of $\mathrm{C}$ aromaticity, background water samples from all nutrient injections were analyzed for UV absorbance at $254 \mathrm{~nm}$ using a spectrophotometer (Thermo Scientific GENESYS ${ }^{\mathrm{TM}}$ 10s UV-Vis spectrophotometer, Waltham, MA, USA). SUVA 254 was calculated as the UV absorbance at $254 \mathrm{~nm}$ wavelength divided by the DOC concentration (Weishaar et al. 2003). Samples were analyzed for Excitation Emission Matrices (EEMs) on a Jobin-Yvon Horiba Fluoromax$3^{\mathrm{TM}}$ fluorometer (Jobin Yvon Horiba, France) and fluorescing components were determined through a parallel factor analysis (PARAFAC; Appendix D). The six fluorescent components (C1-C6, expressed as a relative percent) identified by PARAFAC and fluorescence index (FI) identified by fluorometric measurements (Appendix D) were included as indicators of DOM composition in further analyses.

To determine if uptake velocity varied seasonally we used a non parametric Kruskal-Wallis grouped by season which was defined based on measured environmental conditions characteristic of each season (see Appendix E for seasonal definitions). We used a non-parametric test because a different number of dates with detectable uptake were observed in each season. Due to the few dates with detectable uptake we were unable to perform this analysis for SRP and DOC. 
To identify which covariates were related to variability in nutrient uptake velocity, we used a two step approach. First, we used partial least squares (PLS) analysis to identify important predictor variables, and followed this with multiple regression analysis using only the highly influential predictors identified by PLS. PLS is a multivariate approach that is less sensitive to correlation among predictor variables and deviations from normality. For PLS analysis nutrient uptake velocity was included as the response variable and the following were included as predictor variables: stream temperature, discharge, canopy cover, conductivity, dissolved oxygen, $\mathrm{pH}$, benthic chlorophyll a, AFDM, TDN, $\mathrm{NH}_{4}$, SRP, DOC, FI, SUVA $254, \mathrm{C} 1, \mathrm{C} 2, \mathrm{C} 3, \mathrm{C} 4, \mathrm{C} 5$, and C6. We used MATLAB (MATLAB ${ }^{\circledR}$ ) with the PLS Toolbox (Eigenvector Research Inc.) to perform the PLS analysis. The location of variables within a PLS biplot represents the correlation structure among variables. Variables located near each other are positively correlated, variables opposite each other are negatively correlated, and variables located near the origin have little influence on the model. The greater distance from the origin for a variable the greater its overall influence on the model (Kothawala et al. 2014). We used variable influence on projections scores (VIP scores) to interpret the importance of the $\mathrm{X}$ variables on the overall model, and defined variables with VIP score $\leq 1$ as highly influential, between 0.8 and 1 as moderately influential, and $<0.8$ less influential predictors. To maximize the number of covariates included in the models we used only dates between 28 March 2013 and 13 August 2014 when DOM composition was characterized. Outliers identified using the Hotelling's $\mathrm{T}^{2}$ analysis were removed if they exceeded the $95 \%$ confidence limit. 
Multiple regression models using predictor variables that were highly influential variables in PLS were evaluated using Akaike's information criteria (AIC). The best model(s) were selected based on the smallest AIC and only models greater than two AIC units than the null model were considered (Burnham and Anderson 2002).

\section{Results}

Consistent with our hypothesis, we found the greatest uptake velocities of $\mathrm{NH}_{4}$ in fall and spring, of SRP in spring, and DOC in fall (Fig. 16). Kruskal-Wallis test indicated there was not a significant effect of season on $\mathrm{NH}_{4} \mathrm{~V}_{\mathrm{f}}\left(\mathrm{X}^{2}=7.04, \mathrm{df}=3, \mathrm{p}=0.07\right)$. In October 2013, during leaf fall, we observed the greatest uptake velocity of $\mathrm{NH}_{4}(8.0 \mathrm{~mm}$ $\left.\mathrm{min}^{-1}\right)$ and DOC, but uptake of SRP was undetectable. In 2012 high $\mathrm{NH}_{4} \mathrm{~V}_{\mathrm{f}}(6.2 \mathrm{~mm}$ $\min ^{-1}$ ) was also observed in fall (November). Uptake of DOC was observed in October 2012 although $\mathrm{V}_{\mathrm{f}}$ was much lower $\left(0.15 \mathrm{~mm} \mathrm{~min}^{-1}\right)$ than in $2013\left(5.3 \mathrm{~mm} \mathrm{~min}^{-1}\right)$. Unfortunately, we were unable to quantify uptake of $\mathrm{NH}_{4}$ in October 2012 due to depletion of the added $\mathrm{NH}_{4}$ prior to the third sampling station. However, this suggests that $\mathrm{NH}_{4}$ uptake was exceptionally high on that date. Additionally, we were unable to measure uptake of $\mathrm{NH}_{4}$, SRP or DOC due to extremely low discharge in September 2012. The greatest $\mathrm{NH}_{4} \mathrm{~V}_{\mathrm{f}}$ and $\mathrm{SRP} \mathrm{V}_{\mathrm{f}}$ observed in 2012 occurred in April with $\mathrm{NH}_{4} \mathrm{Vf}$ peaking in early April $\left(6.6 \mathrm{~mm} \mathrm{~min}^{-1}\right)$ and $\mathrm{SRP} \mathrm{V}_{\mathrm{f}}$ peaking in late April $\left(4.0 \mathrm{~mm} \mathrm{~min}^{-1}\right)$. High $\mathrm{NH}_{4} \mathrm{~V}_{\mathrm{f}}$ measurements were observed for much of the spring (3.1 to $5.7 \mathrm{~mm} \mathrm{~min}^{-1}$ in March, April, and late May; Fig. 16) and only one other date of detectable SRP $V_{f}$. Peaks in $\mathrm{NH}_{4}$ and $\mathrm{SRP} \mathrm{V}_{\mathrm{f}}$ occurred earlier in 2012 than in 2013 or 2014, consistent with earlier spring snowmelt in 2012 (Fig. 16). High $\mathrm{NH}_{4}$ and $\mathrm{SRP} \mathrm{V}_{\mathrm{f}}$ was also observed in 2013 following snowmelt in early June $\left(6.4 \mathrm{~mm} \mathrm{~min}^{-1}\right.$; SRP $\left.5.4 \mathrm{~mm} \mathrm{~min}^{-1}\right) . \mathrm{NH}_{4} \mathrm{~V}_{\mathrm{f}}$ was also 
high in May (4.2 to $4.3 \mathrm{~mm} \mathrm{~min}^{-1}$ in May), but SRP Vf was undetectable on other spring dates. In $2014 \mathrm{SRP} \mathrm{V}_{\mathrm{f}}$ following snowmelt peaked in late May (7.6 mm min-1). $\mathrm{NH}_{4} \mathrm{~V}_{\mathrm{f}}$ was not as high as in previous years and peaked following snowmelt in mid June $(2.1 \mathrm{~mm}$ $\min ^{-1}$ ). Although high $V_{f}$ was observed in spring not all spring measurements revealed high uptake velocity of $\mathrm{NH}_{4}$ and SRP. DOC $\mathrm{V}_{\mathrm{f}}$ was not detectable in spring in either year (Fig. 16).

Despite low temperatures and the occasional presence of ice cover, we observed uptake of $\mathrm{NH}_{4}$ on five winter dates $\left(\mathrm{V}_{\mathrm{f}}=\right.$ non-detectable to $\left.2.3 \mathrm{~mm} \mathrm{~min}^{-1}\right)$ and rates were comparable to those during summer baseflow measurements (non-detectable to $5.7 \mathrm{~mm}$ $\left.\mathrm{min}^{-1}\right)$. SRP $\mathrm{V}_{\mathrm{f}}$ (non-detectable to $3.0 \mathrm{~mm} \mathrm{~min}^{-1}$ ) was detectable on two winter dates in January of 2013 and 2014. DOC $V_{f}$ was not detectable in winter in either year (Fig. 1). Summer baseflow measurements of $\mathrm{NH}_{4} \mathrm{~V}_{\mathrm{f}}$ (non-detectable to $5.7 \mathrm{~mm} \mathrm{~min}^{-1}$ ) and $\mathrm{SRP} \mathrm{V}_{\mathrm{f}}$ (1.2 to $2.2 \mathrm{~mm} \mathrm{~min}^{-1}$ ) were generally low. In July 2013 elevated $\mathrm{NH}_{4} \mathrm{~V}_{\mathrm{f}}\left(3.3 \mathrm{~mm} \mathrm{~min}^{-1}\right)$ relative to other summer measurements was observed, and this measurement was taken approximately one week following a major storm event which scoured all periphyton (reflected in chlorophyll a data). The undetectable uptake of $\mathrm{NH}_{4}$ and SRP observed in July 2014 was due to insufficiently increasing background concentration. Summer DOC $\mathrm{V}_{\mathrm{f}}$ was generally low (non-detectable to $1.5 \mathrm{~mm} \mathrm{~min}^{-1}$ ), but was high in June 2013 (4.3 $\left.\mathrm{mm} \min ^{-1}\right)$.

In the PLS model, 5 latent variables (LV) were identified which collectively explained $89 \%$ of the variance in the $\mathrm{Y}$ variable $\left(\mathrm{NH}_{4} \mathrm{~V}_{\mathrm{F}}\right)$ and $87 \%$ of the variability among $\mathrm{X}$ variables (Table 13). The first axis (LV1) represented a gradient of DOC concentrations, $\mathrm{C}$ aromaticity and discharge; discharge, DOC and $\mathrm{SUVA}_{254}$ had positive 
loadings, and $\mathrm{C} 3$, and FI had strong negative loadings. The second axis (LV2)

represented a gradient of $\mathrm{NH}_{4}$ concentration; $\mathrm{C} 3, \mathrm{C} 2, \mathrm{FI}$ and conductivity had positive loadings, and $\mathrm{NH}_{4}, \mathrm{C} 4$, and canopy cover had negative loadings along LV2 (Figure 17a).

The PLS model identified canopy cover, $\mathrm{NH}_{4}$, DOC, AFDM, chlorophyll a, conductivity, and $\mathrm{pH}$ as highly influential variables and C3, $\mathrm{SUVA}_{254}$, TDN, C6, FI, temperature, $\mathrm{SRP}, \mathrm{C} 4, \mathrm{C} 1, \mathrm{C} 5, \mathrm{C} 2$, discharge, and $\mathrm{DO}$ as less influential predictors (Figure 17a). No moderately influential variables were identified. Following PLS analysis we used multiple regression models including the highly influential variables to further identify predictors of $\mathrm{NH}_{4} \mathrm{~V}_{\mathrm{f}}$ and found 2 significant models (Table 14). The best model explained $60 \%$ of the variability in $\mathrm{NH}_{4} \mathrm{~V}_{\mathrm{f}}$ and included 5 covariates including canopy cover, benthic chlorophyll a, conductivity, and $\mathrm{pH}$ (Table 14). The second model explained $55 \%$ of the variability in $\mathrm{NH}_{4} \mathrm{~V}_{\mathrm{f}}$ and included four covariates: canopy cover, benthic chlorophyll a, and conductivity (Table 14).

Due to the number of dates when SRP and DOC $\mathrm{V}_{\mathrm{f}}$ was not detectable, we did not use PLS models to predict SRP and DOC $V_{f}$. Multiple regression was used to identify predictors of SRP $V_{\mathrm{f}}$ using the 10 dates with detectable uptake: conductivity and temperature were excluded as covariates in this analysis due to correlation with other variables. No significant predictors of $\mathrm{SRP} \mathrm{V}_{\mathrm{f}}$ were identified.

\section{Discussion}

Winter nutrient processing has seldom been measured in streams, particularly in regions that receive a significant snowpack. Extremely low temperatures and coverage of ice and snow were observed at Calumet watershed in winter but despite these potential limitations $\mathrm{NH}_{4}$ and SRP uptake was still observed and was similar to summer baseflow 
measurements. We did not observe uptake of DOC in winter, but concurrent measurements of biodegradable DOC at this and another regional watershed revealed that a high percentage of DOC is biodegradable and autochthonously derived during some winter months (Coble et al., in preparation). Furthermore, we observed high concentrations of benthic algal biomass as chlorophyll a during the winter months, suggesting that increased production of chlorophyll a may occur beneath the ice in this stream (Appendix B; Figure B1). Collectively, our results demonstrate that winter can be an important period for in-stream nutrient processing and should not be ignored.

In temperate forested streams, cycling of carbon and nitrogen are tightly coupled (Bernhardt and Likens 2002, Coble et al. in review) and in this study we found the greatest uptake of $\mathrm{NH}_{4}$ and $\mathrm{DOC}$ occurred in October during the leaf-fall period. Furthermore, the multiple regression analysis identified DOC as a highly influential predictor of $\mathrm{NH}_{4}$ uptake velocity, likely because background stream DOC concentrations were greatest in spring and fall, which were both seasons when $\mathrm{NH}_{4}$ uptake was elevated. A laboratory incubation of stream water collected from Calumet watershed revealed C mineralization rates were stimulated by additions of $\mathrm{NH}_{4}$ and as glucose in October, when leaf litter carbon inputs were greatest (Coble et al., in review). Collectively, these two studies suggest that even as large quantities of carbon subsidies enter the stream from leaf fall, availability of labile $\mathrm{DOC}$ and $\mathrm{NH}_{4}$, can limit heterotrophic breakdown of leaf litter substrates. In contrast we did not observe uptake of SRP during the leaf fall season despite that others have observed elevated uptake of inorganic P during leaf fall in forested streams (Mulholland et al. 1985). Heterotrophic breakdown of organic matter appears to be $\mathrm{N}$ and not $\mathrm{P}$ limited in this stream. 
The peak $\mathrm{NH}_{4} \mathrm{~V}_{\mathrm{f}}$ observed in fall and spring and peak SRP $\mathrm{V}_{\mathrm{f}}$ observed in spring each year were likely the result of increased demand for inorganic nutrients in response to allochthonous organic matter inputs (received via leaf litter and snowmelt) and increased light availability, consistent with our original hypothesis. Modeling results supported this hypothesis by revealing that light availability, stream chemistry (conductivity, $\mathrm{pH}$, background $\mathrm{NH}_{4}$ and DOC concentrations), and biofilm chlorophyll a and AFDM were all highly influential predictors of $\mathrm{NH}_{4} \mathrm{~V}_{\mathrm{f}}$. Within each season a high degree of temporal variability in nutrient uptake velocities were observed, which is likely explained by rapidly changing conditions altering these physical, chemical, and biological variables. For example, in forested streams during spring runoff DOC increases to a peak and then declines as snowmelt progresses, while $\mathrm{pH}$ decreases and then increases following snowmelt (Buffam et al. 2007). During the leaf-on season in summer only $5 \%$ of light passes through the canopy at this stream while canopy cover varies from 54 to $95 \%$ throughout the year (Appendix C). We found that peak uptake for each year of our study occurred approximately one month following peak spring discharge for $\mathrm{NH}_{4}$ (28 to 40 days) and SRP (22 to 41 days), presumably allowing biofilms to reestablish following scouring by spring floods and increasing autotrophic demand for inorganic nutrients. Interestingly, we found a similar response in $\mathrm{NH}_{4}$ uptake demand following a major summer flood event, which scoured biofilms and resulted in high $\mathrm{NH}_{4} \mathrm{~V}_{\text {f. }}$ Thus, the timing of these changes in relation to other important variables appear to influence nutrient uptake demand in this temperate forested stream.

Our results are consistent with other studies that have found that $\mathrm{NH}_{4}$ or $\mathrm{NO}_{3}$ uptake peaks in spring in streams (Hoellein et al. 2007, Roberts and Mulholland 2007). 
For example, Hall et al. (2009) found that high levels of $\mathrm{N}$ uptake occurred during both snowmelt and baseflow conditions in an Idaho stream (Hall et al. 2009). However, in their study of 4 streams in Michigan's Upper Peninsula, Hoellein et al. (2007) did not identify peaks in $\mathrm{NH}_{4}$ uptake in fall, which may be due to the timing of their sampling dates in relation to leaf fall (October and December but not November). However, they did attribute high rates of $\mathrm{NH}_{4}$ uptake in December to $\mathrm{C}$ inputs from prior leaf fall. Our results suggest that within the fall season, $\mathrm{NH}_{4} \mathrm{~V}_{\mathrm{f}}$ was temporally variable and high rates of uptake may occur for relatively short periods of time. Moreover, detecting these rapid uptake velocities required drastically shortening the reach length; thus, we were unable to quantify the high uptake in October 2012 but were able to do so when we shortened the study reach used in October 2013.

Our finding that a suite of physical, chemical, and biological variables are important in determining year-round patterns in $\mathrm{NH}_{4}$ uptake in streams suggests that the relative timing of abiotic factors and biotic responses are critical to determining in-stream nutrient demand, and if climate change alters this timing then we may expect changes in seasonal patterns of nutrient uptake. For example, a reduction in the duration ice cover in streams, as is expected for northern temperate lakes in a warming climate (e.g., Magnuson et al. 1997), will increase light availability earlier in the spring season. Furthermore, a reduction in the quantity of winter snow can cause earlier spring runoff and reduce the magnitude of spring flows, thereby affecting concentrations of DOC and other solutes (e.g., Schindler et al. 1997). Collectively, these alterations could allow for a longer spring period of elevated $\mathrm{NH}_{4}$ uptake prior to leaf out. With climate change we may expect seasonal shifts in light availability, nutrient inputs, or algal biomass to occur 
in spring and fall, times when nutrient uptake of $\mathrm{N}, \mathrm{P}$, or $\mathrm{C}$ are elevated. Variability in nutrient uptake will alter rates and timing of nutrient or carbon export to downstream ecosystems that utilize these inputs to fuel downstream productivity.

\section{Acknowledgements}

We thank B. Borowitz, A.P. Coble, E. Collins, J. Ebel, D. Fenlon, K. Heiden, K. Meingast, J. Olson, J. Ortiz, and T. Veverica for assistance in the field and lab. Thanks to M. Cavaleri for equipment and to R. Stottlemyer and D. Toczydlowski for providing long-term monitoring data. Funding for this research was provided by: Michigan Technological University’s Research Excellence Fund, USDA McIntire-Stennis Fund, Michigan Technological University’s Ecosystem Science Center, and Michigan Technological University's Center for Water and Society. A.Coble was supported with a fellowship from the National Science Foundation's GK-12 Global Watershed program (DGE-0841073).

\section{Literature Cited}

APHA. 2005. Standard methods for the examination of water and wastewater. American Public Health Administration, Washington, D.C., USA.

Alexander, R. B., R. A. Smite, and G. E. Schwarz. 2000. Effect of stream channel size on the delivery of nitrogen to the Gulf of Mexico. Nature 403:758-761.

Bechtold, H. A., A. M. Marcarelli, C. V. Baxter, and R. S. Inouye. 2012. Effects of N, $\mathrm{P}$, and organic carbon on stream biofilm nutrient limitation and uptake in a semiarid watershed. Limnology and Oceanography 57:1544-1554.

Bernhardt, E. S., and G. E. Likens. 2002. Dissolved organic carbon enrichment alters nitrogen dynamics in a forest stream. Ecology 83:1689-1700. 
Bernhardt, E. S., G. E. Likens, R. O. Hall Jr., D. C. Buso, S. G. Fisher, T. M. Burton, J. L. Meyer, W. H. McDowell, M. S. Mayer, W. B. Bowden, S. E. G. Findlay, K. H. Macneale, R. S. Stelzer, and W. H. Lowe. 2005. BioScience 55:219-230.

Buffam, I., H. Laudon, J. Temnerud, C. Mörth, and K. Bishop. 2007. Landscape-scale variability of aciditiy and dissolved organic carbon during spring flood in a boreal stream network. Journal of Geophysical Research 112, G01022.

Burnham, K. P., and D. R. Anderson. 2002. Model selection and multimodel inference: a practical information-theoretic approach. Second edition. Spring Science Business Media, New York, New York, USA

Coble, A. A., A. M. Marcarelli, and E. S. Kane. In review. Nutrient limitation of dissolved organic carbon mineralization in a Lake Superior tributary, Journal of Great Lakes Research

Davis, J. C., and G. W. Minshall. 1999. Nitrogen and phosphorus uptake in two Idaho (USA) headwater wilderness streams. Oecologia 119:247-255.

Goodale, C. L. and J. D. Aber. 2001. The long-term effects of land-use history on nitrogen cycling in northern hardwood forests. Ecological Applications 11:253267.

Groisman, P. Y., R. W. Knight, T. R. Karl, D. R. Easterling. 2004. Contemporary changes of the hydrological cycle over the contiguous United States: trends derived from in situ observations. Journal of Hydrometeorology 5:64-85.

Hall, R. O., E. S. Bernhardt, and G. E. Likens. 2002. Relating nutrient uptake with transient storage in forested mountain streams. Limnology and Oceanography $47: 255-265$. 
Hall, R. O., M. A. Baker, C. D. Arp, and B. J. Koch. 2009. Hydrologic control of nitrogen removal, storage, and export in a mountain stream. Limnology and Oceanography 54:2128-2142.

Henry, H. A. L. 2008. Climate change and soil freezing dynamics: historical trends and projected changes. Climatic Change 87:421-434.

Hoellein, T. J., J. L. Tank, E. J. Rosi-Marshall, S. A. Entrekin, G. A. Lamberti. 2007. Controls on spatial and temporal variation of nutrient uptake in three Michigan headwater streams. Limnology and Oceanography 52:1964-1977.

Holmes, R. M., A. Aminot, R. Kerouel, B. A. Hooker, and B. J. Peterson. 1999. A simple and precise method for measuring ammonium in marine and freshwater ecosystems. Canadian Journal of Fisheries and Aquatic Sciences 56:1801-1808.

Johnson, L. T., J. L. Tank, and C. P. Arango. 2009. The effect of land use on dissolved organic carbon and nitrogen uptake in streams. Freshwater Biology 54:23352350.

Judd, K. E., G. E. Likens, D. C. Buso, and A. S. Bailey. 2011. Minimal response in watershed nitrate export to severe soil frost raises questions about nutrient dynamics in the Hubbard Brook experimental forest. Biogeochemistry 106:443459, doi 10.1007/s10533-010-9524-4

Kothawala, D. N., C. A. Stedmon, R. A. Müller, G. A. Weyhenmeyer, S. J. Köhler, and L. J. Tranvik. 2014. Controls of dissolved organic matter quality: evidence from a large-scale boreal lake survey. Global Change Biology 20:1101-1114.

Magnusen, J. J., K. E. Webster, R. A. Assel, C. J. Bowser, P. J. Dillon, J. G. Eaton, H. E. Evans, E. J. Fee, R. I. Hall, L. R. Mortsch, D. W. Schindler, and E. H. Quinn. 
1997. Potential effects of climate changes on aquatic systems: Laurentian Great Lakes and Precambrian Shield Region. Hydrological Processes 11:825-871.

Mitchell, M. J., C. T. Driscoll, J. S. Kahl, G. E. Likens, P. S. Murdoch, and L. H. Pardo. 1996. Climatic control of nitrate loss from forested watersheds in the Northeast United States. Environmental Science and Technology 30:2609-2612.

Mortsch, L. D., F. H. Quinn. 1996. Climate change scenarios for Great Lakes Basin ecosystem studies. Limnology and Oceanography 41:903-911.

Mulholland, P. J., J. D. Newbold, J. W. Elwood, L. A. Ferren, and J. R. Webster. 1985. Phosphorus spiraling in a woodland stream: seasonal variations. Ecology 66:1012-1023.

Mulholland, P. J., A. D. Steinman, and J. W. Elwood. 1990. Measurement of phosphorus uptake length in streams: comparison of radiotracer and stable $\mathrm{PO}_{4}$ releases. Canadian Journal of Fisheries and Aquatic Sciences 47:2351-2357.

Newbold, J. D., J. W. Elwood, R. V. O’Neill, and W. Van Winkle. 1981. Measuring nutrient spiraling in streams. Canadian Journals of Fisheries and Aquatic Sciences 38:860-863.

Peterson, B. J., W. M. Wollheim, P. J. Mulholland, J. R. Webster, J. L. Meyer, J. L. Tank, E. Marti, W. B. Bowden, H. M. Valett, A. E. Hershey, W. H. McDowell, W. K. Dodds, S. K. Hamilton, S. Gregory, D. D. Morrall. 2001. Control of nitrogen export from watersheds by headwater streams. Science 292:86-90.

Roberts, B. J., P. J. Mulholland. 2007. In-stream biotic control on nutrient biogeochemistry in a forested stream, West Fork of Walker Branch. Journal of Geophysical Research 112:G04002. 
Schindler, D. W. 1997. Widespread effects of climatic warming on freshwater ecosystems in North America. Hydrological Processes 11:1043-1067.

Steinman, A. D., G. A. Lamberti, and P. R. Leavitt. 2007. Biomass and pigments of benthic algae p. 357-379. In F. R. Hauer and G. A. Lamberti [eds.], Methods of Stream Ecology

Stottlemyer, R., and D. Toczydlowski. 1996. Modification of snowmelt chemistry by forest floor and mineral soil, Northern Michigan. Journal of Environmental Quality 25, 828-836.

Stottlemyer, R., 1997. Streamwater chemistry in watersheds receiving different atmospheric inputs of $\mathrm{H}^{+}, \mathrm{NH}_{4}{ }^{+}, \mathrm{NO}_{3}{ }^{-}$, and $\mathrm{SO}_{4}{ }^{2-}$. Journal American Water Resources Association 33:767-780.

Stottlemyer, R. and D. Toczydlowski. 2006. Effect of reduced winter precipitation and increased temperature on watershed solute flux, 1988-2002, Northern Michigan. Biogeochemistry 77:409-440.

Taylor, B. W., C. F. Keep, R. O. Hall, B. J. Koch, L. M. Tronstad, A. S. Flecker, and A. J. Ulseth. 2007. Improving the fluorometric ammonium method: matrix effects, background fluorescence, and standard additions. Journal of the North American Benthological Society 26:167-177.

Vitousek, P. M., and W. A. Reiners. 1975. Ecosystem succession and nutrient retention: A hypothesis. BioScience 25:376-381.

Watmough, S. A., M. C. Eimers, J. Aherne, and P. J. Dillon. 2004. Climate effects on stream nitrate concentrations at 16 forested catchments in South Central Ontario. Environmental Science and Technology 38:2383-2388. 
Weishaar, J. L., G. R. Aiken, B. A. Bergamaschi, M. S. Fram, R. Fujii, and K. Mopper. 2003. Evaluation of specific ultraviolet absorbance as an indicator of the chemical composition and reactivity of dissolved organic carbon. Environmental Science and Technology 37:4702-4708.

Withers, P. J. A. and H. P. Jarvie. 2008. Delivery and cycling of phosphorus in rivers: a review. Science of the Total Environment 400:379-395. 
Table 13. PLS model for prediction of $\mathrm{NH}_{4} \mathrm{~V}_{\mathrm{f}}(\mathrm{Y}$ variable) performance as a function of the number of PLS latent variables.

\begin{tabular}{llll}
\hline Latent Variable & $\begin{array}{l}\text { X cumulative } \\
\text { variance } \\
\text { explained }\end{array}$ & $\begin{array}{l}\text { Y cumulative } \\
\text { variance } \\
\text { explained }\end{array}$ & RMSECV \\
\hline 1 & 33.54 & 30.80 & 2.39 \\
2 & 43.73 & 58.30 & 3.08 \\
3 & 65.92 & 63.78 & 2.96 \\
4 & 69.97 & 82.62 & 4.73 \\
5 & 78.57 & 86.73 & 5.13 \\
6 & 87.16 & 88.79 & 5.48 \\
\hline
\end{tabular}

Table 14. Multiple regression model results to identify predictors of seasonal variability in $\mathrm{NH}_{4} \mathrm{~V}_{\mathrm{f}}$ at Calumet Watershed.

\begin{tabular}{llllll}
\hline Model & AIC & p-value & $\mathrm{R}^{2}$ adj & w & $\Delta$ AIC \\
\hline CanopyCover+Chla+cond+AFDM+pH & 52.28 & 0.024 & 0.60 & 0.66 & 0 \\
CanopyCover+Chla+cond+AFDM & 53.62 & 0.022 & 0.55 & 0.34 & 1.34 \\
\hline
\end{tabular}




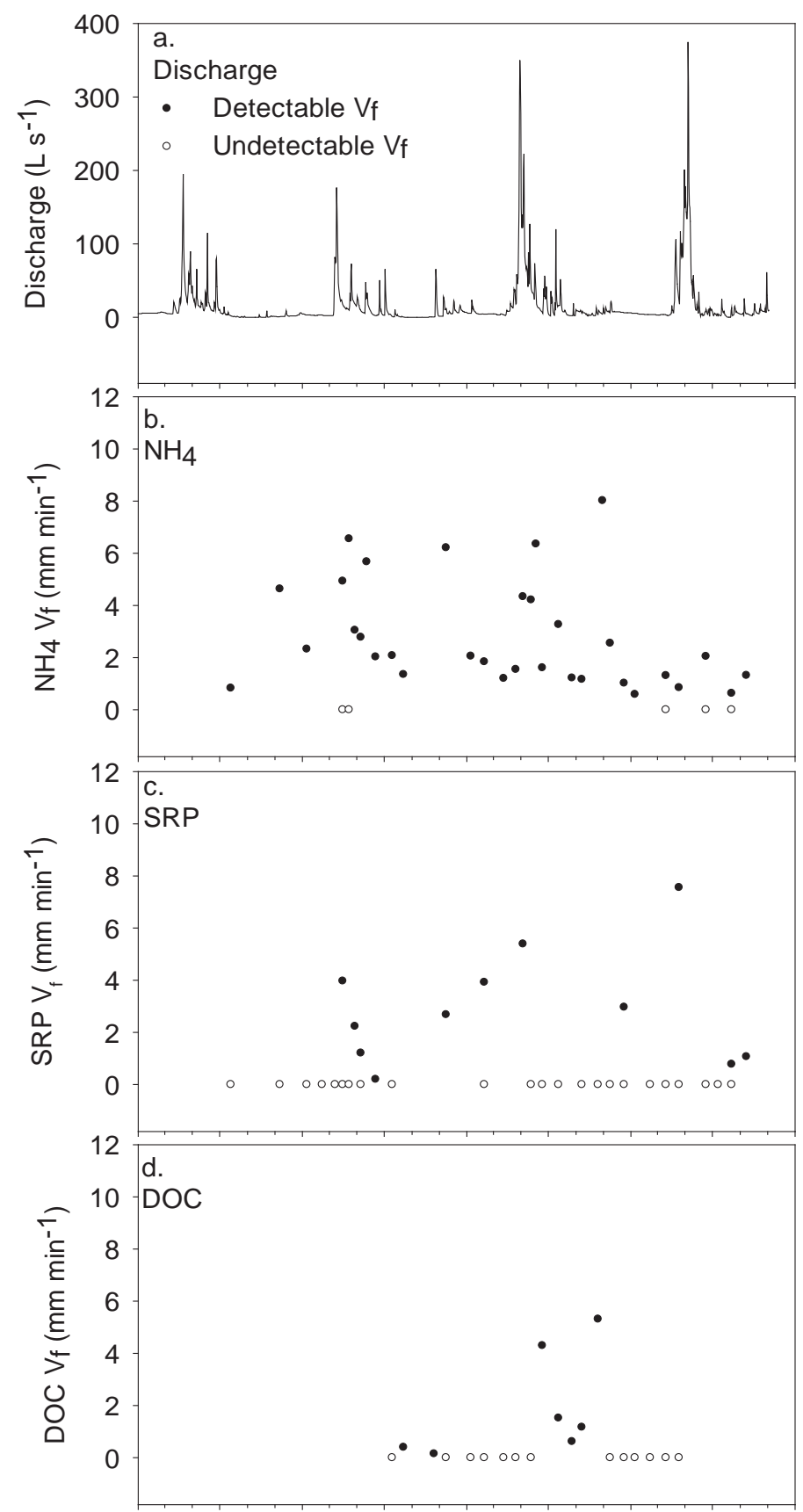

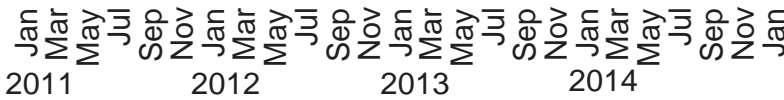

Figure 16. Discharge (a) and uptake velocity $\left(\mathrm{V}_{\mathrm{f}}\right)$ for ammonium $\left(\mathrm{a} ; \mathrm{NH}_{4}\right)$, soluble reactive phosphate (b; SRP), and dissolved organic carbon (d; DOC) in Calumet Watershed. Hatch marks indicate winter conditions, and cross marks indicate summer conditions. 

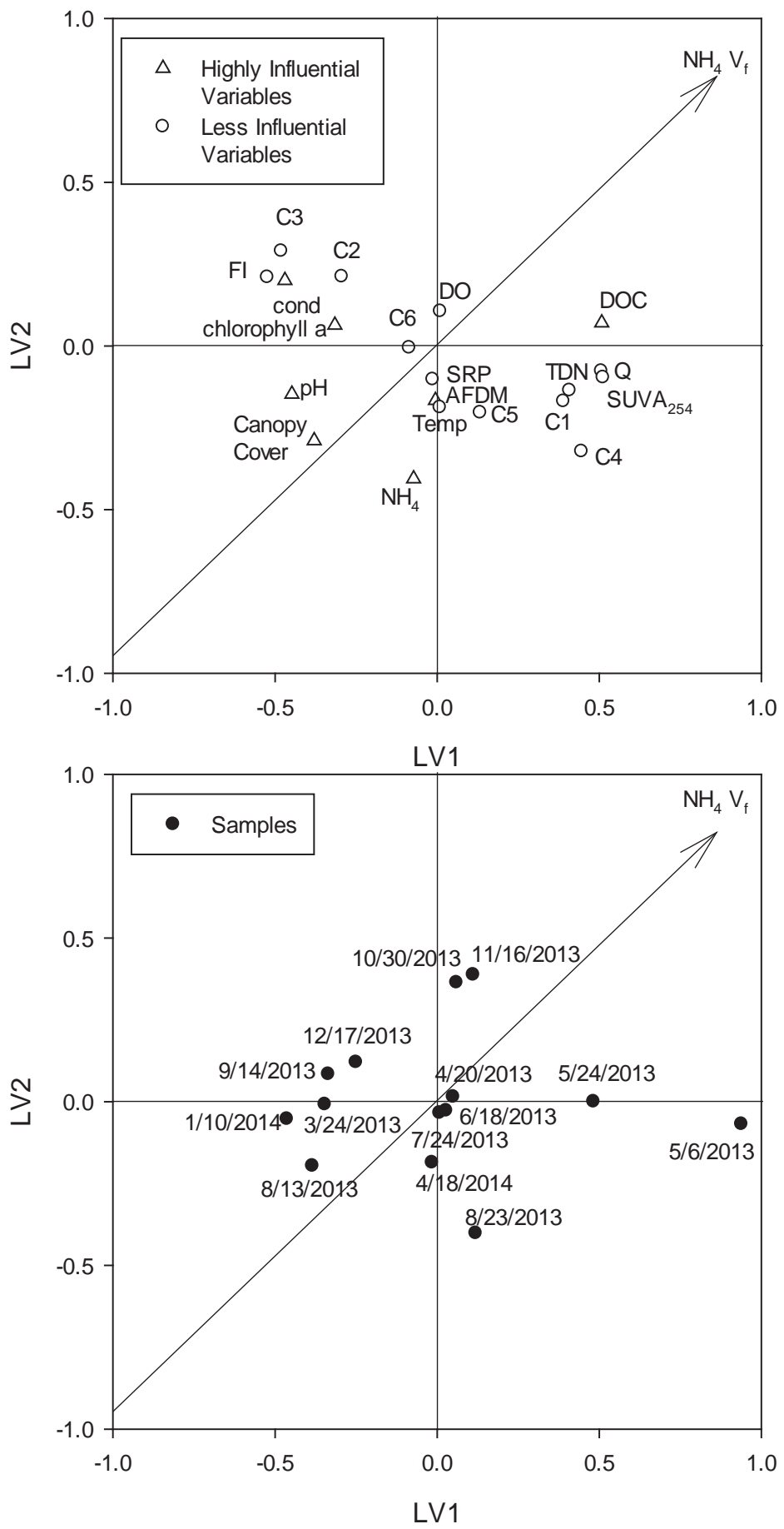

Figure 17. Partial Least Squares analysis of influential variables determining variability in ammonium uptake velocity $\left(\mathrm{NH}_{4} \mathrm{~V}_{\mathrm{f}}\right)$ 


\section{Appendix A: Nutrient uptake measurements}

We corrected plateau nutrient concentrations for background concentrations and normalized these values to the conservative tracer. We then applied a natural log transformation to the normalized background corrected concentrations and plotted it versus distance from the location of the injection and fit a linear model to calculate first order uptake rate coefficient $(\mathrm{k})$. Only significant linear regressions were included $(\mathrm{p}=$ 0.10); for any non-significant regressions uptake was considered undetectable and was not used in further analysis. Uptake length $\left(\mathrm{S}_{\mathrm{w}}\right)$ is the mean distance a nutrient travels downstream in inorganic form before it is taken up and is calculated as: $\mathrm{S}_{\mathrm{w}}=-1 \mathrm{k}^{-1}$. From these values other nutrient spiraling metrics can be calculated (Newbold et al. 1981). Cross sectional widths and depths were measured at each of the 7 sampling locations on each sampling date.

Only significant linear regressions $(\mathrm{p}=0.10)$ were included in determining whether uptake occurred. Note: no p-values were borderline or fell within $p<0.2$ that were identified as undetectable.

\section{References:}

Newbold, J. D., J. W. Elwood, R. V. O’Neill, and W. Van Winkle. 1981. Measuring nutrient spiraling in streams. Canadian Journals of Fisheries and Aquatic Sciences 38:860-863. 


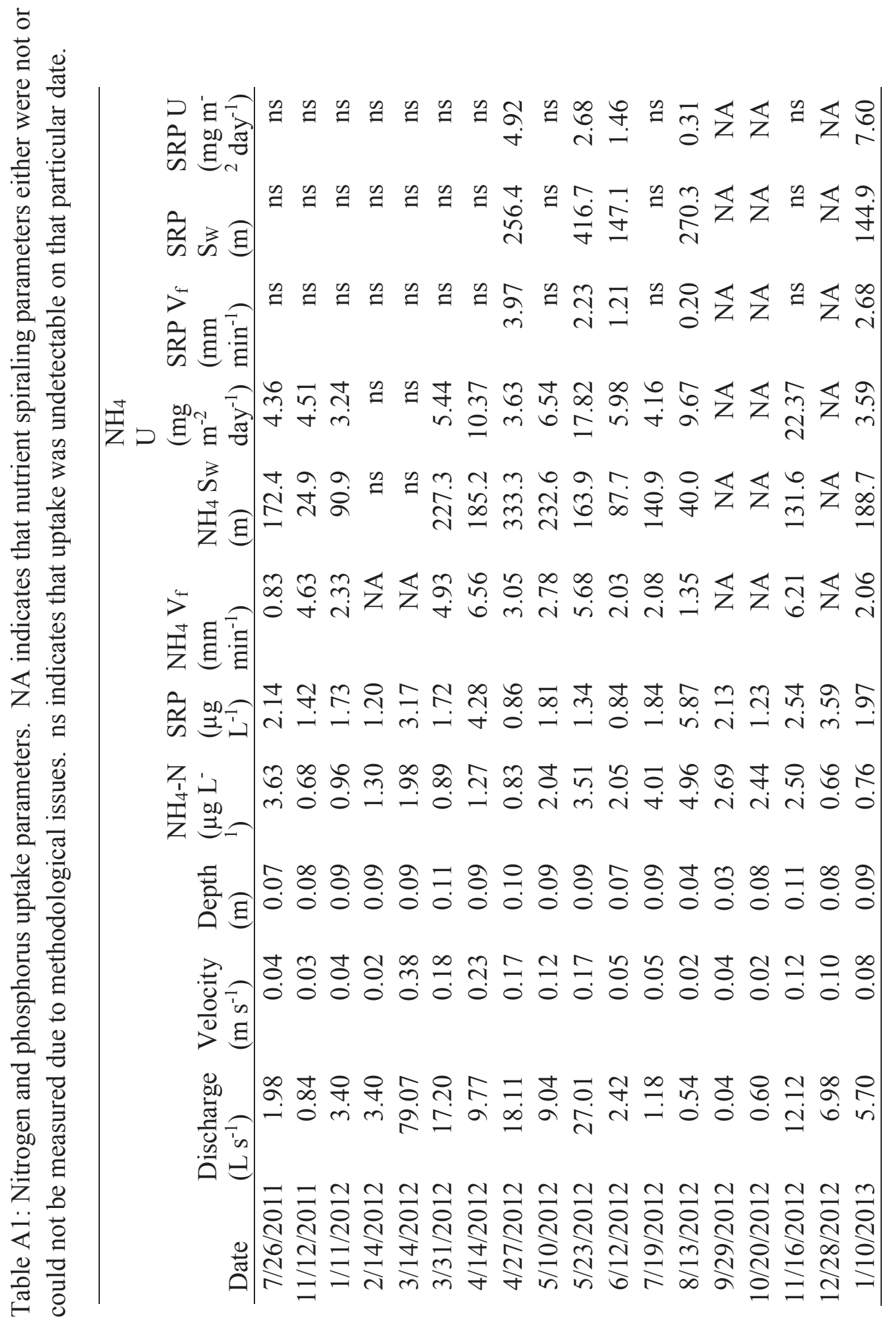




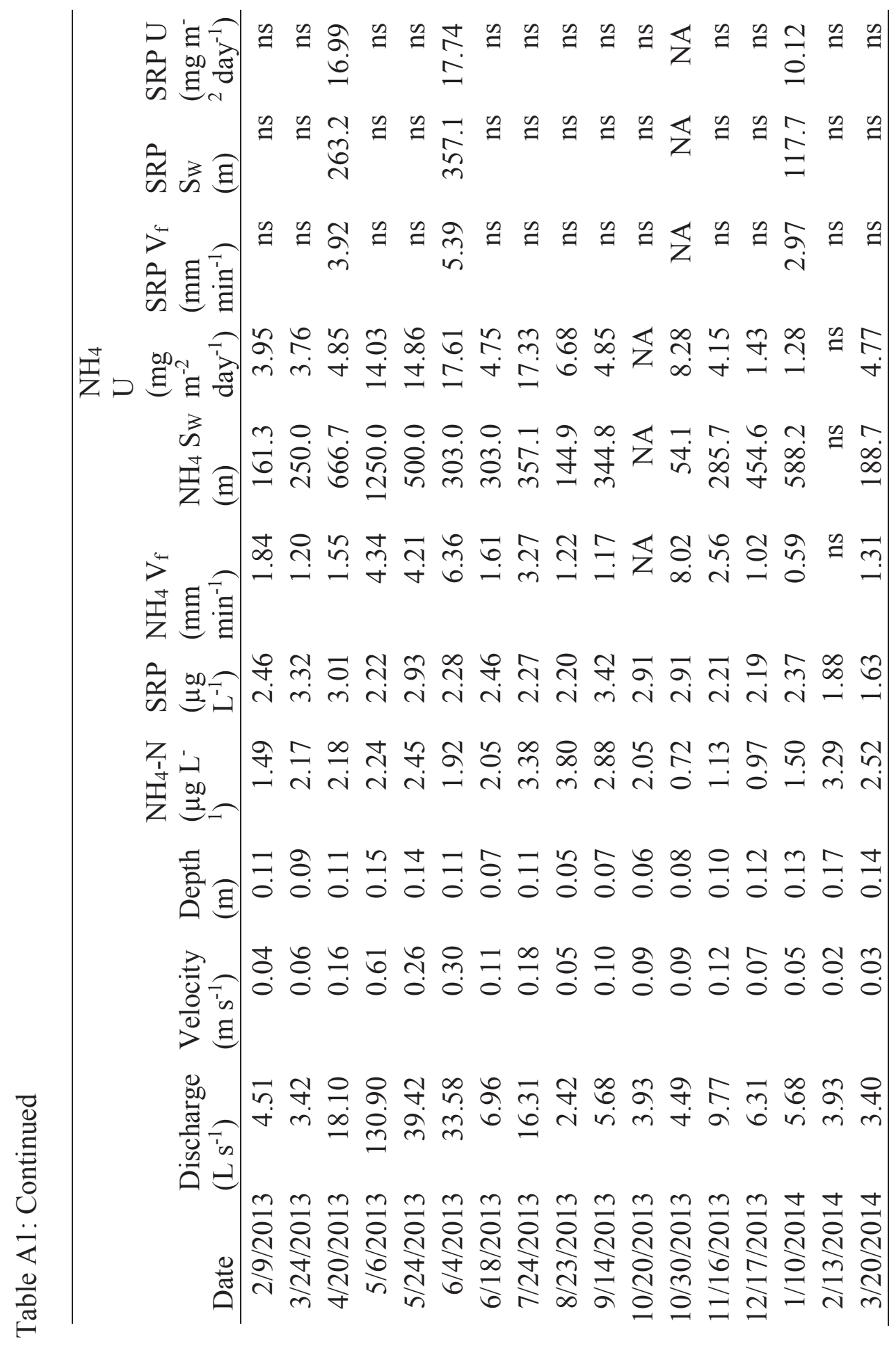




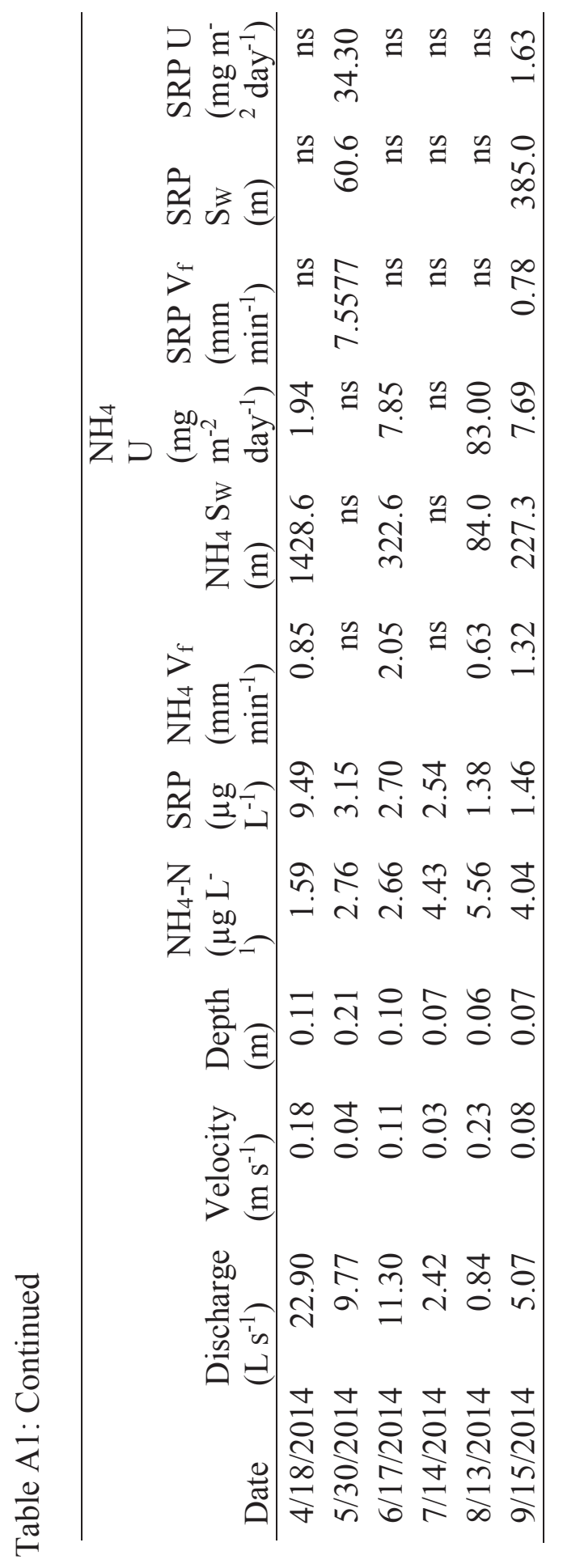




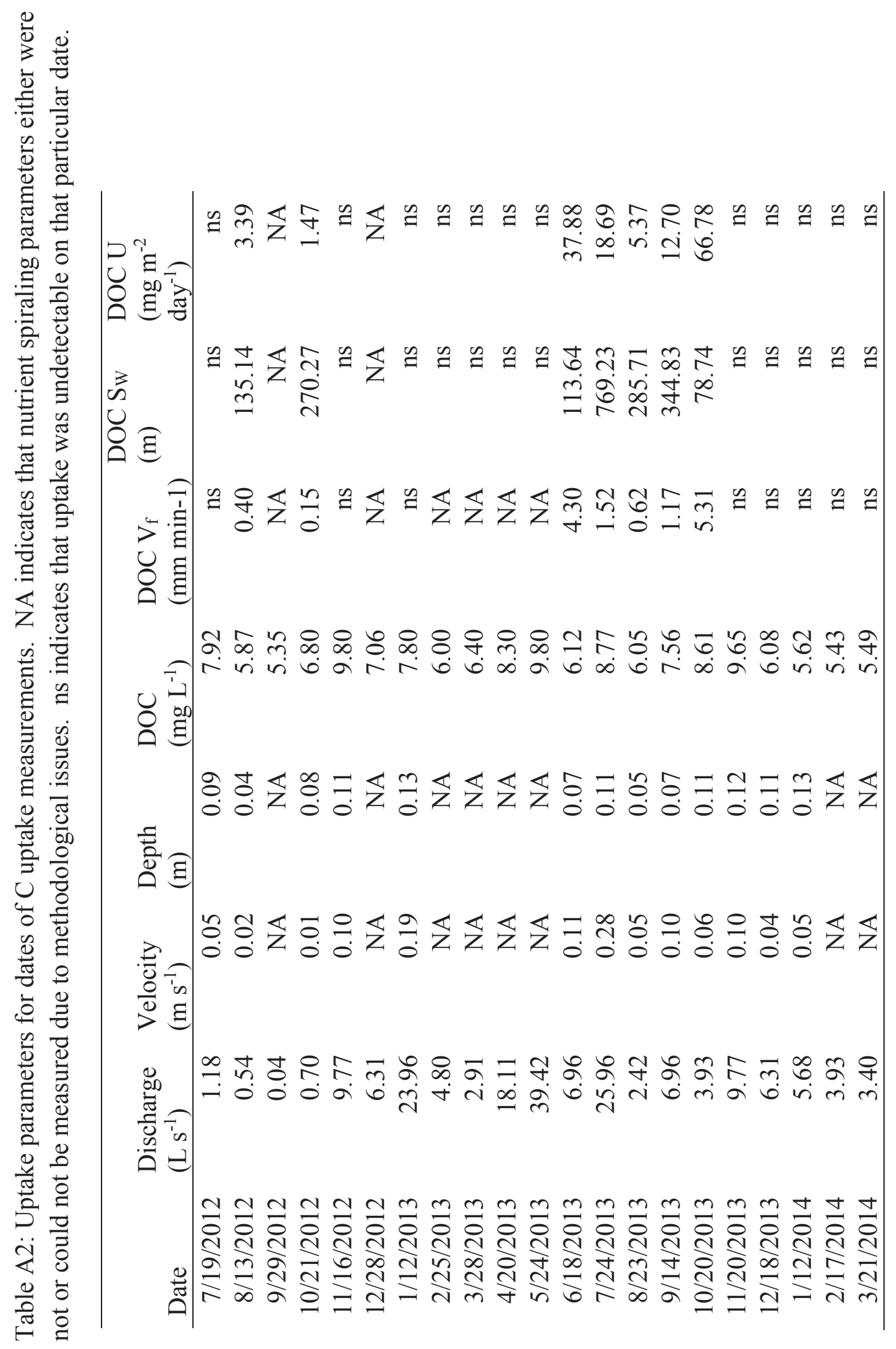




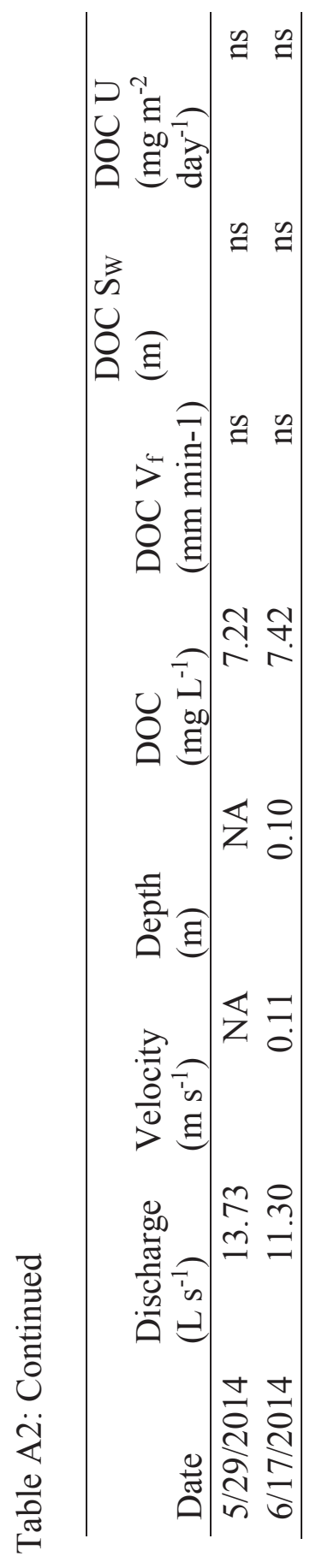




\section{Appendix B: Chlorophyll a and ash-free dry mass}

To measure benthic chlorophyll a and ash-free dry mass (AFDM), three rocks or sediment cores $(1 \mathrm{~cm}$ depth) were collected monthly from each of the 7 locations in the stream reach. All biofilm was removed from the rock surface by scrubbing with a firm brush and rinsing into $\sim 150 \mathrm{~mL}$ of water. Subsamples from the resulting slurry were filtered onto pre-ashed $0.7 \mathrm{~m}$ glass fiber filters and frozen until analysis. We traced the planar rock shape and weighed the resulting cut-out to determine the rock surface area (Bergey and Getty 2006). Periphyton chlorophyll a was analyzed using the spectrophotometric method (APHA 2005, Nusch 1980). Following analysis, AFDM was determined as the difference between the mass of samples (following oxidization in a muffle furnace) and the initial dry mass of those samples. AFDM does not distinguish algal components from other living and dead components of periphyton (i.e. fungi, bacteria, or detritus; (Steinman et al. 2007).

\section{References}

APHA. 2005. Standard methods for the examination of water and wastewater. American Public Health Administration, Washington, D.C., USA.

Bergey, E. A., and G. M. Getty. 2006. A review of methods for measuring the surface area of stream substrates. Hydrobiologia 556:7-16.

Nusch, E. A. 1980. Comparison of different methods for chlorophyll and phaeopigment determination. Archiv für Hydrobiologie-Beiheft 14:14-36. 
Steinman, A. D., G. A. Lamberti, and P. R. Leavitt. 2007. Biomass and pigments of benthic algae p. 357-379. In F. R. Hauer and G. A. Lamberti [eds.], Methods of Stream Ecology

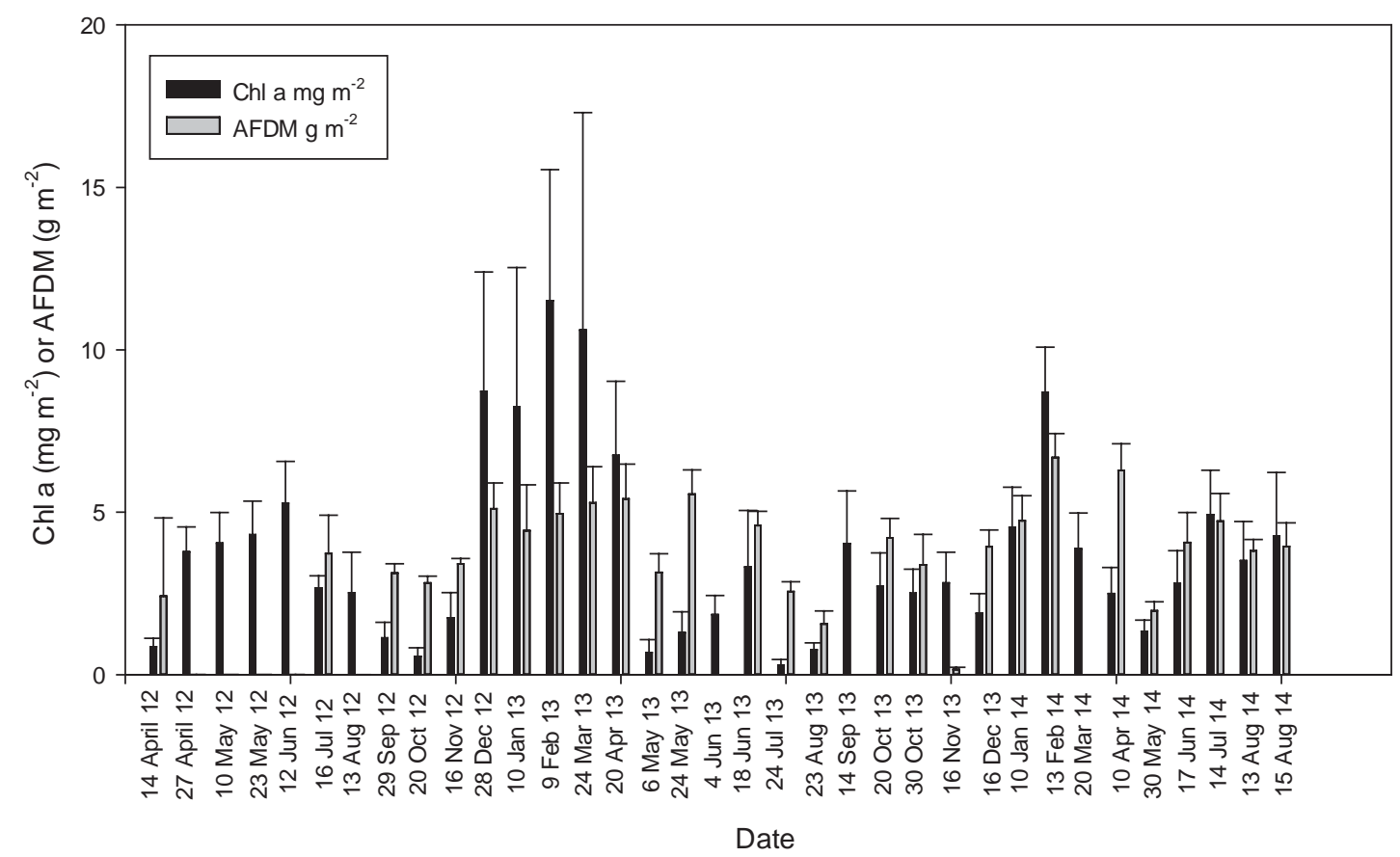

Figure B1. Mean chlorophyll a $\left(\mathrm{mg} \mathrm{m}^{-2}\right)$ and ash-free dry mass (AFDM; $\left.\mathrm{g} \mathrm{m}^{-2}\right)$ measured at Calumet watershed from April 2012 through September 2014. Error bars represent standard error. 


\section{Appendix C: Leaf area index and diffuse non-interceptance}

On one summer date we estimated leaf area index (LAI, $\mathrm{m}^{2}$ leaf $\mathrm{m}^{-2}$ ground) and diffuse non-interceptance (DIFN \%), or canopy openness, at each of the 7 sampling locations along the reach. All light measurements were collected following sunrise within an hour of sunrise using a plant canopy analyzer (LAI 2200, LiCOR, Inc., Lincoln, NE, USA). We collected above-canopy measurements prior to and following below-canopy measurements in a canopy clearing (road) and used a 10 degree view cap to block out forest canopies along the edges of the clearing. At each site, we collected four belowcanopy measurements at four azimuthal directions (N, E, S, W) also using the 45 degree view cap. We used FV-2200 software to linearly interpolate above-canopy light measurements through time that corresponded with below-canopy measurements. The four estimates of DIFN \% and LAI collected at each site were averaged.

Results

During the leaf-on season in summer only $5 \%$ of light passes through the canopy (mean $\mathrm{DIFN}=5 \%$; mean LAI $=4.54 \mathrm{~m}^{2}$ leaf area $\mathrm{m}^{-2}$ ground). Throughout the year canopy cover as measured from a densiometer ranged from 54 to $94 \%$. 


\section{Appendix D: Dissolved organic matter characterization}

Samples for DOM characterization were kept cool and analyzed within 24 hours of collection for excitation-emission fluorescence matrices (EEM) on a Jobin-Yvon Horiba Fluoromax-3 $3^{\mathrm{TM}}$ fluorometer (Jobin Yvon Horiba, France). EEMs were collected every $3 \mathrm{~nm}$ over excitation wavelength intervals between 240 and $600 \mathrm{~nm}$ and every 3.28 $\mathrm{nm}$ over emission wavelength intervals between 212 and $620 \mathrm{~nm}$. Fluorescence spectra were corrected for the inner filter effect. To remove the Raman signal a Raman normalized Milli-Q water sample was removed from each fluorescence spectrum. Fluorescence index (FI) distinguishes between microbial and terrestrial sources of fulvic acids, and was identified from corrected sample EEMs as the ratio of the emission intensity at $450 \mathrm{~nm}$ to $550 \mathrm{~nm}$ acquired at an excitation of 370nm (McKnight et al. 2001).

To identify fluorescing components we used a parallel factor analysis (PARAFAC) on 374 samples collected from regional rivers, Lake Superior's near shore region, soil lysimeter, snow, and precipitation samples. We validated the PARAFAC model with split-half analysis and by examining residuals (Stedmon et al. 2003, Stedmon and Bro 2008). PARAFAC analysis was completed using the PLS-toolbox for Matlab (Eigenvector Research Inc.).

The PARAFAC model identified 6 components (Table 1) all of which have been previously identified in the literature (Table 1). Components 2, 3, and 5 were all identified as humic-like fluorophores, component 1 was identified as a fulvic-like fluorophore, and component 4 was identified as a fulvic-like and humic-like fluorophore. Component 6 was the only protein-like fluorescence component identified and it was 
tryptophan-like. From hereafter, we will refer to the components as the percentage of total fluorescent DOM (e.g. C1).

References

McKnight, D. M., E. W. Boyer, P. K. Westerhoff, P. T. Doran, T. Kulbe, T., and D. T. Anderson. 2001. Spectrofluorometric characterization of dissolved organic matter for indication of precursor organic material and aromaticity. Limnology and Oceanography 46:38-48, doi:10.4319/1o.2001.46.1.0038

Olefeldt D., M. R. Teretsky, and C. Blodau. 2013. Altered composition and microbial versus UV-mediated degradation of dissolved organic matter in boreal soils following wildfire. Ecosystems 16:1396-1412.

Stedmon, C. A., and R. Bro. 2008 Characterizing dissolved organic matter fluorescence with parallel factor analysis: a tutorial. Limnology and Oceanography-Methods 6:572-579, doi:10.4319/lom.2008.6.572

Stedmon, C. A., and S. Markager. 2005a. Resolving the variability in dissolved organic matter fluorescence in a temperate estuary and its catchment using PARAFAC analysis. Limnology and Oceanography 50:686-697.

Stedmon, C. A., and S. Markager. 2005b. Tracing the production and degradation of autochthonous fractions of dissolved organic matter by fluorescence analysis. Limnology and Oceanography 50:1415-1426.

Stedmon, C. A., S. Markager, and R. Bro. 2003 Tracing dissolved organic matter in aquatic environments using a new approach to fluorescence spectroscopy. Marine Chemistry 82:239-254, doi:10.1016/S0304-4203(03)00072-0 
Table D1. Six components identified by parallel factor analysis (PARAFAC) with secondary excitation maxima listed in parentheses.

\begin{tabular}{|c|c|c|c|c|}
\hline Component & $\begin{array}{l}\text { Excitation } \\
\text { maxima } \\
(\mathrm{nm})\end{array}$ & $\begin{array}{l}\text { Emission } \\
\text { maxima } \\
(\mathrm{nm})\end{array}$ & Description & $\begin{array}{l}\text { Similar to previously } \\
\text { identified } \\
\text { components }\end{array}$ \\
\hline 1 & $<250(340)$ & 455 & $\begin{array}{l}\text { Fulvic-like } \\
\text { fluorophore }\end{array}$ & $\begin{array}{l}\text { Stedmon and } \\
\text { Markager, 2005a, C4 }\end{array}$ \\
\hline 2 & $<250$ & 448 & $\begin{array}{l}\text { Humic-like } \\
\text { fluorophore }\end{array}$ & $\begin{array}{l}\text { Stedmon and } \\
\text { Markager, 2005a, C1 }\end{array}$ \\
\hline 3 & $<250(310)$ & 395 & $\begin{array}{l}\text { Humic-like } \\
\text { fluorophore }\end{array}$ & $\begin{array}{l}\text { Stedmon and } \\
\text { Markager, 2005a, C3 }\end{array}$ \\
\hline 4 & $282(380)$ & 514 & $\begin{array}{l}\text { Fulvic-like, Humic- } \\
\text { like, High molecular } \\
\text { weight }\end{array}$ & $\begin{array}{l}\text { Olefeldt et al. } 2013 \text {, } \\
\text { component Cx }\end{array}$ \\
\hline 5 & 277(396) & 477 & $\begin{array}{l}\text { Humic-like } \\
\text { fluorophore }\end{array}$ & $\begin{array}{l}\text { Stedmon and } \\
\text { Markager, 2005b, C7 }\end{array}$ \\
\hline 6 & 279 & 344 & $\begin{array}{l}\text { Tryptophan-like } \\
\text { fluorescence }\end{array}$ & $\begin{array}{l}\text { Stedmon and } \\
\text { Markager, 2005a, C7 }\end{array}$ \\
\hline
\end{tabular}




\section{Appendix E: Seasonal Definitions}

For comparisons among seasons, we selected dates that reflected major hydrologic and phonological events in the region, rather than defaulting to calendar based seasons. This was particularly important to reflect the extended winter snow over in our region. Moreover, we adjusted the dates of each season to reflect the large variation in the timing of peak snowmelt runoff, which ranged between early March and late April within the 3 year duration of our study. For our definitions, winter extended from December until the first sign of spring snowmelt (identified by a rise in the hydrograph) in each year. Spring was defined as starting from the first sign of spring melt and extending until 45 days following peak spring discharge. The end of spring was also determined by an increase in measured canopy cover indicating the beginning of leaf-out. Summer extended from the end of spring until the end of August. Fall was defined as September through November, consistent with observations of leaf fall, which began in September and peaked in October each year. 
Table E1: Seasonal definitions for each year of the study.

\begin{tabular}{lllll}
\hline Year & Winter & Spring & Summer & Fall \\
\hline 2012 & 1 Dec 2011 - & 10 March 2012 - & 01 May 2012 - & 1 Sep 2012 - \\
& 9 March 2012 & 30 Apr 2012 & 31 Aug 2012 & 30 Nov 2012 \\
2013 & 1 Dec 2012 - & 31 March 2013 - & 13 Jun 2013 - & 1 Sep 2013 - \\
& 30 March 2013 & 12 Jun 2013 & 31 Aug 2013 & 30 Nov 2013 \\
2014 & 1 Dec 2013 - & 2 April 2014 - & 23 Jun 2014 - & 1 Sep 2013 - \\
& 1 April 2014 & 22 Jun 2014 & 31 Aug 2014 & 30 Nov 2013 \\
\hline
\end{tabular}

